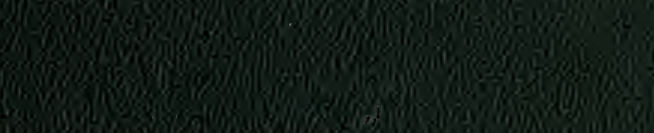

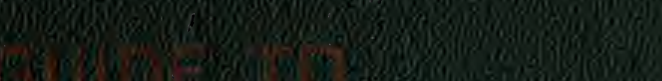
ongiving

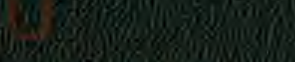
6.

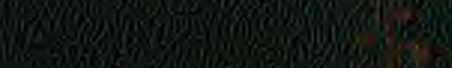




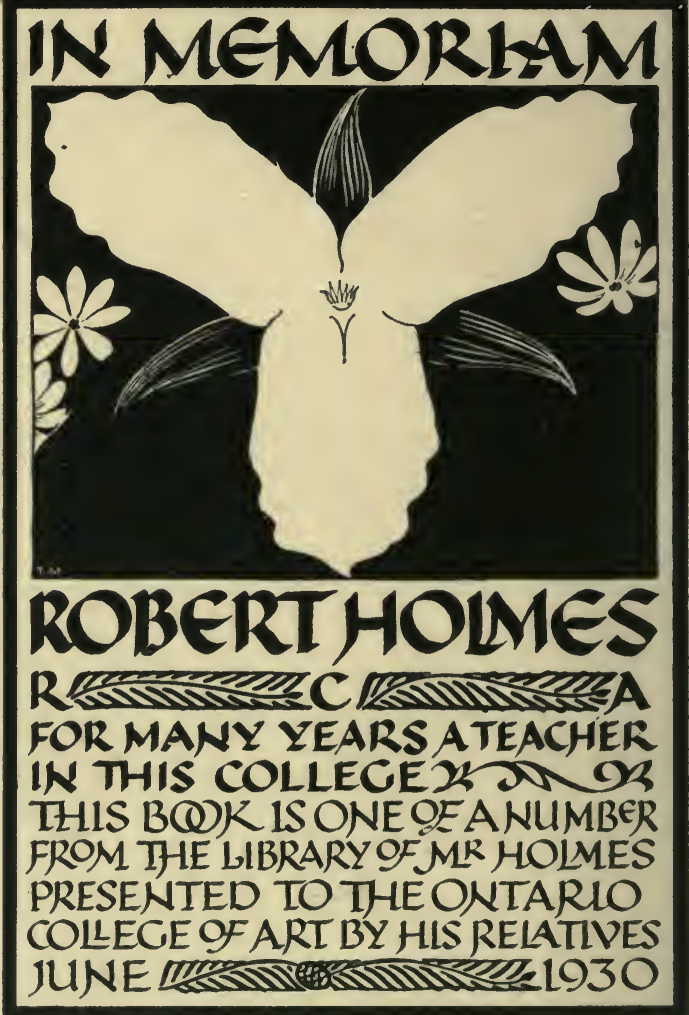






\title{
A GUIDE TO THE WILD FLOWERS
}

East of the Mississippi and north of Virginia

\author{
BY \\ NORMAN TAYLOR \\ CURATOR, BROOKLYN BOTANIC GARDEN
}

\begin{abstract}
With 520 illustrations from drawings by Dorothy N. Doner, Alice Earle Hyde and Bertha F. Taylor
\end{abstract}

\section{ONTARIO COLLEGE OF ART 100 MCCAUL ST. TORONTO 2B, ONTARIO}

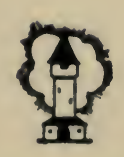

NEW YORK

GREENBERG, PUBLISHER 
Copyright 1928 by

GREENBERG, PUBLISHER, INC.

737

MANUFACTURED IN THE UNITED STATES OF AMERICA

BY THE VAIL-BALLOU PRESS, INC., BINGHAMTON, $N, Y$, 


\section{CONTENTS}

Preface • . . . . . . . . . . . .

How to Use the Book . . . . . . . . . vii

The Main Groups of Wild Flowers . . . . $\mathrm{x}$

A Guide to the Wild Flowers . . . ‘ . . . I

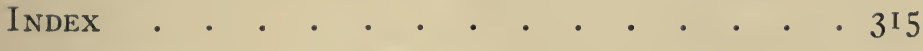

Finding List • • • • • • • • • • • • 343

Picture Glossary • • • . • . . . . 343 



\section{PREFACE}

This book is for those to whom it is difficult, or tedious, or perhaps impossible, to find wild flowers in technical works, and irritating not to find them in "How to Know" books.

It includes all the more conspicuous wild flowers that grow north of Virginia, and east of the Mississippi, except the grasses, sedges, and rare or technical species not likely to be interesting to the amateur. Professional botanists have several ways of sorting this mass of species into plant families, but the present book ignores such technicalities, for the average nature-lover cares more about the identity of plants, than about the family of them.

The arrangement of the book is, therefore, quite different from the current manuals. In them the sequence of plant families is obligatory. Here simpler and more direct methods of identification are used.

Brooklyn Botanic Garden

Norman Taylor 



\section{HOW TO USE THE BOOK}

Turn at once to page $\mathrm{x}$. There are but nine main groups into which all the wild flowers in the book have been sorted. None of these are difficult to identify, but if you do not know them, the pictures and descriptions under each will soon make them familiar.

Taking a flower at random is perhaps the best way of learning how the book works,-say the Common Hepatica. Turning to page $\mathrm{x}$, it is obvious that Hepatica belongs to the "Plants with netted-veined leaves." Under this we find "Vines," which it obviously is not, and "Not vines," where it unquestionably must be. Under "not vines" there are three choices thus:

Flowers usually inconspicuous, etc. (Not true of Hepatica)

Flowers with obvious, separate, divided petals (It must be here)

Flowers with united petals, etc. (Not true of Hepatica)

Throughout the book you will be presented with two, or rarely as in this case, three alternatives, and by examining the plant in hand you can usually tell to which it belongs. Turn at once to the number referred to under "Flowers with separate, divided petals," which is No. 3I 3 . Under that number, after a brief description of the group, there are again two alternatives, and it is perfectly obvious that Hepatica belongs to "Leaves, if present, not insect-catching, usually normal." Under that category is one headed "Leaves present, not reduced to scales," which so obviously must include Hepatica that one naturally looks beneath it for further help in finding just where the plant does come. Here we must decide whether the "Leaves are exclusively basal," etc., or if "Some or all the leaves are on the stem." Clearly the leaves are all basal in Hepatica, which directs us to No. 492. Turning to that number, and of course ignoring all other numbers 
in the book for the moment, we find "Petals or colored sepals 5 or more," or "Petals 4." Hepatica is in the first of these which leads us to No. 496, and turning to that number we must again decide between two minor categories. Hepatica having obviously lobed leaves we know the end of our hunt is near, and by making one or two further decisions we come to the final one which reads "Petals none; petallike sepals 7-12-Hepatica No. 498." Turning finally to that number we find the description and picture of the flower, and learn, perhaps for the first time that Hepatica has no petals but only petal-like colored sepals.

While the technicalities have been reduced to bare bones, it should be remembered that there is no absolutely painless method of identifying wild flowers. For plants possess roots, stems, leaves, flowers, fruit and seed, and each of these is of different shape, and color, and texture, and it is upon these differences that their identification is based. If the reader does not know these parts, he can learn them in ten minutes from the picture glossary near the end of the book.

\section{Plant Names.}

One or sometimes two common names have been found for practically all the plants in the book. For those who may wish to know their Latin names these are also included, according to those used in Britton \& Brown's “Illustrated Flora of the Northern States and Canada." The other standard work on the flora of the region is the Seventh Edition of Gray's Manual, and wherever these two books differ both names have been included here, the Gray Manual name always in brackets.

\section{Cross-Referencing and the Finding List.}

While the flowers are not all arranged according to family, although this has been done in some cases, the value of knowing what other plants in the book belong to a particular family is unquestionable. This has been accomplished by a system of cross-referencing by numbers. These may be ig- 


\section{A GUIDE TO THE WILD FLOWERS ix}

nored by many users of the book, but often they will be of the greatest use in identifying related species.

Some readers will no doubt prefer to go directly to the Finding List at the end, as perhaps the easiest way to identify their plants. 


\section{THE MAIN GROUPS OF WILD FLOWERS}

Plants with parallel-veined leaves. Turn to no. (not page) .... 2 (includes nos. 2-185)

Plants with netted-veined leaves (includes nos. 186-925) which are divided thus :

Vines no. 187

(includes nos. 187-242)

Not vines.

Flowers usually inconspicuous; without petals ....... no. 244 (includes nos. 245-312)

Flowers with obvious, separate, divided petals (includes nos. 313-621) which are divided thus:

Flowers regular and symmetrical.

Flowers not arranged as in the Carrot Family .... 110. 313 (includes nos. 313-525)

Flowers arranged as in the Carrot Family ....... no. 526 (includes nos. 526-555)

Flowers irregular and unsymmetrical, often pea-like, or violetlike ............................... no. 556 (includes nos. 556-621)

Flowers with united petals that form some sort of a tube or bell-shaped corolla, or at any rate united (includes nos. 622925) which are divided thus:

Flowers not in heads, as in the Daisy Family ...... no. 622 (includes nos. 622-808)

The Daisy Family ..................... no. 809

(includes nos. 809-925)

Aquatic or water plants $\ldots \ldots \ldots \ldots \ldots \ldots \ldots \ldots \ldots \ldots$ no. 926 


\section{A GUIDE TO THE WILD FLOWERS}

T $\mathrm{T}$ is well to distinguish three different sorts of herbs: $\mathbf{I}$.

Those whose roots persist from year to year, conse1 quently perennials, such as asters and goldenrods, and hundreds of others; 2 . Those whose roots live only two years, consequently biennials, like the fringed gentian, and of which there are only a few; and 3 . Those which die wholly at the end of one season, consequently anmuals, relying entirely upon their seeds for perpetuation, as do many of our common weeds.

Herbs are not really ever woody, although some have stiff stems which suggest it, such as the marshmallow, and some loosestrifes. Actually none of them produce buds that winter over above ground, as all shrubs and trees do, but die down to the ground, below which their growing parts are safely tucked away from the cold (perennials and biennials), or leave to the hazard of seeds, their chance of survival, as must all annuals.

Quite different characteristics must be adopted to distinguish herbs, than are found useful for other plants.

While nearly all herbs grow on land or in swamps, bogs, meadows, or marshes, or in the water, some are true aquatic plants, that float or live submerged beneath the surface. Like the water lily, some are beautifully fragrant or colored; others, like the legendary Vallisneria with its stark little tale of tragedy, are always submerged. It will be convenient to separate these water plants from all others, so that our primary division of the herbs will be thus: 
Floating or submerged aquatic plants ...............no. 926. Herbs of dry land, meadows, swamps, bogs, or marshes; if in the water, never submerged or floating aquatics .......no. I

No. I

Herbs of dry land, meadows, swamps, bogs or marshes; never submerged or floating aquatics.

This group, of course, comprises the bulk of all our herbs. Fortunately for purposes of identification there is one great structural difference that divides all these plants into two great classes. The characters given below are merely surface indications of profound differences in the structure and evolutionary history of these two great groups of herbs. These differences must be understood before it is possible to go farther in the identification of any particular species.

All these herbs, then, are divided thus:

With the veins of the leaf not parallel, but in some sort of a network, the parts of the flower (petals, etc.) in 4's or 5's, or multiples of these, not in 3 's; the sprouting seeds always with 2 seed leaves (exceptions noted at no. 186) ......no. 186

With the veins of the leaf parallel; the parts of the flower in 3 's, or multiples of 3 ; the sprouting seeds always with I seed leaf (exceptions noted at no. 2) .............. no. 2

\title{
No. 2 \\ Herbs with Parallel-Veined Leaves
}

\author{
(Nos. 2-185.) \\ (Monocotyledonae).
}

These herbs have parallel veined leaves, the veins or nerves usually with no side branching. Quite often the plant is without a true stem, both the flower and leaf stalks arising from the ground. Others, however, have a true stem. In many, the leaves are without marginal teeth, but sometimes these are present in neighboring species. In one sort, Asparagus (no. 99) there are no leaves. The wake-robins, or trilliums (no. 64), the jack-in-the-pulpit, and its cousins (no. 26), and one of the Water-plantain family (no. II), break all the rules by having leaves that are not parallel-veined, but they are included here, as exceptions, because their other characteristics 
are with the rest of this group. The false mermaid has only three petals, but is nevertheless classed with other plants (see no. 382 ).

The parts of the flower, such as the petals, etc., are nearly always in 3 's, or in multiples of 3 , the only exception being the False lily of the valley (no. 85) where they are in 4's. Besides their structural differences these herbs always sprout with a single seed leaf appearing above ground, hence their group name of MONOCOTYLEDONAE, while all other herbs always thrust two seed leaves above ground at germination, and are consequently called DICOTYLEDONAE.

Familiar examples of these two great groups of herbs are in the present series (Monocotyledonae), corn, Lily of the valley, Iris, Ladies' slipper, Gladiolus, and in the tropics, all the palms. Grasses and sedges would come in here, if they were admitted into this book. The other large group (Dicotyledonae) with netted-veined leaves, contains all other herbs, such as the Daisy, Buttercup, Violet, Thistle, Mint, and hundreds of others.

Look, also among the plantains, No. 273, and at Painted Cup, No. 626, for plants treated at those numbers, although they have parallel-veined leaves.

This first group, with parallel-veined leaves, and parts of the flower in 3 's, is divided thus:

Individual flowers not minute, the petals well developed, and often showy .......................... no. 33

Individual flowers minute, the petals often wanting, never showy (except in the Water-plantain Family, No. 6), in various kinds of clusters *

* The flower clusters in this group of plants are often made up of hundreds of tiny flowers. Each individual flower is usually too small to attract general notice, but the clusters in which they are crowded are familiar enough. Common examples are the Cat-tail, No. 4, where the flower is reduced to a few mere bristles (see Fig. 4), and the Bur-reeds, Nos. $16-18$, where the "bur" is made up of scores of tiny flowers with scale-like parts, (see Figs. 16 and 18). Notice carefully the distinction between the flozer which may be too inconspicuous to attract notice and the flower-cluster which is often quite striking. 


\section{A GUIDE TO THE WILD FLOWERS}

Flowers in a compact head; the yellow petals from between tightly overlapping scales, (see Figs. 23 and 25) ... Yelloweyed Grass no. 22

Flowers arranged as in Figs. 27-3I, or in some modification of it (see Figs. 27-3I ) ..... Jack-in-the-Pulpit Family no. 26 Flowers never yellow, nor arranged in clusters, such as the Jack-in-the-pulpit, and its relatives; usually but not always swamp or bog plants

Flowers in compact finger-shape clusters .... Cat-tail no. 3 Flowers not so

Flowers relatively large, white ... Water-plantain Family no. 6

Flowers small, arranged in various kinds of clusters. Flower-clusters globe-shaped

Flower-clusters terminal, solitary, (see Fig. I3) ....

Pipe-worts no. I2

Flower-cluster not terminal, nor solitary, (see Figs. I6 and I8) ................ Bur-reeds no. I5 Flower-clusters not globe-shaped ...... Arrow grass Family no. 19

\section{CAT-TAIL. TYPHA.}

Upright marsh perennials with long sword-shaped leaves and minute bristle-like flower crowded into a dense spikelike golden-brown cluster, finger-shaped. (Typhaceac.) Often forming immense cat-tail marshes, where nothing else grows for thousands of acres.

Leaves usually over $1 / 2$ in. wide, the flower-cluster continuous.

4. Cat-tail. Typha latifolia. Up to $6 \mathrm{ft}$. high and usually growing in dense colonies. Leaves distinctly striped. Flower clusters about $I$ in. thick and 4-12 in. long. July. Throughout North America. Fig. 4.

Leaves usually less than $T / 2$ in. wide, the flower-cluster divided into an upper and lower part, which is not continuous.

5. Narrow-Leaved Cat-Tail. Typha angustifolia. Similar to the preceding but with narrower leaves and an interrupted flower-cluster. July. Nova Scotia to Florida, along the coast. Scattered and rare inland. 

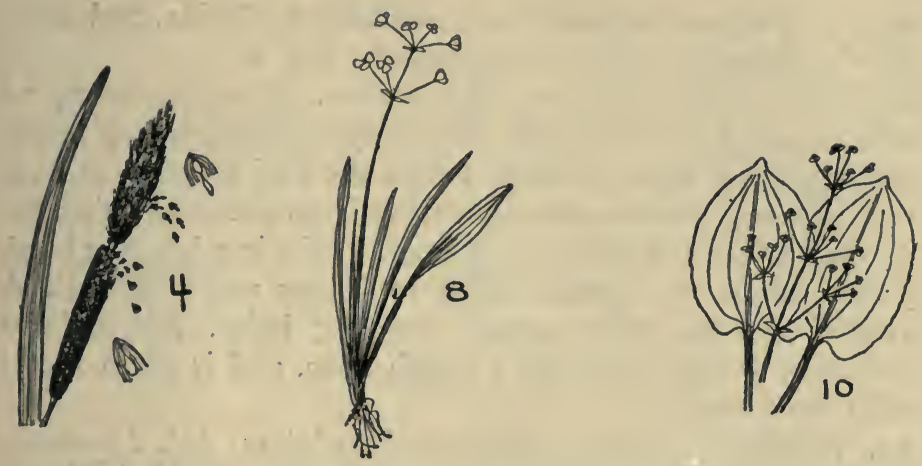

6. WATER-PLANTAIN FAMILY. ALISMACEAE.

Marsh or swamp plants with basal, usually sheathing leaves and (in some species) white flowers followed by dry fruits in round compact clusters. Petals 3 , white. In some species the leaves are not parallel-veined, see especially No. II.

Leaves without much distinction between blade and stalk.

Plant $2-6$ in. high; a salt-marsh

plant ............... Narrow-leaved Arrowhead no. 7

Plant 6-24 in. high; a fresh-water

plant ................. Grass-leaved Arrowhead no. 8

Leaves with a well developed, often arrow-shaped blade, and

a leaf stalk.

Leaf-blades not arrowhead-shaped.

Petals about $1 / 4$ in. long; fruit-heads about $1 / 3$ in. in diame-

ter; leaves heart shaped at base ........ Bur Head no. 9

Petals and fruit-heads much smaller, leaves not usually heart shaped at base ............ Water-plantain no. Io

Leaf-blades arrowhead-shaped, usually

large...$\ldots \ldots \ldots \ldots \ldots \ldots \ldots$. Arrow-head no. II

7. Narrow-leaved Arrow-head. Sagittaria subulata. A plant of the salt marshes, rarely more than 5 in. high. Leaves without much or any distinction between blade and leafstalk, I-3 in. long. Flowers white, nearly $1 / 2$ in. broad, usually in clusters of 3. August. Conn. to Florida, and Alabama.

8. Grass-leaved Arrow-head. Sagittaria graminea. Somewhat similar but much larger and found only in fresh water marshes. Leaves 3-12 in. long, the blade, when developed, 
with $3-5$ veins. August. Newfoundland to Florida, and westward. Young growth often purplish. Fig. 8.

9. BUR HEAD. Echinodorus cordifolius. An erect swamp of ditch plant. Leaves variable, but always stalked, mostly heartshaped at the base. In some forms the leaf is acute at both ends. Flower clusters several, arising from the same point, the 3 petals white and about $1 / 4$ in. long. Fruits in a bur-like head. June. Illinois to Florida, west to Texas and Missouri. A related species, with almost creeping habit, Echinodorus radicans, differs in having a rough stem, and is often found with the former.

ro. Water-plantain. Alisma subcordatum. (A. Plantagoaquatica.) Swamp or marsh plant of very variable habit. In youth, all the leaves may be floating and acute at both ends, in age, they are erect, stalked, usually oval, and with $5-7$ veins. Flowers numerous in scattered clusters, the white petals not over $1 / 8$ in. long or wide. The flower cluster in mature specimens usually much over-topping the leaves. Summer. New England to Florida and westward. Fig. Io. II. Arrow-head. Sagittaria latifolia. The commonest of a group of many species, distinguished by technical characters. Leaves stalked, very variable, nearly always arrowheadshaped, but the basal lobes sometimes broad as in the Elephant-ears, or narrow or slender. Flowers $I-1 / 2$ in. wide, with 3 showy white petals. Fruits in globe-like clusters. Summer. Throughout North America. Fig. II. A related species, Sagittaria pubescens, has hairy leaves and stems and is found from Nova Scotia to Penn., and westward.

\section{PIPEWORTS. ERIOCAULON.}

Swamp or bog plants with slender, grass-like leaves and compact button-like woolly heads of tiny white flowers on long basal stalks. The stalk is enclosed by a tight sheath which surrounds its lower part. (Eriocaulaceae.)

Leaves as long as the sheaths of the flower stalk.

13. PIPEWORT. Eriocaulon septangulare. Leaves all basal, not over 4 in. long, with $3^{-8}$ veins. Flower stalks, I- 8 in. high, 

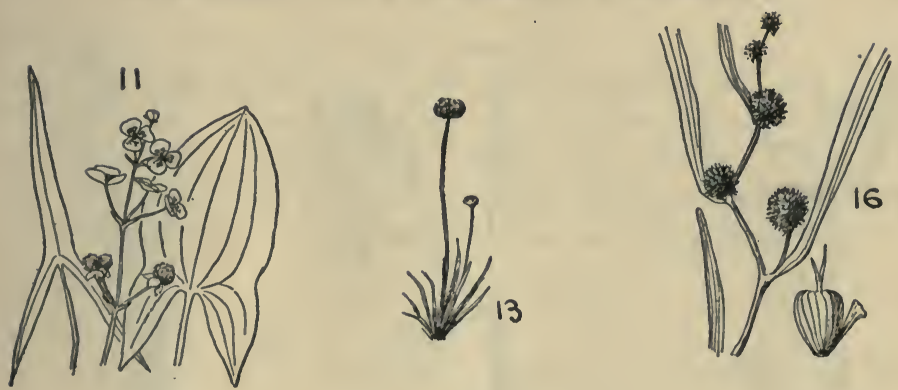

twisted, the heads almost $1 / 4$ in. in diameter. Summer. Newfoundland to Florida, and westward. Very common along the sandy edges of ponds and bogs. Fig. I3.

Leaves much longer than the sheaths of the flower stalk.

14. Pipewort. Eriocaulon decangulare. Leaves 6-20 in. long, with many veins. Flower stalks $\mathrm{I}-3 \mathrm{ft}$. high, the heads about $1 / 2$ in. in diameter. Summer. Pine barren bogs of New Jersey, to Florida and Texas. Other species are known, some of them partly or wholly submerged.

\section{BUR-REEDS. SPARGANIUM.}

Marsh or swamp or water plants with basal sheathing linear leaves. Flowers small, greenish, in isolated globe-like heads, without petals, followed by an almost prickly, burlike fruit-cluster. Flower stalks not sheathed as in the Pipeworts. (Sparganiaccae.) Twelve species are found in our range of which the following are the best known:

Stems 3-8 ft. high; fruit burs about $\mathrm{I}$ in. in diameter .. Burreed no. 16

Stem slıorter; fruit burs about $1 / 2 \mathrm{in}$. in diameter

Stalks of flower heads unbranched ....... Bur-reed no. I7 Stalks of flower heads branched, appearing zig-

zag ............................ Bur-reed no. 18 16. BUR-REED. Sparganium curycarpum. Stem stout, branched. Leaves flat or slightly ridged beneath, 3-5 ft. long. 

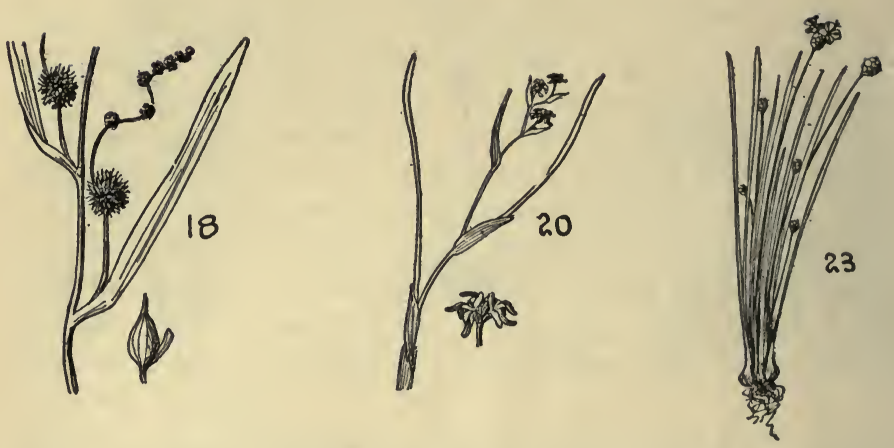

Flower heads about $\mathrm{I}-\mathrm{I} \mathrm{I} / 2$ in. in diameter isolated on branched stalks. Fruit burs stiff and almost prickly, about $I$ in. in diameter. Summer. Newfoundland to Florida, and westward. Often growing in the water. Fig. I6.

17. BUR-REED. Sparganium angustifolium. Stems $1 / 2-\mathrm{I} f \mathrm{ft}$. long, sometimes nearly floating. Leaves narrow, less than $1 / 4$ in. wide, not ridged on the back. Fruit-burs $3 / 4$ in. in diameter, on a simple, unbranched stalk. Summer. Newfoundland to Conn., and Penn., and westward.

I8. BUR-REED. Sparganium androcladum. (S. americanum androcladum.) Stems $\mathrm{I}-3 \mathrm{~T} / 2 \mathrm{ft}$. high. Much like the two preceding, but with smaller fruit-burs than the first and branched zig-zag stalks to the flower clusters. ummer. Newfoundland to Florida, and westward. Fig. I8.

\section{ARROW-GRASS FAMILY. SCHEUCHZERI- $A C E A E$.}

Marsh or bog plants with narrow grass-like leaves, and small flowers that lack true petals, arranged in spikes but never in globe-like clusters. Flowers and fruits commonly on short stalks. 


\section{A GUIDE TO THE WILD FLOWERS}

Stem leafy; flowers not very numerous.

20. Bog ARrow-Grass. Scheuchzeria palustris. A bog plant with leaves $4^{-18}$ in. long, the upper stem leaves much reduced in size. Flowers few, white, in a loose cluster, the stalklets spreading. Fruit about $1 / 8$ in. long. Labrador to New Jersey, and westward, mostly in cold northern bogs. August. Fig. 20.

Stems not leafy, the leaves all basal; flowers many, in a slender elongated, naked spike.

21. ARROW-GRASS. Triglochin maritima. Usually in salt marshes in the east, in fresh water westward. Leaves less than $1 / 8$ in. wide, often nearly round in cross section. Flower cluster slender, about $\mathrm{I}_{5}$ in. long, the small ( $1 / 8$ in.) whitish flowers on short stalks. Summer. North Temperate regions generally. A related species, Triglochin palustris, grows in bogs and has shorter leaves. It is found from Labrador to New York, and westward. Also in Europe and Asia.

\section{YELLOW-EYED GRASS. FLOWERING RUSH. XYRIS.}

Slender bog or swamp plants with flat, grass-like leaves. Flowers always yellow, in small terminal heads, composed of numerous over-lapping brownish scales through the upper ones of which the flowers emerge. (Xyridaceae.) Several species are known, of which the following are commonest:

Plants bulbous-thickened at the base

Leaves straight or slightly

twisted .............. Yellow Flowering Rush no. 23 Leaves conspicuously spirally

twisted .................. Yellow-eyed Grass no. 24

Plants not bulbous-thickened at the

base ..................... Yellow-eyed Grass no. 25

23. Yellow Fiowering Rush. Xyris flcxuosa. From 4-18 in. tall. Leaves flat, $I-6$ in. long, less than $1 / 8$ in. wide, sometimes slightly twisted, when old. Flower heads globe-likeoblong, about $1 / 4$ in. long; the expanded flower about $1 / 4$ in. in, diameter. August. Maine to Georgia, and westward, mostly in open bogs and meadows. Fig. 23. 

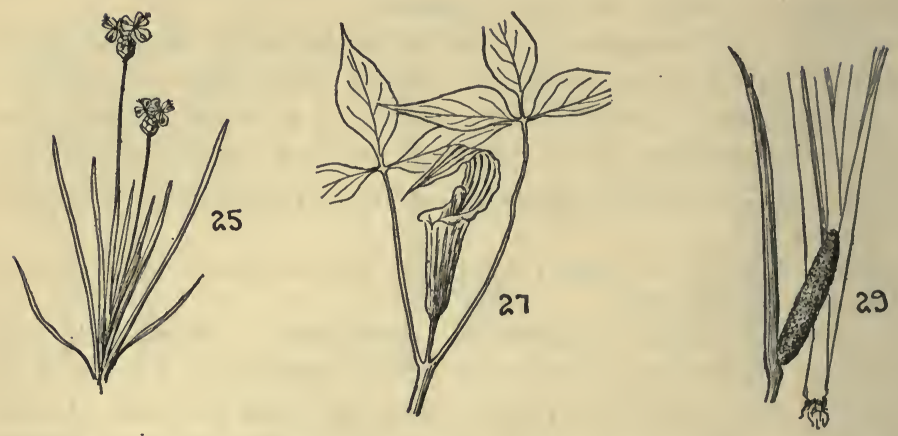

24. Yellow-eyed Grass. Xyris arenicola. Both the stalk of the flower head and the leaves conspicuously spirally-twisted. Leaves narrow, blackish toward the base, mostly shorter than the flower stalk. Flower heads oblong, or somewhat cylindric, $1 / 2-I$ in. long. July. Southern New Jersey to the Gulf ; mostly in pine barren bogs.

25. Yellow-eyed Grass. Xyris caroliniana. Not bulbousthickened at the base, I-2 ft. high. Leaves flat or slightly twisted, 4-12 in. long, often nearly $1 / 4$ in. wide. Flower heads nearly oval, about $1 / 2$ in. long. July. New England to Florida and Louisiana, mainly near the coast. Fig. 25.

26. JACK-IN-THE-PULPIT FAMILY. ARACEAE.

Herbaceous and even fleshy plants with simple or compound leaves. In some kinds, such as Jack-in-the-pulpit, the veins are not parallel. Usually developing a thick underground rootstock. Flowers minute, almost microscopic, closely crowded around a stalk (spadix), the latter surrounded by a cup-like or hooded organ (spathe), see Fig. 27 , or this sometimes a mere leaf-like appendage of the flower cluster, see Figs. 29 and 31. Fruit a berry, brightly colored. See the Picture Glossary for a cross section of a Jack-in-the-pulpit.

Leaves compound or divided

Leaflets 3 ; berries bright red ..... Jack-in-the-pulpit no. 27 Leaf divided into $5-17$ segments; berries orange 
red Leaves simple and undivided

Leaves long and narrow, sword-shaped .. Calamus Root no. 29 Leaves not so

Spathe completely surrounding the spadix; leaves arrowhead-shaped ................... Arrow-arum no. 30

Spathe only partially surrounding the spadix; leaves heartshaped at the base

Leaves $\mathrm{I}^{\mathrm{T} / 2-4}$ in. wide, appearing before or with the flower ............... Water Arum no. 3I Leaves 9-14 in. wide, appearing after the flower ................. Skunk-Cabbage no. 32

27. JACK-IN-The-PUlpit. Arisaema triphyllum. Nearly erect, I-3 ft. high. Leaves only I or 2 , composed of three oval leaflets, pointed at both ends and inequilateral at the base. Spadix with the flowers mostly at the base, 2-3 in. long, slightly thicker toward the top, surrounded by the green or purple-striped spathe. Berries red, nearly $1 / 2$ in. in diameter. May. Nova Scotia to Florida, and westward. Fig. 27. Forms with a uniformly thickened spadix have been distinguished as Arisaema pusillum, and another with a fluted spathe as Arisacma Stewardsonii. The latter is rare.

28. Green Dragon. Arisaema Dracontium. Leaves mostly only I, simple, but divided into $5^{-17}$ oblong segments, pointed at the tip. Spadix bearing flowers at the base, the naked tip often protruding $I-7$ in. beyond the tubular, but not hooded spathe. Berries orange-yellow. May. Maine to Florida, and westward. Not on Long Island, N. Y., nor in the pine barrens of New Jersey.

29. Calamus Root. Acorus Calamus. Leaves narrow, sword shaped, 2-6 ft. high, with roughened margins and prominent mid-vein. Spadix $2-3$ in. long crowded with flowers, the spathe a narrow leaf-like appendage, often projecting much beyond it. Fruit a gelatinous berry. Often forming dense growths in wet places. Nova Scotia to Louisiana and westward. June. Fig. 29. Also known as Sweet Flag.

30. Arrow-ARUM. Peltandra virginica. A coarse marsh plant, often growing in open water, with arrowhead-shaped leaves often 25 in. long, usually smaller. Spadix long-stalked, often turning downward at maturity, 3-6 in. long, en- 

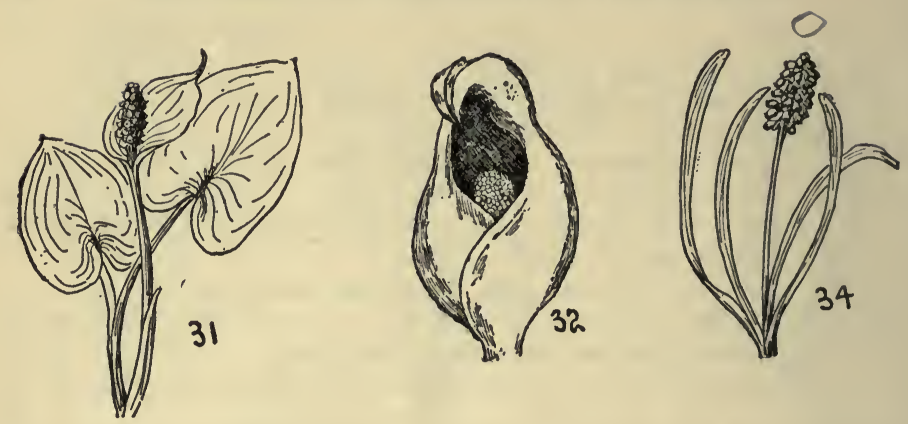

veloped in a sharp-pointed green spathe. Berries green. June. Maine and Ontario to Florida and westward.

3r. Water Arum. Calla palustris. Slender bog plant, the leaves heart-shaped at the base, scarcely 4 in. wide on stalks 4-8 in. long. Spadix I in. long on stalk about equalling the leaf-stalk. Spathe $I-2^{1 / 2}$ in. long, abruptly narrowed at the tip. Berries red, separate. Nova Scotia to New Jersey and Penn., west to Wisconsin and Iowa. Not known from Long Island, or coastal New Jersey. Fig. 3I.

32. Skunk Cabbage. Spathyema foetida. (Symplocarpus foetidus). Leaves many, $\mathrm{I}-2 \mathrm{I} / 2 \mathrm{ft}$. long, half as wide, appearing after the evil-smelling flowers. Spathe 3-5 in. long, brownish, yellow, or purplish. Spadix I in. long. Berries apparently fused. March. Nova Scotia to North Carolina, and westward. Fig. 32.

33. Individual flowers not minute, the petals well developed and often showy. (Nos. 34-185.)

Flowers very irregular and unsymmetrical (see

Figs. 134-184) $\ldots \ldots \ldots$... Orchids and Pickerel-weed no. 133

Flowers regular and symmetrical (in the Day-flower, no. 51, there are three blue petals, two large and one small).

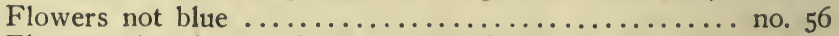

Flowers blue (except in the Yellow Flag, No. 39) 


\section{A GUIDE TO THE WILD FLOWERS}

Flowers with a leaf-like spathe below them (see Figs.

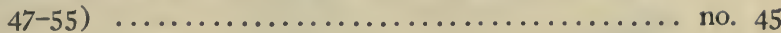

Flowers not so

Petals distinct, or nearly so ............... no. 36

Petals united to form a tube

Flowers small, in spike-like clus-

ters ................... Grape Hyacinth no. 34

Flowers at least $1 / 2$ in. long, in

loose clusters .............. Plaintain Lily no. 35

\section{GRAPE HYACINTH. MUSCARI.}

Low bulbous herb with fleshy leaves with parallel margins. Flowers small, in spike-like clusters, followed by a dry pod. (Liliaccae.)

Grape Hyacinth. Muscari botryoides. From 4 to io in. high. Leaves erect, not more than $1 / 4$ in. wide, grooved. Flower cluster about $I^{1} / 2$ in. long, the flowers nearly round or urn-shaped, tubular, and with 6 tiny teeth, scarcely $1 / 2$ in. long, blue. May. New Hampshire to Ohio and Virginia. Native of Europe. Fig. 34. Related to it is Muscari racemosum, with recurved leaves, and longer, oblong flowers, which is found from Conn. to Virginia, and is also a native of Europe.

\section{PLANTAIN LILY. NIOBE.}

Herbs, forming large masses. Leaves all basal, stalked. Flowers in stalked clusters, tubular or funnel-shaped, the segments longer or shorter than the tube. Fruit a pod. (Liliaceae.) Several species are known.

Blue Plantain or Day Lily. Niobe cocrulea. Leaves long stalked, the blades $4-8$ in. long, oval, heart-shaped at base. Flowers pale blue, about $1 / 2$ in. long, in a loose raceme. Fruit drooping, about $1 / 2$ in. long. Spring. Much cultivated and sometimes escaping. Native of Eastern Asia. 

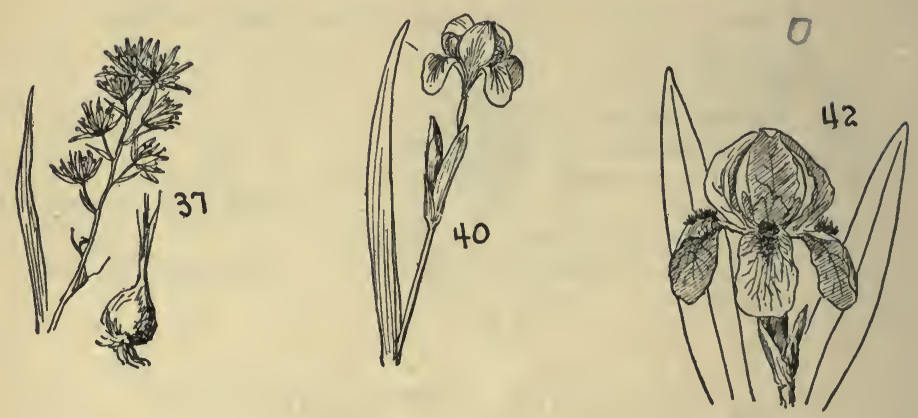

36. Petals distinct or nearly so.

Flowers in a wand-like cluster ......... Wild Hyacinth no. 37 Flowers solitary or a few together ............ Iris no. 38

\section{WILD HYACINTH. QUAMASIA.}

Bulbous herb with linear, mostly basal leaves. Flowers in a wand-like solitary raceme. Petals .6 , distinct, and spreading. Fruit a 3 -angled pod. Seeds shiny black. (Liliaccac.)

Wild Hyacinth. Quamasia hyacinthina. (Camassia esculcnta.) One to two feet tall, with slender leaves scarcely $1 / 4$ in. wide and somewhat shorter than the stalk of the flower cluster. Petals with 3-5 veins, blue, sometimes, but rarely, nearly white. Pod about $1 / 2$ in. thick. May. Penn. to Georgia, west to Minnesota and Texas, mostly in wet places. Fig. 37 .

\section{IRISES. IRIS.}

Not bulbous, but with rootstocks. Leaves long, linear or lance-shaped, folded and sheathing each other at the base. Flowers -sometimes solitary, or a few together, large and showy, long stalked. Flowers with three outer and large petals recurved and sometimes crested, and three smaller inner ones usually erect (see Figs. 40 and 42). Sometimes inner and outer series the same size. Pod angled. (Iridaccae.) 
Flowers yellow Yellow-flag no. 39

Flowers blue (sometimes with yellow markings)

Stems more than 6 in. tall; outer petals decidedly larger than inner

None of the petals crested (see Fig. 40).

Leaves $1 / 2-\mathrm{I}$ in. wide ................ Blue-flag no. 40 Leaves not much over $1 / 4$ in. wide ...... Blue-flag no. $4 \mathrm{I}$ Outer petals distinctly crested (see

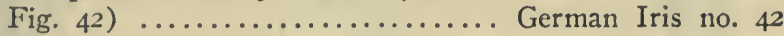

Stems scarcely 6 in. tall.

Outer petals crested; leaves not parallelmargined .................... Dwarf Iris no. 43

Petals not crested; leaves linear ........ Spring Iris no. 44 39. Yellow-FlaG. Iris Pseudacorus. Stems $\mathrm{I}-2 \mathrm{I} / 2 \mathrm{ft}$. tall. Leaves usually many, pale bluish green, a little more than $1 / 2$ in. wide. Flowers usually 2 or 3 together, large, not crested, the outer petals 2 in. long, yellow. Fruit $2-3$ in. long. June. New England to New York and New Jersey. Native of Europe.

40. BLUE-FLAG OR IRIS. Iris versicolor. Stems $I I / 2-2 I / 2$ ft. tall. Leaves from $1 / 2-I$ in. wide. Flowers not crested, blue or bluish-violet, marked with yellow or white. Fruit about $1 / 2$ in. long. June. Newfoundland to Florida, and westward. Fig. 40. This is the commonest species, and is found mostly in meadows.

41. Blue-Flag. Iris prismatica. Somewhat similar, but smaller in all its parts, with narrow nearly grass-like leaves, and paler flowers. May. Nova Scotia to Georgia, mostly near the coast, and in meadows.

42. German Iris. Iris germanica. Stems 2-3 ft. tall, often branched. Leaves $3 / 4-2$ in. wide, bluish-green. Flowers very showy, deep bluish-violet, 3-4 in. across. Outer petals strongly crested, the inner arching inward. June. Escaped from gardens in New England, and Virginia. Native of Europe. Fig. 42. Scores of garden forms with a variety of colors are known.

43. DwARF IRIS. Iris cristata. Stems scarcely 6 in. tall, the leaves lance-shaped, bright green, about 7 in. long. Flowers about $I \frac{1}{2}$ in. across, blue, the outer petals crested, not much longer than the inner ones. Fruit about $3 / 4$ in. long. In rich woods, Maryland to Indiana, and southward. Early spring. 

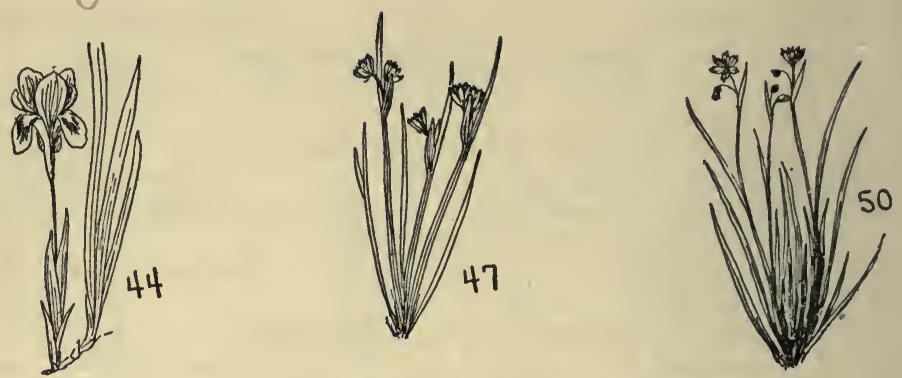

44. Spring Iris. Iris verna. Stems I-3 in. tall. Leaves 4-8 in. long, linear. Flowers somewhat similar to the pr-ceding, but not crested, and with yellow markings. In woods, Penn. to Kentucky, and southward. May. Fig. 44.

45. Flowers with a leaf-like spathe below them (see Figs. 47-55).

Leaves all basal, linear and grass-

like ........................ Blue-eyed Grass no. 46 Leaves not all basal; lanceolate or oval .... Spiderworts no. 5I

\section{BLUE-EYED GRASS. SISYRINCHIUM.}

Perennial grass-like herbs, with 2-edged or winged stems. Flowers small, the petals all of even size and distinct, usually dark blue, often with a fine-pointed tip beyond the otherwise blunt apex. Beneath the flowers is a leaf-like spathe (see Fig. 47). Fruit a small pod. (Iridaceae.) Many species are known of which the commonest are:

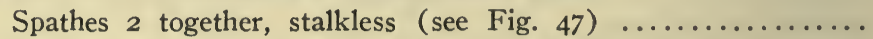

Spathes single, or if more than one, stalked (see Fig. 50)

Stems mostly unbranched ......... Blue-eyed Grass no. 48 Stems branched above

Plants fibrous toward the base ...... Blue-eyed Grass no. 49 Plants not fibrous towards the base .. Blue-eyed Grass no. 50 
47. Blue-eyed Grass. Sisyrinchium albidum. Scarcely $2 \mathrm{ft}$. tall, often bluish-green. Leaves half as high as the winged stems, scarcely $1 / 8$ in. wide, the edges often roughened. Flowers pale blue to whitish, not over $1 / 2$ in. wide. Spathes stalkless, in pairs. Pod nearly round, about $1 / 8$ in. diameter. May. Meadows. Ontario to N. Car. west to Wisconsin, Arkansas, and Mississippi, apparently introduced into Conn. and New York. Fig. 47.

48. Blue-eyed Grass. Sisyrinchium angustifolium. Similar but with the edges of the leaf always minutely roughened. Flowers deep violet-blue. Spathes solitary, or if more than one, always stalked. Stem nearly always unbranched. June. Meadows. Newfoundland to Virginia, and westward.

49. Blue-eyed Grass. Sisyrinchium arenicola. Stem erect, IO-20 in. tall, usually branched above, the whole plant turning dark in drying. Leaves green or bluish-green, fibrous at the base. Flowers numerous, deep violet-blue, nearly $1 / 2$ in. wide. Pod broadly oval, not quite $1 / 4$ in. thick. June-July. New England to N. Car., especially in coastal marshes.

50. Blue-Eyed Grass. Sisyrinchium graminoides ( $S$. gramineum.) Similar to the preceding, but not fibrous at the base, with wider leaves (up to $1 / 4$ in.), and larger in all its parts. Turning dark in drying. May. Nova Scotia to Florida, and westward. Our commonest species. Fig. 50. A salt marsh relative, Sisyrinchium atlanticum, differs in having the stem less prominently winged, and is found from Maine to Florida.

\section{5r. SPIDERWORTS. DAY-FLOWER. TRADESCANTIA. COMMELINA}

Leafy herbs with swollen joints and usually very fleeting flowers, in scanty clusters, or solitary, beneath which is a leaf-like veiny spathe, or in some species, a large leafy bract. (See Fig. 55.) Petals 3, always blue, in some species 2 larger and a smaller one. Fruit a dry pod. (Commelinaceae.)

With 2 large petals and a small one; spathe usually shell-shaped.

Margins of the spathe not joined

(see Fig. 52) ............... Common Day-flower no. 52 Margins of the spathe joined at the base (see 

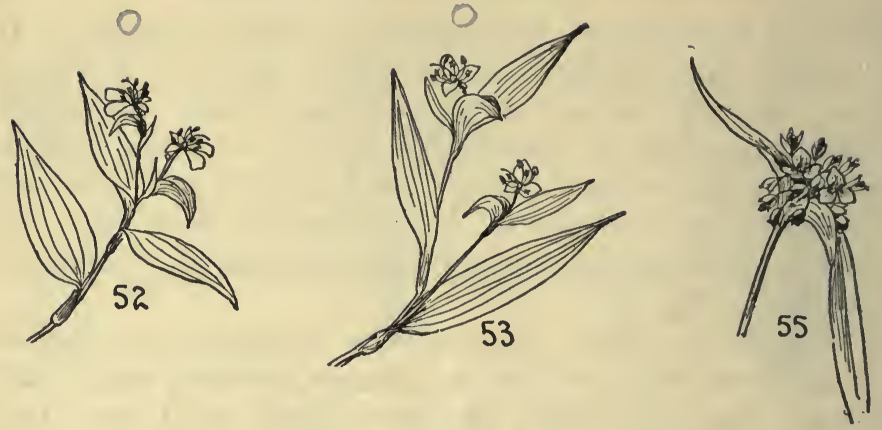

Fig. 53) $\ldots \ldots \ldots \ldots \ldots \ldots \ldots \ldots$. Day-flower no. 53 With all petals the same size; spathe long and leaf-like

Leaves bright green; flower stalks hairy .... Spiderwort no. 54 Leaves bluish-green; flower stalks not

hairy .......................... Spiderwort no. 55

52. Common Day-flower. Commelina communis. Stems fleshy but weak. Leaves lance-shaped or oblong, sharppointed at the tip, $2^{1} / 2^{-1}-2$ in. long. Spathes veiny, shellshaped, the margins free, the tip acute. Flower about $1 / 2$ in. wide, deep blue. Summer. Mostly in door yards and along roadsides. Mass. to Penn., perhaps native from Delaware to Florida. Fig. 52. A related species, Commelina mudiflora, differs in having spathes with a long drawn out tip, and is found from New Jersey to Florida, and west to Indiana. 53. DaY-Flower. Commelina virginica. Like the preceding, but the edges of the spathe united at the base to form a shell-like cup. Summer. Moist places from New York City to Florida, west to Illinois and Texas. Fig. 53.

54. Spiderwort. Tradescantia virginiana. 8-30 in. tall, and leafy. Leaves bright green, often nearly a foot long, $1 / 2-I$ in. wide. Spathe leaf-like, not shell-shaped, usually shorter and broader than the true leaves, just beneath the flower cluster. Flowers I-2 in. wide, blue or purplish-blue, the petals all the same size, and pointed. June-July. In woods. New York to Virginia, and westward; rather a rare plant eastward.

55. Spiderwort. Tradescantia reflexa. Somewhat similar to the preceding but with smaller flowers that are sometimes 
reddish, and with the flower stalks not hairy. Petals almost round, all the same size. Foliage bluish-green. Summer. Moist sand or clay. Ohio to Minn., Florida and Texas. Fig. 55 .

56. Flowers not blue, of various other colors. (Nos. $57-132$.) Twining vines ............................ no. 130

Plants not twining

Flowers I, or few, or many, always terminal, often in showy clusters much overtopping the leaves $\ldots \ldots \ldots \ldots \ldots$. no. 63

Flowers solitary or few, usually on a leafy stem, never in terminal clusters

Leaves reduced to scales; foliage

feathery ..................... Asparagus no. 99

Leaves normal

Petals separate; leaves broad or stems-clasping at the base ..................... Twisted Stalks no. 57

Petals united to form a tubular flower; leaves narrowed at the base ................ Solomon's Seal no. 60

\section{TWISTED STALKS. STREPTOPUS.}

Alternate-leaved, branching herbs with greenish or purplish flowers. Leaves stem-clasping, or with a broad base, many-veined. Flowers one or two together, on slender bent stalks, between or near the leaf bases. Petals separate, at least towards the recurved tips. Fruit a red berry. (Convallariaceae.)

Leaves stem-clasping, bluish-green; flowers greenish-white.

58. Twisted Stalk. Streptopus amplexifolius. From I-3 ft. high, the stems apparently somewhat twisted. Leaves $2-4 \frac{1}{2}$ in. long, acute at the tip, stem-clasping and heart shaped at the base. Flower stalks $\mathrm{I}-2$ in. long, I-2 flowered. Flowers scarcely $1 / 2$ in. long, the berry about the same size. June. In rich woods. Greenland to Alaska, south to No. Carolina, Ohio, Michigan and New Mexico, mostly in the mountains. Fig. 58 .

Leaves merely broad at the base, not stem-clasping, green; flowers purplish. 

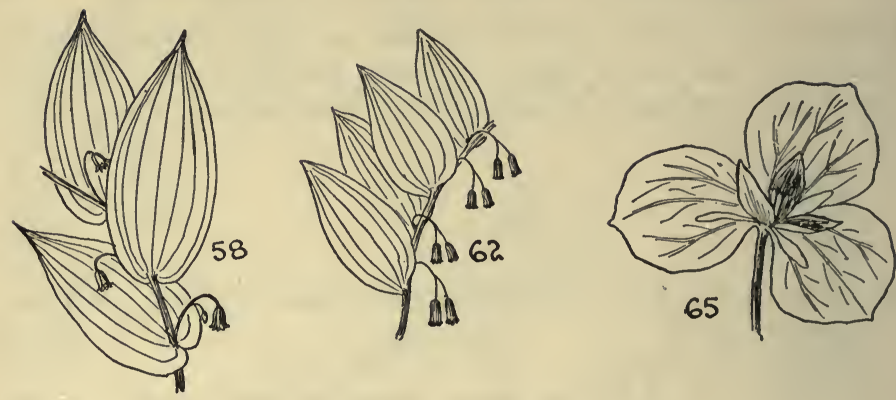

59. Twisted Stalk. Streptopus roseus. Somewhat similar to the preceding but differing in having smaller, green, leaves, and flower-stalks nearly always I-flowered. June. Rich woods. Newfoundland to Georgia, and westward, much more common than No. 58 .

\section{SOLOMON'S SEAL. POLYGONATUM.}

Herbs with arching simple stems, and alternate leaves. Flowers I-8 together, on slender stalks, always appearing from the bases of the leaves. Flowers tubular, with 6 short terminal lobes. Fruit a blue or black berry. (Convallariaceae.) Leaves hairy beneath.

6r. Solomon's Seal. Polygonatum biflorum. From 8-30 in. high, often with a zig-zag stem above. Leaves oval to lanceolate, narrowed at the base, 2-4 in. long, half as wide, hairy below, especially on the 3 veins. Flowers $\mathrm{I}-8$ together, usually 2 or 3 , about $1 / 2$ in. long, greenish or pinkish. Berry about $1 / 4$ in. in diameter. May. Woods and moist thickets. New Brunswick to Florida, west to Michigan, Kansas, etc.

Leaves smooth beneath.

62. Solomon's Sexl. Polygonatum commutatum. Similar to the preceding, but usually much taller and coarser leaved, and with the smooth leaves many-veined. June. Woods and moist thickets. New England to Georgia, and westward. Fig. 62. 
63. Flowers one or few, or many, always terminal, often in showy clusters much overtopping the leaves. (Nos. 64-I29.) (The Asparagus, No. 99, is an exception.)

Leaves long, often grass-like, with margins parallel, or nearly so

(Exceptions are given at No. 100) $\ldots . \ldots \ldots \ldots \ldots$ no. 100 Leaves never long or grass-like, often oval, not parallel-margined. Leaves not all terminal ....................... no. 72 Leaves.and solitary flowers both terminal .. Wake-robin no. 64

\section{WAKE-ROBIN. TRILLIUM.}

Showy herbs with 3 leaves in a terminal cluster, from which arises the solitary flower, which may or may not be stalked. Petals 3 , distinct, white, pink or purplish. Fruit a many-seeded berry. (Convallariaccae.) The flowers are variable as to color in some species, and the leaves are not parallelveined.

Flowers not stalked

Leaves not stalked .................. Wake-robin no. 65

Leaves stalked ............... Prairie Wake-robin no. 66

Flowers stalked.

Leaves I-2 in. long ....... Dwarf white Wake-robin no. 67 Leaves larger

Leaves not stalked, or if short-stalked, then narrowed at the base

Flowers usually white, $2-3 \frac{1}{2}$ in. wide. erect or nearly so ........... Showy Trillium no. 68

Flowers pink, whitish, or purple, smaller

Flowers on erect stalks, pinkish-

purple $\ldots . \ldots \ldots \ldots \ldots \ldots$.......... Birth-root no. 69

Flowers on recurved stalks, thus partly hidden by the leaves, pink or whitish .. Nodding Wake-robin no. 70 Leaves decidedly stalked, broad at the base ................... Painted Wake-rolin no. 7I 65. Wake-robin. Trillium sessilc. Not over 12 in. high. Leaves nearly oval, without stalks, $\mathrm{I} / 2-4$ in. long, sharp pointed. Flower stalkless, erect, purplish-green, $1 \mathrm{x} / 2-2 \mathrm{I} / 2$ in. wide, the petals spreading, sharp-pointed. Berry 6-angled, $1 / 2$ in. in diameter. Spring. Woods, Penn. to Fla. west to Ohio. Minn. etc. Fig. 65.

66. Prairie Wake-robin. Trillium recurvatum. From 7-15 


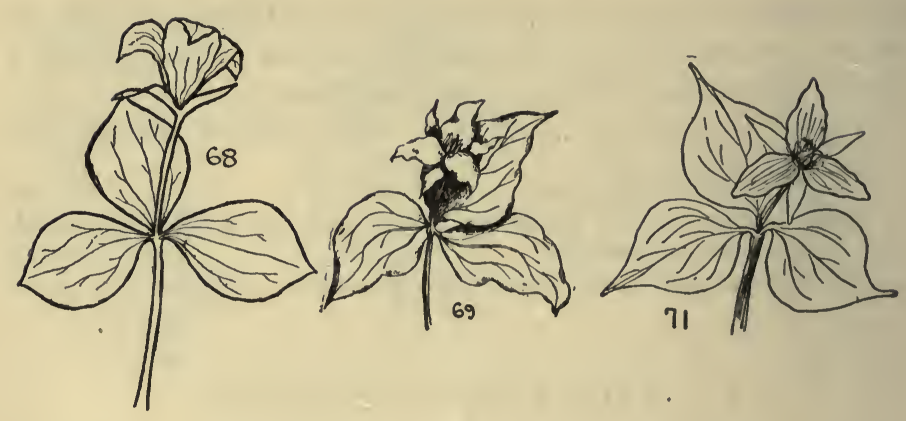

in. high. Leaves decidedly stalked, nearly oval, sharp-pointed at both ends, I-4 in. long. Flowers green, the petals nearly erect, $1 / 2-11 / 4$ in. long. Berry 6 -angled or winged. May. Ohio. to Miss. and westward, mostly in woods and thickets.

67. Dwarf White Wake-robin. Trillium nivale. Not over 7 in. high. Leaves oval or nearly round, I-2 in. long, stalked. Flowers white, stalked, oblong, or oval, about $3 / 4$ in. long. Berry nearly round, 3-lobed or angled. April. Woods, Penn. to Minn. south to Ky. and Neb.

68. Showy Trillium or Wake-Robin. Trillium grandiflorum. From 8-18 in. high. Leaves broadly oval, 2-6 in. long, stalkless. Flowers $2-3^{T} / 2$ in. wide, white, very showy, the erect or spreading prominently veined petals, I-2 in. long. Berry black, nearly round, somewhat 6-lobed, about I in. in diameter. June. In rich woods. Quebec to North Carolina, and westward, rare or wanting near the coast. The most striking of all the Trilliums. Fig. 68.

69. Birth Root, or Ill-scented Wake-robin. Trillium crectum. About I ft. high. Leaves broadly oval, sharp pointed at the tip, broad at the base, stalkless. Flowers on erect stalks often $2-4$ in. long. Petals narrow, spreading, purplish, pinkish or even whitish, rarely $3 / 4-\mathrm{I}^{\mathrm{T}} / 2$ in. long. Berry ovoid, slightly 6-lobed, and reddish-purple. May. Nova Scotia to Ontario, south to No. Car. and Tenn., nearly always in woods. Fig. 69.

70. Nodding Wake-robin. Trillium cermumm. From IO-20 in. tall. Leaves broadly oval, narrowed at both ends, I-2 


\section{A GUIDE TO THE WILD FLOWERS}

in. long, stalkless. Flowers on recurved stalks, whitish or pink, scarcely $I^{1} / 2$ in. wide. Berry ovoid, reddish purple, hanging. May. In woods. Newfoundland to Georgia, and westward.

7r. Painted Wake-robin. Trillium undulatum. Sometimes as much as $2 \mathrm{ft}$. high. Leaves oval, 3-7 in. long, about half as wide, long pointed at the tip, broad at the base and stalked. Flowers stalked, white, and purple-striped, about 2 in. wide. Berry 3 -angled, shining scarlet. May. Nova Scotia to Georgia, and westward, mostly in moist woods. Fig. $7 \mathrm{I}$.

72. Leaves not all terminal. (Nos. 73-98.)

Leaves all borne on the stem, (see Figs $8 \mathrm{I}-90$ ) ........ no. 80 Leaves nearly basal; plants practically stemless (see Figs. 74, $76,78)$

Flowers solitary ............... Dog's-tooth Violet no. 73

Flowers not solitary

Flowers racemose, the petals not

separate $\ldots \ldots \ldots \ldots \ldots \ldots \ldots$ Lily-of-the-Valley no. 76 Flowers not racemose, the petals distinct .. Clintonia no. 77

\section{DOG'S-TOOTH VIOLET. ERYTHRONIUM.}

Nearly stemless herbs with showy nodding flowers, but these often lacking for many years, and found only on plants at least three years old. Leaves basal. Flowers solitary, the petals separate, fruit a dry pod, oval or nearly so. (Liliaceae.) Flower yellow.

74. Dog's-tooth Violet, or Adder's-Tongue. Erythronium amcricanum. Leaves oblong, pointed at both ends, 3-8 in. long, about $1 / 3$ as wide, often brown mottled. Flower on a stalk as long as the leaves, the petals recurved, $3 / 4-1 \mathrm{I} / 2$ in. long. Pod $1 / 2-3 / 4$ in. long. April. Moist woods and thickets. Nova Scotia to Florida, and westward. Common. Fig. 74.

Flower white.

75. White Dog's-tnoth Violet, or Adder's-tongue. Erythronium albidum. Similar to the preceding in general aspect, 

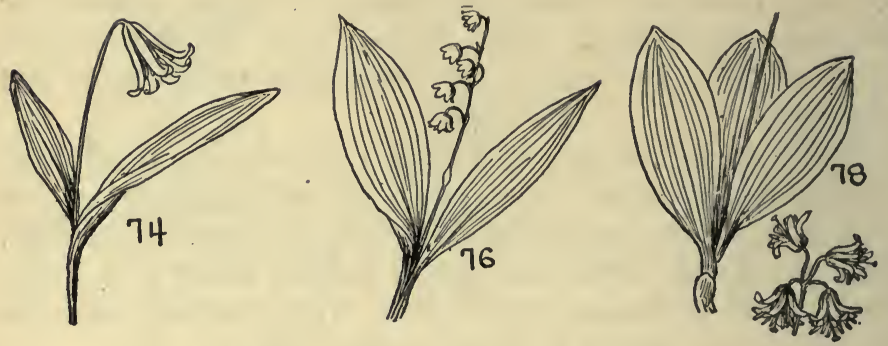

but with a white flower. April. Ontario to Georgia, and westward. Rare or wanting near the coast.

\section{LILY-OF-THE-VALLEY. CONVALLARIA.}

Nearly stemless herbs with 2 or 3 many-veined leaves, sheathing at the base. Flowers white, drooping, in an erect, often I-sided, raceme. Petals united to form a round or bellshaped flower. Fruit a pulpy berry. (Convallariaceae.) The only species is

Lily-OF-THe-Valley. Convallaria majalis. Leaves oblong or oval, pointed at both ends, $4-9$ in. long, about $1 / 3$ as wide. Flower cluster, $I-3 \frac{1}{2}$ in. long. Flowers about $1 / 4$ in. long. Berry about $1 / 4$ in. in diameter. May. Common in cultivation and often escaping in the north and east, but wild only in the mountains of Virginia and the Carolinas. Fig. 76.

\section{WILD LILY-OF-THE-VALLEY. CLINTONIA.}

Stemless herbs with basal sheathing leaves. Flower stalks as long as the leaves. Flowers in a cluster, the petals distinct, often spreading. Fruit an oval or round berry. (Convallariaceae.)

Flowers yellowish-green, nodding; plant smooth; berry blue. 78. Clintonia or Wild Lily-OF-the-Valley. Clintonia borealis. Leaves usually 3 , sometimes more or fewer, usually shorter than the stalk of the flower cluster. Flowers $3^{-6}$ in. 
a cluster, the individual flower-stalks not all arising from the same point. Berry oval. June. Rich cool woods. Newfoundland to No. Carolina, west to Manitoba and Wisconsin. Rare near the coast. Fig. 78 .

Flowers white, erect; plant hairy; berry black.

79. White Clintonia or Dog Plum. Clintonia umbellulata. Leaves inverted-oval, abruptly sharp-pointed at the tip, about as long as the stalk of the flower cluster. Clusters manyflowered, the individual flower-stalks all arising from the same point. Berry round. June. In woods. New York and New Jersey to Georgia and Tenn. Rare in most places, but common in the Allegany State Park, in western New York.

8o. Leaves all borne on the stem. (Nos. 8I-98.)

Three or more leaves arising from the same point on the stem (exceptions are two alternate-leaved Lilies with flowers at least $2 \frac{1}{2}$ in. long, Nos. 95 and 98$) \ldots \ldots \ldots \ldots \ldots$ no. 91

Leaves opposite or alternate, never more than 2 arising at the same point; flower not over $1 \frac{1}{2}$ in. long.

Flowers I or 2, rarely $3 \ldots \ldots$. Bellworts and Disporum no. 86 Flowers more numerous, in clusters

Leaves $6-12$ in. long, the flower cluster much branched ...................... Hellebore no. 8I

Leaves smaller, the flower cluster unbranched, or only slightly so

Parts of the flower in 6's; leaves not heart

shaped at the base ............... Spikenard no. 82

Parts of the flower in 4's; leaves heart shaped at the base ............... False Lily-of-the-Valley no. 85

\section{8i. HELLEBORE. VERATRUM.}

Tall coarse herbs with large, prominently-veined leaves. Flowers in a large branched cluster, much overtopping the leaves. Petals distinct and separate. Fruit a 3-lobed pod. (Melanthaccac.)

Hellebore or Indian Poke. Veratrum viride. Often 3-5 ft. tall. Leaves oval, sharp-pointed at the tip, sheathing 

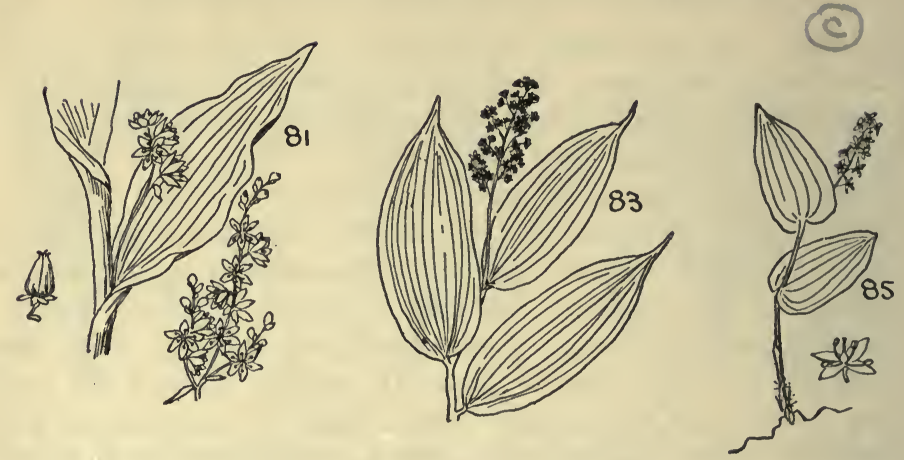

at the base, 6-12 in. long, diminishing toward the flower cluster, which is 8-30 in. long. Petals yellowish-green, nearly an inch long. Pod about $I$ in. long. June. New Brunswick to Georgia, west to Minnesota, mostly in wet or moist woods. Fig. 8I. A related species, $V$ cratrum $W$ oodii, with a smaller greenish purple flower is known from southern Indiana to Missouri.

\section{SPIKENARD. VAGNERA.}

Herbs with alternate leaves. Flower cluster simple and unbranched, or often slightly branched. Flowers small, greenish-white or white. Petals separate and distinct. Fruit a round berry. (Convallariaceae.)

Flowers numerous in an often branched cluster.

83. Spikenard or false Spikenard. Vagnera racemosa. (Smilacina raccmosa.) Stem I-3 ft. high, often angled. Leaves oblong or oval-oblong, 3-6 in. long, about half as wide, hairy beneath. Flower cluster I-4 in. long, the flowers scarcely $1 / 8$ in. wide. Berry red, purple spotted, fragrant. June. Nova Scotia to Georgia, and westward. Very common, and growing in a variety of situations. Fig. 83 .

Flowers few in a simple raceme.

84. Star-flowered Solomon's Senl. Vagnera stellata. (Smilacina stcllata.) Stem 8-18 in. high. Leaves slightly clasping, $2-4 \frac{1}{2}$ in. long, oblong-lance-shaped. Flower cluster 
I-2 in. long. Flowers larger than in the preceding. Berry green and black striped, or black. June. Sandy soil. Newfoundland to Virginia, and westward. A related species, Vagnera trifolia, differs in having only $2-4$ leaves and is found from Newfoundland to Conn. and Penn., west to Michigan, mostly in the richer soils of the mountains.

\section{FALSE LILY-OF-THE-VALLEY. UNIFOLIUM.}

Small slender herbs with leaves heart-shaped at the base. Flowers white, in a small terminal cluster, the petals and other parts of the flower in 4's. Fruit a round berry. (Convallariaceae.)

False Lily-of-The-Valley. Unifolium canadense. (Maianthemum canadense.) Not over 7 in. high, usually lower. Leaves mostly 2, sometimes I or 3 , oval, acute at the tip, heart-shaped at the base, I-3 in. long. Raceme manyflowered, $I-2$ in. long. Flowers about $1 / 12$ in. wide. Berry speckled, reddish, about $1 / 6$ in. in diameter. June. Newfoundland to Tenn., and westward. Common, and growing nearly always in considerable masses. Fig. 85 .

\section{BELLWORTS AND DISPORUM. UVULARIA AND DISPORUM.}

Slender herbs with alternate stalkless leaves. Flowers I or 2 , rarely 3 , terminal, the petals distinct, or partly united below. Fruit a berry or 3 -angled pod. (Convallariaccac.)

Leaves conspicuously stem-clasping, the stem passing through the blade of the leaf

Leaves bluish green and smooth ........... Bellwort no. 87

Leaves green and hairy beneath .............. Bellwort no. 88

Leaves merely stalkless, not stem-clasping.

Fruit a 3-angled pod; leaves equilateral, acute at each end ......

Fruit a pulpy berry; leaves inequilateral, rounded at the base $\ldots \ldots \ldots \ldots \ldots \ldots \ldots \ldots$. Disporum no. 90 

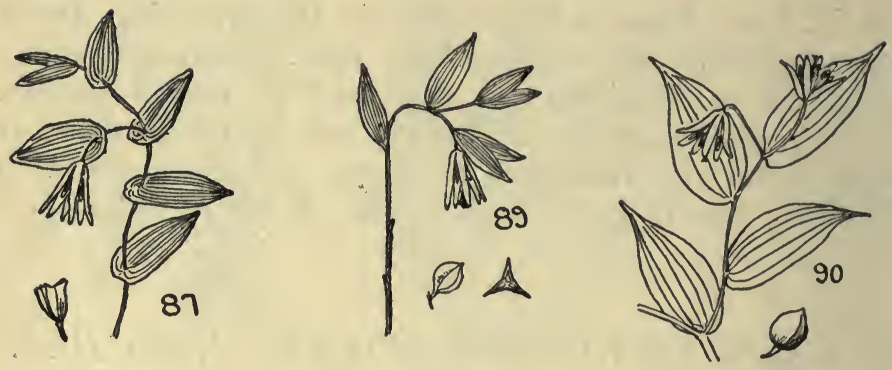

87. Bellwort. Uvularia perfoliata. Stem usually branched about the middle, $7-18$ in. tall. Leaves oval or oblong, strongly stem-clasping, 2-4 in. long, often smaller at flowering time, acute at the tip. Flower solitary, yellowish green, usually drooping. Petals about $\mathrm{I}$ in. long. Pod 3 -angled, slightly less than $1 / 2$ in. long. May. Quebec and Ontario to Florida and Mississippi, mostly in woods. Fig. 87.

88. Bellwort. Uvularia grandiflora. Similar to the preceding, but with larger, lemon-yellow flowers and with leaves that are hairy beneath. May. Rich woods. Quebec and Ontario to Georgia, and westward. Rare near the coast.

89. Bellwort. Uvularia sessilifolia. (Oakesia sessilifolia.) Usually not over I ft. high. Leaves oblong or oblong-lanceolate, $\mathrm{I}-2 \mathrm{I} / 2$ in. long, narrowed at each end. Flower solitary, terminal, but sometimes appearing not so, because of overtopping of adjacent foliage. Flower greenish-yellow, about $\mathrm{I}$ in. long. Pod sharply 3 -angled, about $\mathrm{I}$ in. long. May. In various situations. New Brunswick to Georgia, and westward. Fig. 89.

90. Disporum lanuginosum. No common name. Stem densely hairy, I-2 $1 / 2 \mathrm{ft}$. high. Leaves inequilateral, oval or lanceshaped, pointed at the tip, rounded at the base, 2-4 in. long. Flowers greenish, terminal, solitary, or more often 2 (rarely 3 ), together, the petals partly united at the base. Fruit a red pulpy berry about $1 / 2$ in. in diameter. May. Woods. Ontario and western New York to Georgia and Tenn., mostly in the mountains. Fig. 90. 

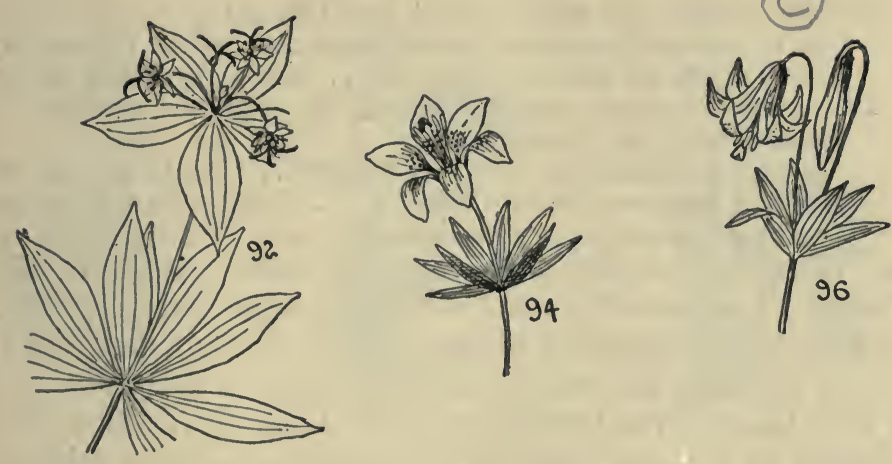

9I. Three or more leaves arising from the same point on the stem; leaves whorled. (Exceptions are two alternate-leaved Lilies, Nos. 95 and 98.)

Flowers never white (in our species) .......... Lilies no. 93 Flowers white $\ldots . \ldots \ldots \ldots \ldots \ldots \ldots$. Cucumber-root no. 92

\section{CUCUMBER-ROOT. MEDEOLA.}

Slender herb with simple, unbranched stem and whorled leaves (see Fig. 92) 4-10 in a whorl, the latter often distant. Leaves of the top-most whorl usually $3-5$. Flowers $2-9$ in a terminal cluster, white, their stalks of uneven length. Fruit a berry. (Convallariaccae.)

CUCUMBER-ROOT. Medcola virginiana. Usually less than $2 \mathrm{ft}$. tall. Leaves of the upper whorl I-2 in. long, about half as wide. Flowers about $1 / 2$ in. wide. Berry dark purple, a little less than $1 / 2$ in. in diameter. May. In woods. Nova Scotia to Florida, west to Minnesota and Tennessee. Fig. 92.

\section{LILIES. LILIUM.}

Usually tall herbs with clustered or alternate leaves and showy flowers in terminal clusters, or solitary. Flowers funnel-shaped, or bell-shaped. Petals separate, often recurved, never white in our species. Fruit a many seeded pod. (Liliaccae.) 
Flowers upright, the petals clawed (see Fig. 94)

Leaves nearly all clustered, lance-shaped .... Wood Lily no. 94

Leaves nearly all alternate, narrower .. Western Red Lily no. 95 Flowers not upright, usually drooping, the petals not clawed.

Leaves nearly all clustered

Leaves roughened on the veins beneath .. Canada Lily no. 96

Leaves quite smooth both sides ..... Turk's Cap Lily no. 97

Leaves all alternate; a garden escape ...... Tiger Lily no. 98 94. Wood Lily. Lilium philadelphicum. Stem $1 \mathrm{I} / 2-31 / 2 \mathrm{ft}$. tall. Leaves in whorls of 3's and 8's, rarely alternate, lanceolate, $\mathrm{I}-4$ in. long, roughened on the margin. Flowers $\mathrm{I}-5$, erect, $2-3 \mathrm{~T} / 2$ in. long, the orange-red spotted petals narrowed into a claw towards the base. Pod $\mathrm{I}-2$ in. long. July. Maine and Ontario to No. Car. and West Virginia, usually in thickets or meadows and more rarely in woods. Fig. 94.

95. Western Red Lily. Lilium umbellatum. (L. philadelphicum andinum.) Somewhat similar to the preceding but with narrower, mostly alternate leaves and pods half as long. July. Ontario to Ohio, Mississippi, and southward, mostly in dry places.

96. Canada Lily. Lilium canadense. Stem $2^{1 / 2}-5 \mathrm{ft}$., the oblong or lanceolate leaves nearly all whorled. Leaves $2-6$ in. long, roughened on the margins and on the veins beneath. Flowers drooping, the spotted, recurved, yellow petals not narrowed into a claw towards the base. Pod $1 \mathrm{x} / 2-2$ in. long. June. In woods. Nova Scotia to Georgia and westward. Fig. 96. There is a red-flowered form of this in western N. Y. and Penn.

97. TURK'S-CAP Lily. Lilium superbum. Somewhat like the preceding but mostly taller and larger in all its parts, and differing constantly in the leaves being perfectly smooth, and in the orange-yellow flowers. July-August. Marshes. New Brunswick to No. Car. and westward.

98. Tiger Lily. Lilium tigrinum. Stem dark colored, 2-5 ft. tall. Leaves all alternate, 4-6 in. long, mostly lanceolate or oblong, often the upper ones bearing small bulbs near the base. Flowers drooping, numerous, $3-4 \frac{1}{2}$ in. long. orangered, the petals much recurved. July. Cultivated, and escaping from gardens. New England, New York, and Penn. Native of China. 

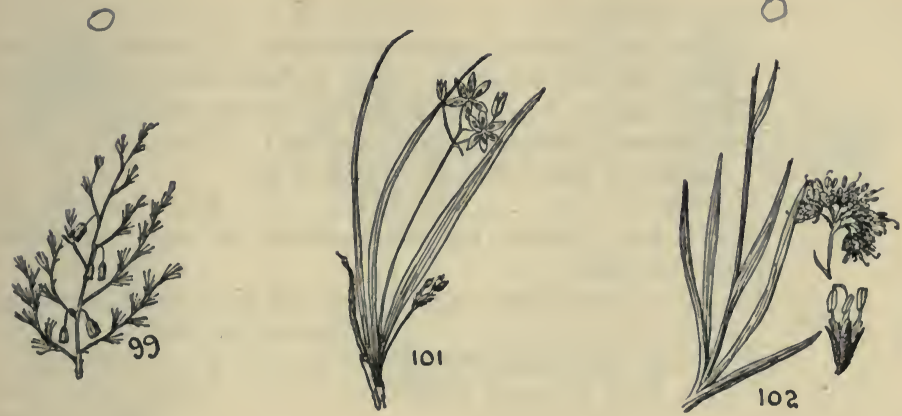

99. ASPARAGUS. ASPARAGUS.

Stems fleshy and unbranched at first, at length feathery and much branched. Leaves reduced to tiny scales, the plant appearing leafless. Flowers small, solitary, or in various sorts of clusters. Petals separate or slightly connected at the base. Fruit a berry. (Convallariaceae.)

Asparagus. Asparagus officinalis. Mature stem much branched, 3-8 ft. high, the tiny clustered branchlets appearing leaf-like. Flower greenish, drooping. Berry red, about $1 / 3$ in. in diameter. May. New Brunswick to Virginia. Cultivated and escaped, but often apparently wild near sand dunes and salt marshes. Native of Europe. Fig. 99.

I00. Leaves long, often grass-like, with the margins parallel, or nearly so. (Exceptions are a Wild Leek, No. 107, the Blazing-star, No. I I9, and the Colic root, No. I 18.) (Nos. IOI-I 29.)

Flower cluster a spike or a simple or branched raceme (see Figs. I17-123) $\ldots \ldots \ldots \ldots \ldots \ldots \ldots \ldots \ldots \ldots \ldots$ no. I16 Flower clusters not spikes or racemes.

Flower more than $1 \frac{1}{2}$ in. long or wide, never white .. no. 112 Flower (not the cluster) less than I in. long or wide, usually much less, if approaching $\mathbf{I}$ in. then white 
Flowers yellow.

Cluster few-flowered, never more than 3-6 flowered, plant hairy but not woolly ........ Yellow Star-grass no. IOI

Clusters more profusely flowered; plants woolly.

Roots red; stamens 3 (see Fig. 102) .. Red Koot no. 102 Roots not red; stamens 6 (see Fig.

I03) ..................... Lophiola no. I03

Flowers not yellow (greenish-yellow in one onion-like herb, No. I06).

Stalks of individual flowers not all arising at the same point ................ Star-of-Bethlehem no. I04 Stalks of individual flowers all arising at the same point (see Figs. I07 and 108) .......... Onions and False

Onion no. 105

Flower solitary, never in clusters ....... Stagger-grass no. II I

\section{ror. YELLOW STAR-GRASS. HYPOXIS.}

Slender grass-like always hairy herbs with star-like yellow flowers in scanty clusters, and basal narrow leaves. Petals united only at the base. Fruit a small pod containing black, angled seeds. (Amaryllidaccae.) The only species is

Yellow Star-grass. Hypoxis hirsuta. Leaves about 1/8 in. wide, usually longer than the stalk of the flower cluster. Flowers I-6, usually 3, the small yellow petals spreading, the flower thus star-like, the outside greenish. Pod about 1/10 in. in diameter. Summer. In various situations. Maine to Florida, and westward. Fig. IOI.

\section{I02. RED ROOT. GYROTHECA.}

A stout herb with fibrous red roots. Leaves basal and also a few on the stem. Flowers numerous, crowded in a terminal woolly cluster, yellow. Stamens 3 (see Fig. 102). Fruit a pod. (Hacmodoraccae.) The only species is RED RoOT. Gyrotheca tinctoria. (Lachnanthes tinctoria.) Not over $2 \mathrm{I} / 2 \mathrm{ft}$, the stem smooth below, woolly towards the top. Leaves scarcely $1 / 2$ in. wide, the basal ones not longer than the stem. Flower cluster $2 \frac{1}{2}-4 \frac{1}{2}$ in. wide. Flowers nearly $1 / 2$ in. long. Pod about $1 / 4$ in. in diameter. August. 
A GUIDE TO THE WILD FLOWERS
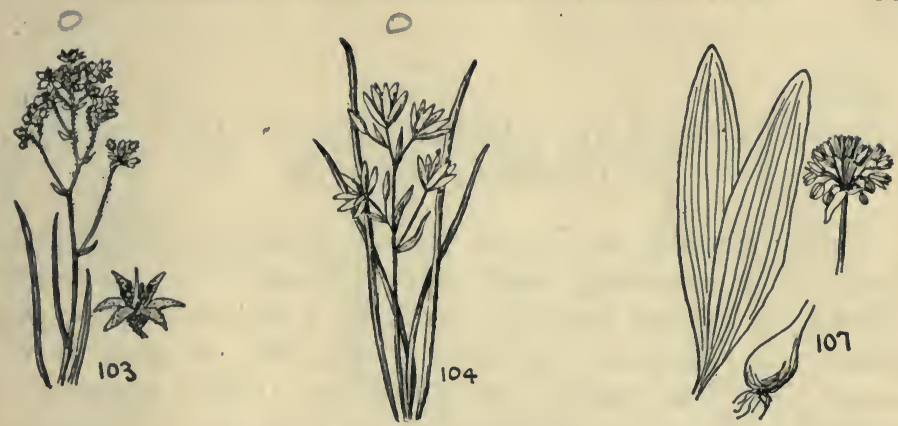

In bogs. Mass. to Florida, mostly near the coast, and always rather rare. Fig. 102.

\section{I03. LOPHIOLA.}

Somewhat similar to the preceding, but with narrower leaves and less crowded flower clusters. Roots not red. Stamens 6 (see Fig. 103). (Amaryllidaceae.)

Lophiola americana. (L. aurea.) No common name. Stems I-2 ft. high, woolly above. Basal leaves considerably shorter than the stem, the stem-leaves much reduced in size upward. Flower cluster not very crowded, white woolly. Flower yellow, the stamens 6 . July. New Jersey to Florida, in pine barren bogs. Fig. I03.

\section{STAR-OF-BETHLEHEM. ORNITHOGALUM.}

Bulbous herbs with nearly fleshy basal leaves. Flowers white in a scanty terminal cluster. Petals separate, white, but usually greenish outside. Fruit a pod. (Liliaceae.)

Star-of-Bethlehem. Ornithogalum umbellatum. Scarcely more than Io in. high. Leaves linear, scarcely $1 / 8$ in. wide, fleshy, the mid-rib lighter colored than the rest of the leaf. Clusters few-flowered. Flowers white, scarcely I in. long. June. Along roadsides, or in cultivated ground. New England to Penn. and Virginia. Native of Europe. Flowers open in the sunlight. Fig. I04. 


\section{ONIONS AND FALSE ONION. ALLIUM AND NOTHOSCORDUM.}

Onion-scented, or, in the False Onion, odorless bulbous herbs with sheathing basal leaves. Flowers sometimes replaced by bulblets (see Fig. I08), in a terminal cluster, the flowers of which are on short stalks that all arise at the same point (an umbel, see Fig. 107). Petals separate or slightly connected at the base. Fruit a small pod. (Liliaceae.)

Plant odorless; flowers yellowish-green ..... False Onion no. 106 Plants onion-scented; flowers not yellowish green.

Leaves oblong, not present at flowering time .. Wild Leek no. 107 Leaves narrowly linear, present at flowering time.

Flowers green or purple, often replaced by

bulblets ..................... Wild Garlic no. 108

Flowers white, rose or pink.

Flowers mostly replaced by bulblets,

the cluster erect .............. Meadow Garlic no. 109

Flowers not usually replaced by bulblets, the clusters nodding $\ldots \ldots \ldots \ldots \ldots \ldots \ldots \ldots \ldots$ Wild Onion no. I Io I06. False Onion. Nothoscordum bivalve. Leaves flat, very narrow, not over $1 / 8$ in. wide, as long as, or slightly shorter than the stalk of the flower cluster. Cluster $3-9$ flowered, yellowish-green. Flowers about $1 / 2$ in. long, their stalks of unequal length. June. Virginia to Ohio and Nebraska, thence southward to Mexico, usually in sandy places.

107. Wild Leek or Onion. Allium tricoccum. Leaves flat, nearly oblong, 6-1O in. long, $\mathrm{I}-2 \mathrm{I} / 2 \mathrm{in}$. wide, appearing and withering before flowering time. Stalk of the flower cluster $6-15$ in. long. Flowers white, about $1 / 2$ in. long, in a many flowered cluster. June. Rich woods. New Brunswick to North Carolina, and westward. Fig. I07.

i08. Wild Garlic. Allium vineale. Stems frequently $2 \mathrm{ft}$. or more. Leaves $2-4$ at flowering time, round and hollow. Flowers numerous, in an erect umbel, green or purple, not over $1 / 5$ in. long, often replaced by long-tailed bulblets. June. Fields and waste places. Rhode Island to Tenn., and Missouri. Native of Europe. Fig. Io8. 

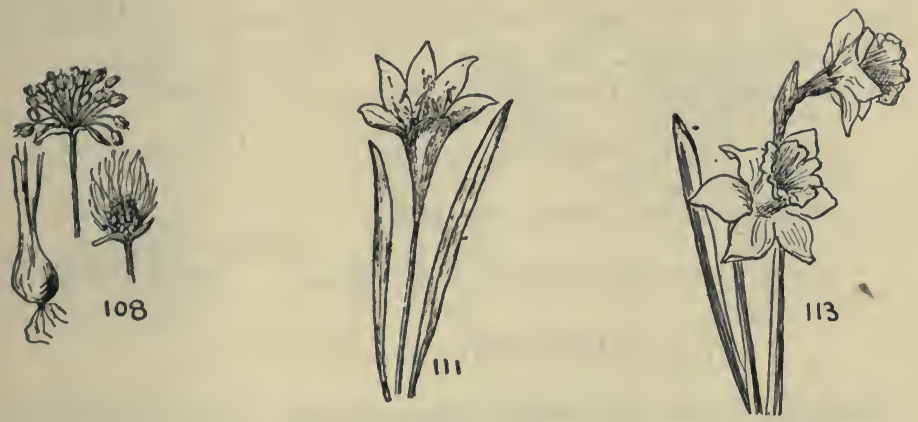

rog. Meadow Garlic. Allium canadense. Bulb prominently fibrous-coated. Stem 10-20 in. high. Leaves nearly flat, scarcely $1 / 12$ in. wide. Flowers in an erect umbel, pink or white, often replaced by long-tailed bulblets. June. New Brunswick to Florida, and westward, mostly in thickets or meadows.

i io. Wild Onion. Allium cermuum. Leaves grooved or flattish, not over $1 / 6$ in. wide. Flowers pink or white, the umbel nodding at flowering time. Summer. New York to West Virginia, and westward. Mostly in woods. A related species, Allium stellatum, the Prairie Wild Onion, differs in having an erect flower cluster and is found on rocky banks from Illinois to Missouri, and westward. It has rose-colored flowers.

IIr. STAGGER-GRASS. ATAMOSCO.

Bulbous fleshy herb with narrow basal leaves and erect solitary flower. Petals separate above, united below into a funnelshaped tube. Fruit a 3-lobed pod, the seeds blackish. (Amaryllidaceac.)

Stagger-grass or Atamosco Lily. Atamosco Atamasco. (Zephyranthes Atamasco.) Leaves fleshy 7-14 in. long, not over $1 / 4$ in. wide. Flower stalk erect, thick, over-topping the leaves. Flower $2-3$ in. long, white, often purplish-tinged. 
Pod about $1 / 2$ in. long. March-April. In meadows, Penn. to Va., and southward. Fig. II I.

II2. Flowers more than $I \frac{1}{2}$ in. long, never white.

Flowers bright yellow .................. Daffodil no. II3 Flowers not yellow

Petals separate, orange and purple spotted ..................... Blackberry lily no. II Petals united into a tube below, orange .... Day lily no. 115

\section{II3. DAFFODIL. NARCISSUS.}

Bulbous herbs with thick basal leaves. Flowers solitary, or in a scanty cluster, the center a funnel-shaped erect crown (see fig. II3); fruit a pod. (Amaryllidaceae.)

Daffodil. Narcissus Pseudo-Narcissus. Flower stalk about I ft. tall, 2-edged. Leaves about as long, narrowly linear. Flower bright yellow, 2-3 in. long. Early spring. Much cultivated, and sometimes escaping. Penn. and N. J. Native of Europe. Fig. II3.

\section{I14. BLACKBERRY LILY. GEMMINGIA.}

Perennial herb, without bulbs. Leaves nearly erect, many veined, folded, and sheathing at the base. Petals distinct and separate. Fruit a pod, broad above, and narrowed at the base, easily splitting and exposing the seeds which are fleshy and black. (Iridaceae.)

Blackberry Lily. Gemmingia chinensis. (Belamcanda chinensis.) From $\mathrm{I} / 2$ to $3 \mathrm{ft}$. tall. Leaves $8-\mathrm{I} 2$ in. long and $\mathrm{I}$ in. wide. Flowers few or many, $\mathrm{I} / 2-2$ in. wide, the petals orange, mottled with crimson or purple, very showy. Pod about I in. long. June. Conn. to Ga., west to Ind. and Kan., as an escape from gardens. Native of Asia, and often cultivated. Fig. II4.

\section{5. DAY-LILY. HEMEROCALLIS.}

Fibrous-rooted tall herb with basal, linear leaves. Flowers large, clustered at the end of a leafless flower-stalk, opening 

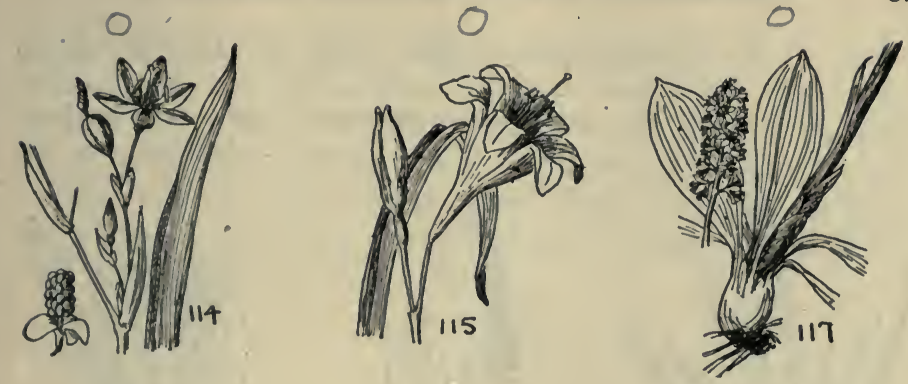

only for a day. Petals separate above and recurved, united below into a funnel-shaped tube. Fruit a 3 -angled pod. (Liliaceae.)

Day-Lily. Hemerocallis fulva. From 3-5 ft. tall. Leaves not quite so long, about $1 / 2$ in. wide, grooved. Flowers $4-5$ in. long, rusty-orange. July. New Brunswick to Va. and Tenn., cultivated and escaping. Native of Europe and Asia. Fig. II5.

I16. Flower-cluster a spike or a simple or branched raceme, see figs. II7-123 (nos. II7-I29).

Flower-cluster decidedly and conspicuously branched .... no. 125 Flower-cluster unbranched (or if branched, only slightly to in no. 124)

Flowers rose-purple ............... Swamp Pink no. I17 Flowers not rose-purple

Leaves with the margins not quite parallel

Leaves all basal ................. Colic Root no. II 8

Leaves basal and also on the stem .. Blazing Star no. II9

Leaves with the margins quite parallel

Leaves very numerous $(30-60)$; plant $3-5 \mathrm{ft} . \ldots \ldots \ldots \ldots \ldots$. Turkey Beard no. 120

Leaves fewer; plants mostly lower

Stalk of the flower-cluster decidedly hairy ........... ..................... False Asphodel no. I2I Stalk of the flower-cluster not hairy

Flower-cluster I-2 in. long; leaves scarcely $1 / 12$ in. wide ................. Bog Asphodel no. I22

Flower-cluster longer; leaves wider 
Flowers white; plant $1 / 2-4 \mathrm{ft}$. high. Fly-poison

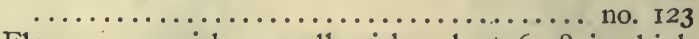
Flowers greenish or yellowish; plant 6-28 in. high

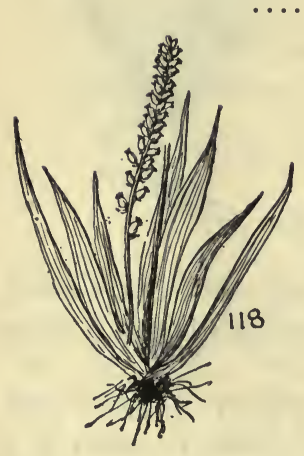
Anticlea no. 124

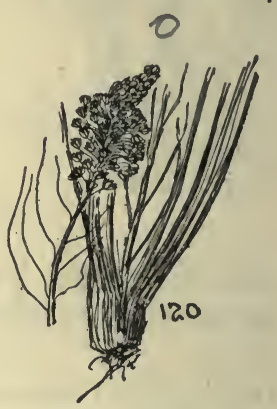

\section{II7. SWAMP PINK. HELONIAS.}

A bog herb with fibrous roots and mostly basal leaves whose margins are not quite parallel. Flowers rose-purple, in a terminal stalked raceme. Petals separate. Fruit a deeply 3-lobed pod. (Melanthaceae.)

Swamp Pink. Helonias bullata. Leaves 6-12 in. long, broadest toward the tip, many-veined, often lasting through the winter. Flower cluster I-3 in. long, elongating in fruit, many flowered. Pod about $1 / 4$ in. long, its valves papery. April. Bogs, N. J. and N. Y. to No. Car. Fig. II7.

\section{Ir8. COLIC ROOT. ALETRIS.}

A fibrous-rooted herb of dry or sandy soils. Leaves all basal, their margins not quite parallel, and apering towards both ends. Flowers in a long-stalked spike-like raceme, white. Fruit a 3 -lobed pod, sheathed by the remains of the flower. (Liliaceae.) 
Colic Root or Star Grass. Aletris farinosa. Sometimes $3 \mathrm{ft}$. tall, but usually lower. Leaves $2-5$ in. long, pointed at the tip, pale greenish yellow, not quite $\mathbf{I}$ in. wide. Flower cluster $4-10$ in. long, elongating in fruit. Flowers almost stalkless, about $1 / 4$ in. long. Pods ovoid, about $1 / 6$ in. long, their lobes all short-tipped. July. In open places, Me. to Fla., and westward. Fig. I 18.

\section{I19. BLAZING STAR. CHAMAELIRIUM.}

Somewhat fleshy herbs of moist places, with thickened roots. Leaves basal, and on the stem, broadest toward the tip. Flowers in a long-stalked spike-like raceme, white. Fruit a scarcely lobed pod, not surrounded by the remains of the flower. (Mclanthaceae.)

Blazing Star. Chamaelirium luteum. From $1 \mathrm{~T} / 2-2 \mathrm{~T} / 2 \mathrm{ft}$. tall. Basal leaves $2 \frac{1}{2}-7$ in. long, broadest towards the tip, long-stalked, the stem leaves smaller and stalkless. Flower cluster $3-9$ in. long, elongating in those producing fruit. Flowers about $1 / 4$ in. wide. Pod nearly oblong, about $1 / 2$ in. long. Many plants produce no fruit. June. Mass. to Fla., west to Mich. and Ark., mostly in meadows and moist thickets. Fig. I I9.

\section{I20. TURKEY-BEARD. XEROPHYLLUM.}

Tall herb of dry pine-barrens with very numerous, almost thread-like roughish leaves. Flowers white, many, in a large terminal cluster, the lower opening first, soon withering, but persistent. Fruit a 3-grooved pod. (Melanthaceae.)

Turkey-BEard. Xerophyllum asphodeloides. Frequently 3-4 ft. high, and stout. Leaves basal and on the stem, the lower longer, very numerous, $6-20$ in. long. Flower cluster 3-7 in. long, the individual flower stalks about I in. long. Pod about $1 / 6$ in. long. June. Dry pine-barrens, southern N. J. to Fla. and eastern Tenn. Fig. I20. 

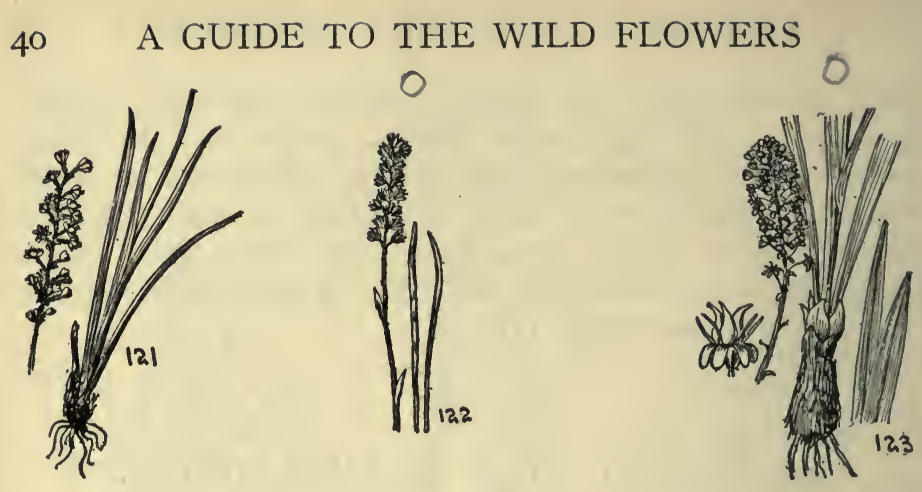

I2I. FALSE ASPHODEL. TRIANTHA.

Swamp herbs with hairy leaves and flower stalks. Flowers in a terminal cluster those above opening first, greenish-white, often persistent. Fruit an unlobed pod. (Melanthaceae.) False Asphodel or Tofieldia. Triantha racemosa. (Tofieldia racemosa.) Stems $\mathrm{I}-3 \mathrm{ft}$. high. Leaves linear, 6-I 5 in. long, and about $\mathrm{I} / 8$ in. wide. Flower cluster $\mathrm{I}-4$ in. long, the flowers in groups of 3 . Petals separate and distinct. Pod about $1 / 8$ in. long. Summer. Bogs, southern N. J. to the Gulf. Fig. I2I. A related species with larger pods, Triantha glutinosa, is found from Newfoundland and Maine to Minn.

\section{BOG ASPHODEL. $A B A M A$.}

Smooth bog or swamp herbs with thickened roots, and basal and stem leaves. Flowers in a terminal cluster, greenishyellow. Fruit a tapering pod, the seeds tailed. (Melanthat eae.) Bog Asphodel. Abama americana. (Narthecium americanum.) Stems wiry, 8-18 in. tall. Leaves $3-7$ in. long scarcely $1 / 12$ in. wide, $7-9$ veined, much reduced on the upper part of the stem. Flower-cluster I-2 in. long, the flowers scarcely $1 / 4$ in. long. Summer. Southern N. J. and Delaware, in pine-barren bogs. Fig. I22. 


\section{FLY-POISON. CHROSPERMA.}

A bulbous herb of sandy woods. Leaves nearly all basal, blunt, and long. Flowers white, in a terminal raceme, the lower expanding first. Petals blunt. Fruit a deeply 3-lobed, and slender-tipped pod. (Melanthaccae.)

FLy-POISON OR CROW-POISON. Chrosperma muscaetoxicum. (Amianthium muscactoxicum.) From I $1 / 2-4 \mathrm{ft}$. high. Leaves $1 / 2-I$ in. wide, a little shorter than the stem, those on the upper part of the stem decidedly smaller. Flower cluster $2 \frac{1}{2}-5$ in. long, the stalks of the individual flowers ascending. Pod about $1 / 4$ in. in diameter. June. Moist sandy places. Long Island and Penn. to Fla. west to Mo. and Ark. Fig. I23.

124. $A N T I C L E A$.

Bulbous, leafy-stemmed herbs with terminal flowerclusters. Flower greenish-yellow. Fruit a 3-celled pod, its lobes tipped. (Melanthaceae.)

Anticlea elegans. (Zygadenus chloranthus.) No common name. From $1 / 2-3$ ft. tall. Leaves $1 / 6-1 / 2$ in. wide, keeled, the basal nearly I $\mathrm{ft}$. long, the upper shorter. Flower cluster mostly a simple raceme, very rarely branched, often I $\mathrm{ft}$. long. Flowers nearly $I$ in. across. Pod about $I$ in. long. July. New Brunswick to N. Y., and westward, mostly in mountains. Fig. I24.

125. Flower cluster decidedly and conspicuously branched. (Note: The first preceding sometimes has a branched flower cluster.)

Individual flower $\mathrm{I}^{1} / 2$ in. long or more .. Adam's Needle. no. 126 Individual flower less than $I$ in. long or wide.

Leaves scarcely $1 / 4$ in. wide ........... Oceanorus no. 127 Leaves at least $1 / 2$ in. wide

Flowers greenish-yellow; petals blunt Bunch-flower no. 128 Flowers white or greenish; petals acute-tipped 


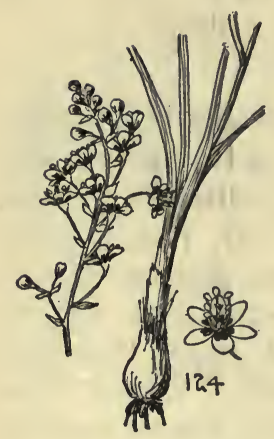

0

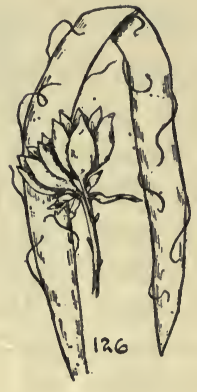

O

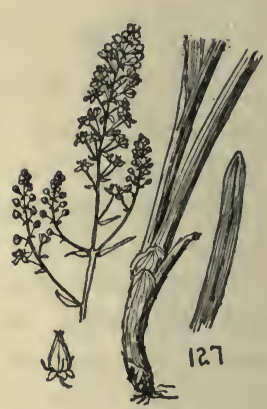

I26. ADAM'S NEEDLE. $Y U C C A$.

Sometimes with a short woody stem, but the crown of leaves mostly basal. Leaves thick and leathery, the margins fibrous. Flower-cluster large, often 2-Io ft. tall, the flowers white. Fruit an oblong pod. (Liliaceae.)

Adam's NeEdle. Yucca filamentosa. Woody stem very short or wanting. Leaves sharp-pointed, roughish, I-2 ft. long, I-2 in. wide. Flower cluster much branched, the lower branches often I ft. long, the individual flowers bell-shaped and nearly $I$ in. high. Pod $I \frac{1}{2}-2$ in. long. June. Maryland to the Gulf. Cultivated and sometimes escaping farther north. Fig. 126.

\section{I27. Oceanorus.}

A smooth, nearly bulbous swamp herb, with narrow leaves, the outer sheathing and fibrous towards the base. Flowers very numerous, green or white, in a branched cluster that is often I ft. long. Fruit a 3-tipped erect pod. (Melanthaceae.)

Oceanorus leimanthoides. (Zygadenus leimanthoides.) No common name. Stem I-4 ft. tall. Leaves about I ft. long, green both sides, blunt. Flower cluster much branched, the flowers about $1 / 3$ in. wide. Pod about $1 / 4$ in. long. Summer. Long Island, N. Y., to Tennessee and Georgia, in moist sand. Fig. 127. 


\section{BUNCH-FLOWER. MELANTHIUM.}

Leafy herb of moist places, the upper part of stem and flower cluster hairy. Leaves narrow, often sheathing. Flowers greenish-yellow, or white, numerous, in a large terminal branched cluster. Fruit a 3-lobed pod. (Melanthaceae.)

BUNCH-FLOWER. Melanthium virginicum. From $2 \frac{1}{2}-5 \mathrm{ft}$. tall, leaves linear, nearly I ft. long, $\mathrm{I} / 2-\mathrm{I}$ in. wide, diminishing upward. Flower cluster 6-18 in. long. Flowers scarcely $3 / 4$ in. wide, turning brown. Pod about $1 / 2$ in. long. July. In various situations, mostly rather moist, Rhode Island and New York to Florida, and westward. A related species, Melanthium latifolium, with leaves broadest above the middle and with fragrant flowers is found from Conn. to Penn. and So. Carolina.

\section{STENANTHIUM.}

Bulbous herbs of moist places. Leaves basal and on the stem, linear and keeled. Flowers greenish-white, in terminal branched clusters. Fruit a 3-lobed pod. (Melanthaceae.)

Stcnanthium robustum. No common name. Stem 3-5 ft. high, leafy. Leaves I $\mathrm{ft}$. or more long, $\mathrm{I} / 2-\mathrm{I}$ in. wide. Flower cluster I-2 ft. long, much-branched. Flowers greenish, or white, the petals acute-tipped. Pod about $1 / 2$ in. long. August. Penn. and Ohio to Tenn., So. Carolina, and Missouri. Fig. I29.

I30. Twining vines.

Flowers in a long stalked ball-like cluster; fruit a bluish-black berry $\ldots \ldots \ldots \ldots \ldots \ldots \ldots \ldots$. Carrion-flower no. 131 Flowers in a simple or branched cluster, not ball-like; fruits 3-angled and dry $\ldots \ldots \ldots \ldots \ldots \ldots$ Wild Yam-root no. 132 

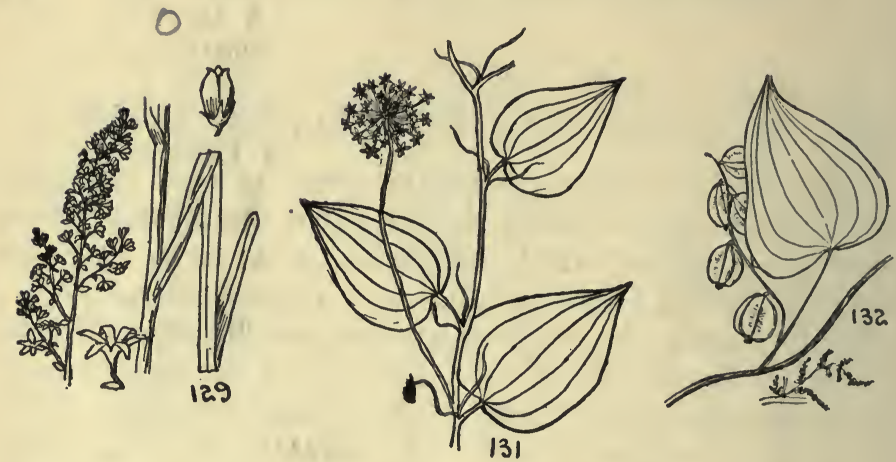

I3I. CARRION-FLOWER. SMILAX.

Several species of Smilax are woody, prickly vines, which, as Catbriers, make the least attractive of our climbing plants, and are omitted from this book. One common species is, however, unarmed, but has a perfectly smooth stem and I8-50 ill-scented flowers borne at the end of a long stalk in a close ball-like cluster, followed by a bluish-black berry. (Smilaceae.)

CARrion-Flower. Smilax herbacea. A much branched scrambling vine, with 7-9 veined oval leaves, that are heartshaped at the base, and pointed at the tip. Leaf-blade, $\mathrm{I} / 2-5$ in. long, and $I-3 \frac{1}{2}$ in. broad. Flowers greenish-yellow, the stalk of the ball-like clusters arising from among the leafstalks, not at the ends of the branches. Berries 2-4 seeded, less than $1 / 2$ in. in diameter. June. Common in thickets, less so in woods. New Brunswick and Ontario, south to Florida, and westward. Fig. I3I. There are two or three related unarmed species of Smilax and at least 7 very prickly Catbriers with more or less woody stems.

\section{WILD YAM-ROOT. DIOSCOREA.}

Twining vines, common in the tropics, where the underground parts of some species are widely eaten as yams. 


\section{A GUIDE TO THE WILD FLOWERS}

There is only one species in northeastern America, 'wholly without prickles. The stems are often a little woody, and usually from $5^{-12} \mathrm{ft}$. long. Flowers, very small, greenishyellow, in drooping slender clusters, 6-parted. Fruit dry greenish, strongly 3 -winged. (Dioscorcaccac.)

WiLd YAM-ROOT. Dioscorca villosa. A scrambling vine with long stalked leaves that are heart shaped at the base, and prolonged into a pointed narrow tip, 9-1 3 veined, usually a little hairy on the under surface. Fruits in hanging, loose, rather sparse clusters, almost $\mathrm{I}$ in. long, and nearly as wide. June. Moist thickets. Ontario and southern New England to Florida, and westward. Fig. I32.

I33. Flowers very irregular and unsymmetrical.

Leaves not long stalked and heart shaped at the base; flowers never blue $\ldots \ldots \ldots \ldots \ldots \ldots \ldots \ldots \ldots$ Orchids no. 135 Leaves long stalked and heart shaped at the base; flowers blue, a plant of swamps or water-sides ...... Pickerel-weed no. 134

\section{PICKEREL-WEED. PONTEDERIA.}

Thick stemmed, almost fleshy herbs growing along the edges of, or often in, swamps or ponds. Leaves thick, manyveined, long stalked, nearly always heart shaped at the base (in one form narrowed). Flowers in a dense terminal cluster, blue, split into two parts (lips) of unequal size. Upper lip of 3 lobes, the lower lip of 3 linear, spreading lobes. Fruit bladder-like. (Pontederiaceae.)

Pickerel-ween. Pontederia cordata. Stems I-4 ft. tall. Leaves oval, $3-9$ in. long, about half as wide. Flower cluster, 3-4 in. long, bright blue, sticky-hairy. Summer. Nova Scotia to Florida, and westward. Fig. I34. 


\section{I35. ORCHIDS OR ORCHID FAMILY. ORCHID- $A C E A E$.}

\section{(Nos. I36-185.)}

A large family of plants best developed in the tropics but found here in considerable numbers. Leaves various as to shape, always without teeth and sheathing at the base (reduced to tiny scales in the coral-roots, No. 136 and in one species of Ladies'tresses No. I5I). lowers solitary or in clusters, always irregular and unsymmetrical, composed of 6 segments, the 3 outer similar or nearly so, the inner ones with usually 2 alike, the third inner one (lip) dissimilar and spurred or otherwise unlike the other inner segments. Fruit a 3 -valved pod. About 60 species are known here of which the following are the commonest.

Leaves present at flowering time, reduced to tiny scales, the plant thus appearing leafless; parasitic orchids with the stems not green $\ldots \ldots \ldots \ldots \ldots \ldots \ldots \ldots$ Coral-roots no. 136

Leaves well developed, present or absent at flowering time; stems, if any, usually green

Leaves apparently or actually absent at flowering time Flowers in terminal clusters

Flowers green, tinged with purple Cane-fly orchids no. 137

Flowers yellowish-brown .......... Putty-root no. I38 Flowers mostly solitary, rose-purple ...... Arethusa no. I39

- Leaves present at flowering time (reduced and almost scalelike in I species of ladies' tresses no. I5I)

Flower like an inflated sac ...... Ladies' slippers no. I40 Flowers not inflated

Leaves mostly borne on the stem, few or none of them basal, (but basal in I species of Adder's-mouth, (See

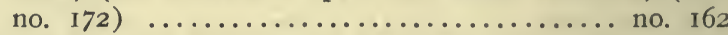

Leaves mostly all basal, a few sometimes borne on the lower part of the stem (There is I basal-leaved Adder's-mouth, no. I72)

Leaves with the margins parallel, or nearly so, several times longer than broad

Flowers rose-purple ........... Grass-pink no. I46 Flowers not rose-purple

Leaf solitary; flowers greenish-yellow

Bog orchis, no. 147 

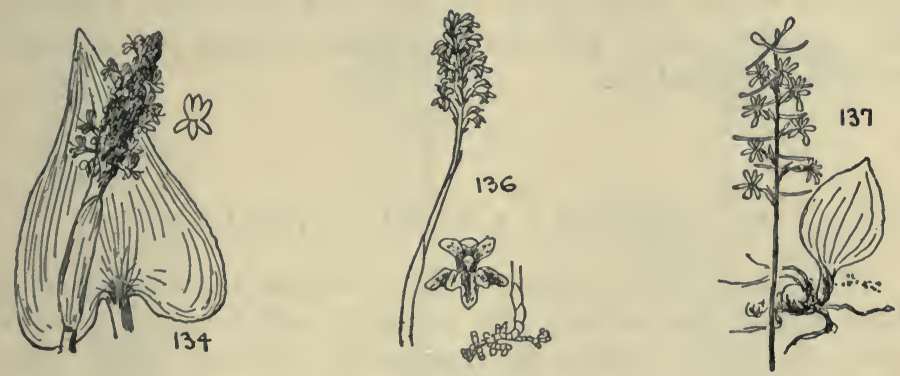

Leaves more numerous; flowers cream or white ....... Leaves of a. .................... Ladies' tresses, no. I 48 sometimes as broad as long Leaves mottled with white, thus appearing variegated .. Rattlesnake plantain no. 152 Leaves plain green

Leaf solitary; flowers rose-white and purple spotted ... Small Orchis no. 156

Leaves 2.

Flowers violet-purple ....... Showy Orchis no. 157 Flowers white or greenish.

Leaves nearly round, flat on the ground; plant I $\mathrm{ft}$. high or more ......... Large orchis no. ${ }^{158}$ Leaves of an oval type, erect; plant less than 10 in. high $. . . \ldots \ldots \ldots \ldots . .$. Twayblades no. I59

\section{CORAL-ROOT. CORALLORRHIZA.}

Parasitic or partially parasitic herbs with numerous scalelike leaves and flowers in terminal clusters. Plants never green. Flowers tubular and swollen on one side, usually yellowish-brown, or purplish. Pods often drooping. Six species are known, separated wholly by technical characters. The commonest is

Coral-root. Corallorrhiza maculata. Stalk of the flowercluster 8-I5 in. high, quite leafless, and purplish. Flowercluster $2-6$ in. long, the flowers mostly brownish-purple, about $1 / 4$ in. long. Pod about $1 / 2$ in. long, drooping. August. 
In rich woods, Nova Scotia to Fla. and westward. Fig. I36. For several other and nearly similar species the manuals should be consulted.

\section{I37. CANE-FLY ORCHIS. TIPULARIA.}

Bulbous orchids of deep woods, the flower cluster opening long before the solitary leaf appears, which often happens after the flower stalks have withered. Flowers green, long spurred, in a loose terminal cluster, the stalk often with several sheathing scales towards the base. Our only species is Cane-fly Orchis. Tipularia unifolia. ( $T$. discolor.) Leaf solitary, appearing in autumn, 2-3 in. long, half-evergreen. Flower-cluster 5-8 in. long, loose and lax. Spur often twice as long as the rest of the flower. Pod about $1 / 2$ in. long 6-ribbed. Summer. Rare in deep woods, Mass. to Fla. and westward. Fig. I37.

\section{I38. PUTTY-ROOT. APLECTRUM.}

Bulbous orchids of woods, or more rarely swamps, with the stalk of the flower-cluster having several sheathing scales. Flowers in terminal clusters, not present with the leaves, yellowish-brown or purplish, not spurred. Fruit an angled pod. The only known species is

Putty-root or Adam-And-Eve. Aplectrum hyemale. Stalk of the flower-cluster I-2 ft., with about 3 scales. Leaves developing after flowering time, oval, 2-3 in. long, often partly evergreen. Flower-cluster $2-4$ in. long. Flower about I in. long, the pod about as long. May-June. Ontario to Ga. and westward. Fig. I38.

\section{I39. ARETHUSA.}

Showy bog or swamp orchids with a bulbous root and solitary rose-purple flowers. Leaf solitary, small, and appearing 

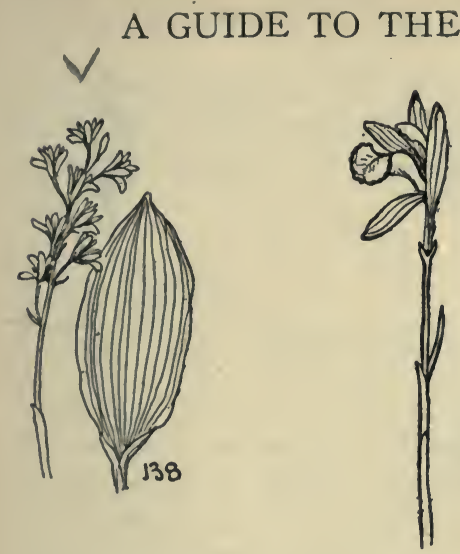

WILD FLOWERS

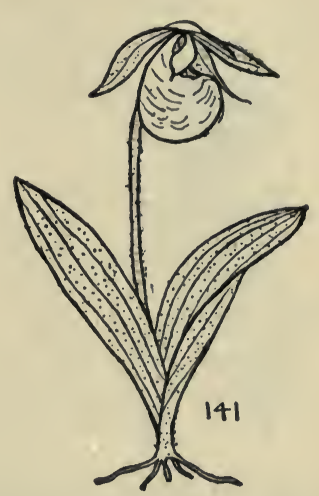

after flowering from the scale-like sheaths of the stem. Flower with the lip often fringed or toothed. Pod erect, angled.

Arethusa or Dragon's-mouth. Arethusa bulbosa. Stem 5-8 in. long, clothed with several sheathing scales, from among one of which the solitary leaf arises. Flower I-2 in. long, the lip drooping and fringed. Pod about $\mathrm{I}$ in. long. May-June. Newfoundland to S. Car. Minn. and Ind. Fig. I39.

\section{r40. LADIES'-SLIPPER. CYPRIPEDIUM.}

Large showy orchids with fibrous roots and hairy, broad, many-veined leaves. Flowers large sac-like and inflated. Fruit an angled pod.

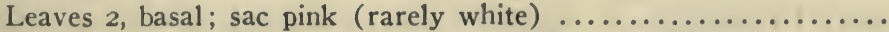

........................... Moccasin Flower no. I4I

Leaves more than 2, mostly on the stem.

Sac yellow ................ Yellow Ladies'-slipper no: 142

Sac not yellow

Sac I-2 in. long, with white and crimson stripes ...........

Sac mostly less than I in. long

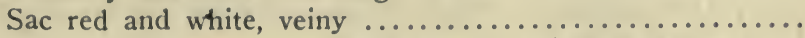

Ram's-head Ladies'-slipper no. 144

Sac white, purplish-striped inside

White Ladies'-slipper no. 145 

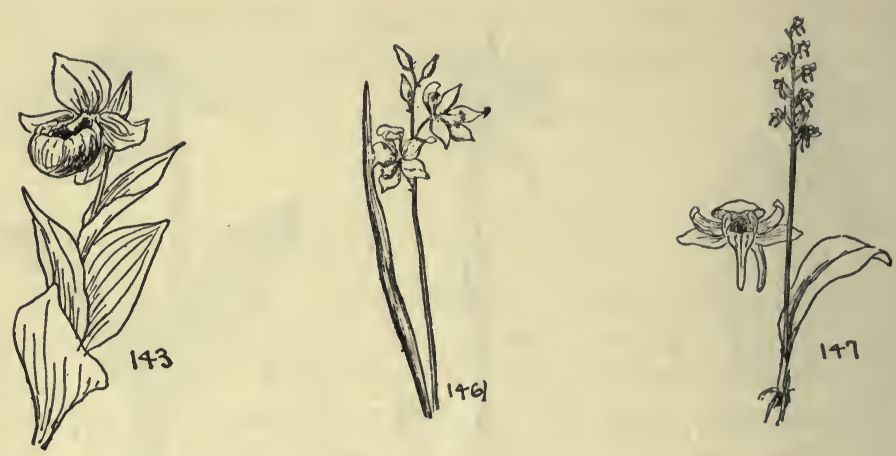

I4I. Moccasin Flower or Pink Ladies'-slipper. Cypripedium acaule. Leaves elliptic, 5-8 in. long, many-veined and plaited. Flower solitary, the pink sac nearly 2 in. long, very showy. Pod angled, about $\mathrm{I} / 2$ in. long. May-June. In dry woods Newfoundland to N. Car. and Tenn. west to Man. and Minn. Fig. I4I.

142. Yellow Ladies'-SLIPPER. Cypripedium parviflorum. Stems I-2 ft. tall, leafy to nearly the top. Leaves oval or oblong, 2-6 in. long, half as wide. Flower mostly solitary, the sac yellow, 3/4-2 in. long. June. New Brunswick to Ala. and westward, mostly in rich woods.

143. Showy Ladies'-Slipper. Cypripedium reginae. ( $C$. hirsutum.) Stem stout and hairy, $\mathrm{I}-2 \mathrm{ft}$. tall, leafy to the top. Leaves oval, acute at the tip, 3-6 in. long, $I-3 \frac{1}{2}$ in. wide. Flowers usually, but not always more than I, the sac much inflated, white, with crimson stripes, I-2 in. long. Summer. In swamps or woods; Newfoundland to Ontario and Minn. south to Ga. Fig. I43.

144. Ram's Head Ladies'-SLIPPER. Cypripedium arictinum. Not over I ft. high, the flower solitary. Leaves 3 or $4,2-4$ in. long, elliptic or lanceolate. Sac not much inflated, red and white, the tip narrowed into a blunt spur, about $3 / 4 \mathrm{in}$. long. June-July. In cold woods, Quebec to New England, N. Y. and west to Minn.

I45. White Ladies'-SLipper. Cypripedium candidum. From 6-I2 in. high and leafy. Leaves $3-5$ in. long, $3 / 4-1 \frac{1}{2}$ in. wide, 
their bases sheathed with blunt scales. Flower solitary, the sac white, purple-striped inside, scarcely an inch long. In moist open places: N. Y. and $\mathrm{Ky}$. westward, rare eastward. June.

\section{GRASS-PINK. LIMODORUM.}

Bog or meadow orchid with a solid bulb. Leaf solitary, followed the second year by the flowers. Flowers several in a loose terminal cluster purplish-pink, not fringed. Fruit an erect oblong pod. Our only species is the

Grass-pink or Calopogon. Limodorum tuberosum. (Calopogon pulchellus.) Not over I $1 / 2 \mathrm{ft}$. Leaf linear or lanceolate $8-12$ in. long, less than $I$ in. wide. Flower cluster 4-12 in. long, with $3^{-15}$ flowers, the latter not quite $I$ in. long. Lip crested, not fringed, with orange or rose-colored hairs. June. Newfoundland to Fla. and westward. Fig. I46.

\section{I47. BOG ORCHIS. LYSIELLA.}

A high-mountain bog orchid with fibrous roots and a single leaf. Flowers few, in a terminal spike, greenish-yellow, the lip not fringed. Fruit an ovoid pod, but broader toward the tip.

Bog ORCHIs. Lysiclla obtusata. (Habenaria obtusata.) Scarcely I ft. high, the stalk of the flower-cluster 4 -sided. Leaf basal, broadest toward the tip, $2-4 \frac{1}{2}$ in. long, $1 / 2-I$ in. wide. Spike about $13 / 4$ in. long, the flowers scarcely $1 / 4$ in. long, and spurred. August. New Brunswick to British Columbia and in the mountains of Me. and N. Y. (Adirondacks.) Fig. I47.

148. LADIES'-TRESSES. IBIDIUM. (SPIRANTHES.)

Erect slender orchids with fibrous or fleshy roots. Leaves basal or on the lower part of the stem, or reduced to small 

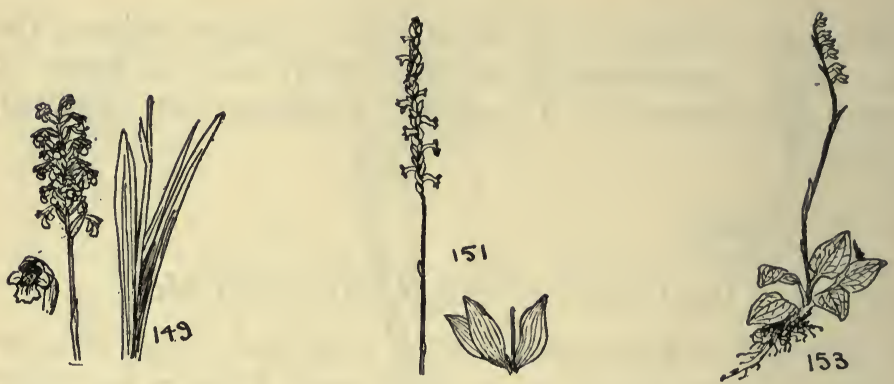

scales in one species. Flowers white or cream, in a slender, partially twisted, terminal spike, not spurred. Lip not fringed. Fruit an erect pod. There are several species, mostly distinguished by technical differences, of which the following are best known.

Leaves linear, conspicuous, at least 4 in. long.

Spike about $1 / 2$ in. thick, not much twisted

..................... Drooping ladies'-tresses no. I49 Spike scarcely $1 / 2$ in. thick, conspicuously twisted ............

.................. Grass-leaved ladies'-tresses no. I50

Leaves broadest toward the tip, wholly basal and often early withering, the plant thus appearing leafless, not over 2 in. long. ........................ Slender ladies'-tresses no. I5 I 149. Drooping Ladies'-tresses. Ibidium cernuum. Stem I/2$2 \mathrm{ft}$. high, often hairy towards the top, usually clothed with sheathing scales. Leaves 4-12 in. long, nearly linear. Flowercluster not much twisted, 4-5 in. long, the flowers numerous, fragrant, scarcely $1 / 2$ in. long. September. Meadows from Newfoundland to Fla. and westward. Fig. I49. A related species, Ibidium plantagineum, which is lower and with smaller flowers and broader leaves is found from Nova Scotia to Va. and westward.

150. Grass-leaved Ladies'-tresses. Ibidium praecox. Stem $\mathrm{I}-2 \mathrm{I} / 2 \mathrm{ft}$. tall, slightly sticky-hairy near the top. Leaves linear, 5-12 in. long, grass-like. Flower-cluster much twisted, 3-7 in. long, scarcely $1 / 2$ in. thick, the flowers about $1 / 4$ in. long. Summer. Coastal meadows from N. J. to the Gulf. A related species, Ibidium vernale, with a very sticky-hairy stem, smaller, yellowish flower, and shorter leaves is found from 
Mass. to the Gulf and northward in the Mississippi valley to Ill. and Kan.

151. Slender Ladies'-tresses. Ibidium gracile. Stem nearly or quite hairless, $3 / 4-2 \mathrm{ft}$. tall. Leaves basal, broadest towards the tip, $1 / 2-2$ in. long, withering early. Stalk of the flowercluster with several sheathing scales. Flower-cluster I-3 in. long, scarcely $1 / 2$ in. thick, conspicuously twisted. Flowers scarcely $1 / 8$ in. long. September. Meadows, Nova Scotia to Fla. and westward. Fig. I5I.

\section{RATTLESNAKE PLANTAIN. PERAMIUM. (EPIPACTIS.)}

Woodland, hairy orchids with several basal leaves and fleshy fibrous roots. Leaves usually blotched with white. Flowers in a terminal spike, white or greenish, not fringed, the lip roundish or oval. Fruit a pod that often droops when ripe.

Flower-cluster loose, usually I-sided.

Leaves tapering gradually towards the base $\ldots \ldots \ldots \ldots \ldots \ldots$.

........................... Squirrel-ear no. I53

Leaves broad at the base and abruptly narrowed into the leafstalk ................... Rattlesnake Plantain no. 154

Flower cluster dense, not I-sided ... Rattlesnake Plantain no. I55 I53. Squirrel-ear or Rattlesnake Plantain. Peramium ophioides. Stalk of the flower-cluster 5-12 in. high, stickyhairy. Leaves oval, blotched with white, gradually tapering toward the base, about $\mathrm{I} 1 / 2$ in. long. Flower-cluster $\mathrm{I}$-sided, not over $2 \mathrm{in}$. long, the flower about $1 / 8$ in. long. July. Newfoundland to S. Car. and westward, in rich woods. Fig. I53. I54. Rattlesnake Plantain. Peramium tesselatum. Similar to the preceding but with larger leaves, broad at the base and abruptly narrowed into the leafstalk. Flowers and spikes larger. August. Usually in evergreen woods: Newfoundland and Ont. to Pa. and Mich.

I55. Rattlesnake Plantain. Peramium pubescens. Stalk of the flower-cluster $5^{-1} 8$ in. high, very sticky-hairy. Leaves oval, broad at the base, and abruptly narrowed into the leaf- 

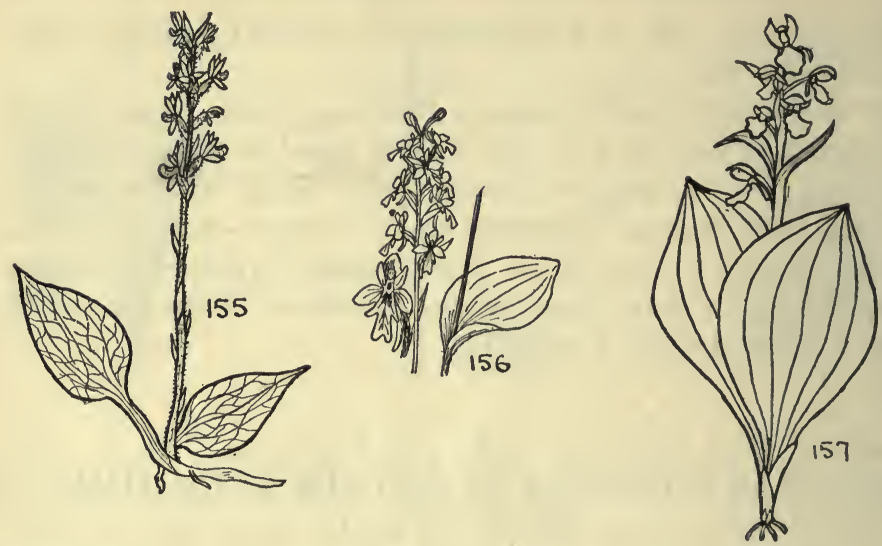

stalk, I-2 in. long. Flower-cluster not I-sided, the flowers about 1/4 in. long, greenish-white. July. Woods. Me. to Fla. and westward, the commonest species eastward. Fig. I55.

\section{SMALL ORCHIS. ORCHIS.}

A damp-woodland orchid with a single basal leaf. Flowers in a short terminal flower-cluster, rose-purple and white. Lip 3-lobed, but not fringed, short-spurred. Fruit an oblong, erect pod.

Small Orchis. Orchis rotundifolia. Not over Io in. high, the single basal leaf oval or nearly round, $1 \frac{1}{2}-3$ in. long, nearly as wide. Spike with 2-6 flowers. Outer segments of the flower rose-color, the lip white and spotted with purple, about $3 / 4$ in. long. June-July. Greenland to the mountains of Me. and N. Y. westward to Wisc. and the Rocky Mts. Fig. I56.

\section{I57. SHOWY ORCHIS. GALEORCHIS.}

An orchid of rich woodlands with 2 basal, rather clammy leaves. Flowers showy, in a loose spike, with scale-like leafy 

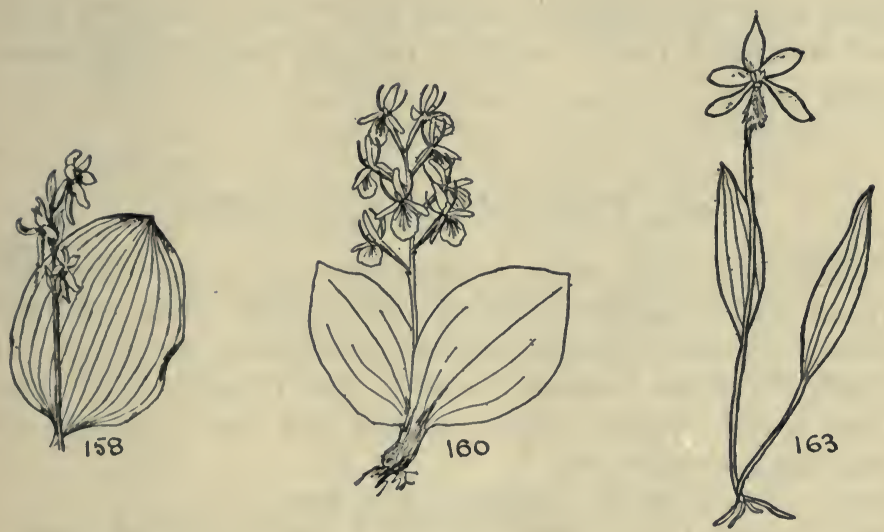

organs just below it. Flowers violet-purple and white, mixed with lighter purple, the lip wavy, not fringed, and produced into a short spur. Fruit a strongly-angled pod.

Sirowy Orchis. Galcorchis spectabilis. (Orchis spectabilis.) Stems 5-angled, not over $\mathrm{I} \mathrm{ft}$. tall. Leaves broadest toward the tip less than 8 in. long, half as broad. Spike 3-6 flowered. Flowers about $\mathrm{I}$ in. long. Pod I in. long. May. New Brunswick to Ga. and westward. Fig. 157 .

\section{LARGE ORCHIS. LYSIAS.}

Stout orchids of mountain woods with 2 large basal leaves and a long loose, terminal raceme of greenish-white flowers. Lip not fringed, narrow, the spur long and narrow. Fruit a cylindric or club-shaped, decidedly stalked pod. LARGE ORCHIS. Lysias orbiculata. (Habcnaria orbiculata.) Stalk of the flower cluster I-2 ft. clothed with small, scalelike leaves. Leaves nearly round, about $5^{1 / 2}$ in. in diameter, silvery below, flat on the ground. Flowers about $1 / 2$ in. long, on short stalks. Lip white, nearly $1 / 2$ in. long. Summer. Newfoundland to N. Car., not near the coast, and westward. Fig. 158. A related species, Lysias Hookcriana which differs in having the stalk of the flower cluster without 
small scale-like leaves, is found from Nova Scotia to N. J. and westward, rare or wanting near the coast, except northward.

\section{TWAYBLADES. LIPARIS.}

Bulbous orchids with 2 basal erect leaves and the stalk of the flower-cluster sheathed with several small scale-like leaves. Flowers greenish-white in terminal racemes. Lip usually broadest toward the apex, not fringed; spur none. Fruit a club-shaped, angled, stalked pod. Nos. I74-176 are also called Twayblades.

Flower cluster profuse, sometimes 6 in. long.

r6o. Twayblade. Liparis liliifolia. From 4-9 in. tall. Leaves oval, $2-5$ in. long, about half as wide, keeled below. Flowercluster sometimes 6 in. long, the flowers about $1 / 2$ in. long. Lip wedge-shaped, as long as the petals. Pod about $1 / 2$ in. long. June. Woods, Me. to Ga. and westward. Fig. I6o.

Flower-cluster scanty, never more than 3 in. long.

r6r. Twayblade. Liparis Loeselii. Similar to the preceding but smaller in all its parts and with the lip mostly shorter than the petals. June. Nova Scotia to Ala. and westward, not common.

162. Leaves mostly borne on the stem, few or none of them basal, but basal in I species of adder's mouth, see under no. I72. (Nos. I63-184.)

Flowers crested or fringed or bearded, see figs. $163-169$

Leaves $\mathrm{I}-3$, usually only $\mathrm{I}$.......... Rose Pogonia, no. I63 Leaves more numerous

Flowers $\mathrm{I}$ or 2 ; leaves $5 \mathrm{in}$. a whorl at the top of the stem ....................... Whorled Pogonia no. I64

Flowers more numerous, in clusters; leaves scattered on the stem $\ldots \ldots \ldots \ldots \ldots \ldots \ldots$. Fringed Orchis no. 165 Flowers not crested or fringed (roughish in the nodding pogonia, no. 177) sometimes spurred, see figs. $178-184$

Leaf solitary $\ldots \ldots \ldots \ldots \ldots \ldots \ldots \ldots$. Adder's-mouth no. I72 Leaves $2 \ldots \ldots \ldots \ldots \ldots \ldots \ldots \ldots \ldots$ Twayblades no. 173 Leaves more than 2 (only $\mathrm{I}-3$ in one orchis, see no. 182) 
Most of the flowers borne along the stem, from among the leaves ................. Nodding Pogonia no. 177 All the flowers terminal

Bracts of the lower flowers in the cluster 2 or 3 times as long as the flower, see fig. 178 . Bracted green orchis no. 178 Bracts of the lower flowers not so long Spur longer than the lip, see figs. I79 and 181

Stem round; flowers greenish yellow .............. ....................... Green orchis no. 179 Stem angled; flowers white or orange yellow .................... Gymnadeniopsis no. 180 Spur about as long as the lip, see fig. 184

.......................... Limnorchis no. 183

163. ROSE POGONIA. POGONIA.

Fibrous-rooted bog or swamp orchids with terminal solitary flowers and I-3 leaves. Lip bearded or crested. Fruit an erect, oblong or ovoid pod.

Rose Pogonia or Snake-mouth. Pogonia ophioglossoides. Stem 8-I 5 in. tall. Leaves I-3, mostly I, borne on the stem, erect, lance-oval, $I-2 \frac{1}{2}$ in. long. Sometimes there is also a long-stalked basal leaf. Flower rose-purple, a little drooping, about $\mathrm{I}$ in. long, the lip prominently bearded. June. Newfoundland to Fla. and westward. Fig. 163. A related species, Pogonia divaricata, found from N. J. southward along the coast, differs in the lip being crested, and in being greenish with purple stripes.

\section{r64. WHORLED POGONIA. ISOTRIA.}

Woodland orchids with a rootstock and fibrous roots. Leaves in a whorl of 5 at the top. Flowers I or two, greenishyellow and borne above the whorl of leaves. The flower is crested but spurless. Fruit an oblong erect pod.

Whorled Pogonia. Isotria verticillata. (Pogonia verticillata.) Not over I ft. high. Leaves broadest towards the pointed tip, I-3 in. long, stalkless. Flower solitary, sometimes nodding, on a stalk about $3 / 4$ in. long. The three outer 

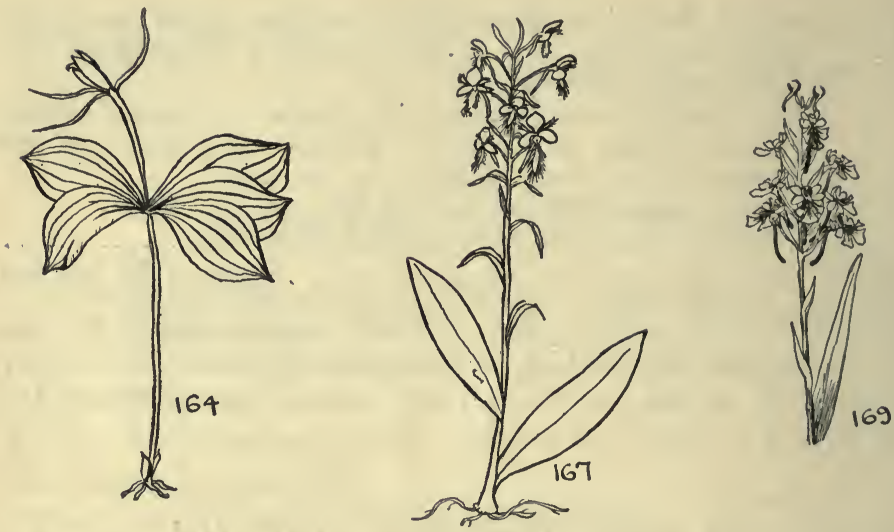

segments of the flower very narrow, about $\mathrm{I} 3 / 4 \mathrm{in}$. long, dark purple, much exceeding the lip. Lip crested, greenishyellow. Pod I in. long. June. Ontario to Fla. west to Mich. and Ind. Fig. I64. A related form, Isotria affinis, which differs in being smaller and in having the outer segments of the flowers about the length of the lip is rare and local in New England, N. J. and Pa.

\section{FRINGED ORCHIS. BLEPHARIGLOTTIS (HABENARIA.)}

Tall leafy-stemmed showy orchids, mostly growing in moist places, with fleshy or thickened roots. Flowers usually several in a terminal spike, between each flower of which there is usually a leafy bract. See Figs. I67-I70. Lip conspicuously fringed or finely toothed, sometimes 3-divided and each of the divisions fringed. See Fig. I70.

Flowers orange or orange-yellow

Spur about $1 / 4$ in. long, shorter than the lip $\ldots \ldots \ldots \ldots \ldots \ldots$ ...................... Yellow-crested orchis no. 166 Spur over I in. long, twice as long as the lip ............... $\ldots \ldots \ldots \ldots \ldots \ldots \ldots$ Yellow-fringed orchis no. 167 Flowers not orange or orange yellow

Flowers pure white $\ldots \ldots \ldots \ldots$. White-fringed orchis no. 168 
Flowers not pure white.

Flowers lilac or purple.

Segments of the 3-parted lip merely cut-toothed; flowers violet purple ............... Purple orchis, no. 169

Segments of the 3-parted lip deeply fringed; flowers lilac, fragrant $\ldots \ldots \ldots \ldots \ldots$ Purple-fringed orchis, no. I7o Flowers greenish-yellow ......... Ragged orchis, no. I7I I66. Yellow-Crested Orchis. Blephariglottis cristata. Stem 8-20 in. high, angled. Leaves lanceolate, sharp-pointed, 2-8 in. long, scarcely $\mathrm{I}$ in. wide. Flowers bright orange, the lip deeply fringed but not 3 -divided. Spur about $1 / 4$ in. long. Summer. Bogs or meadows, N. J. to the Gulf.

I67. Yellow-Fringed Orchis. Blephariglottis ciliaris. From $\mathrm{I}-2 \mathrm{I} / 2 \mathrm{ft}$. high. Leaves lanceolate $4-8 \mathrm{in}$. long, $\mathrm{I} / 2-\mathrm{I} / 2 \mathrm{in}$. wide. Flowers orange-yellow in a dense spike that is often 3 in. thick. Lip deeply fringed, but not 3 -divided, much exceeded by the long spur. Summer. Meadows, New England to Fla. and westward. Fig. I67.

I68. White-Fringen Orchis. Blephariglottis blephariglottis. Similar to the preceding in foliage. Flowers pure white, smaller than the preceding. Summer. Newfoundland to Fla. and westward, mostly in bogs and meadows.

I69. Purple Orchis. Blephariglottis peramoena. Stem I$2 \pi / 2 \mathrm{ft}$. Leaves acute at the tip $4-8 \mathrm{in}$. long, $I / 2-\mathrm{I} / 2 \mathrm{in}$. wide. Flowers showy, violet-purple. Lip 3-divided, the fan-shaped divisions cut-toothed but not truly fringed. Summer. Wet meadows, N. J. to Ala. and Tenn. west to Ill. and Mo. Fig. I69.

I70. Purple-Fringed Orchis. Blephariglottis psycodes. Sometimes as high as $3 \mathrm{ft}$. Leaves oval or lance-oval, 2-Io in. long, $\mathrm{I}-3$ in. wide. Flowers lilac-purple, fragrant, the lip deeply 3-divided, the fan-shaped divisions fringed, especially the 2 outer ones. Spur nearly I in. long, thickened at the tip. Summer. Moist places, Newf. to N. Car. and Tenn. west to Minn. Fig. I7O. A related species Blephariglottis grandiflora, differing in having all the segments of the 3-divided lip equally fringed, and in its larger flowers, is found from eastern Canada to N. Car.

I7. Ragged Orchrs. Blephariglottis lacera. From $\mathrm{I}-2 \mathrm{ft}$. Leaves $5^{-8}$ in. long, $\mathrm{I}-\mathrm{I} 1 / 2$ in. wide. Flowers greenish-yellow, 

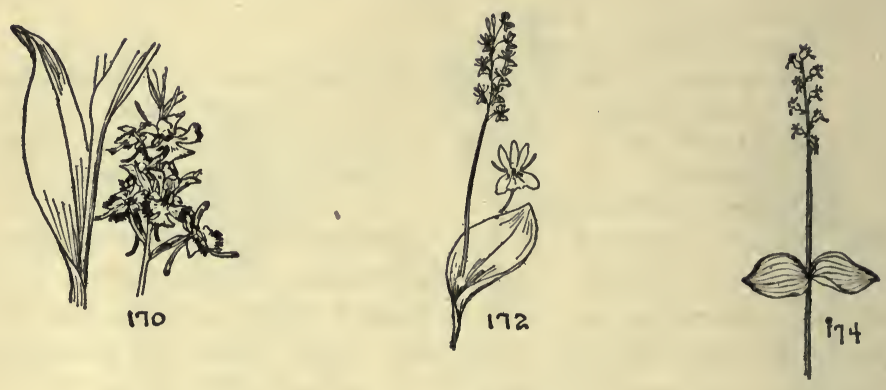

in a loose spike. Lip deeply 3-divided, each of the narrow divisions deeply fringed. June-July. Moist places, Newfoundland to Ga. and westward. A related prairie species, Blephariglottis leucophaea, is found from Nova Scotia to Ky. and westward, but not along the coast in the Middle Atlantic States.

\section{I72. ADDER'S-MOUTH. MALAXIS.}

Slender woodland orchids with solid bulbs. Leaf solitary. Flowers small, greenish-white, not showy, in a terminal raceme. Lip heart-shaped or eared at the base, often minutely toothed on the margin. Fruit an oval or nearly round pod. Adder's-mouth. Malaxis unifolia. (Microstylis unifolia.) Stem striped, mostly less than Io in. high. Leaf solitary, clasping the stem near the middle, oval or roundish $I-2 \mathrm{I} / 2$ in. long. Flower-cluster I-3 in. long, the flowers greenish, about $1 / 8$ in. long. July. Newfoundland to Fla. and westward. Fig. I72. A related species, Malaris monophylla, differs in having a basal leaf, and a more slender flower-cluster. It is found from Quebec to Pa. and westward.

\section{I73. TWAYBLADES. OPHRYS. (LISTERA.)}

Small slender orchids with fibrous or thickened roots but no bulb. Leaves 2, opposite, about the middle of the stem. 


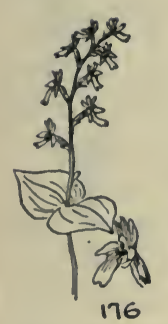

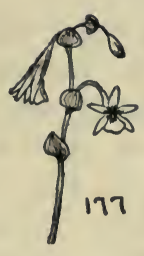

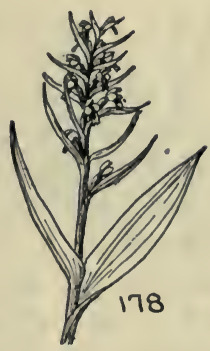

Flowers greenish-yellow or purplish, small, in a terminal raceme. Fruit and ovoid pod that is sometimes broadest towards the tip. Nos. I60 and I6I are also called Twayblades.

Stalk of the flower cluster smooth among the flowers; flowers about $1 / 5$ in. long ................... Twi-foil, no. 174 Stalks of the flower clusters sticky-hairy throughout; flowers longer.

Leaves narrowed towards the base, usually less than I in. long ..

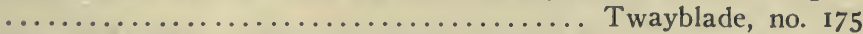

Leaves broad at the base, nearly kidney-shaped, mostly more than $I$ in. long ................. Twayblade, no. I76 I74. Twi-foil. Ophrys cordata. Slender, nearly smoothstemmed orchid scarcely I $\mathrm{ft}$. high. Leaves pointed at the tip, broad at the base, $1 / 2-1$ in. long. Flowers purplish, the cluster 4-20-flowered, its stalk quite smooth among the flowers. Fruit ovoid, usually drooping. July. Labrador to N. J. and westward, usually in moist woods. Fig. I74.

I75. Twayblade. Ophrys australis. Somewhat like the preceding but with larger yellowish green flowers with purple stripes, and with the leaves narrowed towards the base. Summer. Ontario and from N. Y. and N. J. to the Gulf, in bogs. I76. TWAYBLADE. Ophry's convallarioides. Like the first but with fewer flowers and the stalk of the cluster sticky-hairy its entire length. Flowers nearly $1 / 2$ in. long, greenish-yellow. Leaves nearly round, very broad towards the base, about $\mathrm{I} / 2$ in. long. July. Newfoundland to $\mathrm{Vt}$. west to Alaska and Mich., mostly in the highlands. Fig. I 76. 


\section{I77. NODDING POGONIA. TRIPHORA.}

A woodland orchid with fleshy tuberous roots and leafy stems. Flowers nodding, pale-purple, one from near each leaf. Lip not crested but slightly crisped or roughened. Nodding Pogonia. Triphora trianthophora. (Pogonia trianthophora.) Not over 8 in. tall. Leaves alternate, oval, scarcely an inch long, usually clasping the stem. Flowers solitary at each leaf, about $3 / 4$ in. long. Fruit a drooping pod, about $1 / 2$ in. long. August. New England to Fla. and westward. Fig. I.77.

\section{I78. BRACTED GREEN ORCHIS. COELOGLOSSUM.}

Tuberous, woodland orchids with leafy stems. Flowers greenish, in a terminal, profuse spike, from between each flower of which there arises a leafy bract that is much longer than the flower. Lip not crested or fringed, but 2-3 toothed, Spur shorter than the lip.

Bracted Green Orchis. Coeloglossum bracteatum. (Habenaria bracteata.) Stem $3 / 4-2 \mathrm{ft}$. high, leafy. Leaves $2-5$ in. long, oval to lanceolate, diminishing towards the inflorescence into bracts. Flower clusters 3-5 in. long, usually looseflowered. Summer. Nova Scotia to N. Car. and westward. Fig. I78.

\section{I79. GREEN ORCHIS. PERULARIA.}

Fibrous-rooted orchids of moist soil, with a leafy stem. Flowers in a spike, the flowers of which are between bracts. Spur longer than the lip.

Green Orchis. Perularia flava. (Habenaria flava.) From I-2 ft. high. Leaves mostly lanceolate 4-I2 in. long, and narrowed both ends. Flower cluster $2-6$ in. long, greenishyellow. Flowers about $1 / 2$ in. long. Pod about $1 / 3$ in. long. July. Nova Scotia to Fla. and westward. Fig. I79. 

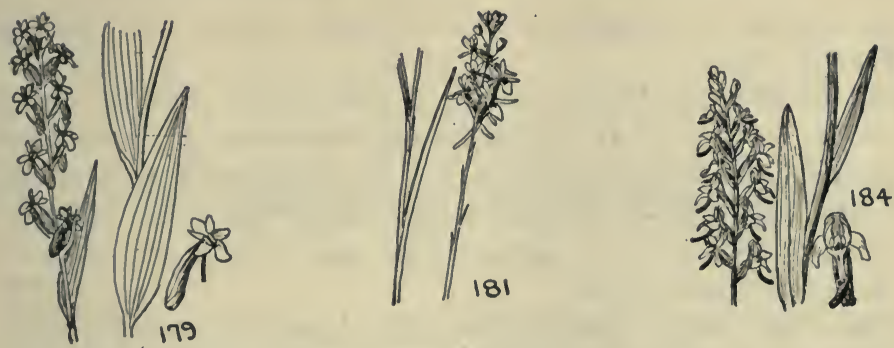

I80. GYMNADENIOPSIS. (HABENARIA, IN PART.)

Fibrous- or slightly tuberous-rooted orchids of moist woods or bogs, with leafy stems. Flowers in a terminal spike, between each flower of which is a leaf-like bract mostly shorter than the flower. Lip not fringed or crested, sometimes 3toothed, slightly roughened in the second species. Spur long and slender, much longer than the lip.

Flowers white.

i8i. Gymnadeniopsis niven. No common name. Stem leafy, angled, about I ft. high. Leaves-nearly linear, 4-7 in. long, diminishing upward into bracts. Spike about 3 in. long, the flowers small, long-spurred. Lip not 3 -toothed. August. N. J. to Fla. and Ala.; in bogs. Fig. I8I.

Flowers orange.

182. Gymnadeniopsis integra. No common name. From I-2 ft. high, the stem angled. Leaves I-3, nearly linear, 2-8 in. long, much smaller above. Spike $\mathrm{I}-3$ in. long, the spur not much longer than the lip. July. In bogs from N. J. to the Gulf. A related species. Gymnadcniopsis clavellata, differing in having the basal leaf broadest towards the tip and in having greenish-white flowers with long, curved spurs, is found in moist places from Newfoundland to Fla. and westward.

\section{LIMNORCHIS. (HABENARIA, IN PART.)}

Fleshy-rooted orchids of bogs or wet woods with leafy stems and white or greenish flowers in a terminal spike. Lip 
not crested or fringed or toothed. Spur shorter than the lip. Flowers white.

184. Northern White Orchis. Limnorchis dilatata. Stems round, leafy, I-2 ft. high. Leaves lanceolate 4-IO in. long, scarcely an inch wide. Spike 3-9 in. long, the flowers small, white. Lip usually a little longer than the spur. Summer. Nova Scotia to N. Y. west to Ore. and Alaska. Fig. I84. Flowers greenish-yellow.

185. Northern Green Orchis. Limnorchis hyperborca. From $3 / 4-3 \mathrm{ft}$. tall. Leaves lance-oval $3-\mathrm{I} 2 \mathrm{in}$. long, $\mathrm{I} / 2-\mathrm{I} / 2 \mathrm{in}$. wide. Spike $3-8$ in. long. Spur nearly as long as the lip. June-July. Greenland to N. Y. and N. J. west to Colo. and Ore. 
No. 186.

\section{Herbs with Netted-Veined Leaves (Nos. 187-96r.)}

(Dicotyledonae).

All the plants in this group, making up much the largest part of our flora, have one or sometimes several main veins to their leaves, but except in a few instances noted below, none of these is parallel. There is always some sort of a network arrangement of the leaf-veining, lateral branches of the principal veins criss-crossing, sometimes rather regularly, but often without apparent pattern.

The flowers in this large group of netted-veined herbs may be of any color, but all agree in having the parts of the flower (petals etc.) in fours or fives, or multiples of these numbers. Some families always have four petals, as in the mustard and its relatives, for instance, others always five, as in the rose family. In some cases, as explained at number 244, there are no petals, and in the false mermaid, number 382 , there are only three.

In such a large group of flowering plants it is obvious that some general scheme of separating them must be devised, and a major one is presented to us at once. All of them must either be erect plants on the one hand, or climbing or twining vines on the other, so we may begin separating them thus:

Plants not climbing, or twining, or sprawling over the ground. Sometimes they may be weak and prostrate, but never true

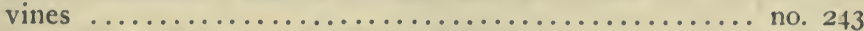

Climbing, or twining, or sprawling vines $\ldots \ldots \ldots \ldots \ldots$ no. 187

No. 187 .

Vines (Nos. 188-242.)

Vines are often many feet long, like the morning glory, or short, like the ground nut, but all these have herbaceous 
stems,-not woody ones, like the grape. A few partially woody vines are noted in their proper places. Sometimes they scramble over fences and walls, like the Virgin's Bower and Mikania, or again, they may sprawl over the ground, as the wild Convolvulus so often does. Others go straight up tree trunks, or clamber over bushes, like the Dodder.

A curious prolongation of the leaf, or of the stem, but neither one nor the other, is found in many vines, - a tendril. Often coiled, usually fine and thread-like, tendrils are of considerable use to vines. Pictures of tendrils are shown at figures I88-I9I and 217-224.

All our herbaceous vines may be divided into two groups, and there is one curious leafless sort, that, by its parasitic habit and leafless yellow stems, differs from all other vines in the region. (Two parallel-veined herbaceous vines are treated at nos. I3I and I32, and the Money Wort, a vine-like herb at no. 468.) The vines may be separated thus:

Leaves compound .............................. 214

A leafless, sprawling yellow-stemmed vine, always firmly attached (parasitic) to other plants ................ Dodder no. 242 Leaves simple

Vines without tendrils .................... no. 192

Vines with tendrils (see figs. I88-19I)

Flowers large, solitary and showy .... Passion-flower no. I 88 Flowers small; in clusters, never solitary .... Gourds no. 189

\section{I88. PASSION-FLOWER. PASSIFLORA.}

High climbing vines with tendrils, and large, lobed leaves. Flowers usually arising at the base of the leaf-stalk, never more than one at such a joint. Flowers with a double or triple row of thread-like organs, thus appearing fringed. Fruit a berry. (Passifloraceae.)

Passion-flower or Passion-vine. Passiflora lutca. Frequently climbing up to Io feet, and quite smooth. Leaves broader than long, with three smooth, marginal lobes, and heart-shaped at the base. Flower greenish-yellow, about 3/4 inch across. Berry round, purple, about $1 / 2$ inch in diameter. $\mathrm{Pa}$. to Ill., and Mo., south to Fla. and Texas. June. Figure I88. A related species, with a purplish flower, toothed leaves, 

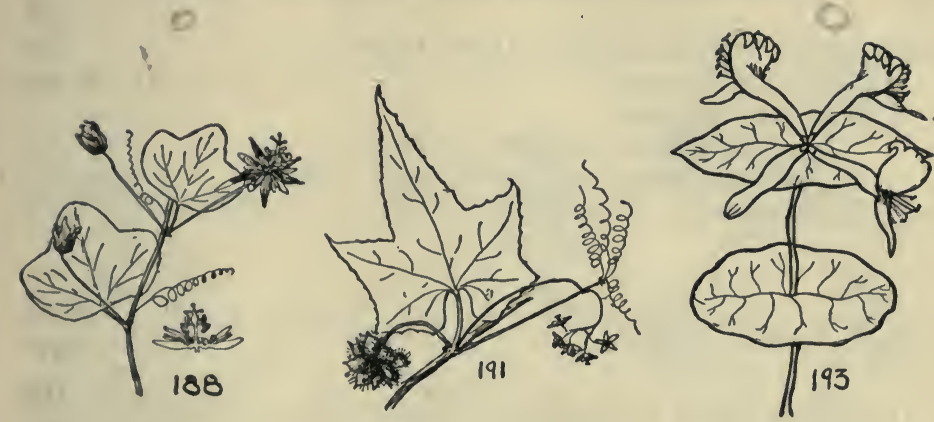

and yellow berry, known as Passiflora incarnata is found from Virginia to Missouri, and southward.

189. THE GOURDS. CUCURBITACEAE.

Herbaceous vines, including the pumpkin, melon, cucumber and squash. Leaves alternate, generally lobed; tendrils branched. Flowers in our species small and clustered, followed by a prickly or bristly fruit.

Leaves with long sharp pointed lobes, fruits solitary, 2 inches long $\ldots \ldots \ldots \ldots \ldots \ldots \ldots \ldots \ldots \ldots \ldots \ldots \ldots \ldots \ldots \ldots \ldots$ Nock apple no. 190

Leaves merely angled, or short lobed, fruits 3-10 together, about $1 / 2$ inch long ................... Star cucumber no. I9I 190. Mock Aprle. Micrampelis lobata. (Echinocystis lobata.) An annual, weak, herbaceous vine, climbing over bushes. Leaves heart-shaped at the base, on rough stalks, deeply lobed with sharp-pointed lobes. Flowers numerous, white, followed by an ovoid prickly fruit about 2 inches long. Nova Scotia to Ontario and Montana, south to Va., Ky., and Texas. August. igi. Star Cucumiber. Sicyos angulatus. Annual herbaceous vine with sticky stem. Leaves nearly round, sometimes \& inches across, rough, heart-shaped at the base, angled, or shallowly lobed. Flowers white, not so numerous as in the preceding, the clusters long-stalked. Fruits clustered 3-10 together, about 1/2 inch long, hairy and prickly. Quebec to Fla., west to So. Dak., Kan., and Texas. July. Figure I9I. 
I92. Vines without tendrils (nos. I93-2I3).

Leaves all alternate ....................... no. 202

Leaves all opposite

Uppermost leaves decidedly stalked ........... no. 197

Uppermost leaves with their bases connected, the stem thus appearing to pass through them .... Honeysuckles no. 193

\section{I93. HONEYSUCKLES. LONICERA.}

Climbing vines with showy, tubular, mostly unsymmetrical terminal flowers and with the uppermost pair of leaves having their bases joined. Leaves always without teeth on the margin. Fruit a berry. Stems often woody below and herbaceous towards the tip. (Caprifoliaceae.)

Flowers decidedly unsymmetrical, the top slit into 2 irregular divisions (see Figs. 193 and 194.)

Flower smooth inside ........... Italian Honeysuckle no. 193 Flower hairy inside

Leaves hairy on the under side, flowers yellow ...................... Rough Woodbine no. 194

Leaves smooth both sides, bluish below; flowers tinged with purple .................. Small Woodbine no. 195

Flowers nearly symmetrical, the top slit into 5 nearly regular divisions (see Fig. 196) ...... Trumpet Honeysuckle no. 195 I93. Italian Honeysuckle. Lonicera Caprifolium. Climbing over bushes, the stems smooth. Lower leaves without stalks, or short-stalked. Flowers in practically stalkless clusters, purplish outside, white within, I-I $1 / 2$ inches long. Berries red. N. Y. and N. J. to Mich. and Mo., and southward. Native of Europe. May. Fig. 193.

I94. Rough Woodbine. Lonicera hirsuta. Twining, with sticky and hairy stems. Lower leaves short-stalked, rarely stalkless, hairy beneath and on the edge. Flowers in stalked clusters, hairy inside, orange-yellow, or reddish. Vt. and Ontario to Manitoba, and from $\mathrm{Pa}$. to Mich. June. Fig. I94. A somewhat similar species, but with smooth branches and no hairs on the edges of the leaves, Lonicera glaucescens is found from Ontario to Alberta, Pa., Ohio and Neb.

I95. Small Woodbine. Lonicera dioica. Whole plant smooth, the stem 3-Io ft., sometimes nearly chrubby. Leaves very 

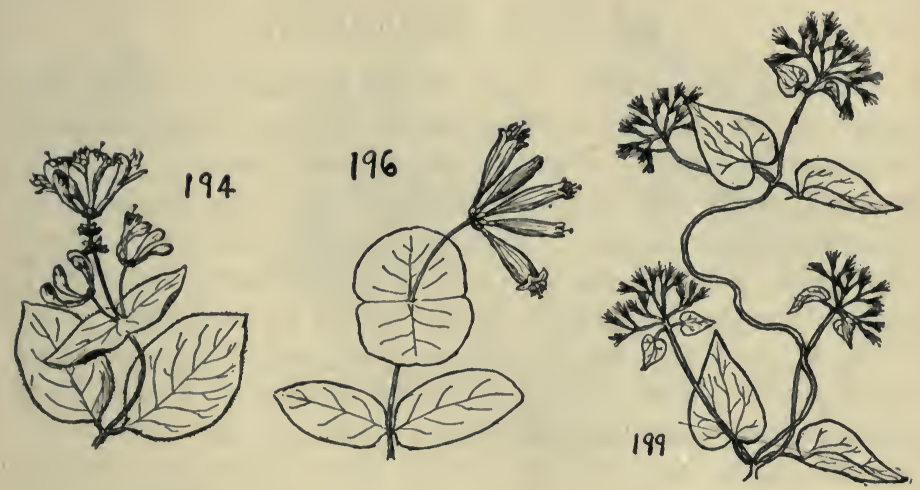

bluish beneath, $I \frac{I}{2}-3$ inches long. Flowers in a stalked cluster, yellow-green, tinged with purple. Quebec to Manitoba south, mostly in the mountains to No. Car., west to Ohio and Mo. May. A related species, Lonicera Sullivantii, with large pale yellow flowers, is found from Ontario to Wis. and Minn., south to Ohio and Tenn.

196. Trumpet Honeysuckle. Lonicera sempervirens. High climbing and with nearly or quite smooth stems. Leaves very bluish-green beneath, dark green above. Flower with a long tube, split at the top into 5 nearly regular parts, $\mathrm{I}-\mathrm{I} \mathrm{I} / 2$ inches long, yellow or scarlet. Me. to Fla., N. H., Neb. and Tex. Summer. Fig. 196. Sometimes the Japanese honeysuckle Lonicera japonica, a very fragrant garden species, escapes from cultivation on the Atlantic seaboard. Some of its flowers are not terminal, and all its leaves are stalked.

197. Uppermost leaves decidedly stalked.

Leaves deeply lobed $\ldots \ldots \ldots \ldots \ldots \ldots \ldots \ldots$. Hop no. 198

Leaves faintly, or not at all lobed

Flowers very numerous, in small compact heads ............

Climbing hempweed no. 199

Flowers not numerous, never in compact heads

Lobes of the tubular flower nearly erect .. Sand vine no. 200

Lobes of the tubular flower decidedly spreading ..........

Running Milkweed no. 20I 


\section{I98. HOP. HUMULUS.}

Twining vines with very rough herbaceous stems and deeply lobed, sharply toothed leaves. Flowers minute, green, in clusters, some of them aromatic and resinous, followed by the familiar hop. (Cannabinaceae.) The only species is the Hop. Humulus Lupulus. Often 25 feet long, the stem covered with stiff reflexed hairs. Leaves nearly round or oval in outline, deeply 3-7 lobed. Nova Scotia to Manitoba, south to N. Y. and Ga., west to Kan., Ariz. etc. Summer. Much cultivated and often escaping but found also as a wild plant. For a related plant see no. 305 .

\section{CLIMBING HEMPWEED. MIKANIA.}

Herbaceous, smooth-stemmed vine, climbing often 5-I2 feet, over bushes. Leaves deeply heart shaped at the base, sharp-pointed at the tip. Flowers very numerous in compact heads. (Compositae.) See No. 8og. The only species is the Climbing Hempweed. Mikania scandens. Leaves stalked. Heads of flowers in compound clusters, at the ends of the branches, whitish or pinkish. August. Me. to Ontario, Fla. and Tex. Fig. I99.

\section{SAND VINE. GONOLOBUS.}

High climbing, herbaceous vines, often hairy toward the top. Leaves heart-shaped at the base. Flowers with a very short tube, the lobes erect, or nearly so. Fruit a smooth pod, the seeds tailed. (Asclepiadaceae.) Our only species is the Sand Vine. Gonolobus lacvis. Leaves broad at the base, gradually tapering to the tip, the margins smooth-edged, 3-7 inches long. Flowers between the leaf-stalks, about $1 / 4$ inch long, whitish, followed by a pod 4-6 inches long. July. Pa. to I1l., Kan. and Tex. Fig. 200. A somewhat similar vine, Cynanchum nigrum, with dark purple flowers, and smaller pods is found from Mass. to Pa. and Ohio. It is a native of Europe. See also no. 696. 
A GUIDE TO THE WILD FLOWERS
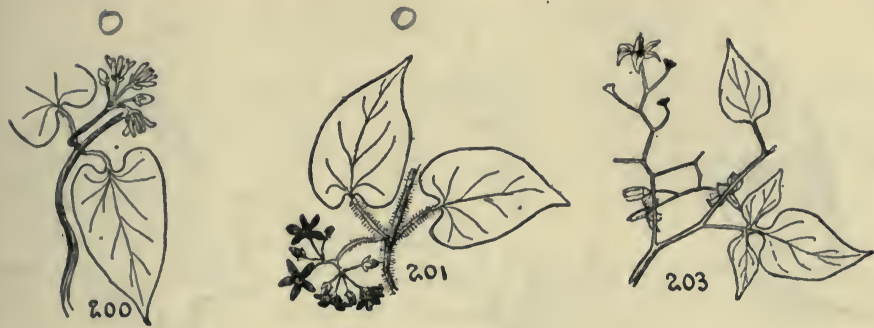

201. RUNNING MILKWEED. VINCETOXICUM.

Similar to the preceding, but with the lobes of the flower decidedly spreading, and in our species the pods rough. (Asclepiadaceae.)

Running Milkweed. Vincetoxicum hirsutum. Stem downy, slender. Leaves heart-shaped at the base, on a hairy stalk. Flowers clustered, brownish-purple to greenish-yellow. Pods 3-5 in. long, roughened and somewhat hairy. Md. to Fla., west to Tenn. Summer. Fig. 201. Other species are known.

202. Leaves all alternate (Nos. 203-213).

Leaves apparently, though not actually compound, merely deeply cleft; flowers usually bluish purple, fruit a berry ...........

Leaves not deeply cleft, often lobed

Flowers small, never tubular, in various kinds of clusters.

Stems prickly-hairy .............. Tear-thumb no. 204

Stems smooth ............... False buckwheat no. 205

Flowers large, tubular, one or a few together, but not in clusters.

Stigma round (see Fig. 207) ..... Morning Glory no. 206 Stigma forked (see Figs. 211, 213) ..... Bindweed no. 209 203. Climbing Nightshade, or Bitter-Sweet. Solanum Dulcamara. (Solanaceae.) A straggling vine scarcely more than $6 \mathrm{ft}$. high, often somewhat woody. Leaves stalked, sometimes undivided, more often deeply 3-cleft, the middle lobe much larger than the side ones. Flowers bluish-purple, rarely white, in clusters, about $1 / 2$ in. long, followed by a bright red oval or round berry. Summer. Nova Scotia to Minn., 

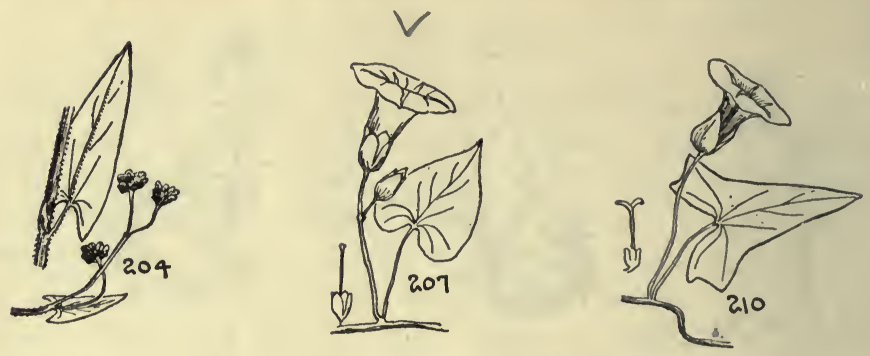

Wash., N. J., Pa. and Kan. Native of Europe. Fig. 203. See also No. 654 .

204. Tear-Thumb. Tracaulon sagittatum. (Polygonum sagittatum.) (Polygonaceae.) Scrambling over bushes, with a 5angled, very rough stem. Leaves arrowhead-shaped $1 \mathrm{I} / 2-3$ in. long, about $1 / 3$ as wide. Flowers scanty, greenish or rose colored, in a terminal cluster. Fruit dry, 3-angled, scarcely $1 / 8$ in. long. August. Nova Scotia, south to Florida and westward. Fig. 204. A related species with halberd-shaped, larger leaves, Tracaulon arifolium, is common from New Brunswick to Minn. and Ga. See No. 294.

\section{FALSE BUCKWHEAT. TINIARIA.}

Climbing or trailing vines with smooth stems. Leaves heart-shaped at the base, pointed at the tip. Flowers small, in clusters and followed by a 3-angled dry fruit. (Polygonaceae.) Four or five species are known, which are distinguished by technical characters. One of the comaruave is False Buckwheat or CoRn Bindweed. T iria Cuni. volvulus. (Polygonum Convolvulus.) A scrambling vine, scarcely $3 \mathrm{ft}$. long, and usually branched, with the flowers greenish, small, and in hanging clusters. Leaves long-stalked, $I^{1} / 2-3$ in. long, narrow pointed at the tip, heart shaped at the base. August. Nearly throughout North America. Native of Europe. See No. 294. 


\section{MORNING-GLORY. IPOMOEA.}

Twining or trailing on the ground. Flowers large, showy, tubular or funnel form, solitary or a few together. Stigma clubshaped or round, fruit a pod. (Convolvulaceae.) See Fig. 207.

Leaves without lobes, stem smooth.

207. Wild Potato Vine. Ipomoea pandurata. With an enormous fleshv root, used by the Indians as we use the sweet potato, to which it is related. Leaves heart-shaped at the base, narrow tipped, 2-6 in. long. Flowers funnel-shaped, I-5 together, white, or with pinkish stripes, $2-3$ in. long. Pod with 2-4 hairy seeds. Summer. Ontario to Florida, Mich., Kan., and Tex. Fig. 207.

Leaves without lobes; stems rough hairy.

208. Morning-Glory. Ipomoea purpurea. An annual vine, 4-Io ft. long, with fibrous roots. Leaves similar to the preceding, but hairy, 2-4 in. long. Flowers also similar to the preceding, but blue, purple, or very rarely white. Mostly as an escape froni gardens. Summer. Nova Scotia to Florida, west to Neb. and Tex. Native of tropical America. Another Morning-glory, Ipomoca hederacea, differing chiefly in having lobed leaves, is found from Maine to Florida, Pa., Neb. and Mex. Native of tropical America.

\section{BINDWEEDS. CONVOLVULUS.}

Similar in general aspect to the Morning-glory, but with generally smaller flowers, and stigmas apparently forked. (Convolvulaccac.) See Figs. 210, 2 I3.

Flowers with 2 leaf-like organs at the base (see fig. 210)

Leaves " plberd-shaped, or arrowhead-shaped (see fig. 210)

Lea ${ }^{\prime}$ halberd-shaped, stems 3 -10 ft.

Hedge Bindweed no. 210

Leaves arrowhead-shaped, stems $\mathrm{I}-3 \mathrm{ft}$.

Leaves oval .................. Low Bindweed no. 212

Flowers without 2 leaf-like organs at the base (see fig. 213) ... Small Bindweed no. $2 \mathrm{I} 3$ 210. Hedge Bindweed. Convolvulus scpium. Leaves slander 

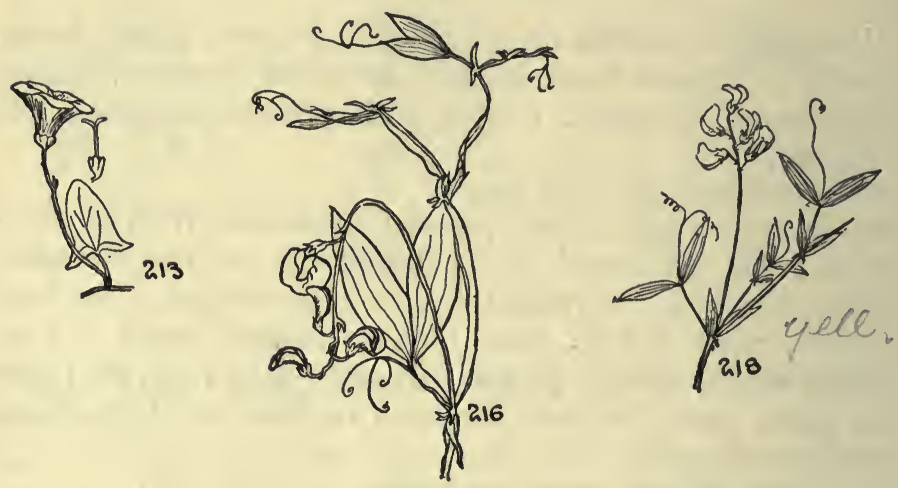

stalked, $2-5$ in. long, triangular in outline, the basal lobes widely-spreading, acute. Flowers solitary, arising from the base of a leaf-stalk, pink, often white striped, or rarely white throughout, 2 in. long. July. Newfoundland to British Columbia, 111., etc. Fig. 2 Io.

2ir. Trailing Bindweed. Convolvulus repens. Lower, and nearly always trailing on the ground, the stem more or less hairy. Leaves stalked, I-2 in. long, not triangular in outline, the basal lobes not widely spreading. Flowers about 2 in. long, white. June-July. Quebec to Florida, and Louisiana, rare or wanting westward.

2I2. Low BindweEd. Convolvulus spithamaeus. Scarcely ever more than I ft. high, weekly trailing. Leaves oval, almost or quite stalkless, I-2 in. long. Flowers white, about 2 in. long. June-July. Nova Scotia to Ontario and Manitoba, south to Florida and $\mathrm{Ky}$.

2r3. Small Bindweed. Convolvulus arvensis. Stems trailing, never more than $2 \mathrm{ft}$. long. Leaves somewhat similar to the first, but smaller. Flowers usually I-4 together, and without the 2 leaf-like organs at the base, pink or white, about $\mathrm{I} I / 2$ in. long. Summer. Nova Scotia to Ontario, and Montana, south to N. J., Kan., etc. Native of Europe and Asia. Fig. 213. 
214. Vines with compound leaves. (Nos. 215-24I.)

Flowers not pea-like ........................ no. 235

Flowers pea-like (see Figs. 218-233) .... Pea Family no. 215 215. PEA FAMILY. FABACEAE. (Nos. 216-234.)

Mostly herbaceous vines in our area, but woody sometimes, as in the garden wistaria, and overwhelmingly so in the tropics, where there are many stout woody pea-like vines that reach the topmost heights of the forest canopy. The leaves are always compound, sometimes with three leaflets, but more often with many. Flowers pea-like, not unlike the sweet pea of gardens, followed by a one-too-many seeded pod (legume) which splits into two parts. See Fig. 233. See also No. 592.

Plants without tendrils (see Figs. 228-233) .......... no. 227

Plants with tendrils (see Figs. 218-224)

Leaf-stalks prominently winged (see Fig. 216)

Leaf-stalks not so winged.

Flowers yellow or white.

Leaflets oval, at least $1 / 2 \mathrm{in}$. broad .. Pale Vetchling no. 217

Leaflets narrower, scarcely $1 / 4$ in. broad, oblong.

Leaflets only I pair, or apparently 2 pairs .............

Meadow Pea no. 218

Leaflets 8-18, not in opposite pairs .Carolina Vetch no. 219

Flowers bluish or purple

Plant of sea beaches and sand dunes .... Beach Pea no. 220

Plants not of the sea beaches

Flowers small, scarcely $1 / 4$ in. long .. Slender Vetch no. 221

Flowers large, usually $1 / 2$ in. long or more

Leaflets strictly in opposite pairs (see Fig. 222) ..... ........................ Wild Pea no. 222

Leaflets scattered, scarcely ever in opposite pairs.

Flowers one or two together, almost stalkless ........

Flowers in stalked clusters

Flower clusters I-sided (see Fig. 224) ...........

Flower clusters not I-sided

Leaflets $I-2$ in. long, stem angled

Cow Vetch no. 224

.............................. Veiny Pea no. 225

Leaflets smaller, stem not angled ..............

Purple Vetch no. 226

2i6. Everlasting Pea. Lathyrus latifolius. Stem $3 \mathrm{ft}$., or more, long, weak, prominently winged. Leaflets a single pair, their stalks winged. Flowers purple to white in stalked clus- 

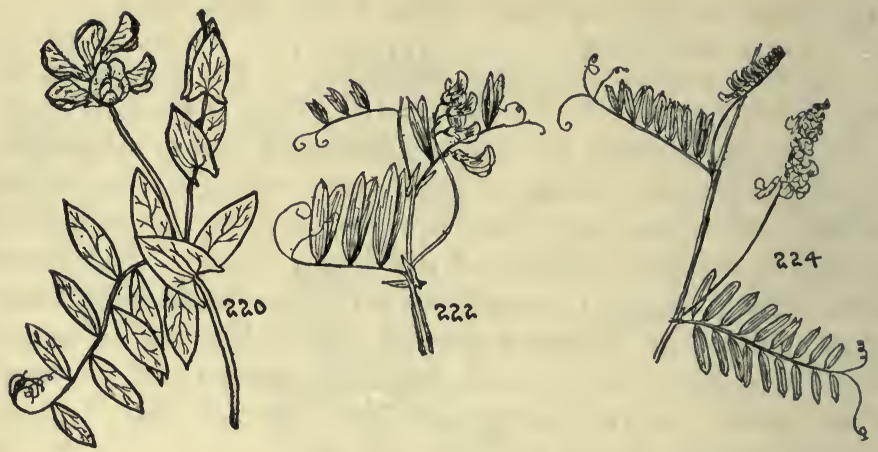

ters. Summer. An escape from gardens. New England to Dist. Col. Native of Europe. Fig. 216.

2i 7. Pale 'Vetchling. Lathyrus ochroleucus. Stem I-21/2 ft. long, slightly angled. Leaflets $3-5$ pairs, I-2 in. long. Flowers yellowish-white, in a long-stalked meagre cluster. Pods scarcely I in. long, smooth. June. Quebec to British Columbia., N. J., Ill., etc.

218. Meadow Pea. Lathyrus pratensis. Stem I-3 ft. weakly climbing. Leaflets only a single pair, but 2 leaf-like stipules, making it appear as with 2 pairs. Flowers more numerous than in the preceding, yellow. Pod $\mathrm{I}-\mathrm{I} / 2$ in. long, smooth. July. New Brunswick, N. Y., New England, and Ontario. Fig. 218.

2ig. Carolina Vetch. Vicia caroliniana. Stem 2-3 ft., climbing or trailing. Leaflets 8-18, scarcely $\mathrm{I}$ in. long, oblong. Flowers nearly white, $1 / 4-1 / 2$ in. long. Pod $3 / 4-11 / 2$ in. long, smooth. June. Ontario to Minn., south to Georgia, Kan., and Miss.

220. Beach Pea. Lathyrus maritimus. Stem nearly prostrate, angled, coarse. Leaflets 6-12, sharp pointed, I-2 in. long, bluish-green. Flowers 6-Io purple and showy, about I in. long. Pod $\mathrm{I}^{\mathrm{T}} / 2-3$ in. long, veiny. Summer. Sea beaches. Labrador to N. J., and shores of the Great Lakes. Fig. 220. 
22 I. Slender Vetch. Vicia tetrasperma. Annual weak vine, scarcely $2 \mathrm{ft}$. long. Leaflets 6-12, thin, oblong, no more than $3 / 4$ in. long. Flowers bluish-purple, about $1 / 4$ in. long, in a meagre cluster. Pods no more than $1 / 2$ in. long, smooth. Summer. Nova Scotia to Florida, west to Ontario and Miss. Native of Europe and Asia. A related species, Vicia hirsuta, with straight-ended leaflets and a hairy pod is found from Nova Scotia to Va., west to Ohio, etc. Also native of Europe. 222. Wild Pea. Lathyrus palustris. Stems angled and mostly winged, I-3 ft. long. Leaflets in $2-3$ directly opposite pairs, $\mathrm{I}-2 \mathrm{I} / 2$ in. long, oblong. Flowers in a meagre cluster, about $1 / 2$ in. long, purple. July. Newfoundland to N. Y., west to So. Dakota, etc. Fig. 222. A related species, Lathyrus myrtifolius, with usually 3 pairs of leaflets is found from New Brunswick to Tenn., and westward.

223. Vetch. Vicia angustifolia. Stem slender, not winged, I-2 ft. long. Leaflets 6-I4, about I in. long, oblong, not in opposite pairs. Flowers purple, only I or 2 together, practically stalkless, almost $3 / 4$ in. long. Pod I-2 in. long, smooth. May-June. Nova Scotia to Florida, near the coast. Native of Europe.

224. Cow Vetch. Vicia Cracca. Stems weak, 2-4 ft. long. Leaflets 8-24, narrow, very sharp, but weak pointed, slightly less than I in. long. Flowers in large, showy, I-sided clusters, about $1 / 2$ in. long, bluish-purple. Pods about I in. long, smooth. July. Nova Scotia to N. Y. and Kentucky, west to Iowa, etc. Fig. 224.

225. Veiny Pea. Lathyrus venosus. Stem 2-3 ft. long, 4angled. Leaflets 8-I4 oval, I-2 in. long, about half as wide. Flowers purple, in a meagre cluster, $\mathrm{I}-23 / 4$ in. long. June. Pods $1 \frac{1}{2}-3$ in. long, veiny. Ontario to N. J., and Georgia, west to Indiana, etc.

226. Purple Vetch. Vicia americana. Stem 2-3 ft., not angled. Leaflets 8-I4 smaller than in the preceding. Flowers scarcely $I$ in. long, bluish-purple. Pods about $I$ in. long, not veiny. June-July. New Brunswick to Ky., west to Manitoba and Arizona. 

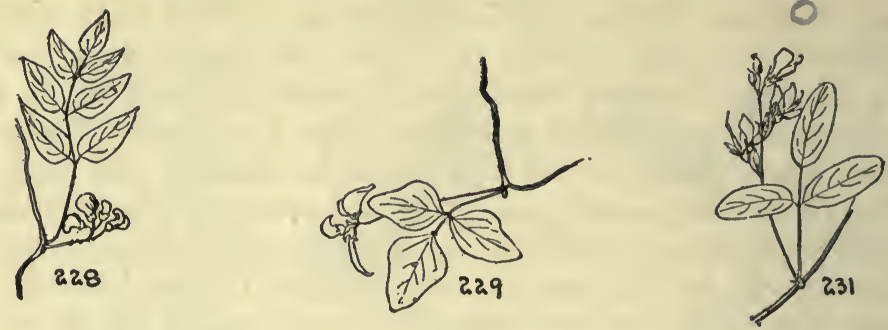

227. Plants without tendrils. (Pea family continued. Nos. 228-234).

Leaflets more than 3 to each leaf (see Fig. 228)

Leaflets 3 to each leaf

Flowers small, scarcely $1 / 2$ in. long.

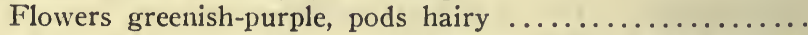

................... Trailing Wild Bean no. 229

Flowers purple, pods smooth, or nearly so $\ldots \ldots \ldots \ldots \ldots$.

Bean Vine no. 230

Flowers reddish-purple, pods slightly hairy ............

Flowers at least I in. long, sometimes more.

Flowers about 2 in. long, very showy $\ldots \ldots \ldots \ldots \ldots \ldots$.

Flowers usually from $I$ to $I \frac{1}{2}$ in. long.

Pods $4-5$ in. long, narrow, smooth $\ldots \ldots \ldots \ldots \ldots \ldots \ldots$.

................ Spurred Butterfly Pea no. 233

Pods about $\mathrm{I}$ in. long, wider and hairy ................

Wild Peanut no. 234

228. Ground-nut. Glycine Apios. (Apios tuberosa.) Climbing, usually $2-6 \mathrm{ft}$. Leaflets $5-7$, oval, I-3 in. long. Flowers in clusters among the leaves, brownish-purple, fragrant, a little more than $1 / 2$ in. long. Pods $2-4$ in. long, not hairy. August. New Bruswick to Florida, west to Ontario, Minn., Kan., etc. Fig. 228.

229. Trailing Wild Bean. Strophostyles helvola. A rather rough-stemmed, branching vine $2-8 \mathrm{ft}$. long. Leaflets often more or less lobed, I-2 in. long. Flowers 3-10 together, greenish-purple, not quite $1 / 2$ in. long. Pod about $2 \frac{1}{2}$ in. long, hairy. Summer. Quebec to Florida, west to So. Dakota and Tex. Fig. 229. A related species, Strophostyles umbellata, with unlobed leaflets and yellowish-pink flowers, is found 

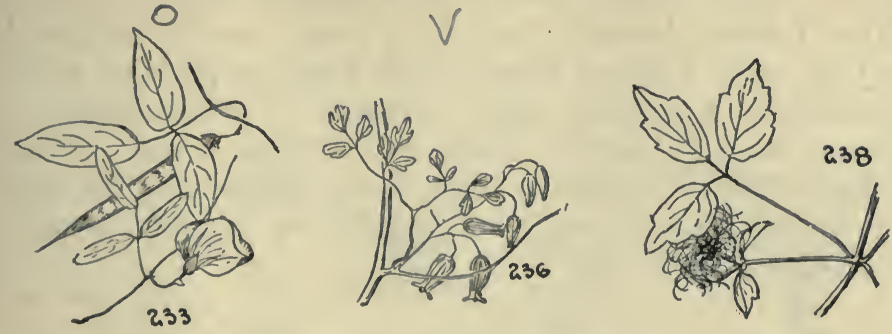

from Long Island to Florida, especially along coastal swamps and in Indiana.

230. Bean Vine. Phascolus polystachyus. Finely hairystemmed vine $5^{-15} \mathrm{ft}$. long. Leaflets oval, sharp pointed, $2-4$ in. long. Flowers in numerous clusters, from among the leaves, purple, about $1 / 3$ in. long. Pods scarcely hairy, $1 \frac{1}{2}$ $21 / 2$ in. long. Summer. Conn. to Fla., Ohio, Neb., etc.

23I. Milk Pea. Galactia regularis. Stems usually matted, I-2 ft. long. Leaflets oval, blunt at the tip, $3 / 4-I / 2$ in. long. Flower clusters on stalks that usually exceed the leaves. Flowers reddish-purple, slightly more than $1 / 2$ in. long. Pods nearly straight, $\mathrm{I}-\mathrm{I} \mathrm{I} / 2$ in. long and somewhat hairy. Summer. N. J. and Penn. to Florida, Kan., and Miss. Fig. 23I. A related species, Galactia volubilis, differing in being finely hairy throughout, is found from Long Island to Fla., Ky., Kan. and Texas.

232. Butterfly Pea. Clitoria mariana. Scarcely more than $3 \mathrm{ft}$. long, the stem smooth or nearly so. Leaflets decidedly short-stalked, nearly oblong, $\mathrm{I}-2$ in. long. Flowers showy, pale blue, about 2 in. long. Pods about $\mathrm{I}^{1} / 2$ in. long, smooth. June. N. J. to Fla., west to Missouri and Texas.

233. Spurred Butterfly Pea. Bradburya virginiana. (Centrosema virginianum.) Stem finely hairy, 2-4 ft. long. Leaflets oval, stalked, prominently veined, $\mathrm{I}-2$ in. long. Flowers $\mathrm{I}-\mathrm{I} \mathrm{I} / 2$ in. long, violet, in meagre clusters. Pod narrow, $4-5$ in. long. Summer. N. J. to Fla., west to Ark. and Florida. Fig. 233.

234. Wild Peanut. Falcafa comosa. (Amphicarpa monoica.) Slender vine, $\mathrm{I}-8 \mathrm{ft}$. long, often branched, the stem rough- 
hairy. Leaflets broadly oval, the 2 lower ones inequilateral, I-3 in. long. Flowers about $1 / 2$ in. long, purplish or white. Pods about $I$ in. long, hairy. Summer. New Brunswick to Florida, west to Manitoba, Neb., etc. A closely related species, Falcata Pitcheri, differs in being more brown-hairy throughout and is found from New England to Virginia, west to So. Dakota, Tenn., etc.

235. Flowers not pea-like; of various shapes. (Nos. 236241.)

Petals or sepals not united to form a slender tube

................. Virgin's Bower and Clematis no. 237

Petals united to form a slender tube . Climbing Fumitory no. 236 236. Climbing Fumitory. Adlumia fungosa. (Fumariaceae.) A weak, herbaceous vine of rich woodlands. Leaves twice compound, very thin and bluish beneath, drooping almost immediately when picked. Flowers numerous in drooping clusters, greenish-purple, the four petals joined to form a narrow tubular spur-like flower. Fruit a dry pod about $I$ in. long. Summer. New Bruinswick to No. Car., west to Ontario, Mich., and Tenn. Fig. 236. (See also No. 557.)

\section{VIRGIN'S BOWER. LEATHER FLOWER. CLEMATIS. RANUNCULACEAE.}

Herbaceous or often partly woody vines with 3 leaflets, white or purplish flowers and plumose or tassel-like fruits. Sometimes simple leaves are found with compound ones. Sepals often petal-like, when petals are lacking as in the leather flower (No. 239), and the curl-flowered clematis (No. 240). See No. 430 for herbaceous relative.

Flowers white, in clusters ............ Virgin's Bower no. 238 Flowers purple or bluish, solitary

Tip of the apparently tubular flower recurved (see Fig. 239)

Petal-like sepals very thick ........ Leather Flower no. 239 Petal-like sepals thin ......... Curl-flowered Clematis no. 240 Tips of the widely spreading petals not recurved ............. ........................ Mountain Clematis no. 24I 

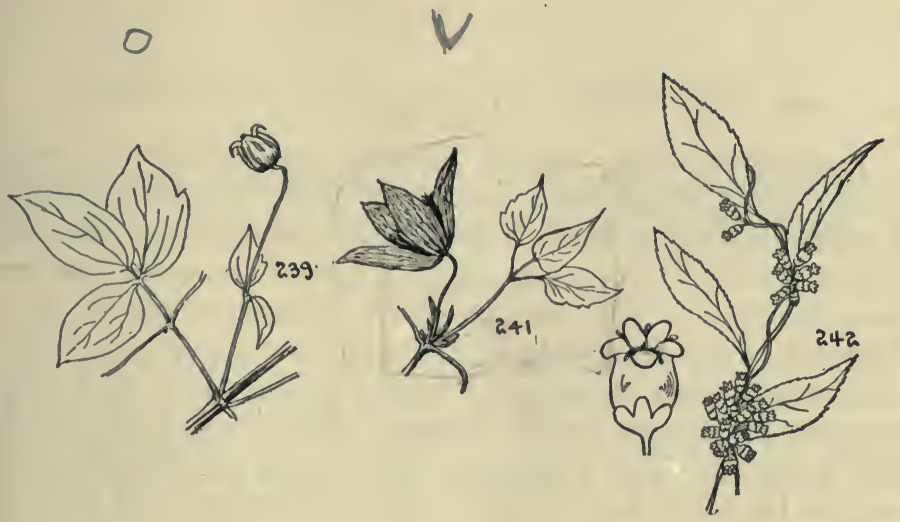

238. Virgin's Bower. Clematis virginiana. Slightly woody, and climbing over bushes, fences, etc. Leaflets 3 , toothed, or more often lobed, all stalked. Flowers in showy white clusters, followed by silky, equally showy fruit clusters. August. Nova Scotia to Georgia, west to Manitoba and Tenn. Fig. 238.

239. Leather Flower. Viorna Viorna. (Clematis Viorna.) Sometimes ro ft. long, and climbing over bushes. Flower solitary, purple, without petals, but its petal-like sepals much thickened. Fruit plumed and brownish. June. Penn. to West Virginia, Georgia and Indiana. Fig. 239.

240. Curl-flowered Clematis. Viorna crispa. (Clematis crispa: Somewhat similar to the preceding, but the petal-like sepals thin. Flowers bluish-purple. Fruits silky, but not plumed. June. Penn. to Missouri, Florida and Texas.

24r. Mountain Clematis. Atragene americana. (Clematis verticillaris.) Trailing or partly climbing, often woody. Leaflets 3 , toothed, or even slightly lobed, or smooth margined. Flowers 2-4 in. broad, the widely spreading purple petals acute at the tip. Fruits showy and plumed. June. Northern Canada to Virginia and westward, mostly in the mountains. Called also purple virgin's bower. Fig. 24I. 
242. DODDER. CUSCUTA. CUSCUTACEAE.

Sprawling vines, always fastened parasitically to other plants from which they get their food. Stems yellowish. Leaves apparently none. Flowers tiny, yellowish, or pinkish. The characters separating the Io species known from our area are more or less technical. The commonest species is DodDer. Cuscuta Gronovii. Growing on shrubs or herbs, the stems yellow to orange. Flowers in tiny clusters. Leaves reduced to minute scales. Summer. Nova Scotia to Florida and westward. Fig. 242 shows the vine attached to an herb, and, at the lower left hand corner, an enlargement of a single flower. 
No. 243.

\section{Plants not Climbing or Twining, Sometimes Weak and Prostrate, but Never True Vines.}

(Nos. 244-925.)

This, the largest single group of herbs in the book, makes up the great bulk of our common wild flowers. There are nearly seven hundred species to be so separated that they may be identified, and certain characters are relied upon for this purpose. While the pictures tell the story of these structural differences, and in most cases will help the reader to identify whatever plant he may have gathered, it is well to keep in mind what these differences are.

One large section is the daisy family, which differs from all other plants in having many small flowers crowded into more or less compact heads. These may have all ray-flowers like the common dandelion (see fig. 9I4), or they may be all tubular like the boneset and ironweed (see figs. 8Io-8I5), or they may have both ray and tubular flowers like the sun flowers and asters (see figs. 854-871, and 904, 906). But whether they have tubular, or ray flowers, or both, these plants of the daisy family all have beneath the flower-head a series of overlapping scales, known as involucral bracts. See the Picture Glossary for a cross-section of a flower of the Daisy family.

Another large section of herbs has practically no petals, and if, as sometimes happens the sepals take the place of petals, then they are not very conspicuous, and usually not showy.

Still other groups have obvious, and often showy, petals, or if these are lacking and consequently replaced by sepals, then these are petal-like, and usually showy. Those that have true petals may have them united to form some sort of a tube, as in the mints and scores of other plants, or they 
may have separate petals, as in the roses and buttercups. A little careful observation. will tell to which of these major types the specimen in hand may belong.

To reduce these structural differences to some sort of a system is the easiest way to find any particular plant. And our primary classification is as follows:

Flowers in compact heads; composed of all ray flowers, of ray flowers and tubular flowers, or only of tubular flowers. These flowers heads always surrounded at the base by a series of overlapping tiny scales, known as involucral bracts. A complete description of the daisy family, and pictures of the flowers will be found at Nos. 810-925 ............ Daisy Family. 110.809

Flowers not in heads; or if so, without the series of overlapping tiny scales beneath them, as in the daisy family. Petals obvious; or if the petals are replaced by petal-like sepals, then these are often showy.

Petals united, often forming a distinct tube, which may be perfectly symmetrical, or unsymmetrical and irregular .... ................................ no. 622

Petals separate, not united to form an obvious tube Flowers unsymmetrical and irregular, often pea-like, violetlike, or spurred, or otherwise not symmetrical (see figs.

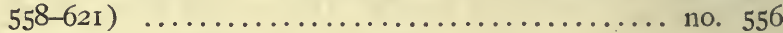
Flowers symmetrical and regular

All the flowers on slender stalklets which arise at the same point and produce a flower cluster known as an umbel (see figs. 527-555) ............... no. 526 Flowers not so arranged .................no. $3^{113}$

Petals none, or very small and inconspicuous, if the sepals are petal-like, not brightly colored, and not showy (often

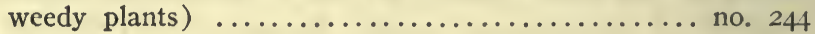

\section{No. 244}

\section{Petals None or Very Small and Inconspicuous. Flowers not Showy.}

(Nos. 245-3I2.)

This is a small group of about fifty different plants, often botanically unrelated, but all characterized by having no petals, or if, as in some cases they do produce petals, these are small, inconspicuous, and not showy. Sometimes, as if to make up for this deficiency of petals, the sepals will be petal-like, but even these are not brightly colored or showy, except in No. 297. Altogether a rather drab assemblage of 
plants, but as many of them are common weeds, they are not to be omitted from the book.

While bright color is nearly always lacking in this group as far as petals or sepals are concerned, other parts of the flower may be decidedly showy and very beautiful. Especially is this true of the plumy stamens of the meadow rues (Nos. 308-3II), the pinkish-red scales of the glasswort (No. 312 ), the white stamens of the burnet (No. 3O7), and many others. Note particularly what part of the plant gives it color. In this group it will not usually be petals or sepals, for when the latter are present, they are often an inconspicuous green or greenish brown. Sometimes they are pink, as in the alpine bistort (No. 247), or crimson, as in the prince's feather (No. 297).

These plants may be grouped thus:

Leafless plant of the salt marshes ......... Glasswort no. 312

Plants with obvious leaves, though these may be small

Stem leaves either actually compound or much divided.. no. 304 Stem leaves neither compound nor divided, but their margins may be toothed or not.

Plants of various situations, but not confined to high alpine summits $\ldots \ldots \ldots \ldots \ldots \ldots \ldots \ldots \ldots \ldots \ldots \ldots \ldots \ldots$ no. 248

Plants confined to high alpine summits, or to the far north

no. 245

245. Plants confined to high alpine summits, or to the far north. (Nos. 246-247.) Consists of only two low herbs with basal and sometimes stem leaves, and curious little sheaths at each leaf-base.

Leaves broad, deeply heart-shaped at the base; flowers greenish in open. loose clusters.

246. Mountain Sorrel. Oxyria digyna. (Polygonaccac.) A low perennial bog herb, with long-stalked basal leaves that are kidney-shaped, or almost round, wholly without teeth, and heart-shaped at the base. Flower cluster erect, branched, rather open, and the individual flowers drooping, greenish, with no petals. Fruit dry, tiny and winged. Greenland and Labrador to Alaska, south to the summits of the White Mountains of New Hampshire and the Rockies. August. 

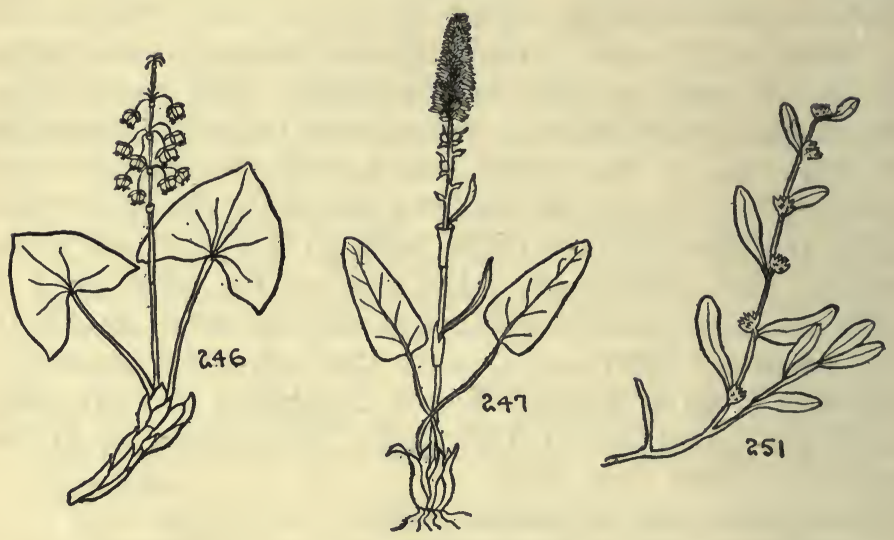

Fig. 246. (See No. 294.)

Leaves narrow, scarcely notched at the base; flower cluster pinkishwhite, close, and finger-shaped.

247. Alpine Bistort. Bistorta vivipara (Polygonum viviparum.) (Polygonaceac.) An erect perennial herb, with basal and stem leaves, the lower long-stalked, the upper almost stalkless. Not over Io in. high, usually half that. Leaves narrow, I-8 in. long, smooth. Flowers pinkish white, in a long stalked finger-shaped, close, cluster, without petals. Fruit tiny, dry, slightly 3 -angled. In bogs and mountain fell-fields. Greenland and Labrador to Alaska, south to the summits of the White Mountains, and of the Rockies. July. Fig. 247.

248. Plants of various situations but not confined to high alpine summits. (Nos. 249-303.)

Plants of dry woods, roadsides, fields, or waste places (largely

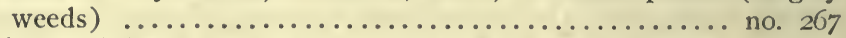

Plants of fresh water ditches, swamps or moist places ........

Plants of salt marshes, sea beaches or sand dunes 
249. Salt marsh, sea beach or sand dune plants with greenish flowers and no petals. (Nos. 250-256.)

There are only seven different sorts which may be divided thus:

Plants erect, at least 6 in. high, usually more.

Prickly and fleshy, all the leaves prickle-tipped ............

........................................ Saltwort no. 250

Neither prickly nor fleshy, leaves blunt ...............

....................... Sea-beach Atriplex no. 25I

Plants prostrate, hugging the ground, or weak.

With a milky juice; leaves broadest at the middle ..........

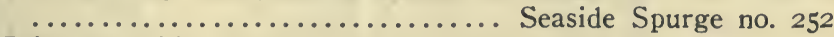

Juice not milky; leaves broadest towards the tip ............

Plants of the salt marshes.

Sea Purslane no. 253

Stems usually reddish or yellowish, 2-10 ft. tall ...........

Stems green, mostiy I-3 ft. tall.

Salt-marsh Water-hemp no. 254

Leaves narrow, linear ........... Low Sea-blite no. 255

Leaves broad, arrowhead-shaped ......... Fat-hen no. 256

250. Saltwort. Salsola Kali. (Chenopodiaceae.) A stout branched annual usually about I 8 in. high, with pricklepointed leaves that are swollen and nearly succulent at the base. Leaves less than an inch long, the prickle yellowish. Flowers solitary, in the joints of the leaf and stem, greenish. Sea beaches from Cape Breton Island to Florida. August. A related species, $S$. pestifer, is similar, but its leaves are reddish. It inhabits waste places nearly throughout America, and came from abroad. (See No. 282.)

25I. Sea-beach Atriplex. Atriplex arenaria. (Chenopodiaccae.) A silvery-scurfy annual, usually much branched, mostly erect or weak, but not prostrate. Leaves $1 / 2-\mathrm{I} / 2$ in. long, narrowed at the base, blunt at the tip. Flowers in small clusters, much shorter than the leaves from the base of which they appear. Sea beaches, New England to Florida. August. Fig. 25I. (See No. 282.)

252. Seaside Spurge. Chamaesyce polygonifolia. (Euphorbia polygonifolia.) (Euphorbiaccac.) Hugging the hot sand of sea beaches. Plant with opposite narrow leaves, and a milky juice. Leaves a little oblique at the base, not over $3 / 4$ in. long. Flowers greenish yellow, usually solitary at the leaf-base. The 

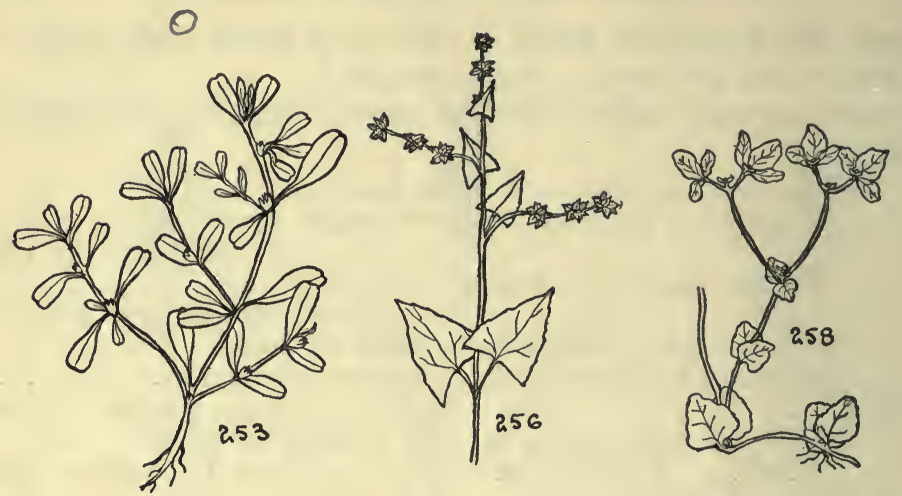

whole plant not over 8 in. long, usually less. Sea beaches along the coast, and along the shores of the Great Lakes. July. See also Nos. 268, 278, 4I9, 447, and 528-530.

253. Sea Purslane. Sesuvium maritimum. (Ai Not hugging the ground, but merely weakly procumbent. Foliage green, the leaves opposite, without teeth, broadest towards the tip, which is usually notched, about $3 / 4$ in. long. Flowers pinkish to purplish about $\frac{1}{1 / 6}$ in. long, solitary at the leaf base. Sea beaches, and moist brackish shores. Long Island to Florida. August. Fig. 253.

254. Salt-marsi Water-hemp. Acnida cannabina. (Amaranthaceae.) A tall erect plant with partly fleshly stem often I in. in diameter, sometimes reddish or yellowish. Leaves alternate, narrow, pointed both ends, about 4 in. long, the lower distinctly stalked. Flowers greenish, in long slender unbranched clusters I-5 in. long. Plant sometimes Io ft. high. Salt marshes, and occasionally ascending into fresh water streams, N. H. to Florida. July.

255. Low Sea-blite. Dondia maritima. (Suacda maritima.) (Chenopodiaceac.) Low rather weak branched annual herb with bluish or grayish-green foliage. Leaves $1 / 2-I$ in. long, narrow, fleshy, broadest towards the stalked base. Flowers usually solitary at the base of the upper leaves, occasionally in a small cluster, not over 1/6 in. long, greenish. Seed brownish red. On wet sea beaches, stony shores, and salt marshes from Quebec southward. August. A related species, D. line- 
aris, has green foliage and black seeds, and is found in salt marshes from Nova Scotia to N. J. and Tex. (See No. 282.) 256. Fat-hen. Atriplex hastata. (Chenopodiaceae.) A scurfy greenish or purplish herb, I-3 ft. tall, with broad arrowhead-shaped wavy-margined leaves I-5 in. long, stalked. Flowers in interrupted clusters, or the latter bunched at the base of a leaf-stalk. Salt meadows, but sometimes in waste places. Nova Scotia to So. Car., and westward. July. Fig. 256. A related species, A. rosea, which often has reddish foliage, and leaves not arrow shaped is found in waste places from Nova Scotia to N. Y. and N. J., and is a native of Europe. (See No. 282.)

257. Plants of fresh water ditches, swamps, or moist places. (Nos. 258-266.)

(Note: Salt marsh species occasionally travel up fresh water streams. Look out particularly for the Salt-marsh Water-hemp, no. 254)

There are eight herbs in this group, of diverse habit and relationship, but all alike in having greenish, inconspicuous flowers, growing in moist or wet places, and in having undivided leaves. They may be identified thus:

Low prostrate plant with nearly round leaves

\section{Erect plants}

Leaves without marginal teeth, sometimes wavy-margined

Flowers in close, finger-shaped clusters

Leaves broad, heart-shaped at base ... Lizard's-tail no. 259 Leaves narrow, pointed at the base

Mild Water-pepper no. 260

Flowers in open loose clusters, the individual flowers on small drooping stalks ................. Water Docks no. 26I

Leaves with distinct marginal teeth

Flowers in forked, terminal one-sided clusters ............ Virginia Stonecrop no. 264

Flowers not terminal: from among the leaves

Flower cluster shorter than the leaf-stalk

Clearweed no. 265

Flower cluster longer than the leaf-stalk, at least the upper ones...$\ldots \ldots \ldots \ldots \ldots \ldots \ldots$. False Nettle no. 266 

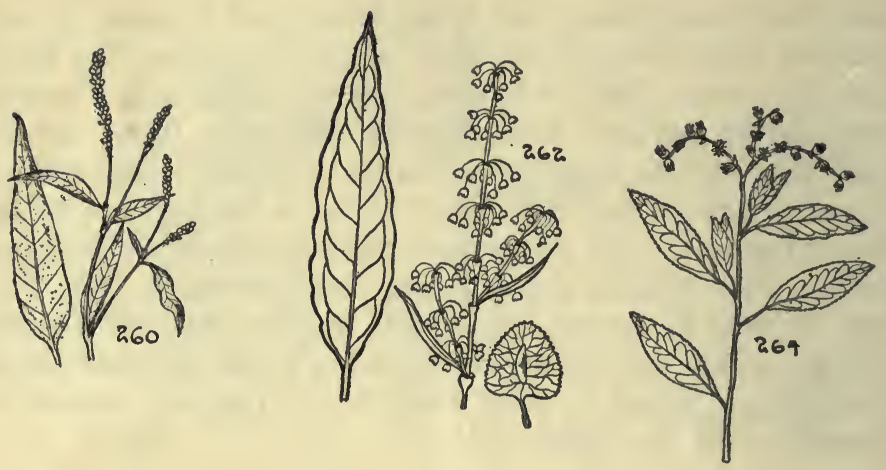

258. Water Carpet. Chrysosplenium americanum. (Saxifragaceae.) A low prostrate smooth herb with mostly opposite, nearly round leaves about $3 / 4$ in. in diameter, nearly stalkless, and obscurely wavy-margined. Flowers green, scarcely $1 / 10$ in. across, usually solitary, at the leaf-bases. Often growing in dense mats in cool wet shaded places. Nova Scotia to Ga., and westward. April. Fig. 258. (For other plants of this family see Nos. 497, 509, 5 IO, 5 I2 and 522.) 259. Lizard's-TaIl. Saururus cermus. (Saururaceae.) A swamp plant, but often in open wet meadows, $\mathrm{I}-3 \mathrm{ft}$. tall, not much branched. Leaves alternate, 3-6 in. long, 2-3 in. wide, deeply heart-shaped at the base, sharp-pointed at the tip, without teeth, stalked. Flowers greenish-white, in a slender finger-shaped cluster from among the leaves. R. I. to Florida and westward. July.

260. Mild Water-Pepper. Persicaria hydropiperoides. (Polygonum hydropiperoides.) (Polygonaceac.) A perennial herb of moist or wet places, $\mathrm{I}-3 \mathrm{ft}$. tall, with alternate narrow leaves $2-6$ in. long, pointed at both ends, very short-stalked, and finely hairy on the margins. At each leaf base there is a short fringed sheath. Flowers in slender, finger-shaped clusters, pinkish-purple. Petals none. New Brunswick to Florida and Mexico, and westward. July. Fig. 260. There are many related species, mostly weeds. (See Nos. 204, 205, 246, $247,26 \mathrm{I}-263,270,294$.) 


\section{6r. WATER DOCKS. RUMEX.}

Tall, coarse, herbs with often wavy margined leaves, but no marginal teeth. Flowers green in large, usually muchbranched clusters, and in these Water Docks, the individual flowers on slender drooping stalklets. Fruit dry, surrounded by a flat veiny wing. (Polygonaceae.) There are several plants of the same family, mostly weeds; see especially, Nos. 270, and 294.

Leaves wavy-margined, the lower ones I2-24 in. long; wings toothed. 262. Great Water Dock. Rumex Britannica. A stout dark green erect herb 3-6 ft. tall, often branched, the stem grooved. Leaves oblong, pointed at both ends, the lower ones twice as long as the upper ones, and long stalked. Flower cluster much branched, the ultimate clusters interrupted and on slender stalklets all arising at the same place. Canada to Penn. and westward. July. Fig. 262.

Leaves flat, not wavy-margined, the lower ones $2-12$ in. long; wings toothless.

263. Swamp Dock. Rumex verticillatus. Much like No. 262, but usually not so tall, and bright green. In swamps from Quebec and Ontario to Florida, and westward. June.

264. Virginia Stonecrop. Penthorum sedoides. (Penthoraceae.) A ditch or swamp perennial herb usually under $2 \mathrm{ft}$. high with alternate stalked leaves that have shallow, but regular teeth. Leaves 2-4 in. long, narrowed at both ends, about $3 / 4$ in. wide. Flowers in a forked, one-sided terminal cluster, greenish, either without petals or with very inconspicuous ones. Fruit flattened, with $5-6$ beaks. New Brunswick to Fla. and westward. August. Fig. 264.

265. Clearweed. Pilea pumila. (Urticaceae.) A rather weak herb of swamps or moist shaded places not over 18 in. tall, wilting almost as soon as picked. Leaves opposite, their stalks as long as the leaf blade, which is $1 / 2-4$ in. long, prominently 3 -veined, and with coarse teeth. Flowers greenish, inconspicuous, in small clusters at the base of the leaf stalks, and shorter than them. New Brunswick and western Ontario to 

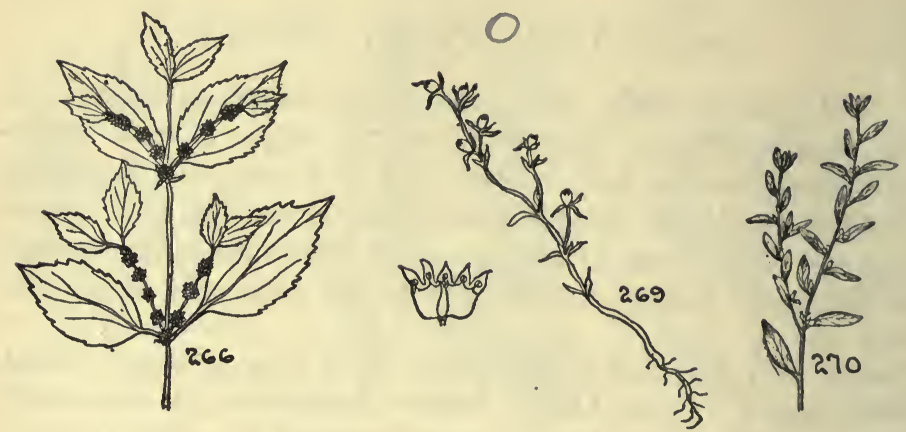

Florida, and westward. August. (For other plants of this family see also Nos. 266, 279 and 281.)

266. False NetTle. Boehmeria cylindrica. (Urticaceae.) Not unlike the preceding, but taller and coarser. Suggests also the Stinging Nettle (No. 279) but its foliage is stingless. Leaves usually all opposite, coarsely toothed, the blade $1 / 2-3$ in. long, pointed at the tip, blunt at the base. Leaf stalk shorter than the blade, and exceeded by the slender, apparently interrupted, greenish flower cluster. Moist shaded places. Quebec and Ontario to Florida, and westward. August. Fig. 266.

267. Plants of dry woods, roadsides, fields, or waste places; often mere weeds. (Nos. 268-303.)

There are 27 species in this group, growing in various situations but not usually in moist places. Nature, however, is somewhat fickle in its scattering of our wild flowers, and some of these may occasionally stray to moister sites, so look in Nos. 249-266, if you do not find your specimen here. They may be separated thus:

Stems or flower stalks erect

Plants prostrate, usually hugging the ground

Plant decidedly hairy; juice milky, leaves blotched...$\ldots \ldots \ldots$. 
Milk Purslane no. 268

Plants scarcely or not at all hairy; juice not milky, leaves plain green

Leaves opposite, almost scale-like; flower green ........... ......................... Parsley-piert no. 269 Leaves alternate, at least $1 / 3$ in. wide; flower pinkish .......

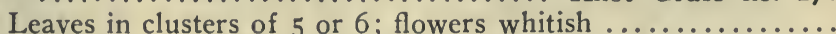
Knot Grass no. 270 Carpet-weed no. $27 \mathrm{I}$ 268. Milk Purslane. Chamaesyce maculata. (Euphorbia maculata.) (Euphorbiaceae.) A hairy spreading prostrate herb with milky juice and brownish or reddish blotches on its opposite, almost stalkless, leaves that are slightly oblique at the base. Leaves $1 / 6^{-I}$ in. long, and about half as wide, usually finely toothed. Flowers solitary at the leaf insertion, reddish white, without true petals. In dry, usually sandy soil. June-Sept. Ontario and New England to Florida and westward. See No. 252.

269. Parsley-Piert. Scleranthus annuus. (Corrigiolaceae.) Much branched, prostrate herb, not over 6 in. long, usually quite smooth, the stem slightly swollen at the leaf-bases. Leaves opposite, $1 / 6-3 / 4$ in. long, the tips sharp-pointed and often curved. Flowers less than $1 / 8$ in. in diameter, green, at the tips of tiny stalks arising between the leaves. Petals none. Fields and roadsides, or in waste places. A common weed introduced from Europe. April-Sept. Quebec and Ontario to Florida, and westward. Fig. 269.

27o. KNot grass. Polygonum aviculare. (Polygonaceae.) One of a group of weedy herbs, some erect, others hugging the ground, and some like $P$. aviculare merely weak or prostrate. Stems wiry and tough, usually striped or grooved. Leaves alternate, very short stalked, and pointed at both ends, $3 / 4-1 / 2$ in. long, about half as wide. On the stem near each leaf insertion there is a tiny silvery-shredded sheath. Petals none, but flowers pinkish-purple, in small clusters at the leaf bases, less than $1 / 6$ in. wide. Throughout North America as one of our commonest weeds, also nearly throughout Europe and Asia. June-October. Fig. 270. There are several other species, distinguished by rather technical char- 

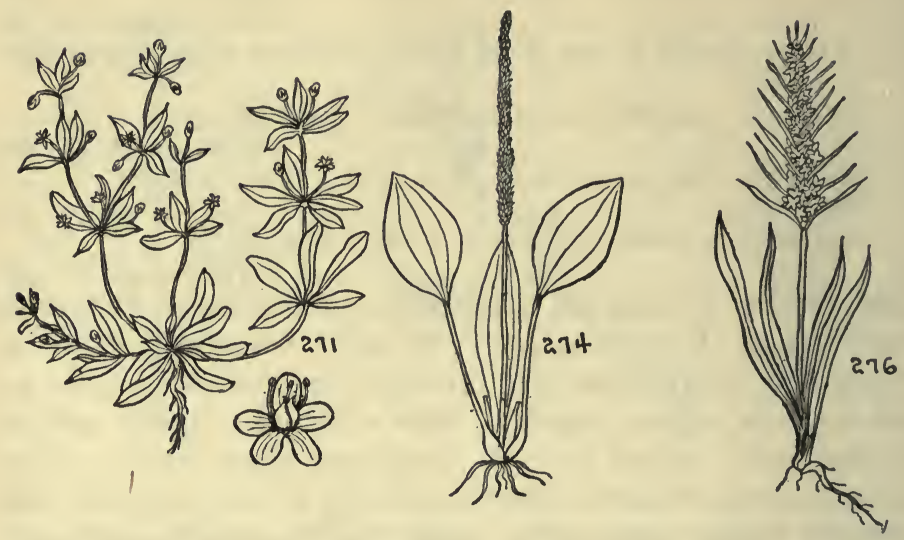

acters. One of them, Polygonum maritimum, is bluish-green and is a seaside plant from Mass. to Florida. See Nos. 204, 205, 246; 247, 260, 261, and 294.

27I. Carpet-weed. Mollugo verticillata. (Aizoaceac.) A smooth, weak, almost fleshy herb often making patches 18 in. across. Leaves 5 or 6 at each joint, broadest towards the tip, narrowed almost into a stalk at the base, $1 / 2-I$ in. long. Flowers whitish, less than $1 / 8$ in. across on slender stalks, almost as long as the leaves, or occasionally longer. Petals none. Common as a weed in waste places and cultivated ground from Canada to Mexico. May-Sept. Fig. 27I.

272. Stems or flower-stalks erect. (Nos. 273-303.)

Stem leaves obvious $\ldots \ldots \ldots \ldots \ldots \ldots \ldots \ldots \ldots \ldots \ldots$ no. 277 Leaves wholly basal .................. Plantains no. 273

273. PLANTAINS. PLANTAGO.

Stemless herbs with an erect flower cluster rising from a rosette of basal leaves. Leaves apparently parallel-veined, rather prominently ribbed in some species. Flowers incon- 
spicuous, greenish-brown, borne in slender elongated erect spikes. Petals present, but small, and partly hidden by the sepals and bracts in some species. Fruit a tiny dry, pointed pod. (Plantaginaceae.)

Leaves broad, obviously long-stalked .. Common Plantain no. 274

Leaves narrow, diminishing towards the base, not obviously long stalked

Flower cluster I-4 in. long, without the bracts of No. $276 \ldots$. .

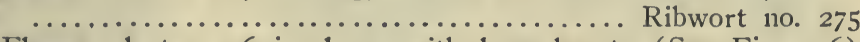

Flower cluster 2-6 in. long, with long bracts (See Fig. 276) Bracted Plantain no. 276

274. Common Plantain. Plantago major. A tough, smooth, coarse perennial with a rosette of basal leaves prominently 3-II ribbed. Leaf-stalk usually twice the length of the blade. Leaf-blade oval, $2-5$ in. long, pointed at both ends. Stalk of the flower cluster 6-18 in. tall, the slender spike about $1 / 4$ in. thick. A weed throughout North America. May-Sept. Fig. 274. There are one or two close relatives, one of which grows in salt marshes. It is similar to the preceding, but decidedly hairy, a little fleshy, and is known as Plantago halophila.

275. Ribwort. Plantago lanccolata. Flower cluster similar to No. 274, but a little shorter and thicker, without bracts. (See Fig. 276.) Leaves lance-shaped, 3-9 in. long, prominently $3-5$ ribbed, narrowed almost to a leaf-stalk towards the base. A common weed nearly everywhere, but a native of Europe. April-October.

276. Bracted Plantain. Plantago aristata. A dark green slightly woolly plant with long narrow leaves that are exceeded by the stalk of the flower cluster. Leaves scarcely $1 / 4$ in. wide, often 3 -ribbed, pointed at the tip, and narrowed at the base into a short leaf-stalk. Flower cluster rather dense, hairy, but not woolly, 2-6 in. long. Between each flower there arises a long narrow bract. Common as a weed in dry places from Maine to Georgia, and westward, where it is native on dry plains and prairics. May-October. Fig. 276. 

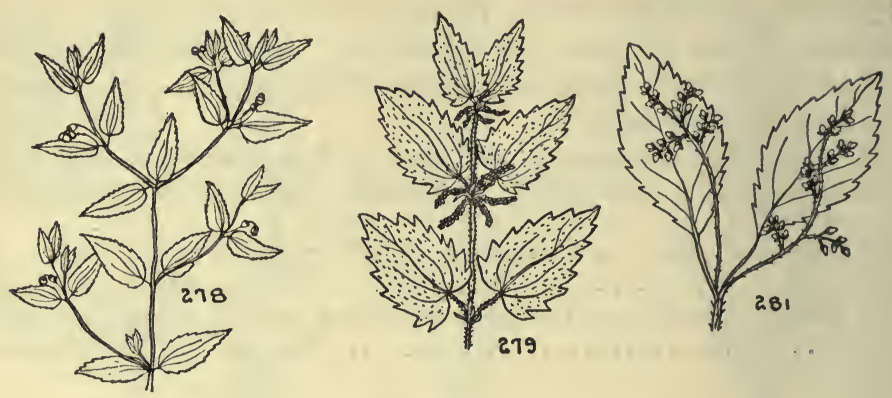

277. Stem leaves obvious. (Nos. 278-303.)

Leaves alternate $\ldots \ldots \ldots \ldots \ldots \ldots \ldots \ldots \ldots \ldots$ no. 280 Leaves opposite.

Leaves often red blotched, faintly toothed, short stalked ...... ......................... Spotted Spurge no. 278 Leaves green, deeply toothed, long stalked ................

........................ Stinging Nettle no. 279 278. Spotted Spurge. Chamaesyce Preslii. (Euphorbia Preslii.) (Euphorbiaceae.) An erect, often branched weed 8-20 in. tall, with opposite leaves and a milky juice. Leaves generally oblong, with a short slender stalk, often red blotched and red margined. Flowers reddish white, without petals, very small, in few-flowered clusters from the base of the leaf stalk. In fields and waste places. Ontario to Mass., south to Florida and westward. May-October. Fig. 278. (See also Nos. 252, 268, 419, 447, and 528-530.)

279. Stinging Nettle. Urtica dioica. (Urticaceae.) A stout herb $2-4 \mathrm{ft}$. tall densely clothed with stinging hairs. Leaves opposite, coarsely toothed, long-stalked, the blade $3-5$ in. long, and about half as wide, pointed at the tip, rounder or heart-shaped at the base. Flowers green, very small, in a much branched cluster near the leaf stalks. A weed of waste places from Newfoundland and Ontario to So. Carolina and westward. Native of Europe. August. Fig. 279. A related species, Urtica gracilis, also stinging, has narrower longpointed leaves, and is apparently a native plant with the same range as $U$. dioica. For other plants of this family see Nos. 265 and 28r, 
280. Leaves alternate. (Nos. 28I-303.)

Leaves without marginal teeth; wavy margined in some species

Leaves with distinct marginal teeth or lobes (Only shallow wavy teeth in No. 285)

Plant provided with stinging hairs .... Wood Nettle no. 28I Plants without stinging hairs 281. Wood NetTle. Urticastrum divaricatum. (Laportea canadensis.) (Urticaceac.) A stout plant of rich woods, with alternate long-stalked leaves provided with stinging hairs. Leaves thin, oval, 3-6 in. long, pointed both ends, sharply toothed. Flowers green, in a weak much-branched, rather sparsely flowered cluster that appears among the leaves and is much longer than the leaf-stalks. Petals none. Nova Scotia and Ontario, south to Florida and westward. Rare near the coast. July. Fig. 281. For other plants of this family see Nos. 265,266 and 279.

\section{GOOSEFOOT AND STRAWBERRY BLITE. CHENOPODIACEAE.}

Mostly weedy herbs of waste places with alternate usually coarse leaves that are often white-mealy, or hairy, and in No. 285, very strong smelling. Flowers without petals, inconspicuous, usually greenish-white, in branched clusters which may be terminal or arise among the leaves. There are at least twelve species in the region, separated by rather technical differences, of which the following are the most likely to be found.

Flower clusters from among the leaves, and usually shorter than them ........................... Goosefoot no. 283

Flower clusters usually terminal, or sometimes a few among the leaves.

Foliage mostly white-mealy; fruits dry ..... Goosefoot no. 284 Foliage green.

Foliage strong smelling; leaf margins very shallowly toothed, or merely wavy; fruits dry .......... Mexican Tea no. 285 Foliage odorless; leaf margins distinctly toothed; fruit suggesting a strawberry ........... Strawberry Blite no. 286 See also Nos. 250, 25I, 255, 256, and 312 . 

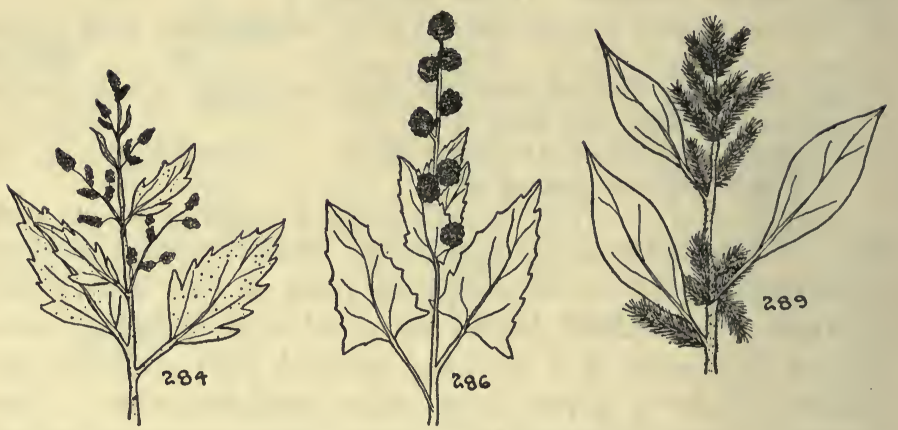

283. Goosefoot. Chenopodium murale. Annual weed, I-2 ft. tall, with stalked, broad-based leaves that are green both sides. Leaves $2-4$ in. long, nearly as wide, pointed at the tip, and coarsely toothed. Flowers in small clusters from among the leaves and shorter than them, rarely a few terminal. Common as a weed in waste places from Maine to Florida and westward. Native of Europe. June-Sept. A related species, Chenopodium hybridum, has fewer and coarser teeth, and a long pointed tip to its leaves, and is also a weed found from Quebec to Kentucky, and westward ; occasionally in woods and thickets.

284. Goosefoot or Pigweed. Chenopodium album. One of the commonest weeds throughout the civilized parts of North America. Stems usually branched, 2-8 ft. tall. Leaves alternate, 3 -veined, nearly always white-mealy on the under surface, lance-shaped, pointed at both ends, $\mathrm{I}^{\mathrm{I} / 2-4}$ in. long, stalked and irregularly but coarsely toothed. Flower cluster green, mostly terminal, but sometimes a few among the upper leaves. Native of Europe and Asia. June-Sept. Fig. 284. A similar plant, Chenopodium glaucum, also a nearly cosmopolitan European weed, has weak stems, and more regular marginal teeth to its leaves which are green above and whitemealy beneath.

285. Mexican Tea. Chenopodium ambrosioides. A coarse, usually smooth herb, $2-4 \mathrm{ft}$. tall, with strong smelling foliage. 


\section{A GUIDE TO THE WILD FLOWERS}

Leaves green, oblong or oblong-lance-shaped, I-5 in. long, the margins wavy and with a few shallow teeth. Flower clusters mostly among the upper leaves, and shorter than them, in apparently small interrupted heads. Fruits dry. In waste places from Ontario and Maine to Florida and westward. Native of tropical America. September. Another aromatic goosefoot, Chenopodium Botrys, has deeply toothed leaves and is covered with sticky hairs. Native of Europe and Asia, but occurring widely in North America as a weed in waste places.

286. Strawberry Blite. Blitum capitatum. (Chonopodium capitatum.) An annual herb 6-20 in. tall, with alternate green odorless leaves, the shape of an arrowhead. Leaves $1 \mathrm{r} / 2-2^{1} / 2$ in. long, coarsely but few-toothed. Flowers greenish-white in heads about $1 / 4$ in. in diameter, arranged in terminal clusters or from among the upper leaves. Fruits bright red and strawberry-like, about $1 / 2$ in. in diameter. In dry places. Nova Scotia to N. J. and westward. July. Fig. 286.

287. Leaves without marginal teeth; wavy margined in some species. (Nos. 288-303.)

Stems with a small sheath at each leaf insertion .............

Stems without such sheath.

Leaves not over $1 / 3$ in. wide, usually much less, and pointed ... Leaves over $1 / \ldots \ldots \ldots \ldots \ldots \ldots \ldots \ldots$. Pinweeds no. 291

\section{AMARANTH. AMARANTHACEAE.}

Coarse weedy annual herbs with alternate stalked leaves, often colored slightly in age, always without marginal teeth. Flowers greenish or purplish, without petals, in dense terminal pointed clusters, or else from among the upper leaves in much smaller clusters, or sometimes both ways. Fruit dry. There are sevcral species of which the following are most common. 
Leaves sharp-pointed, not under 3 in. long; flower cluster mostly terminal.

289. Green Amaranth. Amaranthus retroflexus. A stout, often rough hairy herb, 2-6 ft. tall with coarse long-stalked leaves 3-6 in. long, lance-shaped and pointed both ends. Flower clusters mostly dense terminal spikes, but a few among the upper leaves, often reddish tinged, but usually green. A common weed throughout North America. Native of tropical America. September. Fig. 289. A related species, A. hybridus, of the same range and origin has flower clusters about one half as large, usually less than $1 / 4$ in. in diameter. Leaves rounded at the tip, but with a minute prickle, not over $1 \frac{1}{2} \mathrm{in}$. long; flower-clusters mostly from among the leaves.

290. Tumble-ween. Amaranthus graecizans. A pale green, smooth, weedy plant with whitish branches, from 6-20 in. tall. Leaves narrowed at the base into a short stalk. Flower clusters usually not longer than the leaves, often as short as the leaf stalk, green. June-Sept. As the leaves drop in the fall, the stiff wiry stems are often uprooted and driven by the wind,-an admirable device to spread its seeds, hence its common name.

\section{9r. PINWEEDS. LECHEA. CIST ACEAE.}

Low perennial plants, growing nearly always in dry sand or in rocky places. Stems often a little woody at the base. Leaves of two kinds; one set borne on the stems and often as narrow as $1 / 10$ in., never more than $1 / 3$ in. wide and pointed at the tip; the other set, flat on the ground, appearing from the base of the stems late in the season, and often of very different shape and size from stem leaves. Flowers in minute clusters, the individual flower scarcely $1 / 10$ in. across, greenish or purplish, with 3 minute petals. Fruit a tiny capsule. There are eight or nine species in the region, all called Pinweeds. Few of them are distinguished as species by amateurs as they are puzzling. See also Nos. 334 and 480 . Two of the commonest are:

Leaves of the basal shoots oblong or oval, about half as wide as they are long; stem leaves about $1 / 4$ in. wide. 
292. Pinweed. Lechea minor. A stiff little herb, 6-20 in. high, more or less soft-hairy throughout. Stem leaves oval or oblong, almost stalkless, usually pointed both ends, and hairy on the margins. Basal leaves much more crowded, $1 / 4-1 / 2$ in. long, and half as wide. Flower clusters decidedly leafy, never showy. In dry thickets or open places from Ontario and Mass. to Florida, west to Michigan. August. A related plant growing on the sands of the seashore or near them is Lechea maritima. It has a larger flower cluster and narrower stem leaves, and is densely white-hairy.

Leaves of the basal shoots linear, about $1 / 6-1 / 10$ as wide as they are long; stem leaves about $1 / 10$ in. wide.

293. PinweEd. Lechea tenuifolia. A more slender wand-like plant 4-IO in. tall and covered with very short but stiff hairs. Stem leaves narrow, scarcely $1 / 10$ in. wide, pointed both ends, and rather sparsely arranged. Basal leaves similar, but about half the length, scarcely $1 / 3$ in. long. Flower clusters mostly at the ends of the branchlets, a little one-sided. August. Dry places from "New Hampshire to Florida, and westward. Fig. 293. A related species, Lechea intermedia, with broader basal leaves and sparser, more open flower clusters grows usually in rocky places from Nova Scotia to N. Y. and N. J. westward to Michigan and Wisconsin. See No. 334 for a related plant, the Frostweed.

\section{BUCKWHEAT FAMILY. POLYGONACEAE.}

A large family of plants, which are shrubs or trees in the tropics, but in our species are herbs (or vines, see Nos. 204,205 ). All those included below have alternate leaves without teeth and a tiny sheath which surrounds the stem, at the base of each leaf or leaf-stalk. These sheaths may be green or membranous and smooth or fringed at the top (see Fig. 298). Flowers small, in various kinds of clusters, with no petals but the sepals often colored. Fruit dry often surrouncled by a small wing. Other plants of this family are Nos. 204, 205, 246, 247, 260, 261, 262, 263, 270 and 961. The nine species below may be distinguished thus: 

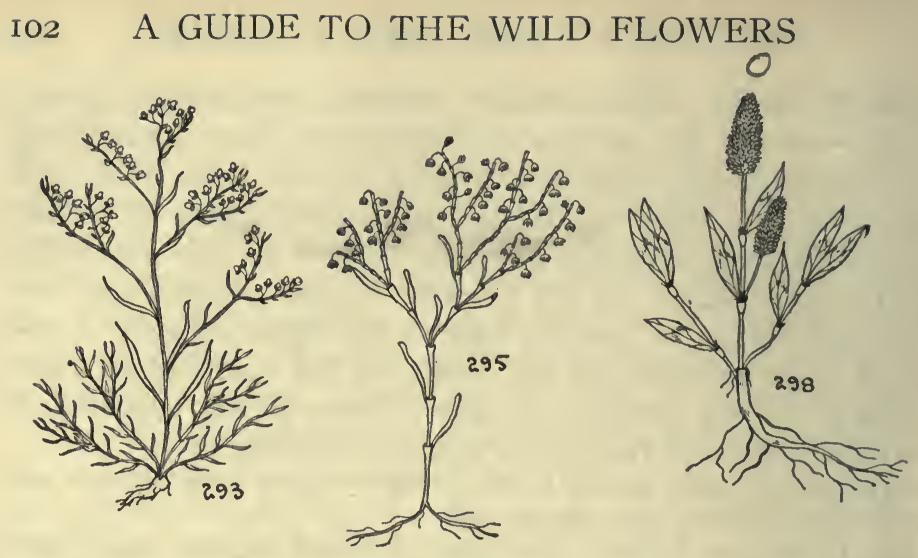

Leaves $1 / 4$ in. wide or less

Stems conspicuously jointed, leaves parallel-margined .......

....................... Coast Joint-weed no. 295

Stems not jointed, leaves broadest at the middle . ...........

Leaves more than $1 / 2$ in. wide, usually much more

Flower clusters rather close, finger-shaped

Flowers red or crimson ........... Prince's Feather no. 297

Flowers greenish, white or pink, not deep red ............

....................... Lady's Thumb no. 298

Flower clusters rather open, usually much branched

Leaves oval, plant 4-8 ft. tall ... Japanese Knotweed no. 299

Leaves arrowhead-shaped, plants less than $3 \mathrm{ft}$. tall

Flowers greenish-white; plants mostly less than I ft. tall ............................... Sield Sorrel no. 300 Flowers white; plants $\mathrm{I}-\mathrm{I} \mathrm{T} / 2 \mathrm{ft}$. tall ... Buckwheat no. $30 \mathrm{I}$ Leaves lance-oblong, the margins wavy and crisped

Flower cluster long, almost thread-like, unbranched ......... Dock no. 302

Virginia Knotweed no. 303 295. Coast Joint-ween. Polygonclla articulata. An annual wiry bluish-green herb, 6-Io in. tall with distinctly jointed stems, and generally suggesting the heather. Leaves narrow, scarcely $1 / 5$ in. wide, not over $I^{1} / 2$ long. Flower clusters open, few-flowered, pinkish, mostly at the ends of the branchlets. In sandy places, along and near the coast. Maine to Florida, and along the shores of the Great Lakes. August. Fig. 295.

296. Knotweed. Polygonum tcmuc. A slender weedy plant, 
6-12 in. tall, with a somewhat 4-angled stem, a little rough at the joints. Leaves broadest towards the middle, tapering at both ends, $1 / 3-I$ in. long, about a fourth as wide. Sheaths at the leaf base thread-like at the top. Flowers a few, in small clusters from among the leaves, green. In dry soil and often a weed, Ontario to Georgia and westward. August. Other Knotweeds are Nos. 270 and 299, and there are additional species distinguished by technical differences.

297. Prince's Feather. Persicaria orientalis. (Polygonum orientale.) A tall annual, 2-6 ft. high, with an erect, usually branched rough-hairy stem. Leaves alternate, oval or broadly oblong, more pointed at the tip than at the base, $3-8$ in. long, and about half as wide. Flowers red or crimson, in drooping, finger-shaped clusters. August. Often cultivated and frequently escaping to waste places throughout eastern North America. Native of India.

298. Lady's Thumb. Persicaria Persicaria. (Polygonum Persicaria.) A smooth or faintly hairy plant, 8-20 in. high, with conspicuously dotted leaves which are often blotched. Leaves lance-oblong, essentially stalkless, narrowed towards the tip and base, $2-5$ in. long, and about one third as wide. Flowers in finger-shaped erect clusters, pinkish. One of the commonest weeds throughout North America on waste or cultivated land. Native of Europe. June-October. Fig. 298. There are several relatives, distinguished by technical characters, besides Nos. 297 and 299. Other closely related plants are Nos. 260 and 961.

299. Japanese Knotweed. Pleuropterus Zuccarinii. (Polygonum cuspidatum.) An erect or arching, usually branched herb, 4-8 ft. tall, with a smooth or scurfy stem and alternate leaves distinctly marginally veined. Leaves broadly oval, short-stalked, 3-5 in. long, rather abruptly narrowed at the tip, and broad at the base. Flowers greenish-white in loose, open, much-branched usually terminal clusters. Cultivated, and sometimes escaping to fields and waste places. Native of Japan. July-October.

300. Field Sorrel. Rumcx Acctosclla. A smooth herb not over 12 in. high with arrowhead-shaped leaves, both basal and on the stem. Foliage bitter and used for greens by some. 

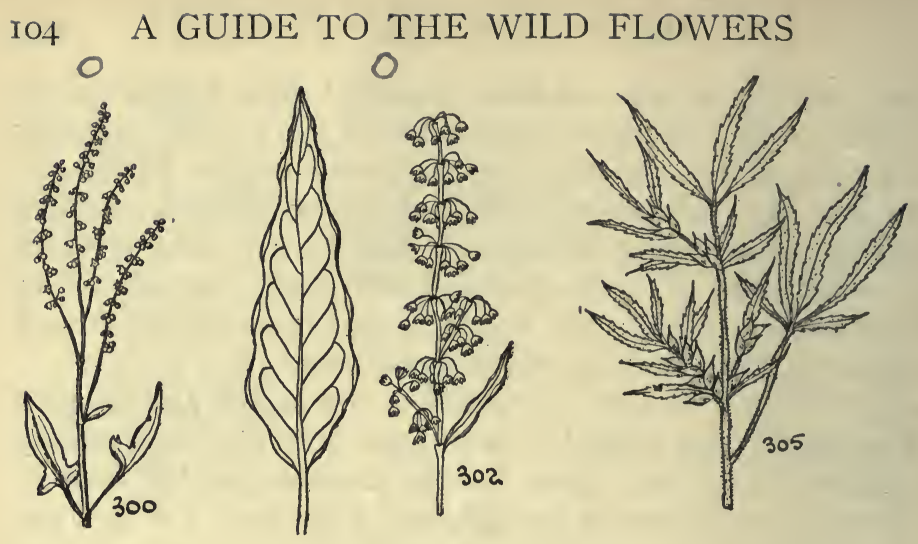

Leaves I-4 in. long, tapering to a point towards the tip, usually arrow shaped at the base, often reddish. Flowers small, in erect loose clusters, greenish-white. In dry "sour" fields nearly throughout North America, although a native of Europe. May-September. Fig. 300. There are several relatives, mostly difficult to identify, or very rare. Other species of Rumex in this book are Nos. 262, 263, and 302.

30r. Buckwheat. Fagopyrum Fagopyrum. (Fagopyrum esculentum.) A perfectly smooth herb from $\mathrm{I}-2 \mathrm{I} / 2 \mathrm{ft}$. high, often a little weak, but never prostrate. Leaves broadly arrowhead-shaped, but, unlike the preceding almost perfectly triangular in outline. Flowers white, in short rather compact clusters, but these not finger-shaped as in Nos. 297 or 298. Sometimes the flower clusters droop a little, especially in fruit. The triangular, winged fruit is the buckwheat of commerce. Occasional as a waif after cultivation, not usually persistent, but often locally common. Native of eastern Europe or adjacent regions of Asia. August.

302. Common Dock. Rumcx crispus. An erect somewhat slender perennial $\mathrm{I} / 2-3 \mathrm{ft}$. high, with a grooved stem. Leaves oblong, or lance-oblong, the margins wavy and somewhat crisped, but without real teeth. Flowers green in a muchbranched cluster, the final aggregations of flowers on small drooping stalks, all arising at the same place. An Old World plant now spreading throughout North America, and one of 
our commonest weeds in fields and waste places. July. Fig. 302. See also Nos. 262, 263, and 300.

303. Virginia Knotweed. Tovara virginiana. (Polygonum virginianum.) An erect or slightly arching perennial, I-3 ft. high, with large oval leaves more abruptly pointed at the tip than towards the base. Leaves short-stalked, 2-6 in. long, slightly hairy on the margins, but without teeth. Sheaths at the base of the leaf-stalk tightly stem-clasping, fringed with bristles. Flowers greenish-rose, scarcely $1 / 10$ in. across, scattered rather sparsely along an almost thread-like stalk from 4-12 in. long. In woods, usually in rather rich soil. Nova Scotia to Florida and westward. September.

304. Stem leaves either actually compound or much divided. (Nos. 305-3II.)

Leaves divided (in no. 305 deeply so) but not compound

Leaves divided to the base, appearing as with narrow separate leaflets .......................... Hemp no. 305

Leaves divided to about the middle, the lobes broad ..........

Golden Seal no. 306

Leaves truly compound, the ultimate divisions of separate leaflets Leaves once compound, the leaflets sharply and regularly toothed; flowers white $\ldots \ldots \ldots \ldots \ldots \ldots$. Burnet no. 307

Lcaflets thrice compound, the leaflets toothed mostly towards the tip and bluntly so; flowers greenish Meadow Rue no. 308 305. Hemp. Cannabis sativa. (Cannabinaceae.) A coarse hairy annual herb 2-8 ft. tall with tough fibrous bark and large leaves divided finger-fashion practically to the base. Divisions of the leaf long, narrow, and sharply toothed, $3-6$ in. long. Flowers in clusters from among the leaves, greenish and inconspicuous. Mostly in waste places from Canada to No. Carolina and westward. The Hasheesh of the Orient from where it has been introduced. August. Fig. 305. See also No. 198 .

306. Golden Seat. Hydrastis canadensis. (Ramunculaceae.) A somewhat rare plant of rich woodlands, not over I ft. high, arising from a thick yellow rootstock. There is one large basal leaf, divided about to the middle, into 5-9 toothed 

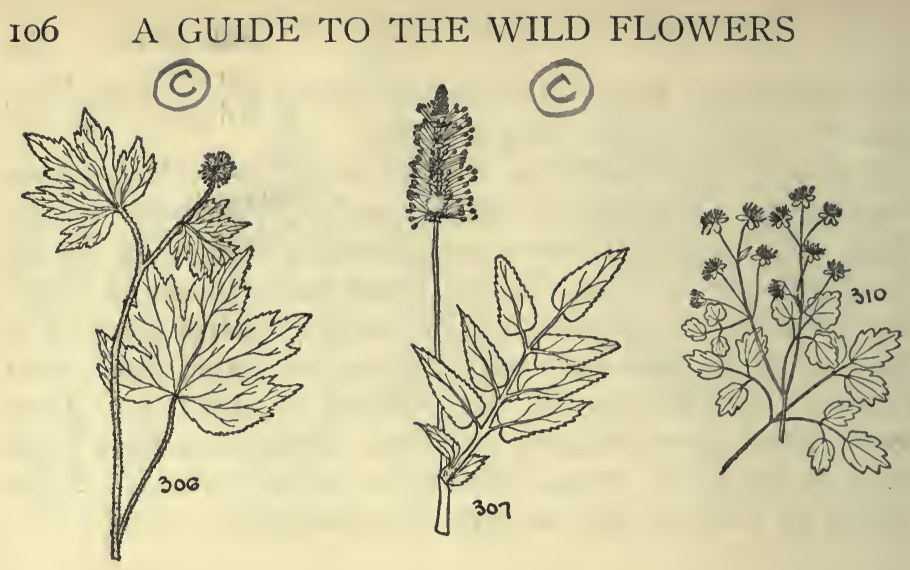

broad lobes. Just below the flower are 2 stem leaves, much smaller and usually fewer lobed. Flower solitary, without petals, its greenish-white sepals soon falling. Much collected for its valuable medicinal rootstock. April. Ontario to Virginia and westward. Rare. Fig. 306. See also No. 349.

307. Burnet. Sanguisorba canadensis. (Rosaceae.) A smooth herb of swamps or meadows, with often branching stems 2-6 ft. high. Leaves compound, the stalked regularly toothed leaflets in 3-7 opposite pairs with an odd one at the tip. Flowers white, in dense terminal spikes, $\mathrm{I}-5$ in. long, without petals, the color derived from the stamens. Newfoundland to Georgia, west to Michigan. August. Fig. 307. See No. 359 .

\section{MEADOW RUE. THALICTRUM.}

Tall graceful herbs, often in moist places, with branching stems, and thrice compound leaves, the ultimate leaflets of which are few toothed towards the tip, the teeth blunt or rounded. Flowers in much branched clusters, without petals, and the 4-5 petal-like sepals soon falling. Stamens numerous, and it is these that give the flowers their greenish-white or greenish-purple color. Fruit dry, with a pointed tip. (Ranunculaceae.) See No. 349. There are eight or nine species of which the following may be distinguished here; 
Leaflets somewhat sticky and waxy beneath..Meadow Rue no. 309 Leaflets not so

Flowers greenish; woods plant, I-2 ft. high

Early Meadow Rue no. 310

Flowers greenish-purple; meadow plant, 3-1o ft. high ........

309. MEADOW RuE. Thalictrum revolutum. A tall stout herb, 3-8 ft. high, the stem branched and often purplish. Leaflets dark green on the upper surface, waxy and resinous and paler on the lower, mostly with three shallow blunt teeth towards the tip, or even shallowly 3 -lobed. Flowers greenishyellow, numerous in a much branched cluster. Mostly in meadows and along stream banks. Ontario and Mass. to So. Carolina, and westward. June.

310. Early Meadow Rue. Thalictrum dioicum. A woods plant, scarcely over $2 \mathrm{ft}$. tall, with delicate leaves, the ultimate leaflets thin, roundish, with $5-7$ blunt teeth towards the tip, often slightly heart-shaped at the base. Flowers greenish, in a small but much branched cluster. May. Maine to Alabama, and westward. Fig. 3IO.

3II. Fall Meadow Rue. Thalictrum polygamum. Tall branching herb $3^{-10} \mathrm{ft}$. high, the foliage neither waxy nor resinous. Leaflets fairly thick, a little paler beneath than above, with three blunt teeth or lobes at the tip. Flowers greenish-white, or greenish-purple, very numerous in a large much branched cluster, which may be from 8-I4 in. long and half as wide. Open wet places, Newfoundland to Florida, and westward to Ohio. June. Fig. 3I I.

\section{GLASSWORT. SALICORNIA.}

Fleshy herbs of the salt marshes, with opposite scaly jointed branchlets like miniature clubs. Leaves reduced to tiny overlapping scales. Between the upper scales of the branchlets the tiny flowers appear. They are without petals, and with inconspicuous tiny sepals. (Chenopodiaceae.) Of the three species the best known is:

Glasswort. Salicornia europaca. A leafless much-branched herl, 6-I 5 in. tall, the branchlets jointed, the joints usually 

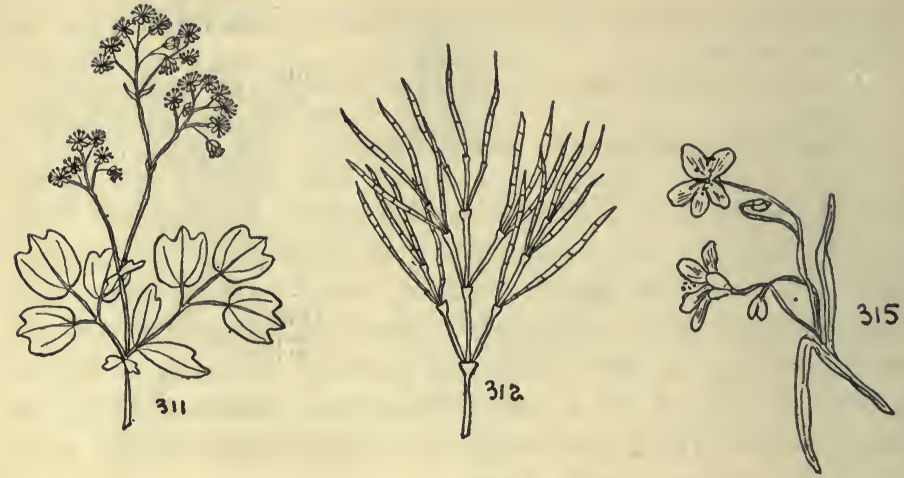

about 3 times as long as thick. The whole plant, as well as its relatives, a bright red in the fall, often coloring large stretches of the salt meadows,- -hence its other name of Samphire. In salt marshes from Canada to Georgia, but also about salt springs, and occasionally in the run-off of pickle factories in the interior. September. Fig. 3I2. Also in Europe and Asia. See No. 282. 
Plants with Obvious Petals, or if These are Lacking, the Petal-like Sepals Colored and Showy. Petals Separate, not United to Form a Tube, and the Flowers Symmetrical, Never Pealike, or Violet-like, or Spurred. Flowers not Arranged as in the Carrot Family, See No. 526. (Nos. 314-525.)

There are about 170 different kinds of wild flowers in this group, often of distant relationship. They all agree in having symmetrical flowers, of essentially separate petals which are either conspicuous and showy, or are replaced by sepals that give color to the flower. There is no sort of a tubular or cupshaped corolla, nor are any of them irregular, as are the peas, violets, milkworts, or the spurred flowers of the columbine. All these irregular flowered herbs will be found under No. 556 .

The main divisions of this group are as follows:

Leaves insect catching, either like a bent pitcher, or if not so, covered with glistening hairs

................... Pitcher Plant and Sundew no. 488

Leaves, if present, not insect catching, usually normal

Leaves wanting, the green leaf-like joints swollen and prickly

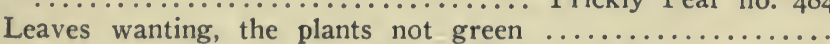
................. Indian Pipe and Pine Sap no. 485

Leaves present, but reduced to small opposite scales, the plant thus appearing leafless ...... Orange-Grass no. 483

Leaves present, not reduced to scales

Leaves exclusively basal, or with only I or 2 stem leaves, rarely more (See Nos. 524 and 525 ) ........ no. 492 Some or all the leaves on the stem at flowering time, basal leaves sometimes present

Leaves opposite or with more than 2 at each joint .....

Leaves alternate $\ldots \ldots \ldots \ldots \ldots \ldots \ldots \ldots \ldots$ no. ${ }^{110}$

314. Leaves alternate. (Nos. 315-409.)

There are several exceptions to be noted: Wall Pepper, No. $33^{2}$ has tiny crowded leaves; Wild Stonecrop, No. 317, 
has some leaves in 3's; Blue Cohosh, No. 344, has 2 compound leaves; Spring Beauty, No. 315, has opposite, alternate and basal leaves.

About 80 alternate leaved herbs are to be considered here, of which the major differences can be set down thus:

Petals or petal-like sepals 4 , or less than $4 \ldots \ldots \ldots \ldots$ no. 377 Petals or petal-like sepals 5 , or more than 5

Leaves compound, or deeply divided, or cut (except in a buttercup No. 351) ........................... no. 336

Leaves not compound, or deeply divided, or cut (Exceptions in Modesty, no. 324, and Musk-mallow, no. 326)

Flowers yellow ......................... no. 328 Flowers of other colors

Stamens united to form a tube (See Fig. 323)

Stamens separated

Plants $4-8 \mathrm{ft}$. high .............. Pokeweed no. 320

Plants $3-15$ in. high.

Flowers blue ................... Flax no. 319

Flowers not blue

Sepals 5, united; petals $5 \ldots .$. . Stonecrop no. 316 Sepals 2, free; petals 5 ..... Spring Beauty no. 3I5

\section{SPRING BEAUTY. CLAYTONIA.}

Low perennial smooth herbs with alternate, or opposite, or basal leaves, stalked or stalkless. Flowers in a terminal sparse cluster, consisting of usually not more than 3-7 flowers. Sepals 2, petals 5, whitish or pinkish, and veined. Fruit an oval or round capsule. (Portulacaceae.) See No. 33I. The commonest species is

Spring Beauty. Claytonia virginica. Not over 8 in. tall, usually weak, and quickly wilting when picked. Basal leaf (often missing) from a deep tuberous root, three times as long as the usually opposite stem leaves which are $\mathrm{I}-4 \mathrm{in}$. long; all strap-shaped and without teeth. Flower about $3 / 4$ in. wide, with pinkish veins; slightly notched. Moist woods or swamps. Nova Scotia to Georgia, and westward. April. Fig. 315. A related species with broader leaves, $C$. caroliniana, is found mostly in the mountains from Nova Scotia to So. Carolina and westward. 

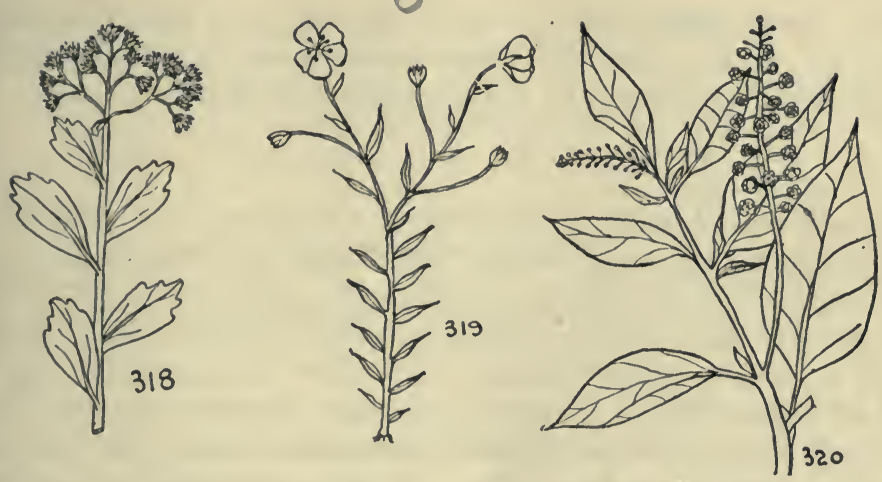

316. STONECROP. SEDUM.

Fleshy or succulent herbs with alternate leaves (in 3 's in No. 3I7) and simple or branching stems. Leaves mostly thick and fleshy, with or without teeth, in some species appearing crowded (see No. 332). Flowers in terminal, sometimes Isided, clusters. Sepals 5, united. Petals 5, separated, often pointed. Fruit a dry pod. (Crassulaccae.) Nine species are known from the area. Besides the Wall-pepper (No. 332), treated elsewhere, the following are distinguished thus:

Leaves in 3 's or alternate; flowers white.

317. Wild Stonecrop. Sedum ternatum. A low almost prostrate plant with erect or ascending flowering branches $3-8$ in. high. Lower leaves mostly in 3 's, the upper ones alternate, all stalkless, about $3 / 4$ in. long, without teeth. Flowers pink, in a I-sided terminal, often 3 -branched cluster. In rocky woods. Conn. and N. J. to Georgia, and westward. May. Leaves alternate; flowers pink.

318. American Orpine. Sedum telcphioides. A slender fleshy plant with bluish or purplish foliage scarcely 9 in. tall. Leaves alternate, oval, usually coarsely toothed toward the tip, narrowed toward the base, almost stalkless, about $\mathrm{I} 1 / 2 \mathrm{in}$. long and half as broad. Flowers in a terminal, almost flat-topped cluster, not one-sided, pink. In dry rocky woods. Southern Penn. and Maryland to western N. Y. and Indiana. August. Fig. 318. A related European species, S. triphyllum, 
(S. purpureum) with purplish flowers, and leaves toothed nearly to the base, is found in fields and roadsides from Quebec and Ontario to Maryland and Michigan.

319. Flax. Linum usitatissimum. (Linaceae.) A wand-like erect but weak herb, slightly branching, not over 18 in. tall. Leaves alternate, pointed at both ends, stalkless, about $3 / 4$ in. long and half as wide, often 3 -veined. Flowers blue, about $3 / 4$ in. across, usually solitary on a short stalk near the upper leaf bases. Sepals and petals 5 each, separate. August. In waste places as an escape from cultivation. Native of Europe and the source of linen. Fig. 319. Its yellow-flowered American relative is treated at No. 335 .

320. Pokeweed. Phytolacca americana. (Phytolacca decandra.) (Phytolaccaceae.) A coarse stout herb 4-8 ft. high with an erect branching stem, and a poisonous root. Leaves 8-12 in. long, about $1 / 3$ as wide, gradually pointed both ends, stalked, and without teeth. Flowers in terminal ample racemes. Petals none, but the 5 sepals white and petal-like. Fruit a fleshy berry, about $1 / 2$ in. in diameter, its copious juice staining dark purple. June-Sept. From Maine and Ontario to Florida, mostly in waste places as a weed, but appearing wild among the sea beach dunes. Fig. 320 .

\section{MALLOWS. $M A L V A C E A E$.}

Herbs or shrubs (often trees in the tropics) with mostly alternate leaves, the principal veins of which all arise at the base of the blade. Flowers solitary, or in small clusters, often very showy, as in the cultivated mallows. Sepals 5 , often with another series of bracts below them. Petals 5, separate above, but all more or less united towards the base. Stamens numerous, all joined into a central tube from which the pistil protrudes, or in which it may be partly hidden. Fruit a several-celled capsule, see fig. 323. There are many species and genera. The following are separated thus:

Plants $2 \frac{\mathrm{T}}{2}-\mathrm{T}$ ft. tall.

Flowers $\mathrm{I}-\mathrm{I} 1 / 2$ in. broad .............. Marsh-mallow no. 322 
Flowers $4-7$ in. broad .............. Rose-mallow no. 323 Plants mostly less than $2 \mathrm{ft}$. tall

Plants prostrate or nearly so

Flowers purple-yellow; leaves divided ...... Modesty no. 324 Flowers pale blue; leaves toothed but not divided ...........

Plants erect

Cheeses no. 325

Flowers pink or white; leaves much cut

Musk Mallow no. 326

Flowers reddish-purple; leaves merely lobed

See also no. 330 .

322. Marsh-mallow. Althaca officinalis. An erect perennial $2 \mathrm{I} / 2-4 \mathrm{ft}$. high, covered on all its parts with a dense velvety hairiness. Leaves somewhat 3-lobed, the margins, finely toothed. Flowers often solitary among the leaves, or in fewflowered terminal clusters. Petals separate almost to the base, more or less spreading, the flower $\mathrm{I}-\mathrm{I} 1 / 2$ in broad, pink. Below the calyx is a series of 6-9 linear bracts. August. In salt marshes and saline situations. Mass., Conn., and N. Y., also in Penn. and Michigan. Much less common than

323. Rose-mallow. Hibiscus Moscheutos. A stout salt marsh herb, sometimes in fresh water meadows, 4-7 ft. tall, with an almost woody stem. Leaves broadly oval, pointed at the tip and rounded at the base, green above and pale and velvety beneath, 3-7 in. long and stalked. Flowers 4-7 in. in diameter, white, or pink, or white with a crimson eye. August. Mass. to Florida and Louisiana, and in saline situations in the interior. Fig. 323. A related species, $H$ militaris, with pink, darker eyed, flowers, and 3 -lobed leaves is found along fresh water streams from Penn. to Florida, and westward. 324. Modesty. Hibiscus Trionum. A nearly prostrate hairy plant with stalked 3 -lobed, or even more divided leaves, the segments toothed. Flowers $\mathrm{I}-2 \mathrm{I} / 2$ in. wide, purplish-yellow, solitary at each of the upper leaves, fading in a few hours. Calyx somewhat inflated, prominently veined and hairy, longer than the linear bracts below it. August. In waste places. Nova Scotia to Florida, and westward. Native of southern Europe.

325. Cheeses. Malva rotundifolia. A prostrate plant, very common in waste places and fields, with long-stalked round- 

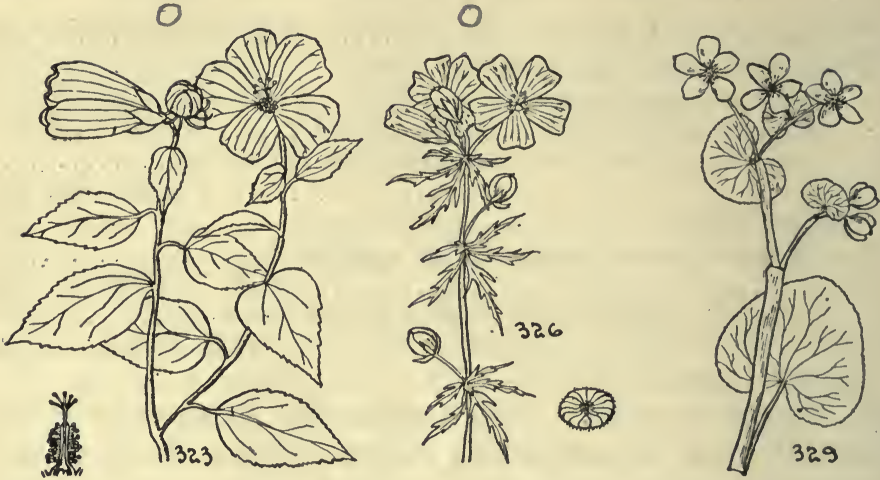

ish leaves, deeply heart-shaped at the base. Leaves $\mathrm{I}-3$ in. wide, about $1 / 3-1 / 4$ as wide as the length of the leaf-stalk, wavy-margined, and finely toothed. Flowers clustered among the leaves, their stalks $1 / 4$ the leaf-stalk, the petals pale blue, about $1 / 2$ in. wide, distinctly notched. Fruit suggesting a miniature flat cheese like that in Fig. 326. May-October. A European weed naturalized throughout North America. 326. Musk Mallow. Malva moschata. An erect herb, I-I I 12 $\mathrm{ft}$. high wth finely divided stem leaves, the segments cut and toothed. Basal leaves round. Flowers in terminal clusters, white or pink, about $\mathrm{I} / 2$ in. wide, the petals notched. Fruit about $3 / 4$ in. wide. August. In waste places or often along streams. Nova Scotia and Ontario to Virginia, and westward. Native of Europe. Fig. 326. Not as common as No. 325. 327. High Mallow. Malva sylvestris. An erect, branched, hairy herb, IO-18 in. high, with stalked leaves, finely toothed and with 5-9 shallow angular lobes. Flowers much like No. 326 , but reddish-purple and the petals rough and veiny on the back. August. In waste places or roadsides almost throughout North America, but not very common. Native of Europe.

328. Flowers yellow.

Petals none, sepals 5 ; a swamp or water plant ..............

Marsh Marigold no. 329 
Petals and sepals both present; not swamp or water plants.

Plant 3-5 ft. high; leaves $4-10$ in. wide

Plants not over $\mathrm{I}^{1 / 2} \mathrm{ft}$. high

Plants prostrate hugging the ground

Leaves clustered at the ends of the branches

........................... Pussley no. 33r

Leaves crowded along the sides of the branches ..........

Plants not prostrate; erect or sprawling

Wall-pepper no. 332

Leaves thistle-like, spiny ......... Prickly Poppy no. 333

Leaves wholly without teeth or spines

Flowers $3 / 4-1$ in. across ........... Frostweed no. 334

Flowers less than $1 / 2$ in. wide .... Yellow Flax no. 335 329. Marsh Marigold. Caltha palustris. (Ranunculaceae.) A stout, smooth, hollow-stemmed sprawling herb I-2 ft. long, with round deeply heart-shaped leaves, and yellow buttercup like flowers. Leaves stout-stalked, $2-7$ in. wide, bright green, the margins finely toothed or toothless. Petals none. Sepals 5, petal-like, and yellow. In swamps or open water. Newfoundland to So. Carolina, and westward. May. Fig. 329. See No. 349

330. Indian Mallow. Abutilon Abutilon. (A. Theophrasti.) (Malvaccac.) A coarse erect herb, $3-5 \mathrm{ft}$. tall with a branched hairy stem and large stalked velvety leaves, 4-IO in. wide. Leaves broadly oval, abruptly pointed at the tip and deeply heart-shaped at the base, practically without teeth. Flowers solitary at leaf insertions, yellow, about $3 / 4$ in. across, without a row of bracts beneath the calyx. September. Throughout North America as a weed. Native of Asia. For related plants and a description of the Mallow Family see Nos. 32 I- -327 .

33i. Pussley. Purslane. Portulaca oleracea. (Portulacaccac.) A prostrate fleshy weed, usually much branched, and hugging the ground. Leaves, alternate, but clustered towards the end of naked branchlets, without teeth, wedge-shaped, $1 / 4-3 / 4$ in. long, rounded at the tip. Flowers solitary, nestled in the terminal leaf-cluster, yellow, scarcely $\mathrm{r} / \mathrm{4}$ in. across, opening only on sunny mornings. Petals 5 , flat or slightly notched at the tip. August. Cosmopolitan in waste places, especially in cultivated land. Apparently native. Fig. 33I. See No. 315 . 

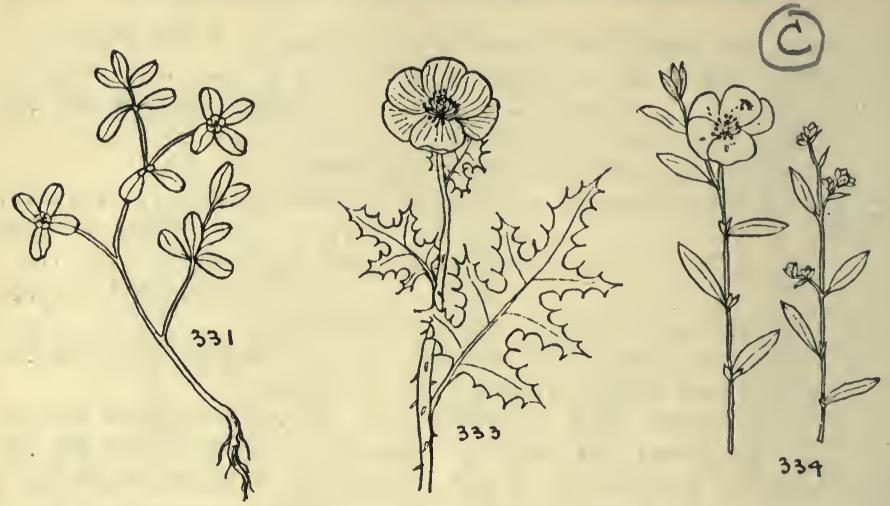

332. Wall-pepper. Sedum acre. (Crassulaceae.) A low prostrate smooth perennial growing in dense mats, from which the flowering branches rise $I-2$ in. high. Leaves scarcely $1 / 8$ in. long, densely crowded along the sides of the stems and surrounding them. Flowers in small clusters at the top of the flowering branches, yellow, about $1 / 3$ in. across. In rocky places and in fields, mostly as an escape from cultivation. Nova Scotia to Ontario and Virginia. July. Related plants, but with a different aspect are Nos. 3I7 and 318.

333. Prickly Poppy. Argemone mexicana. (Papaveraceae.) A usually spiny herb IO-I8 in. high with thistle-like foliage, and yellow juice. Leaves clasping the stem by the narrowed base, 3-8 in. long, almost a third as wide, rather deeply cut, and the margins spiny, bluish-green and white dotted. Flowers solitary, almost stalkless, I-2 in. across, pale yellow. Fruit a prickly pod about I in. long. August. Waste places, often on shingle beaches. Mass. to Florida. Native of tropical America. Fig. 333. See Nos. 404 and 500.

334. Frostweed. Crocanthemum canadense. (Helianthemum canadense.) (Cistaceae.) Erect or sprawling herb, almost woody at the base, with alternate toothless leaves, and yellow usually solitary flowers. Leaves essentially stalkless, narrowed both ends, $1 / 2-1 / 4$ in. long, and a third as wide, rough and dark green above, paler beneath. Flowers of two kinds: some 
small and without petals; others larger $3 / 4-\mathrm{I}$ in. wide with spreading yellow very fragile, broadly wedge-shaped petals. June. In dry places, especially in sandy fields. Maine and Ontario to No. Carolina, and westward. Fig. 334. There are several other species, all a good deal alike. The pinweeds are fairly close relatives. See Nos. 29I-293, 48I, and 482.

\section{YELLOW FLAX. CATHARTOLINUM.}

Slender herbs, usually under 18 in. tall, simple and wandlike, or a little branched. Leaves alternate, essentially stalkless and toothless, but sometimes minutely hairy on the margins. Sepals 5, some or all of them minutely toothed. Petals 5, yellow. Fruit a tiny dry pod. (Linaceac.)

See No. 3I9 for the common Blue Flax, a close relative.

Of the eight species of yellow flax the following is typical. All are much alike and difficult to separate without technical distinctions.

Yellow Flax. Cathartolinum virginianum. (Linum virginianum.) A slender branched perennial from 8-18 in. tall. Leaves thin, with a single vein (some related species have 3 ), $1 / 2-1$ in. long, pointed both ends. Flowers usually solitary, from the leaf-insertions, on very slender stalks, not over $1 / 3$ in. wide, pale yellow. Pod round, not over $1 / 8$ in. thick. In dry open places, or in woods. Maine and Ontario to Georgia. Some relatives extend far westward. July. Fig. 335 .

336. Leaves compound, or deeply divided or cut, except in the water spearwort, No. 351. (Nos. 337-376.)

Flowers yellow ........................... no. 348

Flowers neither yellow nor white $\ldots \ldots \ldots \ldots \ldots \ldots \ldots \ldots$ no. 343

Flowers white (rarely pinkish-white)

Leaflets only $3 \ldots \ldots \ldots \ldots \ldots \ldots$. Indian Physic no. 337 Leaflets more than 3 , often many more.

Sepals petal-like, separate, the leaves thrice compound

Plant I-2 ft. tall; fruit a berry ...... Baneberry no. 338 


\section{II8 A GUIDE TO THE WILD FLOWERS}
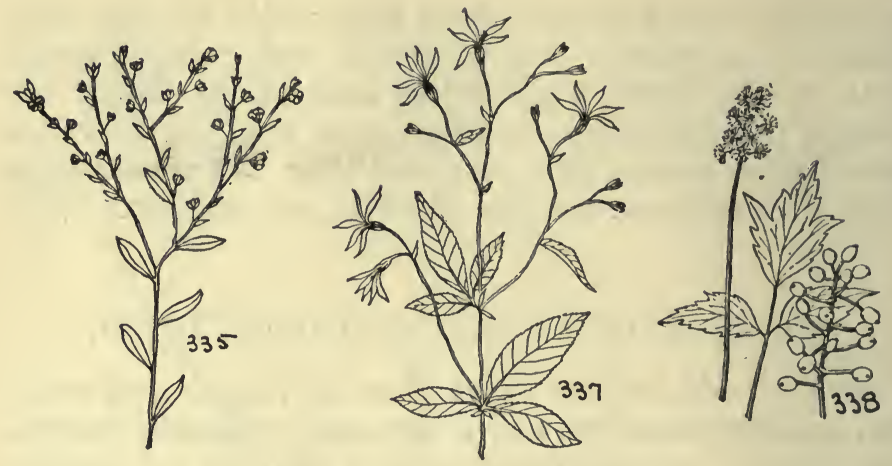

Plant 3-8 ft. tall; fruit a dry pod ..... Snakeroot no. 339 Sepals not petal-like, but green and united; petals 5, white Flower cluster much branched, its ultimate divisions slender and finger-shaped ............ Goat's-beard no. 340 Flower clusters little branched and few flowered, never finger-shaped

Leaflets of about equal size .... Tall Cinquefoil no. 34I Leaflets of conspicuously unequal size, the terminal ones

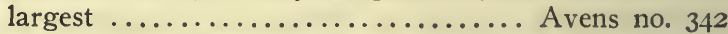

337. Indian Physic. Porteranthus trifoliatus. (Gillenia trifoliata.) (Rosaceae.) An erect branching perennial 2-4 ft. high. Leaves compound, of 3 leaflets which are wedge-shaped at the base, and taper to a point at the tip, sharply toothed and stalkless. Flowers white, the five strap-shaped petals rather limp and of slightly unequal length. Fruit a collection of 5 small beaked pods. In rich woods. Ontario and N. Y. to Georgia, and westward. Fig. 337. See No. 359.

338. Baneberry. Actaea alba. (Ramunculaccae.) A generally smooth branching perennial, not over $2 \mathrm{ft}$. tall, with thrice compound leaves, the ultimate leaflets toothed, short-stalked, and sharp pointed. Flowers small in terminal racemes, I-3 in. long, white. Petals small, inconspicuous and soon falling. Petal-like sepals separate. Stamens very numerous, white, giving most of the color to the flower. Fruit a white berry on a stout stalk. May. In rich woods. Nova Scotia and Newfoundland to Georgia and westward. Fig. 338. A related species, A. rubra, has red berries on slender stalks but is 

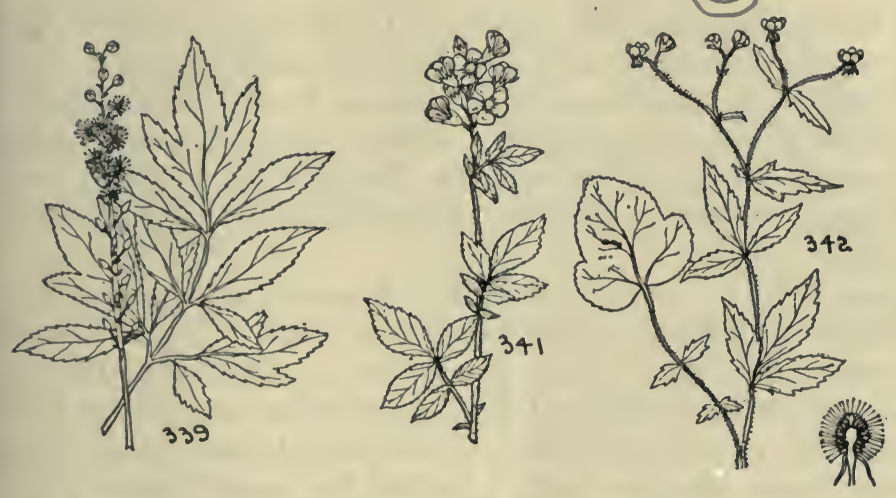

otherwise very similar. It grows in rich woods, mostly in the mountains from Nova Scotia to Penn., and westward. See No. 349.

339. Snakeroot. Cimicifuga racemosa. (Ranunculaceae.) A tall branching woodland plant often $6 \mathrm{ft}$. high. Leaves thrice compound, the ultimate leaflets toothed or cut, short stalked, and numerous. Flowers in a large much-branched cluster, its ultimate divisions long slender racemes, often $\mathrm{I} 2 \mathrm{in.long.}$ Stamens very numerous, giving most of the color to the plant. Petals inconspicuous, and soon falling. Fruit a dry pod. July. Maine and Ontario to Georgia, and westward. Fig. 339. See No. 349.

340. Goat's-beard. Aruncus Aruncus. (A. sylvester.) (Rosaccac.) A somewhat branched erect perennial, 3-7 ft. tall, with compound leaves. Leaflets usually not over I $3^{-17}$ in all, toothed and practically stalkless, except the terminal one. Flowers white, in a large branched cluster, its ultimate divisions finger-like. Sepals united at the base, green. Petals 5, rounded. Fruit a dry pointed pod. June. In rich woods. Penn. to Georgia, and westward. Also in Europe and Asia. Much cultivated, and often escaping out of its wild range. See No. 359.

34r. Tall Cinquefoil. Drymocallis agrimonioides. (Potentilla arguta.) (Rosaccae.) A sticky, hairy perennial, I-3 ft. tall. 
Leaves compound, the leaflets 7-II, of about uniform size, toothed, essentially stalkless. Flowers numerous in a close terminal cluster among the topmost leaves. Sepals green, united at the base. Petals 5, white, rounded, and broadest towards the top. Stamens many. June. In rocky woods from New Brunswick to Georgia, and westward. Fig. 34I. See No. 359

342. Avens. Geum canadense. (Rosaceae.) Rather coarse, often rough herbs, scarcely ever more than $2 \mathrm{ft}$. tall. Leaves compound or deeply cleft, the leaflets or divisions of the leaf of conspicuously unequal size, the terminal one always largest. This is true particularly of the basal leaves. Some of the stem leaves may have only 3 leaflets, but usually more. Flowers not numerous, in an open terminal cluster, each flower slender-stalked, white. Fruit usually bristly, the bristles with recurved tips. July. In woods. Nova Scotia and Ontario to Georgia, and westward. Fig. 342. There are 6 other species, one with yellow flowers, but they differ mostly in technical characters. See No. 347.

343. Flowers neither yellow nor white.

With two thrice-compound leaves; flowers greenish-purple ....

Leaves more than 2, simply compound

Sprawling weak bog plant ....... Purple Cinquefoil no. 345 Stems erect

Flowers about $1 / 4$ in. across, in large terminal cluster ...... .................... Queen-of-the-Prairie no. 346 Flowers about $I$ in. across; few and nodding

..................... Purple Avens no. 347

344. Blue Cohosh. Caulophyllum thalictroides. (Berberidaceae.) A smooth bluish green woodland herb, I-3 ft. tall, with only 2 leaves that are thrice compound, the leaflets suggesting Meadow-rue. One leaf is near the top of the stem, and the other and smaller one near the large terminal flower cluster. Flowers greenish-purple, with 6 petals and 6 sepals. In rich woods. New Brunswick to No. Carolina, and westward. May. Fig. 344. See also Nos. 501 and 508 

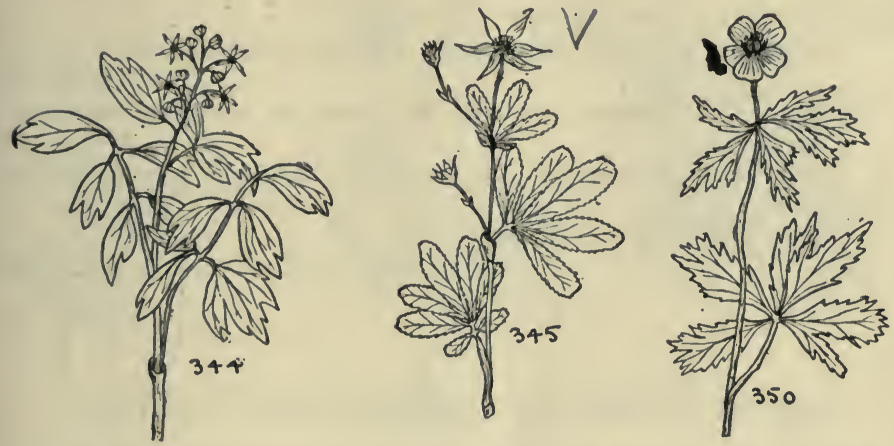

345. Purple Cinquefoil. Comarum palustre. (Potentilla palustris.) (Rosaceae.) A sprawling bog plant, somewhat woody at the base and not over I-2 $\mathrm{ft}$. long. Leaves compound, the 5-7 leaflets broadest towards the rounded tip, wedge-shaped at the base, sharply toothed. Flowers reddishpurple, showy, solitary, or in a few-flowered terminal cluster. Fruit dry. July. Greenland and Labrador to the highland parts of N. J., and westward. Fig. 345. See No. 359. 346. Queen-of-the-Prairie. Filipendula rubra. (Rosaceae.) An erect showy herb 2-8 ft. tall with a much branched grooved stem, and compound leaves. Leaflets usually $3-7$, but sometimes with smaller ones interspersed, deeply cut and sharply toothed. Flowers pink or purple, scarcely more than $1 / 4$ in. across, in a large open, much-branched cluster. Fruit a collection of dry, pointed capsules. July. In moist places. Western N. Y. to Georgia and Kentucky, thence westward to Illinois, Michigan and Iowa. Often cultivated eastward, and occurring as an escape. A white-flowered relative, F. Ulmaria, introduced from Europe and Asia is also found as a garden escape. It is about half the size and has leaflets that are whitewoolly on the under sicle. See No. 359 .

347. Purple Avens. Geum rivale. (Rosaceae.) Similar in general aspect to No. 342 (see Fig. 342 ), but with showy purple flowers. June. Moist places. Newfoundland to N. J., and westward. 
348. Flowers yellow. (Nos. 349-376.)

Leaflets or divisions of the leaf without marginal teeth ......

Leefl.................................... no. 370

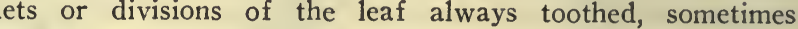
deeply so

Sepals united towards the base, only the tips free (See Fig.

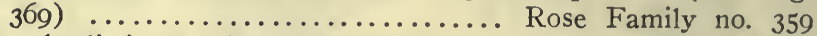

Sepals distinct and separate

............... Buttercups and Globe-flower no. 349

\section{BUTTERCUPS AND GLOBE-FLOWER}

Herbs with much divided, but not truly compound leaves, the segments always more or less toothed, sometimes deeply so, and in some species even dissected. (Not so in No. 35I.) Flowers solitary or in loose open clusters. Sepals separate and free to the base, sometimes colored and petal-like. Petals, when present, 5, not united. Fruits dry, pod-like and often short-beaked, I-seeded in the buttercups and several seeded in the Globe-flower (No. 350). (Ranunculaceae.) There is but one species of Globe-flower, but over thirty of the Buttercup, or Crowfoot, as it is often called. Of these only eight are considered here. In some species the basal leaves are rounded and uncut, while the stem leaves are divided. The Buttercups and Globe-flower may be separated thus:

Petals more or less incurved, the flower globe-like ............

............................... Globe-flower no. 350

Petals spreading, the flower not globe-like

Leaves uncut, toothless or nearly so .. Water Spearwort no. 351

Leaves, at least those on the stem cut or divided (some basal leaves uncut)

Flowers small, scarcely $1 / 4$ in. wide; basal leaves roundish and merely wavy-margined .... Kidney-leaved Crowfoot no. 352

Flowers mostly over $1 / 2$ in. wide; basal leaves cut or divided. Plants somewhat prostrate, rooting at the joints .........

Plants essentially erect

Leaf divisions deeply or much cut

Flowers about I in. wide; fruit short beaked

Roots fibrous ......... Meadow Buttercup no. 354

Roots bulbous ......... Bulbous Buttercup no. 355 

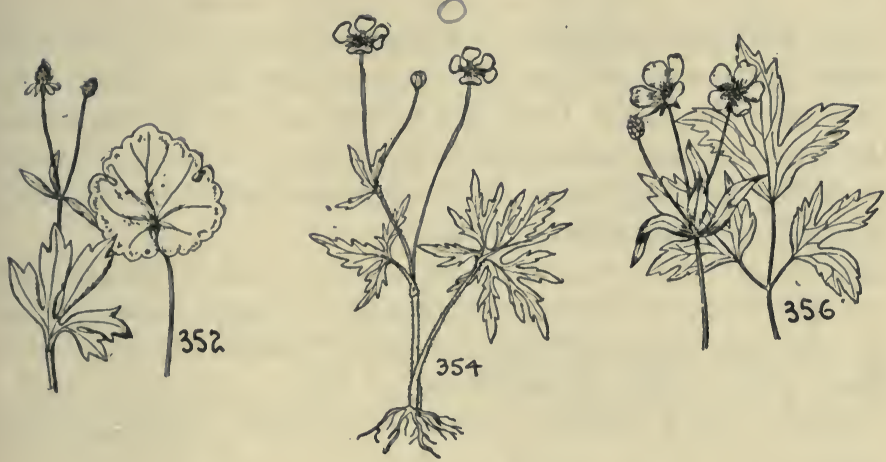

Flowers about $3 / 4$ in. wide; fruit long beaked ......... ..................... Marsh Buttercup no. 356 Leaf divisions not deeply cut

Flowers about $1 / 2$ in. wide ... Rough Buttercup no. 357 Flowers about I in. wide .... Hairy Buttercup no. 358 For other plants in this family see Nos. 238-240, 306, 309-31 I, 329, 338-339, 430, 440, 44I, 442, 498-499, 563, 564, 946.

350. Globe-Flower. Trollius laxus. A buttercup-like plant of wet meadows, with much divided leaves and a solitary flower. Petals slightly incurved, the flower thus appearing globe-like, pale lemon yellow. Fruit a collection of manyseeded dry beaked pods in a head-like cluster. Conn. to Delaware, and west to Michigan. June. Fig. $35^{\circ}$.

351. Water Spearwort. Ranunculus obtusiusculus. ( $R$. laxicaulis.) Buttercup-like, but with long, narrow, pointed stalkless, and uncut leaves, that may or may not have a few small marginal teeth. Flowers about $3 / 4$ in. wide, yellow, in a loose cluster. In marshes. Maine and Ontario to Georgia, and westward. July.

352. Kidney-leaved CRowfoot. Ranunculus abortions. A low plant not usually over 18 in. high, the basal leaves kidneyshaped, uncut and wavy margined. Stem leaves divided into wedge-shaped segments. Flowers not over $1 / 4$ in. wide, the petals inconspicuous. In moist places Labrador and Nova Scotia to Florida, and westward. May. Fig. 352. There are several closely related species with uncut and roundish basal leaves. 
353. Creeping Buttercup. Ranunculus repons. A sprawling weak Buttercup, with all its leaves cut or divided and often rooting at the joints. Divisions of the leaf, or sometimes only the terminal one, stalked. Flowers about $\mathrm{I}$ in. wide. Common in fields and roadsides, or in meadows. Newfoundland to Virginia, and westward. June.

354. Meadow Buttercup. Ramunculus acris. The tallest of our buttercups, often reaching $2 \mathrm{l} / 2 \mathrm{ft}$. high. Leaves much cut, the leaf-stalks and branches hairy. Roots fibrous. Flowers about I in. wide. In meadows or fields. Newfoundland to Virginia, and westward. Native of Europe. May-Sept. Fig. 354 .

355. Bulbous Buttercup. Ranunculus bulbosus. Similar to No. 354, but shorter, and with a bulbous-thickened root. In similar situations from New England to No. Carolina, and westward. May.

356. Marsh Buttercup. Ranunculus septentrionalis. An erect or weak Buttercup, sometimes rooting at the joints, witl 3 -divided leaves, the divisions mostly long-stalked. Flowers about $3 / 4$ in. wide, or slightly more. Fruit conspicuously long-beaked. May. In swamps or meadows. New Brunswick to Georgia, and westward. Fig. 356.

357. Rough Buttercup. Ranunculus recurvatus. A hairy Buttercup, with 3 -lobed leaves, that are otherwise scarcely divided, but toothed all around. Flowers small, pale yellow, scarcely over $1 / 2$ in. wide. The beak of the fruit is recurved, hence its Latin name. Moist woods. Nova Scotia to Florida, and westward. May.

358. Hairy Buttercup. Ranunculus hispidus. A densely hairy plant when young, less so later in the season. Leaves 3 -divided, the middle segment prominently stalked, none of them much cut or divided. Flowers about I in. wide. Beak of the fruit straight. In woods and thickets. Ontario to Georgia, and westward. April. Fig. 358.

\section{ROSE FAMILY. ROSACEAE.}

A large family of trees, shrubs, or herbs, with alternate leaves, which in the following are compound. Flowers soli- 
tary or in various sorts of clusters. Petals 5. Sepals united towards the base to form a cup-like receptacle (see Fig. 369), in this differing from the buttercup family, where the sepals are not united, but free. Fruit various.

Other plants of this family because of flower color, or other characters, will be found elsewhere. See Nos. 307, 337, $340-342,345-347,503,504$, and 519. The following may be distinguished thus :

Alpine plants known only from above timber line

Basal leaves broad, essentially undivided

Yellow Mountain Avens no. 360

All the leaves divided or cut ........ Alpine Cinquefoil no. $36 \mathrm{I}$

Plants not alpine

Stem leaves with 3 to 5 (rarely 7 ) leaflets that all arise at about the same point (See Fig. 362)

Plants essentially prostrate

Foliage silvery beneath, the leaflets both toothed and cleft..

..................... Silvery Cinquefoil no. 362

Foliage not silvery, the leaflets merely toothed.

Leaflets $3 \ldots \ldots \ldots \ldots \ldots$....... Mock Strawberry no. 363

Leaflets 5 ................ Cinquefoil no. 364

Plants erect

Leaflets 3 ............... Barren Strawberry no. 365

Leaflets 5 or $7 \ldots \ldots \ldots \ldots \ldots \ldots$. Cinquefoil no. 366

Stem leaves with an indefinite number of leaflets, often in opposite pairs, not all arising at the same point

Salt marsh plant with foliage silvery-hairy beneath .........

Silver Weed no. 367

Neither salt marsh, nor with foliage silvery beneath

Terminal leaflet conspicuously larger than the lateral ones; flowers few .................. Yellow Avens no. 368

Terminal leaflet of about the same size as the lateral ones;

flowers numerous in a tall spike ......... Agrimony no. 369

36o. Yellow Mountain Avens. Sicversia Peckii. (Geum Pcckii.) A low alpine herb, slightly hairy, with somewhat divided stem leaves, and esssentially undivided basal ones. Flowers few, about I in. across, yellow, the petals obviously but shallowly notched at the tip. Known only from, but not uncommon above timber line in the White Mountains of New Hampshire and from exposed slopes in Maine. August. 36r. Alpine Cinquefoil. Potentilla Robbinsiana. An alpine herb, somewhat woody at the base, scarcely more than 2 in. high, hairy. Leaves mostly basal, with three, toothed leaflets. 

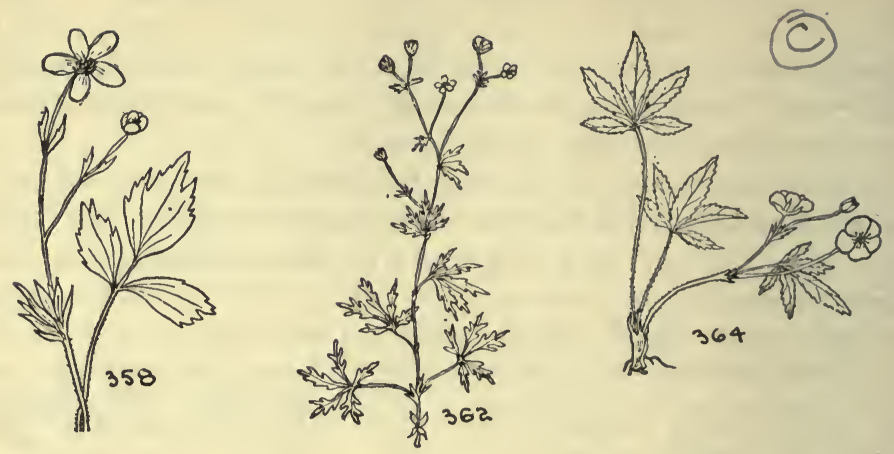

Flowers solitary, yellow, about $1 / 3$ in. wide. Confined to alpine summits of the White Mountains. August.

362. Silvery Cinqueforl. Potentilla argentea. A weedy, nearly prostrate plant of fields and roadsides with foliage silvery beneath. Leaves with five, toothed, and deeply cleft leaflets, all arranged finger-fashion. Flowers few, in a loose open terminal cluster, about $1 / 4$ in. wide. Nova Scotia and Ontario to Dist. of Columbia, and westward. May-Sept. Fig. 362.

363. Mock Strawberry. Duchesnea indica. A prostrate herb, often rooting at the joints, and much resembling the strawberry. Leaflets 3 , toothed but not cleft, silky-hairy, but not silvery. Flowers solitary at the leaf-joints, yellow, about $3 / 4$ in. broad. Fruit suggesting a strawberry, but dry and inedible. In waste places from N. Y. to Florida, and westward. Native of India. April-July.

364. Cinquefoil. Potentilla canadensis. A weak trailing herb with 5 leaflets to each leaf, all toothed and the stalklets arising at the same point. Flowers I or a few together, arising from the leaf joints, yellow, about $1 / 2$ in. broad. Fruit dry and inedible. In dry places. New Brunswick to Georgia, and westward. April-August. Fig. 364. There are two other closely related species all sometimes mistaken for the wild strawberry, but differing in the yellow flower, and dry fruits. 365. Barren Strawberry. Potentilla monspeliensis. A stout, stiff branched rough-hairy herb usually $12-18$ in. high. Leaf- 

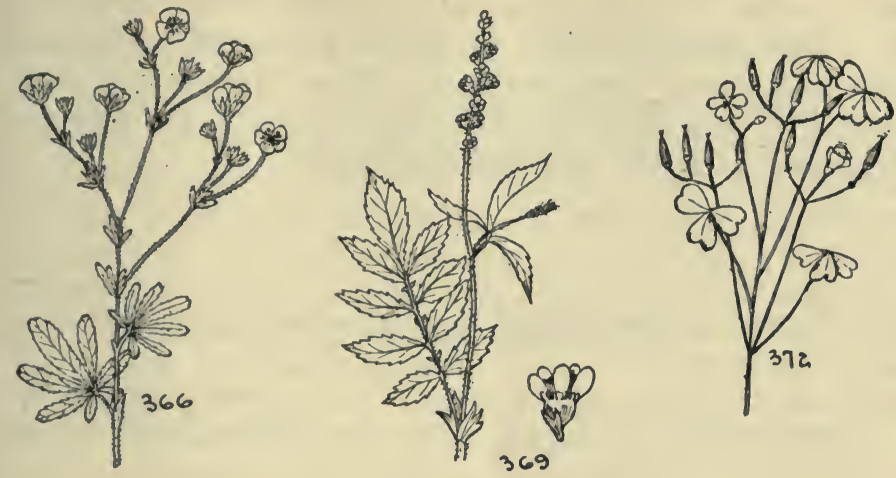

lets 3 , toothed. Flowers in a leafy terminal branched cluster, yellow, about $1 / 2$ in. across. Fruit dry. In dry places. Newfoundland and Labrador to So. Carolina, and westward. Also in tropical America, Europe and Asia. June-Sept.

366. Cinguefoil. Potentilla recta. Resembling the preceding, but with 5 or more leaflets. In waste places. Maine and Ontario to Virginia and Michigan. Native of Europe. JuneSept. Fig. 366.

367. Silver Weed. Argentina Anserina. (Potentilla Anserina.) A salt marsh herb, sometimes ascending into fresh water marshes. Plant not quite erect, often rooting at the joints. Leaves compound, the 9-25 leaflets all in opposite pairs, with an odd terminal one, toothed, stalkless, and silvery beneath. Flowers solitary, long-stalked, yellow, about $3 / 4$ in. wide. Fruit dry. From Greenland to N. J., and westward, where the typical salt marsh sort is replaced by closely related forms. May-Sept.

368. Yellow Avens. Geum strictum. With superficial resemblance to related white-flowered form (see Fig. 342), but with yellow flowers. In moist places. Newfoundland to Penn., and westward. July.

369. Agrimony. Agrimonia striata. A coarse stout roughhairy herb I-2 ft. tall and usually much branched. Stem leaves with 7 or 9 coarsely toothed leaflets in opposite pairs, often with smaller leaflets interspersed. Flowers about $1 / 4$ in. 
wide, yellow, in a long terminal spike-like cluster. Fruit dry, its bristles making it cling to clothes with some persistence. July. In thickets. New foundland to West Virginia, and westward. Fig. 369. There are five other species in the area distinguished by rather technical characters.

370. Leaflets or divisions of the leaf without marginal teeth. (Nos. 37 I-376.)

Leaflets $3 \ldots \ldots \ldots \ldots \ldots \ldots \ldots \ldots$. Wood Sorrel no. $37 \mathrm{I}$

Leaflets $8-30 \ldots \ldots \ldots \ldots \ldots \ldots \ldots . .$. Senna Family no. 374

\section{7r. WOOD SORREL. XANTHOXALIS. (OXALIS.)}

Rather weak, often sprawling herbs with branching stems and long stalked leaves. Leaflets 3, without marginal teeth, but usually notched, all arising from the same point, and essentially stalkless. Flowers in lax, few flowered clusters often exceeding the leaf-stalks in height, yellow. Petals 5 . Fruit an almost cylindrical, often angled, pod. (Oxalidaceae.) There are about ro species in the area, mostly distinguished by not very obvious characters. There are related plants at Nos. 505 and 506. The two here treated may be separated thus :

Pctals usually notched, pure yellow.

372. TAll WOOD Sorrel. Xanthoxalis cymosa. Usually erect, but sometimes spreading, the much branched stem often reddish or brown. Leaflets broadest towards the notched tip. Petals mostly notched, but faintly so, the flower about $3 / 4$ in. wide. In woods and fields. Ontario to Florida, and westward. May-October. Fig. 372.

Petals round, not notched, usually reddish at the base.

373. Yellow Wood Sorrel. Xanthoralis stricta. Much like No. 372, but the petals rounded and with a reddish base, making the flower "red-eyed." In woods and waste places. Nova Scotia to Florida, and westward. AprilOctober. 


\section{A GUIDE TO THE WILD FLOWERS}

374. SENNA FAMILY. CAESALPINIACEAE.

A large family of trees, shrubs and herbs, mostly tropical, but a few in temperate regions. Leaves alternate, compound, the leaflets usually numerous, without an odd one, lacking marginal teeth in the herbs treated below. Flowers yellow, not perfectly symmetrical but nearly so, having 5 petals of almost, but not quite, equal size. Fruit a pea-like pod. The species here treated may be distinguished thus:

Plants 3-5 ft. tall; leaflets stalked.

375. American Senna. Cassia marilandica. A tall stout, mostly unbranched herb, with compound leaves and yellow flowers, in small clusters. Leaves composed of 12-20 leaflets, the latter I-2 in. long, hairy on the margins, and short stalked. Flowers yellow, about $3 / 4$ in. wide. Pod about 3 in. long. In moist places. Mass. to No. Carolina, Tennessee and Ohio. July.

Plants 8-20 in. tall; leaflets essentially stalkless.

376. Sensitive Pea. Chamaecrista fasciculata. (Cassia Chamaecrista.) A weak, much branched and rather sprawling herb, with compound leaves, and a few yellow flowers, partly hidden by the foliage. Leaflets $20-30$, about $1 / 2$ in. long, stalkless, and slightly inequilateral. Flowers about $\mathrm{I}$ in. wide on stalks about I in. long. Pod about 2 in. long. In dry places. Mass. to Florida, and westward. August. Fig. 376. A closely related species, $C$. nictitans, has flowers about half as wide, and almost stalkless. It grows in similar situations from Maine to Georgia, and westward. In both species the leaflets are somewhat sensitive to the touch and to weather changes.

377. Petals or petal-like sepals 4 , or less than 4. (Nos. 378409.)

Flowers yellow ........................ no. 396

Flowerș white (rarely greenish or pinkish-white) ..... no. 38

Flowers neither white nor yellow

Flowers light purple; a fleshy plant of the sand-dunes ......

Sea Rocket no. 3:8 

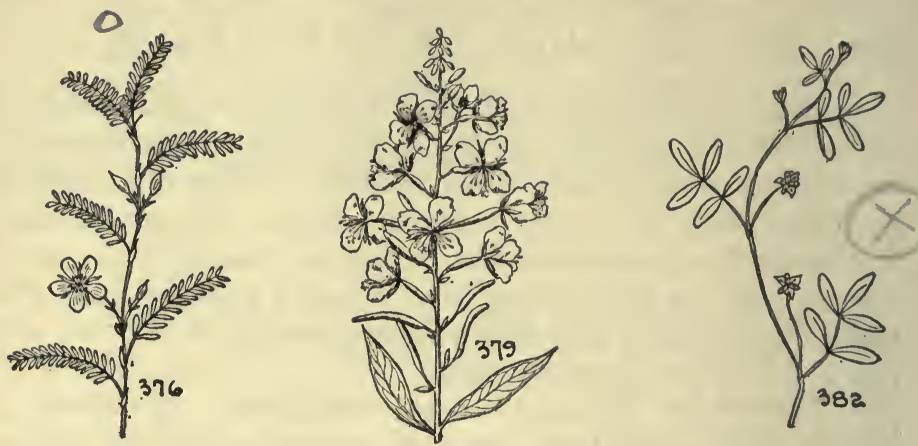

Flowers purple; a tall plant of sandy woods, often following a fire ....................... Fireweed no. 379 Flowers greenish, without petals; a marsh plant ........... 378. Sea Rocket. Cakile edentula. (Cruciferac.) A fleshy brittle plant of sea beaches; not over I ft. tall. Leaves more or less oblong, shallowly toothed, narrowed towards the base, 3-4 in. long. Flowers about $1 / 4$ in. across, purple, the 4 petals oblong. Pods about $3 / 4$ in. long. Newfoundland to Florida, and along shores of the Great Lakes. August. See. No. 383 .

379. FIREWEED. Chamaenerion angustifolium. (Epilobium angustifolium.) (Onagraceae.) Often called Willow-herb. A stout herb, 2-6 ft. tall, with alternate lance-shaped almost stalkless leaves, that are usually $3-5$ in. long. Flowers purple, in a long, terminal raceme. Fruit a pod about $2 \frac{1}{2}$ in. long. In dry places, especially after a forest fire. Greenland to No. Carolina, and westward. Also in Europe and Asia. JulySept. Fig. 379. (See Nos. 407-409, 434, 445.)

380. False Loosestrife. Ludwigia sphaerocarpa. (Onagraceac.) An erect marsh plant usually branched, and not over $3 \mathrm{ft}$. high. Leaves alternate, lance-shaped, pointed both ends, stalkless, and about 3 in. long. Flowers solitary at the upper leaf-joints, greenish, without petals, about $1 / 8$ in. wide, stalkless. Sepals 4, united below. In wet places. Mass. to N. Y. and Florida, and along the Gulf to Louisiana. August. See Nos. 407-409, 434, 445 . 
38r. Flowers white (rarely greenish or purplish-white).

Petals $3 \ldots \ldots \ldots \ldots \ldots \ldots \ldots$. False Mermaid no. 382

Petals 4 ................... Mustard Family no. 383 382. False Mermaid. Floerkea proserpinacoides. (Limnanthaceae.) A slender weak annual herb, not over I2 in. long growing in marshes and along streams. Leaves thin and weak, deeply divided into 3 or 5 narrow toothless segments. Flowers white, about $1 / 8$ in. broad, solitary at the end of long stalks from each of the upper leaf-joints. Petals and sepals 3. Quebec and Ontario to Delaware, Tennessee, and westward. May. Fig. 382.

\section{MUSTARD FAMILY. CRUCIFERAE.}

A huge family of plants, practically all herbs with a bitter but never poisonous juice. Leaves always alternate, simple or much divided, or even compound, the stem leaves often different from the basal ones. Flowers practically always in clusters, often in racemes, of various colors; but only the white-flowered species are treated here. Petals 4 , in the form of a cross, - - hence the Latin family name. Fruit always a dry pod, sometimes long and thin, or short and stout. The species are difficult to tell apart from flowers only, but as they are usually found with both flowers and fruits the latter can be relied upon to help in their identification. For other species of this family see Nos. $378,397-403,406$. The whiteflowered sorts may be distingushed thus:

Pods round or oval, three times longer than broad, or less

Plant 2-3 ft. tall; flowers about $\mathrm{I}$ in. wide .. Horseradish no. 384

Plants less than 18 in. tall; flowers about $1 / 4$ in. wide or less Pods about $1 / 4$ in. wide or less

Upper leaves stem-clasping .......... Field Cress no. 385

Upper leaves not stem-clasping, merely stalked ..........

Pods about $1 / 2$ in. wide, almost round $\ldots \ldots \ldots \ldots \ldots . . . . . .$.

Pods long and narrow, many times longer than thick

All the leaves broad, oval or triangular, not divided or cu; plant $\mathrm{I}-3 \mathrm{ft}$. high ................ Hedge Garlic no. 388

Leaves, or some of them, narrow, not triangular, or oval, often cut or divided 

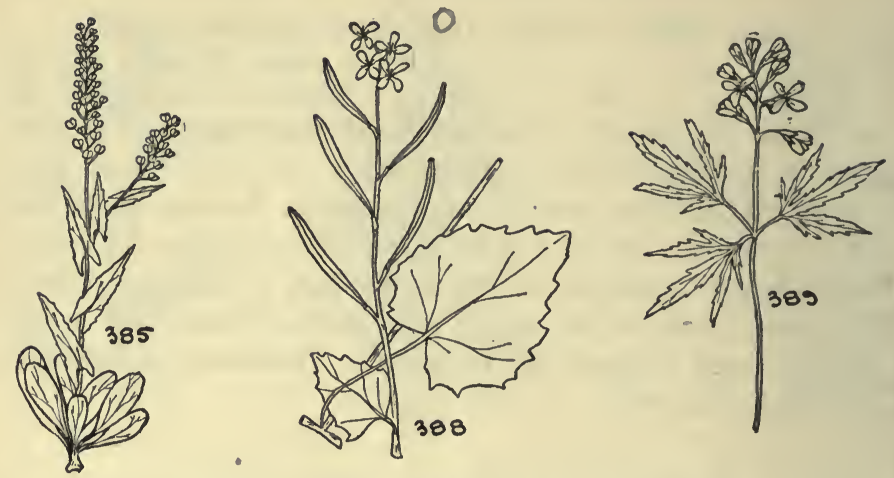

Stem leaves cut or divided

Stem leaves divided finger-fashion, the segments toothed ..

......................... Pepper-root no. 389

Stem leaves divided feather-fashion

Flowers about $1 / 2-3 / 4$ in. wide

.... Meadow Bitter-cress no. 390

Flowers about $1 / 4$ in. wide ........ Bitter-cress no. 39I Stem leaves neither cut nor divided

Basal leaves essentially round and long-stalked ........

...................... Bulbous Cress no. 392

Basal leaves not round, not long-stalked, merely narrowed toward the base

Stem leaves clasping the stem

Foliage bluish-green, smooth

................ Smooth Rock-cress no. 393

Foliage green, hairy ...... Hairy Rock-cress no. 394

Stem leaves not clasping the stem .. Rock-cress no. 395 384. Horseradish. Armoracia Armoracia. (Radicula Armoracia.) A stout perennial from thick deep roots which furnish the condiment. Basal leaves 9-I 5 in. long, oblong, finely toothed. Stem leaves $1 / 4$ as large, narrowly oblong, or lanceshaped. Flowers white, in clustered racemes, about I in. broad. Fruit an almost globe-shaped, beaked pod. Cultivated and often escaping. Native of Europe. August.

385. Field Cress. Lepidium campestre. An erect densely hairy weed about I4 in. high. Basal leaves broadest towards the tip, narrowed at the base. Stem leaves clasping the stem, about $2 \frac{1}{2}$ in. long, often slightly tooth^d. Flowers about $1 / 4$ 
in. wide, in a dense terminal raceme, white. Pods very numerous, broadly oval, not over $1 / 4$ in. wide. In fields and waste places. New Brunswick and Ontario to Virginia, and westward. May-July. Fig. 385 .

386. Wild PEPPER-GRASS. Lepidium virginicum. Very like the preceding, but the stem leaves short stalked and not clasping the stem, the basal leaves cut into small segments towards the base. In fields and waste places almost throughout North America as a common weed. May-November. There are several other closely related species.

387. Field Penny-Cress. Thlaspi arvense. An erect herb, usually unbranched and under I 8 in. high. Basal leaves nearly oblong, but broadest towards the tip. Stem leaves clasping the stem, broadly and shallowly toothed. Flowers white, very small, in a terminal raceme. Fruit nearly round, about $1 / 2$ in. in diameter, distinctly notched at the tip. In waste places. Quebec to N. Y., and westward. Native of Europe and Asia. June-August.

388. Hedge Garlic. Alliaria Alliaria. (Alliaria officinalis.) An erect often branched herb $\mathrm{I}-3 \mathrm{ft}$. tall wth broad alternate long stalked leaves, which are oval or triangular, coarsely but not sharply toothed, and $2-7$ in. long. Flowers about $1 / 4$ in. wide, white. Fruit about $\mathrm{I} 1 / 2$ in. long, scarcely $1 / 10$ in. thick, on a stout stalk. In waste places. Quebec and Ontario to Virginia. Native of Europe. May. Fig. 388.

389. Pepper-root. Dentaria laciniata. A low woodland plant, not over ${ }_{5}$ in. tall. Leaves usually 3 , all stalked, deeply cut, or divided finger-fashion, the segments toothed. Flowers white, or whitish-pink, alsout $3 / 4$ in. wide, in a loose terminal cluster. Pods slender, about $I \frac{1}{2}$ in. long. Quebec to Florida, and westward. May. Fig. 389. A related species, of which there are several, is $D$. diphylla. It has mostly 2 stem leaves which are 3 -divided, but not deeply cut, and is found in woods. Nova Scotia and New Brunswick to So. Carolina, and westward.

390. Meadow Bitter-Cress. Cardamine pratensis. A smooth swamp or meadow plant with apparently compound leaves actually deeply divided, feather-fashion. Segments of the 

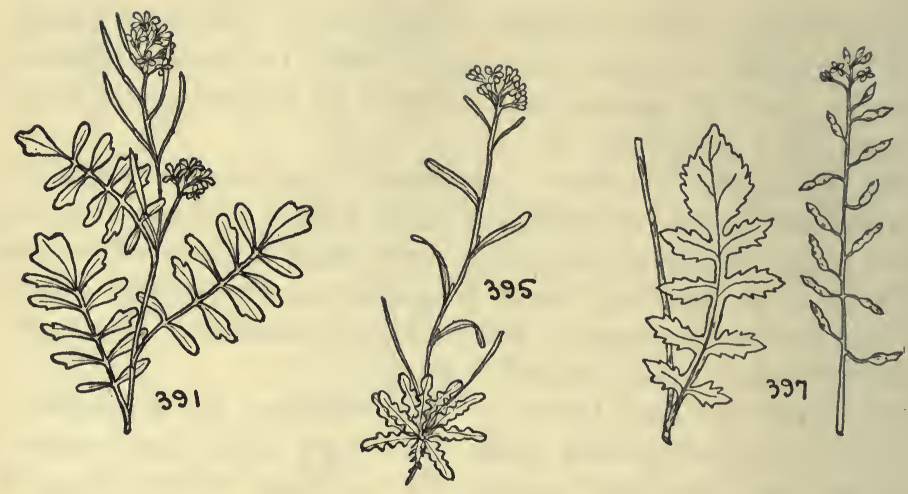

basal leaves about three times as broad as the stem leaves. Flowers about $3 / 4$ in. wide, white, or whitish-pink, in a terminal cluster. Pods slender, about I in. long. Labrador to N. J., and wesward. May.

391. BitTer-CREss. Cardamine pennsylvanica. Much like No. 390 , but the flowers about $1 / 4$ in. wide. In wet places. Newfoundland to Florida, and westward. May. Fig. 391. There are several other species, some growing on dry land, but mostly in wet places.

392. Bulbous Cress. Cardamine bulbosa. Unlike Nos. 390 or $39 \mathrm{I}$ in having round, undivided, long-stalked basal leaves, and oblong merely toothed stem leaves. Flowers about $1 / 2$ in, wide, white. Pods stiffly erect, about $I$ in. long. In wet places. Vermont and southern Ontario to Florida, and westward. May.

393. Smooth Rock-cress. Arabis laevigata. A bluish-green completely smooth herb I-3 ft. tall, usually unbranched. Basal leaves, broadest towards the tip, narrowed towards the base, toothed, 2-3 in. long; stem leaves oblong conspicuously stem-clasping, toothed but not much so. Flowers greenishwhite, scarcely $1 / 4$ in. wide. Pods lax, or even recurved, 3-4 in. long. Rocky woods, Quebec and Ontario to Georgia, and westward. May.

394. Hairy Rock-cress. Arabis hirsuta. Somewhat similar to No. 393, but usually rough hairy throughout. Basal leaves 
more nearly oblong, and the stem leaves more plentiful. Pods about $I \frac{I}{2}$ in. long, stiffly erect. Among rocks. New Brunswick to Georgia, and westward. May-Sept. There are several related species.

395. Rock-CREss. Arabis lyrata. A weak herb, scarcely 12 in. tall. Basal leaves cut or divided, suggesting a lyre, I-2 in. long. Stem leaves not clasping the stem, practically toothless and undivided, about $3 / 4$ in. long. Flowers scarcely $1 / 4$ in. wide, in a terminal cluster, white. Pods about I in. long, ascending, but scarcely stiffly erect. In rocky or sandy places. Ontario to Tennessee, and westward. April-Sept. Fig. 395.

396. Flowers yellow. (Nos. 397-409.)

Leaves undivided, not cut or compound ........... no. 405

Leaves cut, divided, or compound

Plants without conspicuously yellow juice

Pods about 3 times as long as broad

Yellow Water-cress no. 397

Pods about 8 or io times as long as broad

Pods conspicuously pinched between the seeds

Pods covered with stiff hairs .. White Mustard no. 398

Pods scarcely hairy ........... Wild Radish no. 399 Pods not pinched, or only slightly so

Pods about $1 / 2$ in. long

Leaf lobes pointing backward . Hedge Mustard no. 400

Leaf lobes not pointing backward

Pods $I$ in. or more long

Plants 2-4 ft. high ....... Tall Sisymbrium no. 402

Plants about $\mathrm{I} 8 \mathrm{in}$. high or less . Yellow Rocket no. 403

Plant with conspicuously yellow juice ...... Celandine no. 404 397. Yellow Water-CRess. Radicula palustris. A branching smooth herb with deeply cut leaves, the segments toothed. Lower leaves stalked, 3-6 in. long, the upper ones nearly stalkless and smaller. Flowers yellow, about $1 / 8$ in. wide, in a long terminal cluster. Pods about $I$ in. long, 3 times as long as broad. Throughout North America in wet places. MayAugust. Fig. 397. There are several related species, one of them, $R$. hispida, has a hairy stem, and frequently grows $4 \mathrm{ft}$. tall. It is found in wet places from New Brunswick to 

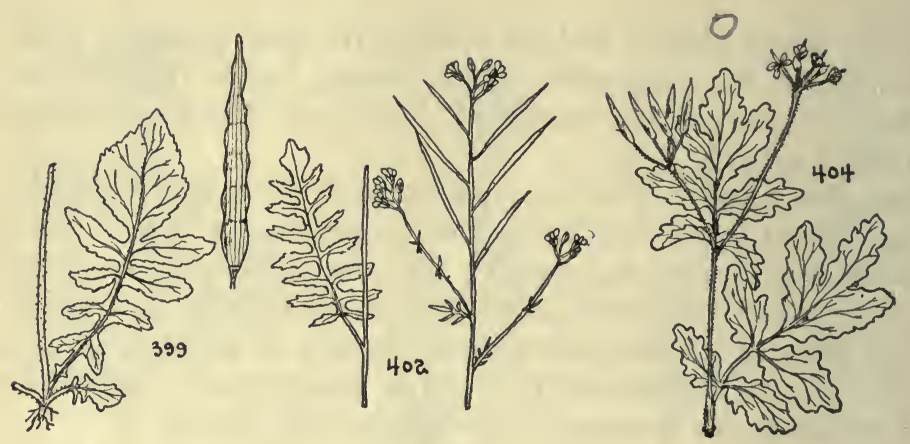

Florida, and westward. For true water-cress see No. 948. See also, No. 383 .

398. White Mustard. Sinapis alba. (Brassica alba) A weedy plant of waste places, scarcely $2 \mathrm{ft}$. tall. Leaves divided, the terminal segment larger than the lateral ones. Flowers yellow, about $1 / 2$ in. wide, in a terminal raceme. Fruit a hairy pod, about 2 in. long, prominently constricted between the seeds. Often as an escape from gardens. Native of Europe. August. A related species, the Charlock, $S$. arvensis, has almost undivided leaves and grows in similar places. See No. 383 .

399. Wild Radish. Raphanus raphanistrum. Often a troublesome weedy plant, I-2 ft. high. Lower leaves deeply cut and lobed, 4-7 in. long, the terminal lobe the largest. Upper leaves smaller, few, and mostly not lobed or cut. Flowers yellow, about $1 / 2$ in. wide. Pod about $I \frac{I}{2}$ in. long, smooth, constricted between the seeds. Ontario and Newfoundland to Penn. August. Fig. 399. See No. 383 .

40o. Hedge Mustard. Erysimum officinale. (Sisymbrium officinale.) An erect stiff, mostly hairy, plant, I-3 ft. tall. Leaves deeply divided, the terminal segments pointed and oblong, the lateral ones curved towards the base of the leaf, all irregularly toothed. Flowers yellow, less than $1 / 8$ in. broad. Pods about $1 / 2$ in. long, tightly pressed against the stalk. A common weed in waste places, nearly throughout North America. Native of Europe and Asia. May-October. See No. 383 . 
40r. Black Mustard. Brassica nigra. A much branched coarse herb, 2-6 ft. high. Lower leaves deeply lobed, the terminal segment much larger than the lateral ones. Upper leaves less cut and smaller, those near the flower cluster uncut. Flowers in a terminal raceme, yellow, about $1 / 4$ in. wide. Pods $1 / 2$ in. long, pressed against the stalk. In waste places throughout North America. Native of Europe and Asia. June-October. There are several weedy relatives. See No. 383 .

402. Tumble Mustard. Norta altissima. (Sisymbrium altissimum.) A tall weedy herb, often reaching $5 \mathrm{ft}$. high. Leaves much lobed, but the lobes approximately of equal size, not much toothed. Flowers about $1 \%$ in. wide, yellow, in a terminal raceme. Pods lax, arching, about 3 in. long. In waste places. Nova Scotia and Ontario to Virginia, and westward. August. Fig. 402. See No. 383 .

403. Yellow Rocket. Barbarea Barbarea. (B. vulgaris.) A weed of waste places, usually I-2 ft. high. Lower leaves stalked, 2-4 in. long, cut and lobed. Terminal lobe many times larger than the I-4 pairs of lateral ones. Flowers yellow, about $1 / 3$ in. wide, in a terminal raceme. Pods about $I$ in. long, standing out from the stalk. Labrador to Virginia and, more rarely, westward. May. A related species, $B$. stricta, has stiffly erect pods tightly pressed against the stalk. See No. 383 .

404. Celandine. Chelidonium majus. (Papaveraceac.) A weak herb, I-2 ft. high, with conspicuously yellow juice. Leaves $4-6$ in. long, much divided, bluish-green on the under surface. Flowers yellow, about $1 / 2$ in. wide, in a small roundish cluster, from the leaf-joints, not at the ends of the branchlets. Petals 4, sepals 2. Fruit a stalked pod, I-2 in. long. In fields, waste places, or sometimes in woods. Ontario and Maine to Penn. and No. Carolina. Native of Europe. May-October. Fig. 404. See Nos. 333 and 500.

405. Leaves undivided, not cut or compound.

Flowers about $1 / 4$ in. wide; leaves stem clasping ............

Gold of Pleasure no. 406 

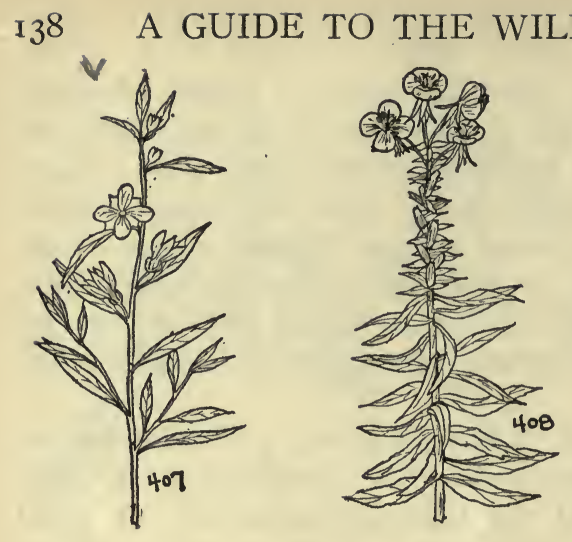

\section{FLOWERS}

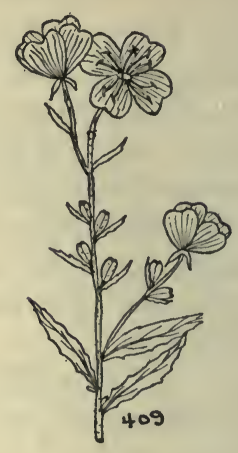

Flowers $3 / 4$ in. wide or more

Flowers solitary at the leaf-joints ....... Rattle-box no. 407 Flowers in clusters

Night flowering, closing in sunlight $\ldots \ldots \ldots \ldots \ldots \ldots$

...................... Evening Primrose no. 408

Day flowering, closing in the evening .... Sundrops no. 409 406. Gold of Pleasure. Camelina sativa. (Cruciferae.) An erect herb, I-8 ft. high, not usually branched. Leaves $2-3$ in. long, pointed at the tip, broadest towards the stem-clasping base. Flowers yellow, about $1 / 4$ in. wide, in a terminal raceme. Pod pear-shaped, but long beaked, about $1 / 4$ in. long. In waste places nearly throughout our area. June. Native of Europe. See No. 383 .

407. Rattle-Box. Ludwigia alternifolia. (Onagraceae.) A branching swamp or marsh herb, 2-3 ft. high, with alternate toothless leaves that are lance-shaped, and $2-4$ in. long, essentially stalkless. Flowers solitary at the leaf-joints, about $3 / 4$ in. wide, yellow. Petals 4 , sepals more or less united. Fruit a capsule, cube-shaped, crowned with the remains of the flower. June-Sept. Ontario to Florida, and westward. Fig. 407. See Nos. 379, 380, 434, 445.

408. Evening Primrose. Oenothera biennis. (Onagraceae.) A stout herb, simple or branched, I- $6 \mathrm{ft}$. tall with alternate, mostly lance-shaped leaves, I-6 in. long, faintly and irregularly toothed and essentially stalkless. Flowers in a terminal 
leafy spike, night-flowering, yellow, about $\mathrm{I}$ in. wide, petals 4. Sepals united into a tube. Fruit a stout pod, longer than the small leaves, among which it grows. In dry places, Labrador to Florida and westward. June to Sept. Fig. 408. Common as a weed, as are also several of its closely related forms. See Nos. 379, 380, 434, 445 .

409. Sundrops. Kneiffia fruticosa. (Oenothera fruticosa.) (Onagraceae.) Erect or sometimes weak herbs, I-3 ft. tall with alternate lance-shaped essentially stalkless leaves, I-3 in. long. Flowers in a sparse open cluster, few-flowered. Petals 4, yellow, opening in sunlight. Sepals united into a tube. Fruit a stalked or stalkless pod, usually largest towards its tip, not over $3 / 4$ in. long. In dry places. New Brunswick to Georgia, and westward. July. Fig. 409. There are several closely related forms.

4I0. Leaves all opposite, or with more than 2 at each joint. (Nos. 4I I-482.)

Flowers yellow .......................... no. 465

Flowers white (rarely greenish or pinkish) .......... no. 439

Flowers neither yellow nor white

Petals, or petal-like sepals, 4, (sometimes 5 in Viorna ochroleuca No. 430) ......................... no. 429

Petals, or petal-like sepals 5 or more

Leaves cut, or lobed, or divided, or toothed

Leaves not cut, or divided or toothed

Geraniums no. 425

Plants with distinctly swollen joints

Joints not swollen, or if so, only slightly

Essentially prostrate plant of dry sand; juice milky .. Wild Ipecac no. 419

Plants erect or sprawling; juice not milky

Stamens about the same number as the petals ......

Sabbatias no. 415

Stamens more numerous than the petals, usually much more

Leaves distinctly stalked

Leaf-stalks $3 / 4$ in. long; growing in dry places .. 

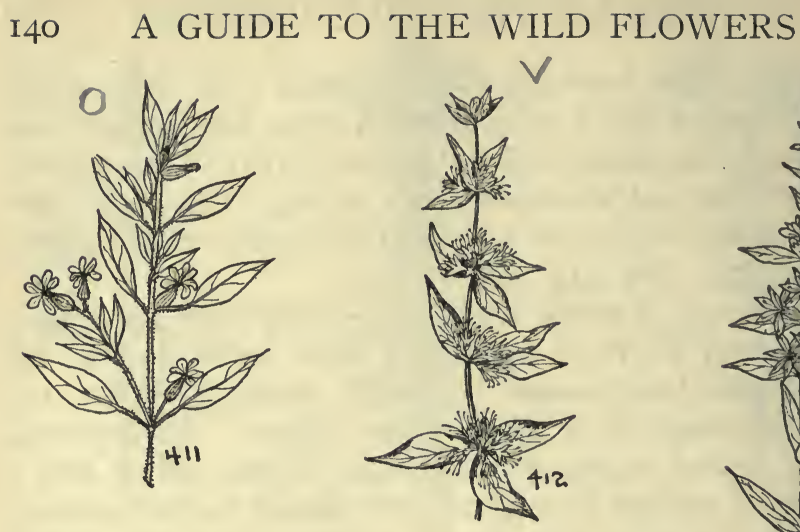

Leaf-stalks $1 / 8$ in. long; growing in swamps or
water ........ Swamp Loosestrife no. 412

Leaf-stalks $1 / 8$ in. long; growing in swamps or
water ........ Swamp Loosestrife no. 412 Leaves not stalked

Leaves oval-oblong, black-dotted ............. Marsh St. John's-wort no. 4I3 Leaves narrower, not black-dotted

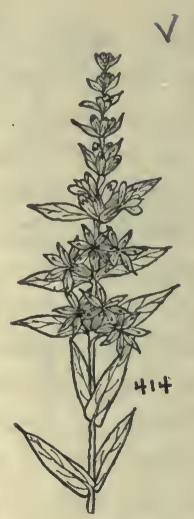
............... Purple Loosestrife no. 4I4 4II. TAR-WeEd. Parsonsia petiolata. (Cuphea petiolata.) (Lythraceae.) An opposite leaved sticky herb, 6-I 8 in. tall, with leaf-stalks about $3 / 4$ in. long. Flowers at the leaf-joints, slightly unsymmetrical, purple. Petals 6, stamens I I or I2. Fruit a dry pod. In dry places. New Hampshire to Georgia, and westward. July-Sept. Fig. 4I I.

412. Swamp Loosestrife. Decodon verticillatus. (Lythraceac.) A coarse almost woody perennial, 3-6 ft. tall, with lance-shaped leaves on stalks about $\mathrm{r} / 8$ in. long. Leaves $2-4$ in. long, often 3 at each joint. Flowers purple, in dense stalkless clusters from the upper leaf-joints. Stamens prominent, protruding. In wet places. Maine and Ontario to Florida and westward. August. Fig. 4I2.

4I3. Marsh St. John's-WORT. Triadenum virginicum. (Hypericum virginicum.) (Hypericaceac.) A smooth, oppositeleaved herb, with conspicuously black dotted foliage. Leaves oval-oblong, essentially stalkless, bluish-green beneath, I I $/ 2-$ $2 \mathrm{~T} / 2$ in. long. Flowers mostly in short-stalked terminal clusters, greenish-purple, about $1 / 2$ in. wide. Fruit a pointed, 
reddish purple capsule. Wet places. Newfoundland to Florida, and westward. August. See Nos. 472 and 483.

414. Purple LoosestriFe. Lythrum Salicaria. (Lythraccae.) A much branched herb of wet places, often $3 \mathrm{ft}$. tall. Leaves opposite or sometimes in 3's, lance-shaped, 2-3 in. long. Flowers purple, about $1 / 2$ in. wide, in a long leafy terminal spike, very showy. Canada to Delaware. July. A native of Europe, but thoroughly at home here, particularly along some of our tidal streams. Fig. 4I4.

\section{I5. SABBATIAS. SABBATIA.}

Smooth, slender, often somewhat sprawling herbs, with the leaves opposite, or arranged in 3's, wholly without teeth. Flowers rose pink, rarely whitish, solitary, or in few-flowered clusters. Sepals usually $6-8$, united below, but free above, long and narrow. Petals essentially separated, but actually united at the base. Stamens about the same number as the petals. Fruit a many seeded dry pod which is often much exceeded by the persistent sepals. (Gentianaceac.) There are about ro species of which the following may be distinguished thus :

Petals not over 6

Branches opposite ................... Bitter-bloom no. $4 \mathrm{I} 6$

Branches alternate ................... Sea Pink no. 4I7

Petals $8-12 \ldots \ldots \ldots \ldots \ldots \ldots \ldots \ldots . . \ldots$ Marsh Pink no. 418

(See also Nos. 671 and 805)

4r6. Bitter-Bloom. Sabbatia angularis. A much branched slender herb with a distinctly 4-angled stem. Upper branches always opposite, some of the lower occasionally alternate. Leaves oval, pointed at the tip, broadest towards, and stemclasping at the base. Flowers rose pink, mostly solitary, about $I \frac{1}{2}$ in. wide. In open rich places. Ontario and N. Y. to Florida, and westward. July. A related species, S. lanccolata, with more spreading, and white, petals, is found in the pine barrens from N. J. to Florida.

4I7. Sea pink. Sabbatia stellaris. Similar to No. 4I6, but with alternate branches, and leaves not broadest towards the 

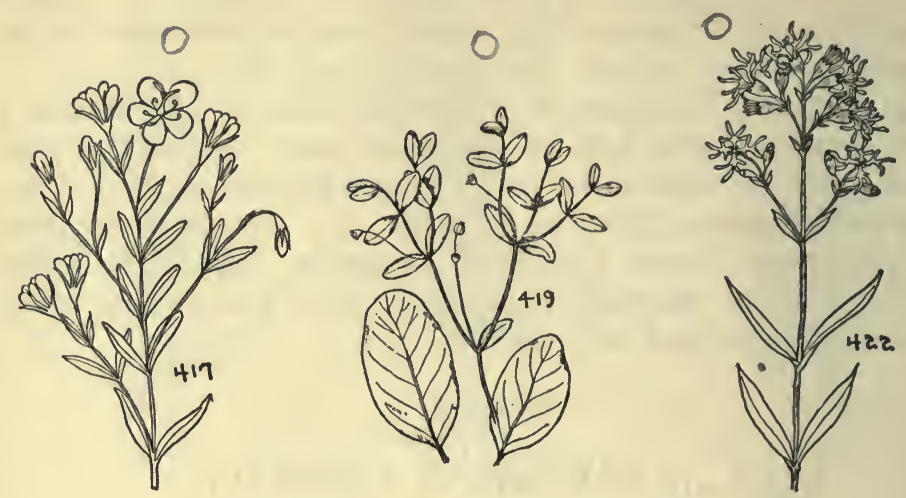

base. Common in salt marshes. New England to Florida. August. Fig. 4I7.

4I8. Marsh Pink. Sabbatia dodecandra. Similar to 4I7, but with narrower stem leaves, and with 8 to 12 petals. In or near salt marshes. Mass. to No. Carolina, often very common. August.

4I9. Wild Ipecac. Tithymalopsis Ipecacuanhae. (Euphorbia Ipecacuanhae.) (Euphorbiaceac.) A deeply rooted perennial, the root often descending $3 \mathrm{ft}$. in pure sand. Leaves the most variable in size, shape and color of any wild plant,always opposite, without teeth and with a milky juice. They may vary from round to thread-like, and from brilliant red, through orange or yellow, to green. Flowers solitary, on a long stalk from the leaf bases, scarcely $1 / 4$ in. across, pinkish purple. In sand. Conn. to Florida, near the coast, and in locally sandy places in the interior. June-Sept. Fig. 419. See also 252, 268, 278, 447, and 528-530.

420. PINK FAMILY. CARYOPHYLLACEAE.

Annual or perennial, often weedy herbs, with opposite, toothless, leaves and swollen joints, like the carnation of the florists. There are usually 5 sepals, united into a tube which 
swells in some species into a bladdery pod. Petals 5 , sometimes notched or fringed, of various colors. Stamens twice as many as the petals. There are many species and genera. For related forms see Nos. 450, 456, 460, 524, and 525. The four following may be differentiated thus:

Petals distinctly cut or fringed

Flowers clustered

Petals finely cut; flower about $1 / 4$ in. across $\ldots \ldots \ldots \ldots \ldots$. Deptford Pink no. 42I Petals deeply cut; flower about $3 / 4$ in. across .............. .Cuckoo Flower no. 422

Flowers solitary .................. Meadow Pink no. 423

Petals merely notched, shallowly so ........ Corn Cockle no. 424 42 r. Deptrord Pink. Dianthus Armeria. A European garden plant that escapes to roadsides and waste places. A stiff, finely hairy annual, not over 15 in. high. Leaves opposite, linear, I-3 in. long. Flowers in a close rather leafy terminal cluster, pink. Petals finely cut. Quebec and Ontario to Virginia, and westward. August.

422. Cuckoo Flower. Lychnis Flos-cuculi. A European garden plant often escaping to moist places, freely branching, and somewhat sticky above. Leaves linear, or lance-linear, 2-3 in. long, but much reduced towards the top of the plant. Flowers pink, very rarely blue or white, in a rather loose, terminal, essentially leafless cluster. Petals deeply cut into 4 linear lobes. New Brunswick to N. J. and Penn. JuneSept. Fig. 422. See No. 456 for a related species.

423. Meadow Pink. Dianthus deltoides. A free flowering perennial, growing in clumps, the stems branching, 6-12 in. tall. Leaves linear, scarcely $\mathrm{I}$ in. long, erect towards the top of the stem. Flowers pink, about $3 / 4$ in. wide, solitary at the ends of the branches, the petals finely toothed or fringed. In waste places. Néw England and northern N. Y. to Michigan. August.

424. Corn Cockle. Agrostemma Githago. An erect, rarely branched, densely white-hairy plant, I-3 ft. tall. Leaves $2-4$ in. long, about $1 / 4$ in. wide. Flower solitary, bright red, I-2 in. wide, much exceeded by the long narrow sepals. In waste places, almost throughout North America. Native of Europe. July-Sept. Fig. 424. 

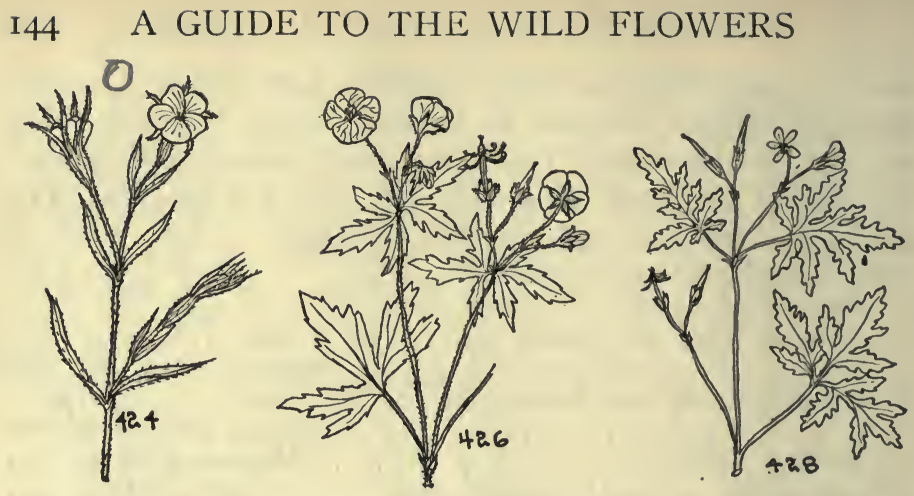

\section{GERANIUM OR CRANE'S-BILL.} (GERANIACEAE.)

Herbs with divided or much cut foliage. Leaves basal and on the stem, the latter opposite. Flowers solitary, or in clusters, pink or red in the species here treated, sepals 5, petals 5. Fruit a dry pod, its divisions curiously long stalked at maturity. (See Fig. 426.) All are known as geraniums. The three following are distinguished thus:

Flowers about $\mathrm{I}$ in. wide ............ Wild Crane's-bill no. 426

Flowers about $1 / 2$ in. wide or less

Flowers in compact clusters ...... Carolina Crane's-bill no. 427

Flowers only 2 together ............. Herb Robert no. 428 426. Wild Crane's-bill. Gcranium maculatum. One of our commonest woodland wild flowers. Perennial, hairy, not usually over $\mathrm{I} 8$ in. tall. There are 2 opposite stem leaves, and basal ones, all cleft, finger-fashion, almost to the center, the lobes toothed towards the tip. Flowers in a loose open fewflowered cluster. Petals rose-purple. Maine and Ontario to Georgia, and westward. May-June. Fig. 426.

427. Carolina Crane's-bill. Geranium caroliniamum. Resembling No. 426 , but with more finely cut leaves, and pale pink flowers, about one half the size, but in compact clusters. In dry places. Ontario to Florida and westward. May-July. 428. Herb Robert. Robertiella Robertiana. (Geranium Robertianum.) A weak sprawling rather sticky herb, the foliage 
odorous. Leaves opposite, much cut and divided, the ultimate divisions toothed. Flowers in pairs at the end of a long slender stalk, not over $1 / 2$ in. wide, reddish-purple. Among rocks, Nova Scotia to Penn., and westward. May-Sept. Fig. 428.

429. Petals or petal-like sepals 4 (sometimes 5 in Viorna ochroleuca no. 430.

Petals none; sepals greenish-purple, petal-like; flowers nodding; plant silky $\ldots \ldots \ldots \ldots \ldots \ldots \ldots$. Leather-Flower no. 430

Petals present, showy; plant not silky

Leaves conspicuously 3 or 5 nerved .. Meadow Beauty no. 43I Leaves not conspicuously 3 or 5 nerved; fruits a long slender down-filled pod .................. Willow Herbs no. 434 430. LeATHER-FLOWER. Viorna ochroleuca. (Clematis ochroleuca.) (Ranunculaceae.) An erect relative of Nos. 239 and 240 , which are vines, and have compound leaves. See No. 237 for description of the genus. In sand and on serpentine outcrops. Staten Island to Penn. and Georgia, rather local. May.

\section{I. MEADOW BEAUTY. RHEXIA. (MELASTOMACEAE.)}

Low, rather weak herbs, with opposite leaves and rough or angled stems. Leaves mostly stalkless, prominently 3-5 nerved, and rather sharply toothed, but not deeply so. Flowers $\mathrm{I}$, or few in a terminal cluster, more or less oblique and appearing not quite regular. Petals 4, showy, magentapurple. The species here treated are:

Stems round, rough-hairy.

432. Meadow beauty. Rhexia mariana. A bristly hairy herb, simple or branched, with opposite, essentially stalkless leaves which are oblong, or linear-oblong, and $I-I^{1} / 2$ in. long. Flowers pale magenta-purple, about I in. wide. In pine barren bogs. Long Island to Floricla, and westward. July.

Stem angled, smooth or with a few hairs. 


\section{I46 A GUIDE TO THE WILD FLOWERS}
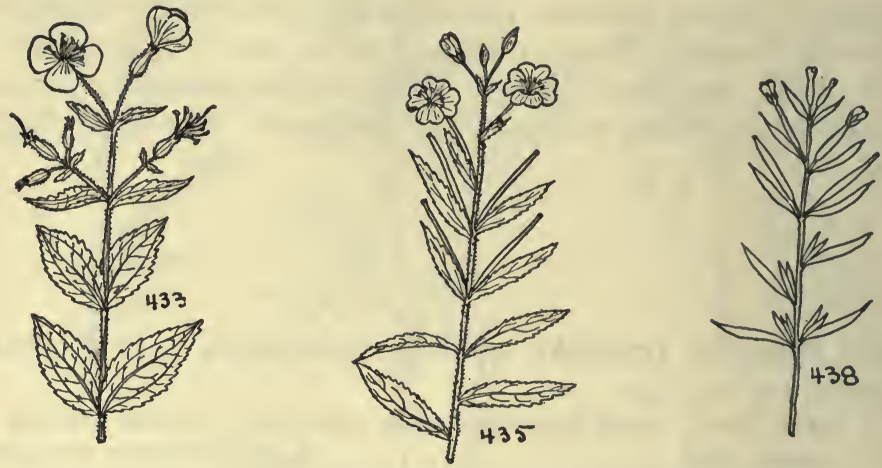

433. Meadow beauty. Rhexia virginica. Similar to No. 432, but with broader leaves, and much more common. In wet open places. Ontario and Maine to Florida, and westward. August. Fig. 433. A plant closely related to Nos. 432 and 433 is $R$. aristosa, which differs from both in having each petal tipped with a single bristle. It is found in pine barren bogs from N. J. to Georgia.

\section{WILLOW-HERBS. EPILOBIUM.}

Low, or sometimes stout and even partly woody herbs, with opposite or alternate leaves, or both, but mostly opposite. Flowers solitary or in clusters. Sepals united to form a slender tube. Petals 4, notched or cleft at the tip, or sometimes merely rounded. Fruit a long slender pod filled with copiously down-tipped seeds that float on the breeze. (Onagraceae.) For related plants see Nos. 379, 380, and 445 . Of the Io species known in the area the four following may be distinguished thus:

Leaves sharply toothed

Flowers rose-purple, about $\mathrm{I}$ in. across $\ldots \ldots \ldots \ldots \ldots \ldots \ldots$.

......................... Great Willow-herb no. 435 Flowers pinkish-white, about $1 / 4$ in. across ................ Leaves without teeth

Leaf-veins distinct; leaf margins flat $\ldots \ldots \ldots \ldots \ldots \ldots \ldots$. 
Marsh Willow-herb no. 437 Leaf-veins inconspicuous; leaf margins rolled .............. Willow-herb no. 438 435. Great Willow-herb. Epilobium hirsutum. A stout coarse hairy, usually branched perennial, $2-4 \mathrm{ft}$. tall. Leaves toothed, mostly opposite, tapering both ends, about 2 in. long. Flowers mostly terminal, rose-purple, about I in. across. Pods about 2 in. long, and $1 / 10 \mathrm{in}$. in diameter. In waste places, about the seaports, rarely in the interior. JuncAugust. Native of Europe. Fig. 435 .

436. Willow-herb. Epilobium coloratum. Similar to No. 435 , but shorter and with flowers about $1 / 4$ the size. Pods about $I^{1} / 2$ in. long, the down brownish-red. In moist places, Maine and Ontario to So. Carolina, and westward. August. A related plant, E. adenocaulon, is very like E. coloratum, but has sticky hairs on the flower stalks and pods, and the down of the seeds is white. Also in moist places. Newfoundland to No. Carolina, and westward.

437. Marsi Willow-Herb. Epilobium palustre. Not usually branched and mostly about I $\mathrm{ft}$. tall. Leaves opposite, without teeth, broadest towards the middle, I-2 in. long, the margins flat, the veins prominent. Flowers about $1 / 4 \mathrm{in}$. wide, pinkish-white, mostly among the upper leaves. Pod about $\mathrm{I} / 2$ in. long. In bogs. Newfoundland to Long Island, N. Y., and westward, mostly in the north. August.

438. Willow-herb. Epilobium lineare. Not unlike No. 437, but the leaves practically parallel-margined, the veins inconspicuous, and the leaf margin distinctly rolled. In swamps. New Brunswick to Delaware and West Virginia, and westward. August. Fig. 438. A related plant, E. strictum, is white-hairy, has slightly toothed leaves, and grows in bogs from Quebec to Virginia, and westward.

439. Flowers white, rarely greenish or pinkish. (Nos. 440464.)

Leaves not compound or deeply cut, or divided ....... no. 443 Leaves deeply cut or divided, or compound 

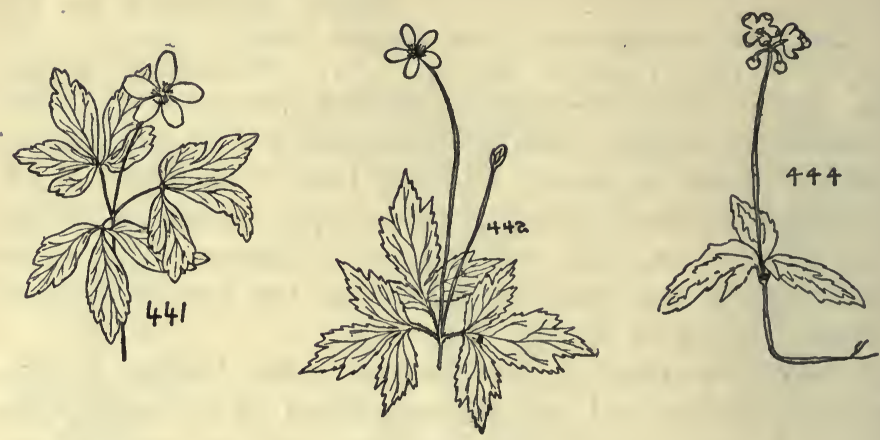

(The following three plants have no petals, but their sepals are petal-like and white. All belong to the Buttercup Family

Plants $4-8$ in. tall

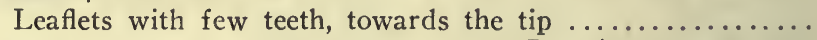
...................... Rue Anemone no. 440 Leaf divisions toothed throughout .... Wind-flower no. 44I

Plants I-3 ft. tall ............... Tall Anemone no. 442 440. Rue Anemone. Syndesmon thalictroides. (Anemonella thalictroides.) A low, smooth woods plant, mostly 6 in. high, soon withering when picked. Leaves partly basal, but some near the flowers, all compound, the leaflets on long threadlike stalks. Leaflets roundish, with a few (2-3) roundish teeth, towards the tip. Flowers white, or pinkish-white. Petal-like sepals 5-IO. May. New England to Florida, and westward. See No. 349.

44I. Wind-Flower. Anemone quinquefolia. A low woods plant with basal leaves and some near the flowers. Leaves deeply-divided, the segments toothed throughout. Basal leaves much longer stalked than the stem-leaves. Flowers white. Petal-like sepals 4-9. Nova Scotia to Georgia, and westward. Very common. May. Fig. 44I. See No. 349.

442. Tall Anemone. Anemone virginiana. A stout woods plant, hairy, I-3 ft. tall, with 3 -divided basal and stem leaves. Divisions of the leaf broad, coarsely toothed. Flower usually solitary, white or greenish-white, about I in. across. Petallike sepals 5. Nova Scotia to So. Carolina, and westward. 

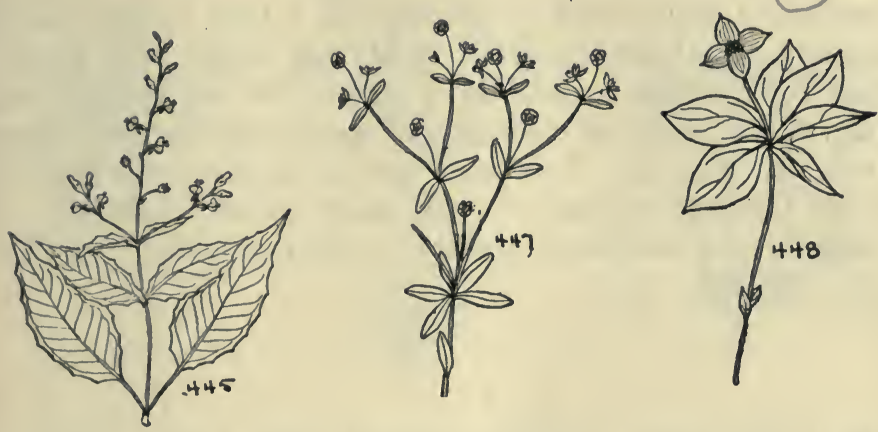

July. Fig. 442. There are several closely related species, separated by rather technical characters. Four others, at least, are known in the area, but they should be sought in the technical manuals. See No. 349.

443. Leaves not compound, or deeply cut, or divided. (Nos. 444-464.)

Leaves wholly without marginal teeth $\ldots \ldots \ldots \ldots$..... no. 446

Leaf margins distinctly toothed, but not deeply so

> Leaves white-spotted, largely basal; petals 5 .............

..................... Spotted Wintergreen no. 444

Leaves green, all on the stem; petals 2 ................ laccae.) One of the few white-variegated native plants. Leaves opposite, or in 3 's, short-stalked, lance-oval, I-3 in. long, white-mottled along the mid-rib, distantly toothed. Flower I-3, in a short-stalked cluster. Petals 5, white. Fruit a dry round pod. In dry woods. Maine and Ontario to Georgia, and westward. July. Fig. 444. The related Pipsissewa, $C$. umbcllata, has green leaves, broadest towards the tip and more regularly toothed. See also Nos. 5 I 3 and $5 \mathrm{I} 8$. 445. Enchanter's Nightshade. Circaca lutetiana. (Onagraceae.) An erect, but weak woodland plant, $\mathrm{I}-2 \mathrm{ft}$. tall. with opposite long-stalked leaves which are broadest at the base, and tapering to a point at the apex, 2-4 in. long, dis- 
tantly and finely toothed. Flowers in a long raceme, small, scarcely $1 / 8$ in. across, white. Petals and sepals 2. Fruit covered with minute, hooked, bristly hairs, the stalks recurving. July. Nova Scotia to Georgia and westward. Also in Europe and Asa. Fig. 445. A related species, C. alpina, is scarcely 8 in. tall, and grows in cool moist woods. Labrador to Georgia, and westward, mostly in the mountains. See Nos. $379,380,407,434$.

446. Leaves wholly without marginal teeth. (Nos. 447-464.) Leaves truly opposite, the joints often swollen ....... no. 453 Leaves in clusters of 3 , or more, or densely crowded Juice milky ................ Blooming Spurge no. 447 Juice not milky

Leaves clustered just beneath the flower

Bracts (simulating petals) $4 \ldots \ldots$ Bunch-berry no. 448 Petals usually $7 \ldots \ldots \ldots \ldots$.......... Star-flower no. 449 Leaves on other parts of the stem

Leaves in 4's; petals fringed or notched. Campion no. 450 Leaves in I2's or I8's; petals not fringed. Spurry no. $45 \mathrm{I}$ Leaves densely crowded, not over $1 / 4$ in. long

Sandwort no. 452

447. Blooming Spurge. Tithymalopsis corollata. (Euphorbia corollata.) (Euphorbiaceae.) An erect perennial, with milky juice, related to No. 4I9, the stem often spotted. Lower leaves often spotted. Lower leaves opposite, the upper in clusters of 4 to 6 , stalkless, oblong, rounded, but not round at the tip, about $I \frac{1}{2}$ in. long. Flowers white, in open loose clusters. In dry places. Ontario to Florida, and westward. June-July, Fig. 447. (See also Nos. 528-530.)

448. Bunch-Berry. Cornus canadensis. (Cornaceae.) A low, almost woody perennial of woods and thickets. Leaves clustered just below the flowers, not quite stalkless, oval, pointed both ends, about 2 in. long. Flower apparently solitary and white, from its 4 prominent bracts just beneath the small cluster of tiny greenish flowers. Fruit conspicuous, scarlet, berry-like. June. Newfoundland to Virginia, and westward, mostly in the mountains. Fig. 448. 

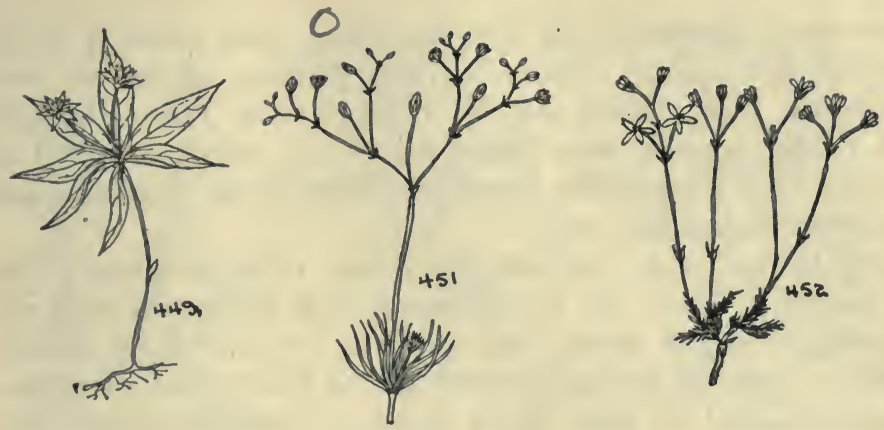

449. Star-flower. Trientalis americana. (Primulaceae.) A weak woods plant, 3-9 in. high, with a cluster of leaves at the summit of its unbranched stem, just below its I or 2 long-stalked flowers. Leaves essentially stalkless, lance-oblong, narrowed at both ends, faintly wavy-margined, about $2 \mathrm{~T} / 2$ in. long. Petals mostly 7 , very slightly united at the base. Labrador to Virginia, and westward. June. Fig. 449. See also No. 466.

450. Campion. Silene stellata. (Caryophyllaceae.) An erect perennial, covered with fine hairs. Leaves in 4's, essentially stalkless, narrowed both ends, about 3 in. long. Flowers about $3 / 4$ in. across, in a showy terminal cluster, white, the petals fringed. Pod not much inflated. In woods. Mass. to Georgia, and westward. July. There are several closely related species, one of them $S$. alba, has merely notched petals and opposite leaves. It ranges from Penn. and District of Columbia, westward. See No. 420.

451. SPURry, Spergula arvensis. (Alsinaceae.) A weedy plant of fields and waste places, usually much branched and sprawling. Leaves 12 or 18 at each joint, narrow, thread-like, about $11 / 2$ in. long. Flowers white, about $1 / 4$ in. wide, in a loose cluster. Petals 5, without notches or fringes. Nearly throughout North America. Native of Europe. July. Fig. 45I.

452. Sandwort. Arenaria caroliniana. (Alsinaceac.) A very deeply rooted, cushion-like perennial, usually growing in sand. Leaves tiny and needle-like, scarcely $1 / 4$ in. long, densely 
crowded. Flowers in an open lax cluster that stands $5^{-10}$ in. above the foliage. Petals narrow, pointed, white. In pine barrens. Long Island and N. J. to Florida. June. Fig. $45^{2}$. A related species, with longer leaves, $A$. stricta, is found on rocky cliffs, especially limestone. Ontario to Virginia, and westward. See No. 462.

453. Leaves truly opposite, the joints often swollen. (Nos. 454-464.) There are I I species in this group, all with opposite, toothless leaves, and more or less obviously swollen joints. They all belong in the Pink, or Chickweed, or related families, and all have white flowers (sometimes pinkish in the Bouncing Bet No. 460; and greenish in the Forked Chickweed No. 455). They may be distinguished thus:

A seabeach plant with fleshy leaves .. Seabeach Sandwort no. 454 Not growing in seabeaches; leaves not fleshy

Flowers greenish-white, stalkless, and mostly solitary at the leaf joints ................... Forked Chickweed no. 455

Flowers white, usually stalked and in clusters

Petals fringed or notched, often deeply so

Flowers about $\mathrm{I}$ in. wide ........ White Campion no. 456 Flowers $1 / 2$ in. wide or less; petals notched about $1 / 3$ their length ...................... Chickweed no. 457

Flowers about $1 / 4$ in. wide; petals notched almost or quite to the base

Leaves narrow, essentially stalkless .. Stitchwort no. 458 Leaves oval, distinctly stalked ...... Chickweed no. 459 Petals not fringed, if notched only very shallowly so

Flowers about $I$ in. broad ......... Bouncing Bet no. 460 Flowers less than $1 / 2$ in. broad

Leaves more or less oval

Flowers about $1 / 4$ in. wide; leaves $3 / 4$ in. long ......... Sandwort no. $46 \mathrm{I}$

Flowers about $1 / 8$ in. wide or less; leaves about $1 / 8$ in. long $\ldots \ldots \ldots \ldots \ldots \ldots \ldots \ldots$ Sandwort no. 462 Leaves narrow, linear

Flowers about $1 / 8$ in. wide; leaves scarcely $1 / 4$ in. long .. Pearlwort no. 463 Flowers about $1 / 3$ in. wide; leaves about $1 / 2$ in. long .. Mountain Sandwort no. 464 454. Seabeach Sandwort. Honkenya peploides. (Arenaria peploides.) (Alsinaceae.) A fleshy seabeach perennial with thick succulent leaves arranged in conspicuously 2-ranked pairs. Flowers white in a few-flowered but compact, mostly 

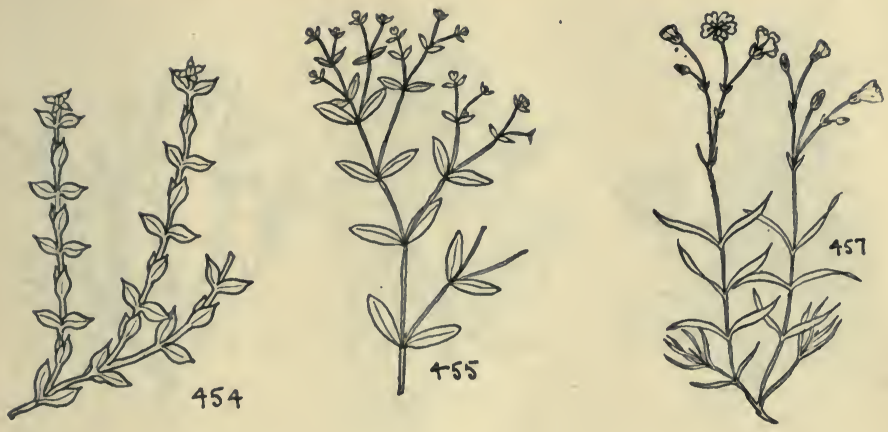

terminal, cluster. June. From Arctic America, along the coast, to N. J. and Virginia. Fig. 454.

455. Forked Chickweed. Anychia canadensis. (Corrigiolaccae.) A slender annual weed with repeatedly forking slender stems, usually about 9 in. high. Leaves about $1 / 2$ in. long, but much reduced in size towards the top of the plant. Flowers very small, greenish-white, stalkless and mostly solitary at the upper leaf joints. June-August. In dry places. Ontario to Georgia, and westward. Fig. 455. A related species, $A$. polygonoides, is shorter, has smaller hairy leaves, and is found in similar places from Maine to Florida, and westward.

456. White Campion. Lychnis alba. (Caryophyllaccae.) Related to No. 422 (see illustration), but with petals less deeply notched, and white, the pod much swollen in maturity. A weed of waste places. Nova Scotia and Ontario to N. Y. and Penn. July. See No. 420.

457. Chick weed. Cerastium arvense. (Alsinaceac.) A low weedy plant with opposite, stalkless, narrow leaves, which are pointed and about $3 / 4$ in. long. Flowers $1 / 2$ in. wide, in a loose open cluster, white, the 5 petals notched about $1 / 4$ their length. In dry places. Labrador to Georgia, and westward. May-July. Fig. 457. There are several other species, some European weeds, and all looking superficially much alike. One of the commonest is $C$. vulgatum, which is hairy and found throughout North America. 

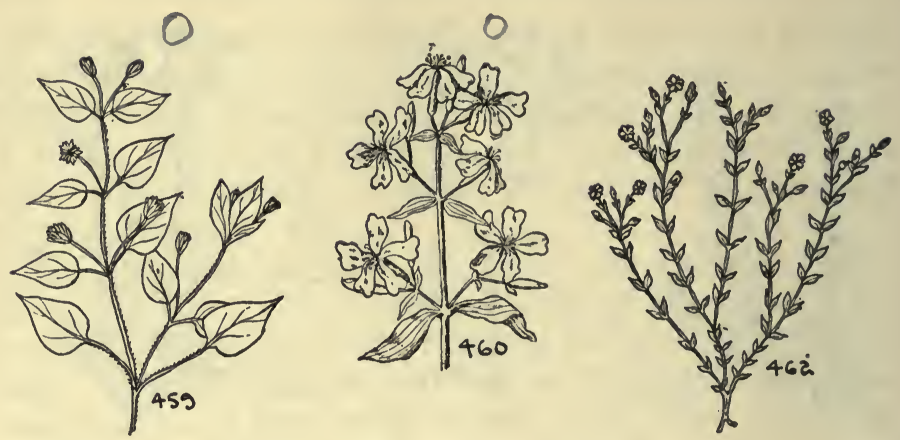

458. Stitchwort. Alsine longifolia. (Stellaria longifolia.) (Alsinaceae.) Superficially much like No. 457 , but the 5 petals so deeply cut as to appear to be I0, and the flower cluster more open and lax. In moist places. Newfoundland to Kentucky, and westward. June. A related species, $A$. graminca, has the petals not so deeply notched and flowers about $1 / 3$ in. wide. It grows in fields and waste places. Newfoundland and Ontario to Maryland.

459. Chickweed. Alsine media. (Stellaria media.) (Alsinaceae.) One of the commonest European weeds in America, found not only in waste places and cultivated land, but in woods. Almost prostrate. Leaves oval, stalked, the stalks and stem with a line of hairs along them. Flowers scarcely $1 / 4$ in. wide, white, the 5 petals deeply notched. March-October, Fig. 459.

46o. Bouncing Bet. Saponaria officinalis. (Caryophyllaceae.) A common European weed of waste places, growing about I ft. tall. Leaves $2-3$ in. long, oval, about $\mathrm{I}$ in. wide. Flowers white or pinkish, about $I$ in. across, several in a terminal cluster, the 5 petals very slightly notched. Fig. 460 . Nearly throughout North America. August. See No. 420. 46r. Sandwort. Moehringia lateriflora. (Arenaria lateriflora.) (Alsinaccae.) A low erect herb, usually not over 9 in. high. Leaves stalkless, oval-oblong, about $3 / 4$ in. long, both the margins and principal veins finely hairy. Flowers, white, few, in an open lax cluster, scarcely $1 / 2$ in. across, the 

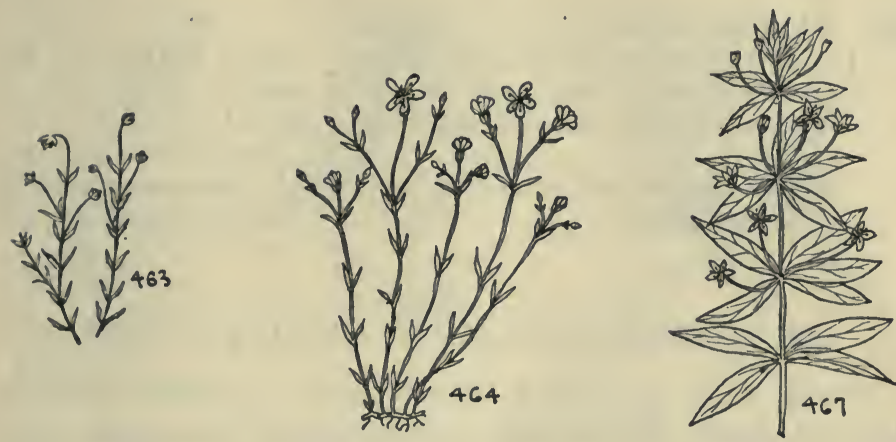

petals not notched. June. Moist places. Newfoundland to southern N. Y., and westward. Also in Europe.

462. Sandwort. Arenaria serpyllifolia. (Alsinaccae.) A much-branched, weak, hairy, annual weed, usually less than 6 in. high. Leaves opposite, oval, about $1 / 8$ in. long, broadest towards the stalkless base. Flowers $1 / 8$ in. wide, white, very numerous in a branched cluster, the petals not notched. MayAugust. Throughout North America, mostly in dry places. Fig. 462. See No. 452.

463. Pearlwort. Sagina procumbens. (Alsinarcae.) A densely matted low herb with linear needle-like leaves, scarcely $\mathrm{I} / 4$ in. long, Flowers white, usually I or 2 together on relatively 'long slender stalks, not over $1 / 8$ in. wide, the petals not notched, and sometimes wanting. Moist places. Newfoundland to Delaware, and westward. Native of Europe and Asia. May-September. Fig. 463. A native species, $S$. decumbens, with slightly larger petals is found from Mass. to Florida, and westward, and in drier places. 464. Mountain Sandwort. Arenaria grocnlandica. (Alsinaceae.) A low plant whose lax, open few-flowered flower cluster stands well above the sod-like matted foliage. Leaves needle shaped, $1 / 2$ in. long, actually opposite, but appearing densely crowded. Flowers, white, about $1 / 3$ in. across, the oblong petals not notched. Rocky places. Labrador and Greenland, south along the mountains to Virginia and No. Carolina. June-Sept. Fig. 464. 


\section{Flowers yellow. (Nos. 466-482).}

Leaves very small and densely crowded...False Heather no. 480 Leaves normal, if small, not densely crowded.

Sepals separate; leaves usually black dotted

........................ John's-Wort no. 472

Sepals united; leaves usually not dotted (sometimes slightly so in no. 468) ............... Primrose Family no. 466

\section{PRIMROSE FAMILY. PRIMULACEAE.}

Herbs, with opposite toothless leaves, or with leaves in fours. Flowers all yellow in the following, the sepals more or less united. Petals apparently separate, but actually united into a minute tube at the base. Fruit a single-celled capsule. These yellow flowered species are distinguished thus:

Leaves in fours $\ldots \ldots \ldots \ldots \ldots \ldots \ldots \ldots$. Crosswort no. 467

Leaves opposite

Plant prostrate; leaves roundish ........... Moneywort no. 468

Plants more or less erect; leaves pointed

Flowers in terminal pointed clusters..Swamp Candles no. 469

Flowers solitary, from among the upper leaves, or in clusters; not terminal

Flowers about $3 / 4$ in. wide, few

..................... Fringed Loosestrife no. 470

Flowers about $1 / 4$ in. wide, in dense, finger-shaped clusters Tufted Loosestrife no. $47 \mathrm{I}$

For related plants of this family see nos. 449, 527, 649, 691, 801, and 947 .

467. Crosswort Lysimachia quadrifolia. A common woods or thicket plant, with lance-shaped almost stalkless leaves conspicuously in fours. Flowers $1 / 3$ in. wide, yellow, solitary on slender stalks arising at the leaf-joints. Fruit a rounded capsule. New Brunswick to Georgia, and westward. July. Fig. 467.

468. Moneywort, Lysimachia Nummularia. A vine-like perennial, usually prostrate, with opposite, stalked, roundish leaves and one or two yellow flowers from each leaf insertion. Leaves about $3 / 4$ in. wide, on stalks about as long as the leaves, or a little longer. Moist places. Newfoundland to Virginia, and westward. Native of Europe, but often appearing wild. July. Fig. 468. 

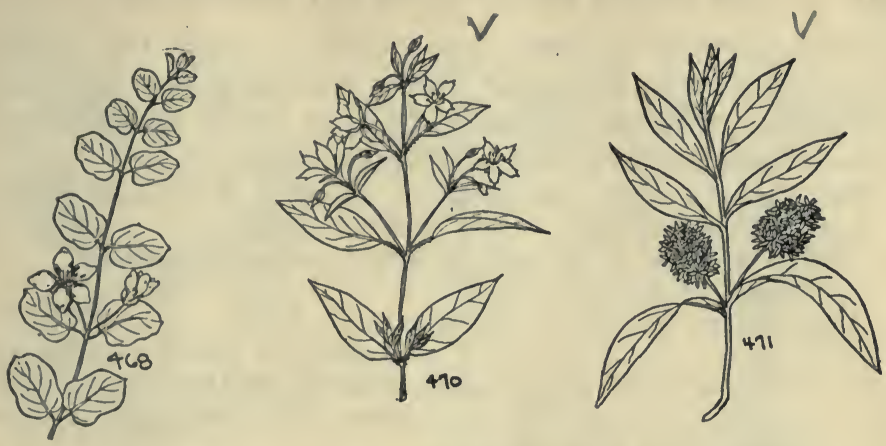

469. Swamp Candles. Lysimachia terrestris. An erect herb of moist places, not over $2 \mathrm{ft}$. tall. Leaves stalkless, lanceshaped, about 2 in. long, pointed both ends. Flowers, yellow, purple streaked, or dotted, often in a pointed terminal cluster, the individual flowers often replaced by reddish cigarshaped bulblets. Newfoundland to Georgia, and westward, August.

470. Fringed Loosestrife. Steironema ciliatum. An erect herb 2-3 ft. tall. Leaves decidedly stalked, the stalks minutely hairy. Leaf blade oval, pointed at the tip, rounded at the base, about 3 in. long. Flowers yellow, solitary at the leaf joints, the petals tipped with a minute prickle. Moist places. Nova Scotia to Georgia, and westward. July. Fig. 470. A related species, $S$. lanceolatum, differs in having lanceshaped, almost stalkless leaves. It is found in similar situations. Newfoundland to Georgia, and westward.

471. Tufted Loosestrife. Naumburgia thyrsiflora. An erect usually unbranched herb I-2 ft. tall. Leaves opposite, almost stalkless, pointed both ends, about 3 in. long. Flowers in a compact, finger-shaped cluster, yellow, often black-spotted, usually not over $1 / 4$ in. wide. Swamps and bogs. Nova Scotia to N. Y., Penn. and westward. June. Fig. 47I.

\section{ST. JOHN'S-WORT. HYPERICUM.}

Low or tallish herbs with opposite leaves, which are always dotted with black or brownish-red, minute dots. 
Flowers mostly in loose clusters, the 5 sepals not united. (Hypericaccac.) There are many species, a few of which are shrubs, and some of the herbs have almost woody stems. Those included here may be distinguished:

Tall, almost shrubby, 2-6 ft. high.... Giant St. John's-wort no. 473 Low, scarcely shrubby, mostly under $2 \mathrm{ft}$. high

Flowers about $1 / 2$ in. wide or more; stamens numerous.

Leaves of an oblong type

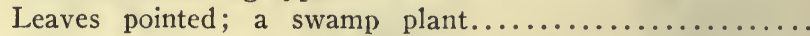
. Creeping St. John's-wort no. 474 Leaves blunt at the tip; a plant of fields or waste places ................ Common St. John's-wort no. 475 Leaves of an oval type

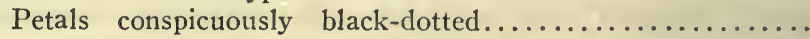
................... Spotted St. John's-wort 110. 476

Petals not dotted .......... Pale St. John's-wort no. 477 Flowers $1 / 4$ in. wide or less; stamens $5-12$

Leaves oval, about $3 / 4$ in. long.. Dwarf St. John's-wort no. 478 Leaves oblong or linear, usually less than $3 / 4$ in. long .......

For related species see nos. $4^{\mathrm{I} 3} 3$ and " 483 .

Canadian St. John's-wort no. 479 473. Giant St. John's-wort. Hypericum Ascyron. A stout, almost woody perennial herb from 2-6 ft. tall growing along stream banks, and in other wet places. Leaves opposite, essentially stalkless, pointed at the tip, and broadest towards the base, $2 \frac{1}{2}-4$ in. long. Flowers $\mathrm{I}-2$ in. across, the 5 petals oblong. Quebec and Vermont to N. J. and Penn., thence westward. July. Fig. 473.

474. Creeping St. John's-wort. Hypericum adpressum. An erect, scarcely branched herb, I-2 ft. high, arising from a creeping spongy base. Leaves opposite, stalkless, oblong, I$I / 2$ in. long. Flowers about $3 / 4$ in. wide, in a loose leafy cluster. Moist places. Mass. to Georgia, and Louisiana, along the coast, and from Missouri and Arkansas in the interior. July.

475. Common St. John's-wort. Hypericum perforatum. A weed of fields and waste places throughout North America. Somewhat woody, usually much branched, not over $2 \mathrm{ft}$. tall. Foliage and flowers very like No. 474, but the petals conspicuously black dotted. June-Sept. Native of Eurasia. Fig. 475. 

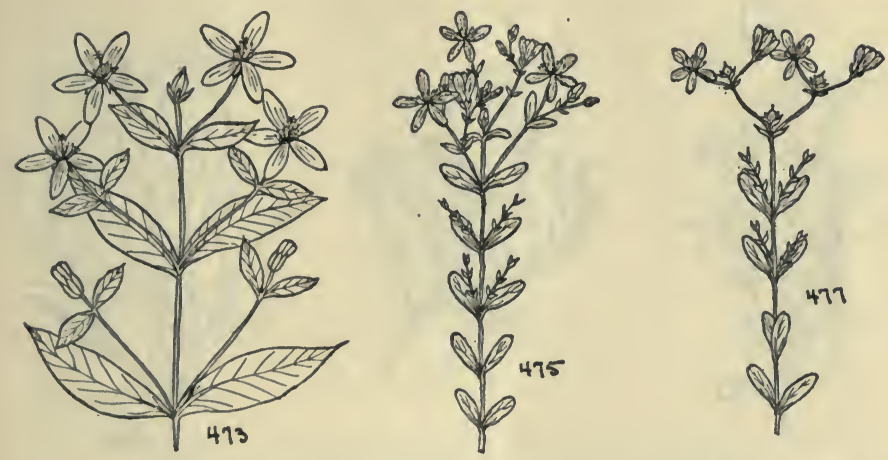

476. Spotted St. John's-wort. Hypericum punctatum. Very like No. 475 , but the leaves of an oval type, I-3 in. long. The leaves and the petals conspicuously black-dotted. In moist places. Quebec and Ontario to Florida, and westward. June-September.

477. Pale St. John's-wort. Hypericum ellipticum. Usually not over 18 in. high, with a slightly 4 -angled stem. Leaves oval, stalkless, about I in. long. Flowers yellow, not spotted, about $1 / 2$ in. wide, in a terminal cluster. Swamps and wet places. Nova Scotia to Maryland, and westward. July. Fig. 477.

478. Divarf St. Jonn's-wort. Hypericum mutilum. A slender much branched annual, with slightly 4-angled stems, not over 18 in. tall. Leaves oval, stalkless, almost stem-clasping, obviously 5 -veined, about $3 / 4$ in. long. Flowers few, about $1 / 5$ in. wide, orange-yellow, in a loose open cluster. Moist places. Nova Scotia to Florida, and westward. August.

479. Canadian St. John's-wort. Hypericum canadense. A slender, usually much branched herb, 8-18 in. high. Leaves of an oblong linear type, stalkless, about $\mathrm{I}$ in. long. Flowers about $1 / 4$ in. wide, in an open loose, terminal cluster. In moist places. Newfoundland to Georgia, and westward. August. Fig. 479. A closely related species, $H$. boreale, differs in having numerous miniature leaves scattered among the flower cluster. It grows in wet places. Newfoundland to Penn. and westward to Indiana. 

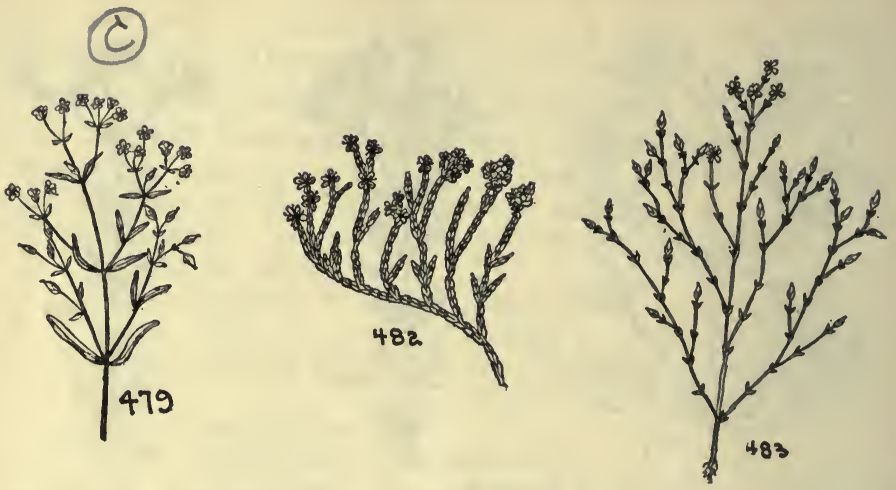

\section{FALSE HEATHER, HUDSONIA.}

Low, almost woody, herbs of dry sandy places, with tiny and densely crowded leaves, needle-like in one species, and tightly compressed and scale-like in the other. Flowers small, yellow, usually fairly numerous, but individual ones terminating tiny flower stalks, or almost stalkless. Petals 5, spreading. (Cistaceae.) Related plants will be found at Nos. 29I and 334 .

Flowers obviously slender stalked; leaves needle like.

48i. False Heather or Poverty Grass. Hudsonia ericoides. A bushy branched low, almost woody perennial, green and softly haired throughout. Leaves crowded, but separate, needle-like, scarcely $1 / 4$ in. long. Flowers about $1 / 4$ in. wide, the yellow petals pointed. In dry sand, especially under pine or oak trees. Newfoundland to Virginia, mostly along the coast. June.

Flowers almost stalkless; leaves scale like; plant ashy grey.

482. False Heather. Hudsonia tomentosa. Similar in habit to No. 48I, but the scale-like leaves tightly pressed against the twigs, the whole plant ashy grey. Flowers essentially stalkless, yellow, the petals rounded. Sand dunes and other sandy places, mostly in the open. New Brunswick to Virginia, and westward. June. Fig. 482. 

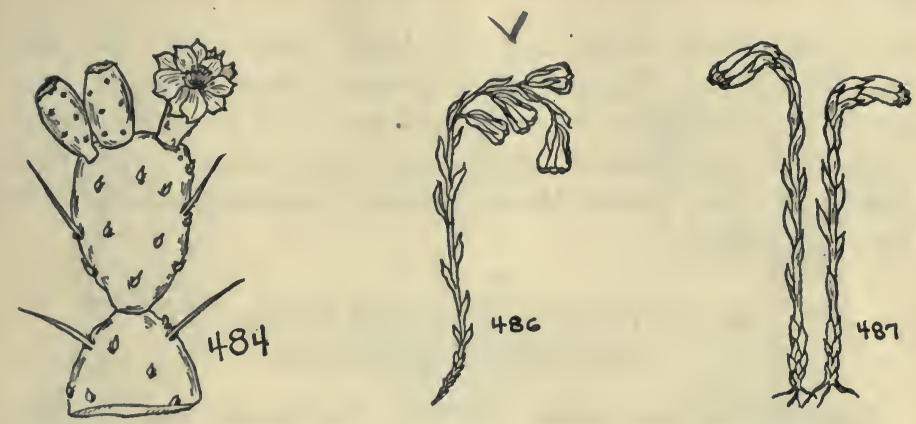

483. ORANGE-GRASS. SAROTHRA.

A much branched essentially leafless annual weed, the obviously opposite leaves reduced to tiny scales. Flowers small, yellow, solitary in the points of the scale-like leaves. (Hypericaceae.) Related plants are Nos. 4I3, 472-479. The only species is:

OrANGE-Grass. Sarothra gentianoides. (Hypericum gentianoides.) Erect and freely branching, not usually over 8 in. tall, sometimes 15 in., wiry. Leaves reduced to tiny, sharppointed scales, scarcely $1 / 10$ in. wide. Flowers yellow, about $1 / 10$ in. wide, closing at night, or on cloudy days. Sandy places. Maine to Florida, and westward. June-October. Fig. 483 .

\section{PRICKLY PEAR. OPUNTIA.}

The only eastern representative of the numerous Cactus Family. Leaves mostly none, the flat joint-like green branches, serving as leaves, and more or less irregularly dotted with long spines. Flowers borne directly on the edges of the joints, bright yellow in our species, composed of numerous petals. Fruit fleshy, edible if the spines are removed, but causing near strangulation if they are not. (Cactaceae.) Our only species is:

Prickly Pear. Opuntia Opuntia. (Opuntia vulgaris.) Prostrate and rooting at the joints in mature specimens. Joints 
oval or oblong oval, $2-5$ in. long, about half as wide and $1 / 2$ in. thick. Spines, when present, stout, straight, ashygrey, $1 / 2-I$ in. long. Flowers solitary, $2-3$ in. wide, bright yellow. Fruit inverted pear-shape, red, about $\mathrm{I}$ in. long. Sandy or rocky places. Mass. to Penn., Kentucky and Florida. July. Fig. 484.

\section{INDIAN PIPE AND PINE-SAP. (MONOTROPACEAE.)}

Curious leafless plants, the scale like bracts and branches never green, usually white or pinkish white. Flowers solitary or in small clusters, the 5 petals (in our species) separate. Fruit a dry pod.

Flowers clustered, pinkish or yellowish, not nodding.

486. Pine-SAP. Hypopitys americana. (Monotropa Hypopitys.) An erect leafless, yellowish white herb, not over I ft. tall, the stems sparingly beset with narrow scale-like bracts, about $1 / 3$ in. long. Flowers few, in a terminal cluster, yellowish or pinkish, about $3 / 4$ in. long, the petals minutely hairy. Grows on decayed wood or humus in rich woods. Ontario to No. Carolina, mostly in the mountains. July. Fig. 486. A closely related species, $H$. lanuginosa, differs in having longer hairs on the petals and in being a deeper reddish color. In similar situations. Newfoundland to Florida, westward to Indiana and Tenn.

Flowers solitary, white, nodding.

487. Indian PiPe. Monotropa uniflora. A ghostly white woodland plant, living on dead wood or humus, never green, about 8 in. tall. Leaves none, the white scales on the stem about $3 / 4$ in. long. Flower white, solitary, nodding, oblong bell-shaped, about $3 / 4$ in. long, becoming erect in fruit. Anticosti to Florida, and westward. July. Fig. 487.

488. PITCHER PLANT AND SUNDEW. $S A R R A C E N I A C E A E$ AND DROSERACEAE.)

Insect catching and digesting, bog, plants of strange habit, and unusual food requirements. The Pitcher-plant has a 

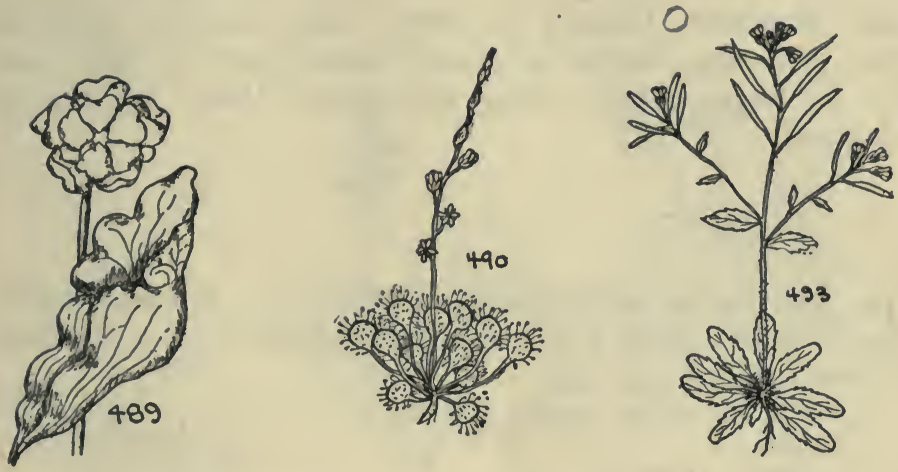

rosette of basal leaves transformed into hollow bent-pitcher shaped structures, beset on the inside with downward pointing hairs. Its solitary reddish or tawny-yellow flower is at the end of a single stalk, and is apparently inverted. The Sundews are pinkish, low, plants covered with glistening sticky hairs, and have white flowers in small terminal clusters. Our insect catching plants may be distinguished:

Leaves hollow, shaped like a bent pitcher; flower solitary, terminal, red or yellowish .............. Pitcher Plant no. 489

Leaves not hollow, covered with glistening sticky hairs; flowers in clusters, white

Leaves roundish $\ldots \ldots \ldots \ldots \ldots \ldots \ldots$............... Sundew no. 490 Leaves thread-like $\ldots \ldots \ldots \ldots \ldots \ldots \ldots \ldots$. Sundew no. 49I 489. Pitcher Plant. Sarracenia purpurea. A bog plant with a rosette of hollow leaves, shaped like bent pitchers. Pitchers purple veined, 3-6 in. long, about $1 / 4$ as wide, fringed on the inside with downward pointing hairs, and usually partly filled with water and insect remains. Flower solitary, nodding, reddish-purple, or yellowish, its stalk $\mathrm{I}-2 \mathrm{ft}$. tall. Labrador to Florida, and westward. June. Fig. 489.

490. Sundew. Droscra rotundifolia. A slender, nearly always reddish plant, glistening in the sun, because of its covering of sticky hairs. Leaves all basal, round above, narrowed into slender stalks. Flowers white, in a slender terminal raceme. In bogs, or wet sand. Newfoundland to Florida, and westward. July. Fig. 490. There are many leaf forms, some clubshaped, but the typical form always has round leaves. 
I64 A GUIDE TO THE WILD FLOWERS

491. Sundew. Drosera filiformis. Very like No. 490, but the glistening leaves long and thread-like. In wet sand, or in bogs, mostly along the coast. Mass. to Florida. August.

492. Leaves exclusively basal, or with only I or 2 stem leaves, rarely more. (Nos. 524 and 525 sometimes have a few stem leaves.) Nos. 493-525.

Petals, or colored sepals, 5 or more .............. no. 496

Petals 4

Leaves undivided

Pods long and narrow .......... Mouse-ear Cresss no. 493

Pods oval-pointed .............. Whitlow-grass no. 494

Leaves cut into pointed segments .... Shepherd's-purse no. 495

-493. Mouse-ear Cress. Arabidopsis Thaliana. (Sisymbrium Thalianum.) (Cruciferae.) An annual European weed 3-IO in. high, with a rosette of basal leaves and a few smaller ones on the stem. Leaves lance-oval, I-2 in. long, faintly toothed. Flowers in an open lax cluster, scarcely $1 / 8$ in. wide, white. Pods about $3 / 4$ in. long, almost thread-like. Dry places. Mass., and southern Ontario to Georgia, and westward. May. Fig. 493. See No. 383 .

494. Whitlow-Grass. Draba verna. (Cruciferae.) Resembling No. 493, but smaller, and with no leaves on the stem. Pods oval-pointed, scarcely $1 / 3$ in. long. April. Native of Europe. In dry places, and fields. Mass. to Georgia, and westward. A related native species, $D$. caroliniana, differs in having longer pods that are not oval. It is found in dry sandy places. Ontario and Mass. to Georgia, and westward. See No. 383 .

495. Shepherd's-Purse. Bursa Bursa-pastoris. (Capsella Bursa-pastoris.) (Cruciferae.) One of the commonest weeds in the world, native of Europe. Leaves nearly all in a basal rosette, $2-5$ in. long, cut into pointed segments. Flowers in, a terminal raceme, white, scarcely, $1 / 8$ in. wide, the triangular pod notched. March-November. Fig. 495. (See No. 383.) 

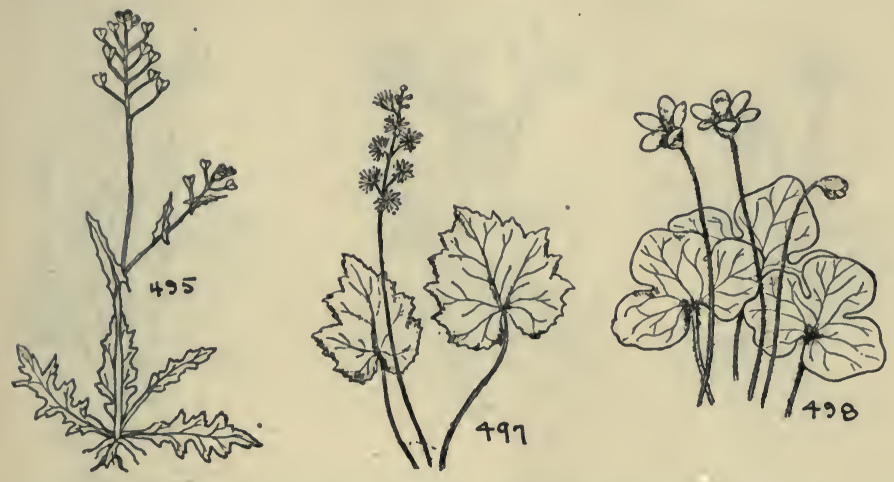

496. Petals, or colored sepals, 5 or more. (Nos. 497-525.)

Leaves not compound, or divided, or lobed, or cut..... no. 5II

Leaves compound, or divided, or lobed, or cut

Flowering stalks (or the plant) 1o in. high or more ... no. 507

Flowering stalks (or the plant) $7 \mathrm{in.}$ high or less

Leaves compound and with 3 leaflets $\ldots \ldots \ldots \ldots$ no. 502

Leaves merely lobed or cut, not compound, and with 3 leaflets

Flowers in terminal racemes ..... Foam-flower no. 497 Flower solitary at the end of the stalk

Petals none; petal-like sepals 7-12 .. Hepatica no. 498 Petals and sepals present

Flowers $3 / 4$ in. wide or less ...... Gold-thread no. 499 Flowers $I$ in. wide or more

Sepals 2 ; leaves $5-9$-lobed ...... Bloodroot no. 500

Sepals 4 ; leaves 2 -lobed ....... Twin-leaf no. 501

497. Fonm-Flower. Tiarella cordifolia. (Saxifragaceae.) A hairy woods plants, mostly in mountainous regions, and not over 8 in. high. Leaves basal, heart-shaped at the base, 3-7 lobed, toothed, $2-4$ in. long, long-stalked. Flowers white, in a terminal raceme, not over $1 / 3$ in. wide. Fruit a dry pod. Nova Scotia and Ontario to Georgia, and westward to Indiana and Michigan. May. Fig. 497. For other plants of this family see Nos. 258, 509, $5^{10}, 5^{12}$, and 522. 498. Hepatica. Hepatica Hepatica. (Hepatica triloba.) (Ranunculaccac.) A hairy woods plant with kidney-shaped, 3lobed, half evergreen leaves that are about 2 in. wide, and 

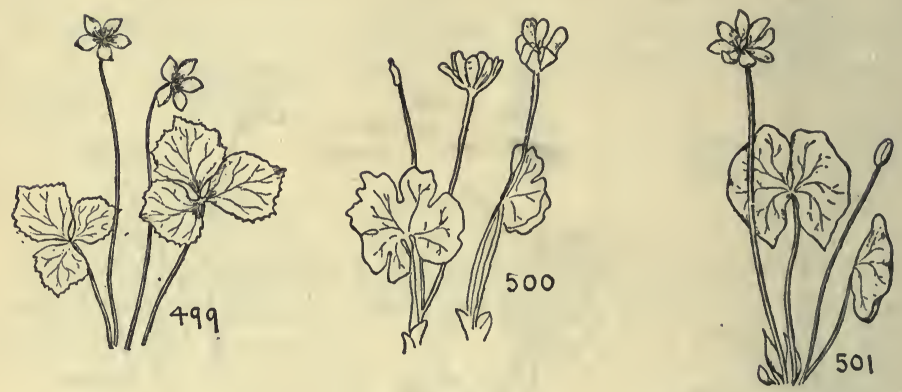

long stalked. Flower solitary at the end of the stalk, blue or purple, rarely white, from its colored sepals. Petals none. Sepals 6-8, and surrounded by 3 sepal-like bracts. AprilMay. Nova Scotia to Florida, and westward. Fig. 498. There are many forms, some with pointed leaf-segments. See No. 349.

499. Gold-thread. Coptis trifolia. (Ranunculaceae.) Scarcely 6 in. high, usually lower. Leaves deeply 3-divided, evergreen, the segments toothed and wedge-shaped: Flower white, solitary, at the end of the stalk, about $3 / 4 \mathrm{in}$. wide or less. Fruit dry, beaked and stalked. In moist woods or bogs. Newfoundland to Tenn., and westward. June. Fig. 499. The plant takes its name from its bright yellow roots. See No. 349.

500. Bloodroot. Sanguinaria.canadensis. (Papaveraceae.) A bluish green herb of rich woods, flowering before or with the unfolding of the leaves. Leaves 5-9 lobed, prominently veined, 5-8 in. wide, the stalks slightly longer. Flower solitary, white, with 2 soon-falling sepals, and 8-I 2 petals. Juice red. Nova Scotia to Florida, and westward. May. Fig. 500. See Nos. 333 and 404.

501. Twin-Leaf. Jeffersonia diphylla. (Berberidaceae.) Not 2-leaved, but with the long-stalked leaves deeply 2-divided, and bluish beneath. Flower solitary at the end of the stalk, white, about I in. wide, with 4 petal-like sepals, and 8 petals. Fruit leathery, dry. In wonds. Ontario to Tenn., and west- 


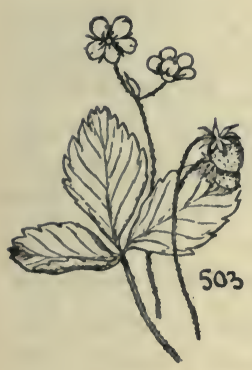

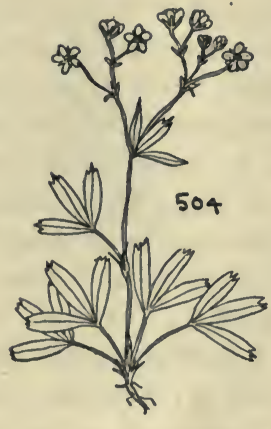

ward. Rare or unknown near the coast. May. Fig. 50I. (See also Nos. 344 and 508.)

502. Leaves compound and with 3 leaflets. (No. 499 should not be sought here.)

Leaflets toothed all around ......... Wild Strawberry no. 503

Leaflets notched at the tip, but without marginal teeth.

Leaflets wedge shaped, sharply notched at the tip .......... Three-toothed Cinquefoil no. 504 Leaflets broadly triangular, shallowly notched at the tip.

Flowers rose-purple, $3-8$ in a cluster $\ldots \ldots \ldots \ldots \ldots$.

Flowers white or pink, veined with deeper pink, solitary on the stalk ............. White Wood-sorrel no. 506 503. Wild Strawberry. Fragaria virginiana. (Rosaceae.) A low prostrate herb, creeping by runners. Leaves compound, the 3 leaflets short-stalked, toothed, slightly inequilateral, especially the side ones, about $I_{1} / 2$ in. long. Flower stalk about the.same length as the leaf stalks or shorter. Flowers white, about $3 / 4$ in. wide, in an open loose cluster. Fruit the familiar wild strawberry. In dry places, Newfoundland to Florida, and westward. May. Fig. 503. There are several related species, one of which $F$. americana has the flower stalks exceeding the leaves. It has nearly a similar range, but is found in rocky woods. See No. 359 . 
504. Three-toothed Cinguefoil. Sibbaldiopsis tridentata. (Potentilla tridentata.) An almost woody, prostrate plant of rocky summits, scarcely over 6 in. high. Leaves all basal, compound, with 3 wedge-shaped leaflets that are conspicuously 3 (rarely 2 or 5 ) notched at the tip. Flowers white, about $1 / 2$ in. wide, in an open terminal cluster. Fruit dry. Greenland to the higher southern Alleghanies, and westward. July. Fig. 504. Related plants are Nos. 36I-367.

505. ViOlet WoOD-SORRel. Ionoxalis violacea. (Oxalis violacea.) (Oxalidaceae.) A delicate woods plant with compound, long-stalked leaves, and 3 triangular, shallowly notched leaflets, without teeth. Flowers in a sparse cluster, rose-purple, rarely whitish, about $3 / 4$ in. wide, with 5 petals and sepals. Fruit a minutely warty pod. Mass. to Florida, and westward. May. Fig. 505. Related plants are Nos. 37 I-373.

506. White Wood-SOrrel. Oxalis Acetosella. (Oxalidaceae.) Resembling No. 505, but with white or pink solitary flowers that are veined deep pink. It also bears inconspicuous flowers near the ground that never open. In cold moist woods. Nova Scotia southward, mostly in the.mountains, to No. Carolina ; north shore of Lake Superior. Also in Europe, Asia and northern Africa. June. See also Nos. 37 I-373.

507. Flowering stalks (or the plant) Io in. high or more. Flower solitary, 2 in. wide; leaves deeply divided ........... ...................................... Apple no. 508 Flowers less than $1 / 2$ in. wide, in clusters; leaves shallowly lobed Flowers greenish, petals very small ...... Alum-root no. 509 Flowers white, petals conspicuously fringed

508. Mà Apple. Pöophyllum peltatum. (Berberidaceae.) A poisonous-rooted, smooth perennial, with large deeply divided leaves, and a solitary, stalked white flower 2 in. wide. Leaves nearly I ft. in diameter, basal, or I or 2 on the stem, roundish in outline, and 5-9 lobed. Petals 6-9, waxy. Fruit edible, fleshy, yellow, about 2 in. long. In woods. Quebec and Ontario to Florida, and westward. May. Fig. 508, See also Nos. 344 and 501 . 

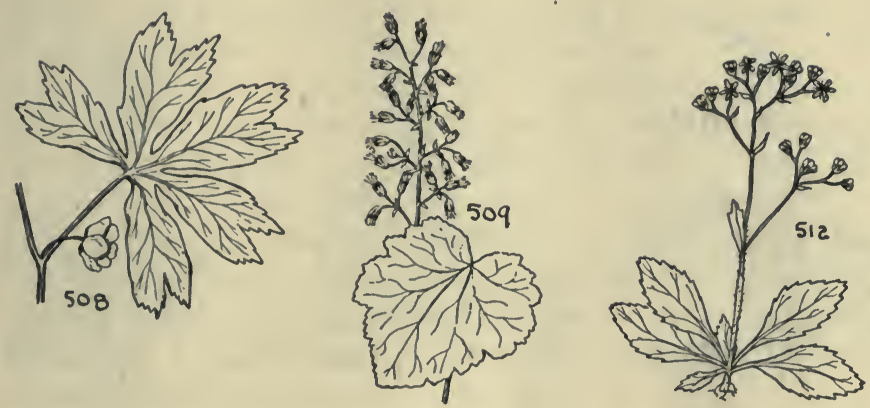

509. Alum-RoOT. Heuchera americana. (Saxifragaceae.) A hairy woods plant with basal long-stalked leaves and greenish flowers. Leaves shallowly $7-9$ lobed, roundish in outline, deeply heart shaped at the base, about 3 in. wide. Flowers in a terminal raceme, that is $\mathrm{I}-2 \mathrm{ft}$. high; petals minute, anthers orange. Ontario to Alabama, and westward. Fig. 509. June. For other plants of the family see Nos. 258, 497, 5 IO. 512 and 522 .

510. Bishop's-cap. Mitella diphylla. (Saxifragaceae.) Somewhat resembling No. 509, but with 2 leaves on the stem, and with whitish flowers. In rich woods. Quebec to No. Carolina, and westward. Early May. A close relative, usually without stem leaves, $M . m u d a$, is smaller, more slender, and is confined to cold moist woods and bogs. Labrador and Newfoundland to the mountains of Penn. and northwestward.

5II. Leaves not compound, or divided, or lobed, or cut. (Nos. 512-525.)

Flowers not white ........................... no. 52 I

Flowers white (sometimes veined with other colors)

Flower solitary, rarely 2 to a stalk ............. no. 517 Flowers in terminal clusters.

Flowers about $1 / 4$ in. wide ....... Early Saxifrage no. 512 Flowers about $1 / 2$ in. wide, the petals partly united ....... 

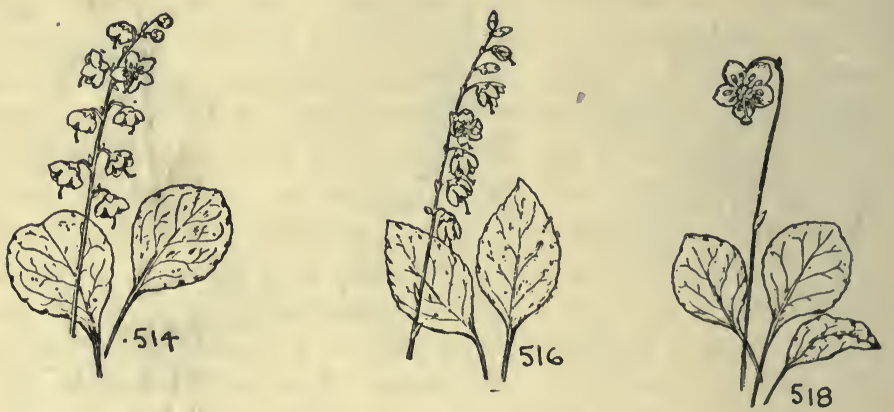

512. Early Saxifrage. Micranthes virginiensis. (Saxifraga virginiensis.) (Saxifragaccae.) A slender, sticky, herb of rocky places, not usually over 6 in. high. Leaves basal, oval or broadest towards the tip, bluntly toothed, I-3 in. long. Flowers white, in a loose open cluster, about $1 / 4$ in. wide, the petals separate. New Brunswick to Georgia, and westward. April. Fig. 512. See also No. 522.

\section{SHIN-LEAF. PYROLA.}

Perennial herbs with thick, dark green, half evergreen leaves. Flowers, nodding, often fragrant, in a terminal raceme. Petals 5, partly united below, slightly concave, surrounded by 5 minute sepals. Fruit a dry pod. (Pyrolaceae.) For related plants see Nos. 444 and 518. The shin-leafs are distinguished thus:

Flower cluster not I-sided.

Leaves shining; plant $7-18$ in. tall ........ Shin-leaf no. $5 \mathrm{I} 4$

Leaves dull; plant 5-10 in. tall ........... Shin-leaf no. 5I5

Flower cluster decidedly I-sided ............. Shin-leaf no. 516 5I4. Shin-Leaf. Pyrola americana. A smooth plant of rich woods with basal leaves that are stalked, roundish in outline, faintly toothed and $\mathrm{I} / 2-4$ in. long. Flower-stalk $7-\mathrm{I} 8 \mathrm{in}$. tall, with 6-20 flowers. Nova Scotia to Georgia, and westward. June. Fig. 514. A related species, $P$. chlorantha is 
smaller, has greenish-white flowers, and is found from Labrador to District of Columbia, and westward.

5I5. SHin-LEAf. Pyrola elliptica. Resembling No. 5I4, but with dull leaves, a flower stalk usually about 8 in. tall, and the flowers slightly greenish-white. In rich woods, Nova Scotia to D. C. and westward. July.

516. Shin-leaf. Pyrola secunda. Not over 8 in. tall, usually less. Leaves oval, pointed both ends, about $I \frac{1}{2}$ in. long, distinctly but shallowly toothed. Flowers white or greenishwhite in a I-sided cluster. Rich woods. Labrador to District of Columbia, and westward. Fig. 516.

517. Flower solitary, rarely 2 to a stalk.

Woods plants; leaves faintly, but distinctly toothed

Leaves rounded or pointed at the base $\ldots \ldots \ldots \ldots \ldots \ldots \ldots$.

Leaves heart-shaped at the base .......... Dewdrop no. 519

Swamp or bog plant; leaves toothless

....................... Grass-of-Parnassus no. 520

518. One-Flowered Wintergreen. Moneses uniflora. (Pyrolaceae.) Resembling Nos. 514-516, but usually not over 4 in. tall, and with a single white, sometimes pinkish, nodding, and often fragrant flower. In rich woods, especially under evergreens. Labrador to Penn., and westward, mostly in the mountains. July. Fig. 518.

519. Dewdrop. Dalibarda repens. (Rosaceae.) A low prostrate hairy perennial, with mostly basal leaves, but one or two on the short stem. Leaves shallowly toothed, roundish, deeply heart-shaped at the base, about $I^{1} / 2$ in. wide. Flower solitary, white, its 5 petals rounded. Fruit dry. In rich woods. Nova Scotia to No. Carolina, and westward. July-August. Fig. 519. See No. 359 for general characters of the Rose Family.

520. Grass-of-Parnassus. Parnassia caroliniana. (Parnassiaceae.) A smooth bog or swamp plant with basal stalked leaves, and a single stalkless one on the stem. Leaves broadly 

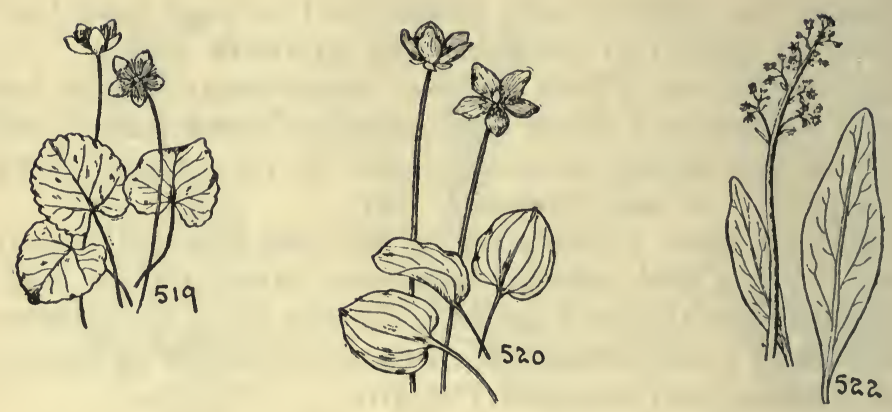

oval or roundish, without teeth, about $I \frac{I}{2}$ in. long. Flower white, about I in. wide, the 5 petals more or less pointed. Fruit dry. New Brunswick to Virginia, and westward. JulyAugust. Fig. 520.

521. Flowers not white.

Flowers greenish; leaves wavy-margined or toothed .........

Flowers not greenish; leaves toothless.

.Swamp Saxifrage no. 522

Salt marsh plant; flowers small, lavender purple

Dry land plants; flowers pink.

Sea Lavender no. 523

Flower about $I$ in. wide ..............Wild Pink no. 524

Flower about $1 / 4$ in. wide ........ Sleepy Catchfly no. 525 522. Swamp Saxifrage. Micranthes pennsylvanica. (Saxifraga pennsylvanica.) (Saxifragaceae.) A marsh or swamp plant with basal leaves and a terminal flower cluster, $\mathrm{I}-2 \mathrm{I} / 2$ ft. tall. Leaves oblong, or oblong-oval, essentially stalkless, wavy-margined, sticky-hairy, 5-8 in. long, about $I^{1} / 2$ in. wide. Flowers minute, in a branched cluster, greenish. Maine and Ontario to Virginia, and westward. May. Fig. 522. See No. 5 I2.

523. Sea Lavender. Limonium carolinianum. (Plumbaginaceae.) A salt marsh plant with a thick woody base and a rosette of leathery basal leaves, which are broadest towards the tip and taper towards the base. Leaves 5-8 in. long, fine pointed at the tip. Flowers minute in a large, branching 

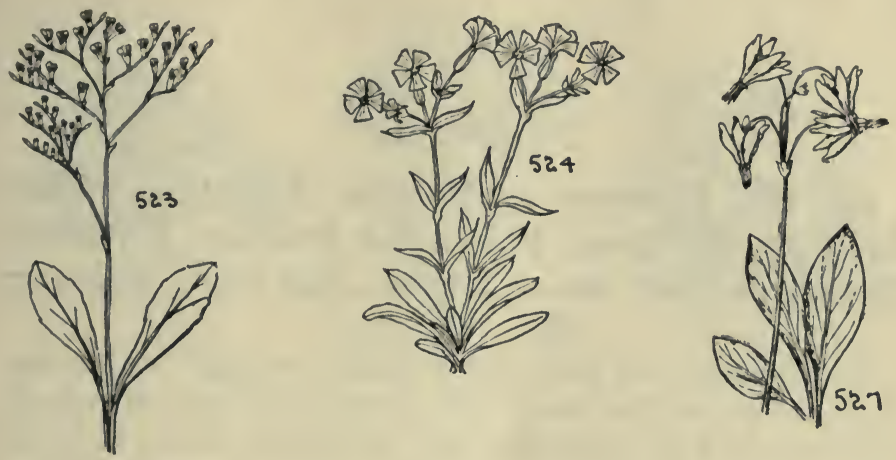

cluster, often 18 in. high. Petals 5 , very small, lavenderpurple. In salt meadows. Labrador to Florida and Texas. August. Fig. 523.

524. Wild Pink. Silene caroliniana. (Caryophyllaceac.) A plant of dry sandy places, sticky-hairy in all its parts. Leaves mostly basal, but a few on the stem, toothless, about 3 in. long, usually broadest towards the tip. Flowers pink, almost I in. wide, in a terminal cluster. Petals 5, decidedly cut or toothed at the tip. Fruit a much enlarged dry pod. Maine to Kentucky, and westward. May. Fig. 524. See also Nos. $42 \mathrm{I}-424$.

525. Sleepy Catchfly. Silcne antirrhina. (Caryophyllaccae.) Somewhat resembling No. 524, but smaller, and the pink flowers about $1 / 4$ the size. In woods and in waste places. Maine to Florida, and westward. Not as common as No. 524, and not sticky. August. A related plant, S. Armeria, has larger flowers than No. 525, but not as large as No. 524, and occasionally escapes from gardens. See Nos. 42I-424. 
No. 526

\section{All the Flowers on Slender Stalklets Which Arise at the Same Point and Produce a Flower Cluster Known as an Umbel. See Figs. 527-555.}

(Nos. 527-555.)

The members of the Carrot Family are the best known of all the plants that have their flowers arranged in umbels, as shown in Figs. 527-555. But this characteristic is found also in the related Ginseng Family, and in a few other plants of widely different affinities. Sometimes the umbel is a single, and relatively simple affair, as in Fig. 536, or again it may be a greatly branched flower cluster. But however arranged, the ultimate unit of each cluster is always of separate flowers, or individual stalklets which arise at the same point. Of the two dozen, or so species here considered, about 20 are in the Carrot or Ginseng Families, the balance in the Spurge Family, and one, the Shooting Staf (No. 527) is in the Primrose Family. We may separate them all thus:

Leaves all compound (except no. 539) $\ldots \ldots \ldots \ldots \ldots \ldots$ no. 531

Leaves not compound

Leaves basal; plant without milky juice .. Shrooting Star no. 527

Leaves not basal, scattered along the stem; juice milky

Some of the leaves white-margined

.................. Snow-on-the-Mountain no. 528

Leaves green all over

Leaves oblong or roundish .......... Sun Spurge no. 529

Leaves narrowly oblong or linear... Cypress Spurge no. 530 527. Sirooting Star. Dodecatheon Meadia. (Primulaccac.) A perennial herb with basal toothless leaves and purple, or pink, rarely white flowers. Leaves oval-oblong, narrowed into a stalk, 4-12 in. long, and $1 / 2-3$ in. wide. Flowers in a terminal umbel, at first nodding, at length erect. Petals 5, slightly united at the base. Fruit a dry pod. On moist cliffs, and open prairies. Penn. to the mountains of Georgia, and westward. May. Fig. 527. See also Nos. 449, 466, 649, 69I, and $80 \mathrm{I}$, for other plants in this family. 

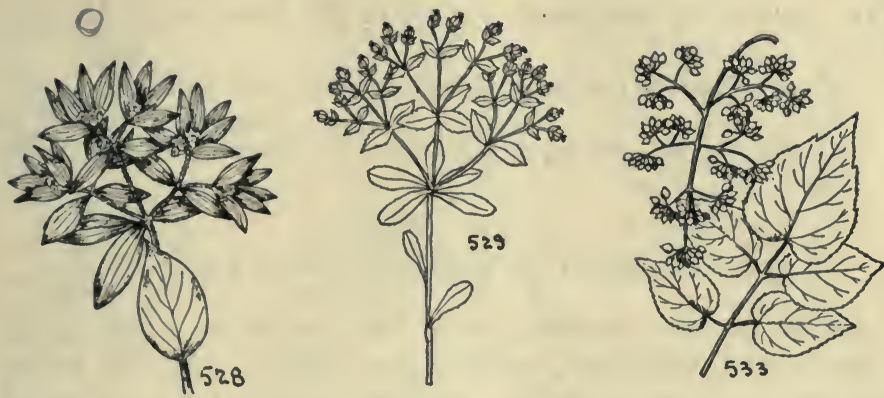

528. Snow-on-the-Mountain. Dicrophyllum marginatum. (Euphorbia marginata.) (Euphorbiaceae.) A milky-juiced annual herb, with alternate lower leaves, and with one cluster of 3 just below the flowers. Leaves oblong, or round-oblong, pointed both ends, about 2 in. long, the upper ones whitemargined. Flowers in a showy, leafy umbel, white. Native of the western U. S., cultivated eastward, and sometimes escaping. May-October. Fig. 528. See also Nos. 252, 268, 278, 419 and 447.

529. Sun Spurge. Tithymalus Helioscopia. (Euphorbia Hclioscopia.) (Euphorbiaccac.) A weedy European plant of waste places, with a milky juice, usually not over $\mathrm{I} 2 \mathrm{in.}$ tall. Lower leaves alternate, and one cluster of 5 just below the flowers. Leaves oblong, stalkless, finely toothed, except the upper ones, about 2 in. long. Flowers in a leafy umbel, greenish and not showy. Newfoundland to N. Y., and westward. June-October. Fig. 529. See also Nos. 252, 268, 278, 419, and 447 .

530. Cypress Spurge. Tithymalus Cyparissias. (Euphorbia Cyparissias.) (Euphorbiaceae.) A European weed somewhat resembling No. 529, but the upper leaves in clusters of 8 or Io, and linear-oblong, and with the umbel less leafy. Stems often scaly below. Flowers greenish-yellow. In waste places. Mass. to Virginia, and westward. June-October. See also Nos. 252, 268, 278, 419, and 447. 
53r. Leaves all compound, except in the Pennywort No. 539. (Nos. 532-555.)

Flower clusters (umbels) usually bracted (see details at no. 538) Carrot Family no. 538 Flower clusters not usually bracted .... Ginseng Family no. 532

\section{GINSENG FAMILY. ARALIACEAE.}

Often trees or shrubs, but a few are herbs in our range. Leaves all compound, sometimes doubly so, the leaflets coarsely or finely toothed. Flowers sometimes in a simple umbel (see Fig. 536), more often these umbels gathered into various, often much branched flower clusters. Each umbel is usually without the characteristic set of bracts which surround the base of such clusters in most of the plants of the Carrot Family (see Fig. 547). Fruit mostly fleshy. Our species may be separated thus:

Leaves twice or thrice compound

Plant 3-6 ft. high; umbels numerous ...... Spikenard no. 533

Plants I-2 ft. high; umbels usually 3-5

Flower cluster naked, arising directly from the ground ... ....................... Wild Sarsaparilla no. 534

Flower cluster terminating the leafy shoots ...............

Wild Elder no. 535

Leaves merely compound, the leaflets all arising at the same place.

Plant about 5 in. high or less ........ Dwarf Ginseng no. 536

Plant 8 in. high or more, usually much more .............

............................. Ginseng no. 537

533. Spikenard. Aralia racemosa. A much branched coarse woods herb, 3-6 ft. Leaves twice or thrice compound, I-3 ft. long, the ultimate leaflets oval, pointed, toothed, 2-6 in. long. Flowers in small umbels, these gathered into an immense and much branched cluster, greenish-white. Fruit a purplish-brown, or reddish berry, about $1 / 4$ in. in diameter. New Brunswick to Georgia, and westward. July. Fig. 533.

534. Wild Sarsaparilla. Aralia mudicaulis. Resembling No. 533 , but smaller in all its parts, and not usually over $\mathrm{I} / 2$ $\mathrm{ft}$. high. Leaf long stalked, twice compound, arising as if on a separate plant from the flower stalk, which is also naked and arises directly from the ground. Berries purplish-black, 

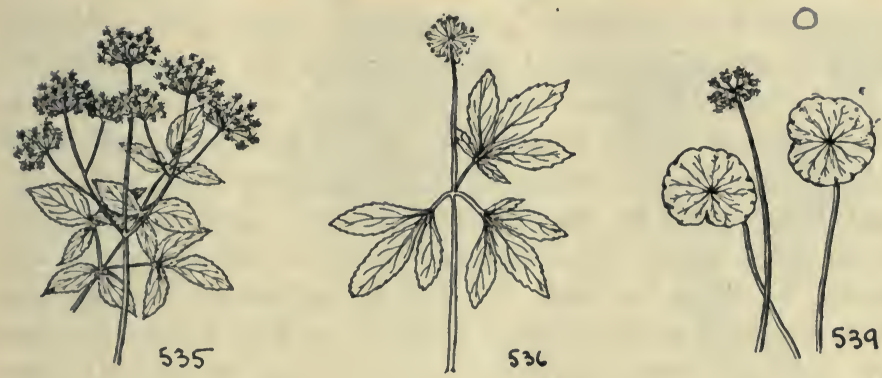

about $1 / 4$ in. in diameter. One of the commonest woods plants. New foundland to Georgia, and westward. May.

535. Wild Elder. Aralia hispida. A leafy-stemmed herb, bristly below, usually about $\mathrm{I} 1 / 2 \mathrm{ft}$. high. Leaves twice compound, the leaflets sharply toothed, I-2 in. long, and often hairy on the veins beneath. Umbels in a simple terminal cluster, the flowers white. Fruit dark purple, about $1 / 3$ in. in diameter, 5-angled, when dry. In dry open thickets, or along sea shores. Newfoundland to No. Carolina, and westward. June. Fig. 535 .

536. Dinarf Ginseng. Panax trifolium. A delicate plant of moist woods, not usually over 5 in. high. Leaves usually 3 , compound, with $3-5$ oval or oblong, toothed, stalkless leaflets that are about $I$ in. long. Flowers white, scarcely $1 / 10$ in. wide, the umbel usually about $3 / 4$ in. wide. Fruit yellow. Nova Scotia to Georgia and westward. May. Fig. 536.

537. Ginseng. Panax quinquefolium. Suggesting No. 536, but taller, and with 5 stalked oval leaflets, about $2 \frac{1}{2}$ in. long. Flowers greenish, fruit bright red. Formerly in rich woods, now very rare because of its collection for export to China as a reputed medicine. Quebec to Alabama. Often cultivated for its roots. July.

538. CARROT FAMILY. AMMIACEAE. (UMBELLIFERAE.)

A large and important family of plants containing, besides the carrot, the parsley, celery, parsnip, and several aromatic 
herbs, such as coriander and caraway. They have alternate, twice or thrice compound leaves (except the Pennywort. No. 539) which are often finely dissected, and the leaf-stalks often dilated at the base, as in celery. Flowers small, often minute, but always arranged in umbels (see Figs. 527-555), and these may be themselves arranged in larger umbels, or in other ways. The ultimate umbel or the aggregate collection of them, or both, are usually surrounded at the base by a series of small or large bracts (see Fig. 547), but these are lacking in the Parsnip, No. 554, and in the Meadowparsnip No. 555. Petals 5, fruit dry, usually ribbed. The species are difficult to identify, and some, without dissection of their fruits to ascertain technical characters, cannot be. Only the best known and most easily identified are included here:

Flowers yellow $\ldots \ldots \ldots \ldots \ldots \ldots \ldots \ldots \ldots \ldots \ldots \ldots$ no. $55 \mathrm{I}$

Flowers white, or greenish white

Leaves undivided, round, the leaf-stalk attached to the middle of the leaf-blade .................. Pennywort no. 539

Leaves compound, often finely dissected.

Plants at least $4 \mathrm{ft}$. high, often 6 or $8 \mathrm{ft}$., usually growing in moist places

Plants white hairy; leaves often $2 \mathrm{ft}$. wide, the ultimate segments $3-6$ in. wide ............. Cow-parsnip no. 540

Plants not hairy; leaves smaller, the ultimate segments not over 2 in. wide.

Veins of the leaflets ending in the notch between the marginal teeth ............ Water Hemlock no. 54I

Veins of the leaflet scarcely reaching the margin, if so, not ending in the notch ....... Great Angelica no. 542

Plants usually less than $3 \mathrm{ft}$. high, often less than $2 \mathrm{ft}$.

Ultimate leaf-segments thread-like

Ultimate leaf-segments wider

Ultimate leaflets arranged finger-fashion

........................ Black Snakeroot no. 544

Ultimate leaflets arranged feather-fashion.

Woods plants.

Hairy; fruits about $1 / 2$ in. long .................

.................... Sweet Cicely no. 545

Without hairs; fruits about $1 / 4$ in. long ...........

Plants of waste places or fields

Honewort no. 546

Bracts under the flower cluster dissected 

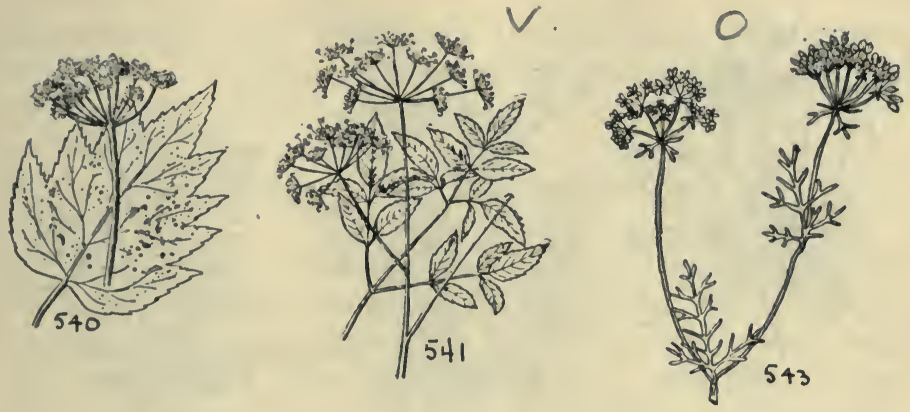

Wild Carrot no. 547 Bracts under the flower cluster not dissected ...... Plants of wet places

Of salt meadows ............ Sea Lovage no. 549

Of fresh water places

Poison Hemlock no. 548

Hemlock water-parsnip no. 550

539. Pennywort. Hydrocotyle umbellata. A low plant of wet places, not over 5 in. high, the nearly round scallopededged leaves with the leaf-stalk attached to the center of the blade. Flower minute, in a simple umbel which stands above the leaves. July-September. Mass. to Florida, and westward. Fig. 539. There are several closely related species, one of them, $H$. americana, has the leaf-stalks attached to the edge of the blade, and few-flowered umbels that are hidden by the leaves. It is found from Nova Scotia to No. Carolina and westward.

540. Cow-PARSNip. Heracleum lanatum. An immense herb, often $8 \mathrm{ft}$. tall, with white hairy stems and foliage. Leaves usually at least $2 \mathrm{ft}$. wide, thrice compound, the ultimate segments $3^{-6}$ in. wide, lobed and toothed. Flower cluster white, 6-i 2 in. wide, its chief bracts almost none. Bracts of the final umbels fine and thread-like. Fruit broadly oval, about $1 / 4$ in. broad, hairy. In moist places. Newfoundland to No. Carolina, and westward. June. Fig. 540.

54I. Water Hemlock. Cicuta maculata. A smooth, branching herb, with a purple lined stem, 4-6 ft. high. Leaves thrice compound, the ultimate segments about $I \frac{1}{2}$ in. wide, the veins ending in the notch between the marginal teeth. 

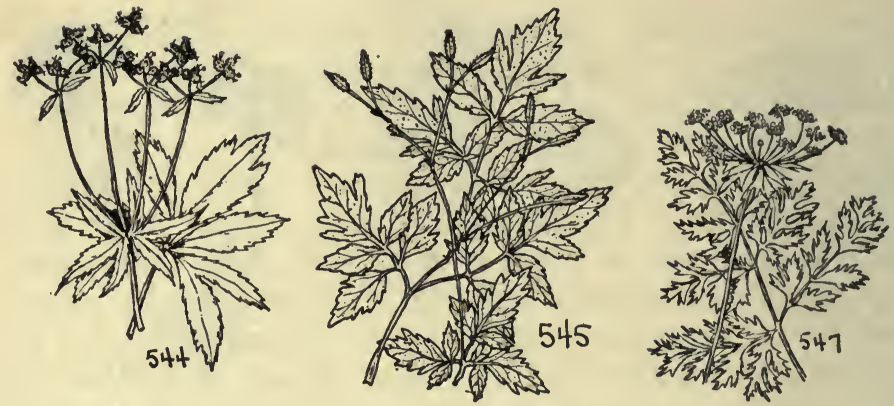

Flowers white, in a compound umbel, the ultimate umbels many flowered. Fruit 'nearly globular, about $1 / 10$ in. in diameter. Wet places. New Brunswick to Florida, and westward. July. Fig. 54I.

542. Great Angelica. Angelica atropurpurca. Somewhat re. sembling No. 54I, but purple stemmed, and the leaf segments wider, less deeply toothed, and with the veins not ending in the notch between the teeth. Umbels often 8 in. wide. In wet places. Newfoundland to Delaware, and westward, very common. June.

543. Mock Bishop-Weed. Ptilimnium capillaccum. Usually a salt marsh plant, rare in fresh marshes, and not over I5 in. high, and weak. Leaves finely dissected, the ultimate divisions thread-like. Flowers white, in a small umbel, not over $3 \frac{1}{2}$ in. wide, the general cluster bracted. Mass. to Florida and Texas. June-October. Fig. 543 .

544. Black Snakeroot. Sanicula marylandica. Woods herb with smooth, usually unbranched stem, mostly $I^{1} / 2-2 \mathrm{~T} / 2 \mathrm{ft}$. high. Leaves compound, the leaflets arranged finger-fashion, toothed, but scarcely lobed. Umbels rather long-stalked, the bracts leafy, lobed and toothed. Flowers greenish-white, inconspicuous. In woods. New foundland to Georgia, and westward. June. Fig. 544. There are several other species, omitted here, as they are difficult to identify.

545. Sweet-Cicely. Washingtonia Claytoni. (Osmorhiza Claytoni.) A hairy woods plant, not over $2 \frac{1}{2} \mathrm{ft}$. tall, the 
leaves many times compound. Leaflets arranged featherfashion, the ultimate segments lobed and toothed. Umbels few flowered, white, followed by a shiny, bristly beaked fruit, about $1 / 2$ in. long. Foliage and especially the roots fragrant. Nova Scotia to No. Carolina and westward. June. Fig. 545 .

546. Honewort. Deringa canadensis. (Cryptotaenia canadensis.) Somewhat resembling No. 545, but leaves not so much cut, the ultimate segments more lobed but less toothed, and without hairs. Fruit about $1 / 4$ in. long, not beaked at the tip. In rich woods. New Brunswick to Georgia, and westward. June.

547. Wild Carrot. Daucus Carota. One of the commonest European weeds in America. Leaves much dissected, the leaf stalk and stalklets often bristly. The general umbel has below it a set of dissected bracts. Flowers minute, white. Fruit bristly. In waste places everywhere. Ancestor of the carrot. June-September. Fig. 547.

548. Porson Hemlock. Conium maculatum. A poisonousjuiced plant said to have been the poison hemlock that killed Socrates. Stems erect, branched, usually $2-3 \mathrm{ft}$. tall. Foliage and flowers not unlike No. 547, but the umbel with bracts not dissected, and the fruit not bristly. In waste places. Nova Scotia to Delaware, and westward. Native of Europe. June. 549. Sea Lovage. Ligusticum Scoticum. A coarse salt marsh plant with mostly unbranched stems, I-2 $1 / 2 \mathrm{ft}$. tall. Leaves mostly twice compound, the ultimate segments thick, fleshy, broadly oval, and with rather blunt teeth. Umbels 2-4 in. wide, compound, white. Fruit ribbed, but not bristly, about $1 / 3$ in. long. From the eastern tip of Long Island, N. Y., to the lower St. Lawrence River and Labrador. July. Fig. 549. 550. Hem lock Water-parsnip. Sium cicutacfolium. A fresh water marsh or swamp plant with an erect branched stem 2-4 ft. tall. Basal leaves much dissected. Stem leaves merely compound, the opposite narrowly oblong leaflets toothed and 2-4 in. long. Umbel compound, bracted, the bracts not divided, flowers white. Nova Scotia to Florida, and westward. July-October. Fig. 550. 

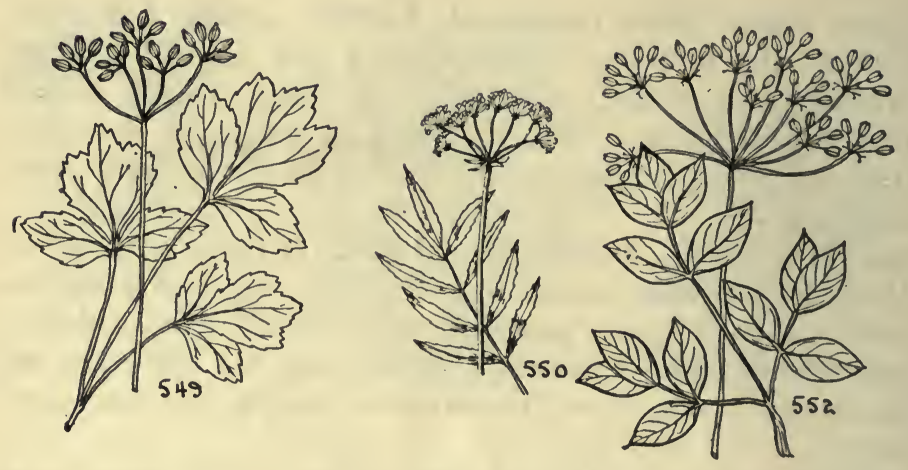

551. Flowers yellow. (Carrot Family concluded.)

Leaflets without teeth ........... Yellow Pimpernel no. 552 Leaflets coarsely or finely toothed

Main umbel bracted .................. Lovage no. 553

Main umbel not bracted, but the ultimate ones sometimes with small bracts.

Leaflets lobed and toothed; plants 2-5 ft....Parsnip no. 554

Leaflets merely finely toothed ..... Meadow-parsnip no. 555

552. Yellow Pimpernel. Taenidia integerrima. A smooth perennial, usually branched, and I-3 ft. high. Leaves thrice compound, the oval, pointed, stalkless leaflets without teeth. Main umbel about 3 in. wide, yellow, without bracts. Fruit oval, about $1 / 6$ in. long, smooth. In dry places. Quebec to No. Carolina, and westward. June. Fig. 552.

553. Lovage. Hipposelinum Levisticum. (Levisticum officinale.) A coarse, stout branched perennial up to $6 \mathrm{ft}$. high. Leaves large, many times compound, the ultimate segments wedge-shaped, with a few coarse teeth or lobes toward the tip. Umbel about 3 in. wide, conspicuously bracted, yellow. Fruit smooth, but ribbed. Escaping from gardens. Vermont to Penn. Native of Europe. June-August. Fig. 553.

554. Parsnip. Pastinaca sativa. A stout herb with a grooved stem 2-5 ft. high. Leaves once or twice compound, the ultimate segments coarsely lobed and toothed, essentially stalkless. Flowers yellow in a large bractless umbel, the small 


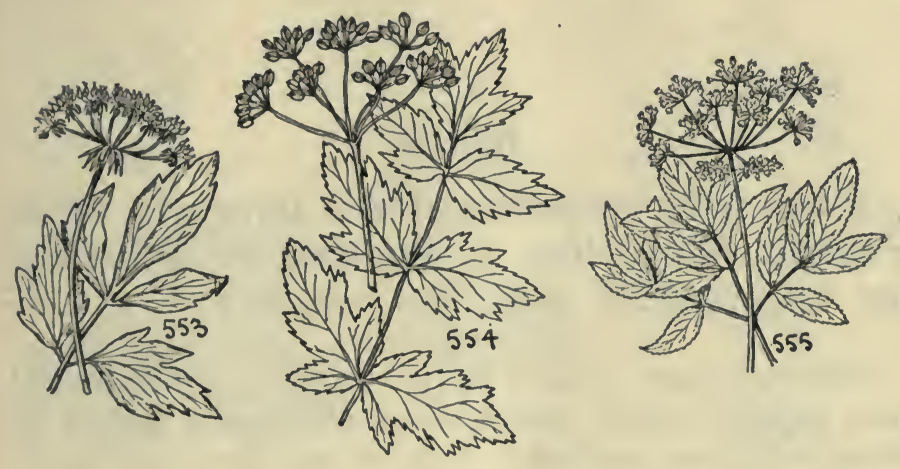

umbels also without bracts. Fruit broadly oval or round, ribbed. Common as a weed nearly everywhere. Native of Europe. June-September. Fig. 554.

555. Meadow Parsnip. Zizia aurea. An erect, smooth, usually branched herb, I-2 ft. high, with long-stalked thrice compound leaves. Leaf-segments oval, sharply but not deeply toothed, very short stalked. Flowers yellow, in a bractless umbel, but the smaller umbels with small bractlets. Fruit oblong, smooth, but ribbed. In meadows. New Brunswick to Florida, and westward. May. Fig. 555. A related species, $Z$. cordata, has basal leaves that are heart shaped. There is also a plant of a different genus, Thaspium barbinode, which looks much like No. 555, and is to be separated only by technical characters. 
No. 556

\section{Flowers Unsymmetrical and Irregular, Often Pea-like, Violet-like, or Spurred, or Otherwise not symmetrical. See Figs. 558-62 I.}

(Nos. 557-62 I.)

There are about 50 wild flowers in this group. Nearly all have separate petals, but these are not regular and of the usual shape, but modified to form an unsymmetrical and irregular flower. Sometimes there is a distinct spur, as in the Columbine, Jewel-weed, and the Violets. Others are pea-like, as in the garden Sweet-pea, while in the Milkworts, the sepals are unequal in length and some of the petals slightly united to form a short tube. The whole group may be divided thus:

Flowers irregular, but not spurred $\ldots \ldots \ldots \ldots \ldots \ldots \ldots$ no. 583

Flowers with one or more petals produced into a spur (See Fig. 558-582)

Leaves not divided or dissected, except in some violets (See no.

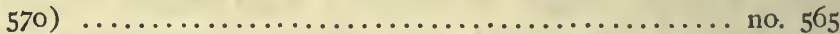
Leaves compound, or divided, or dissected

Flowers blue or crimson $\ldots \ldots \ldots \ldots \ldots \ldots \ldots \ldots$ no. 562

Flowers white, yellow, or pinkish purple

Fumewort Family no. 557

\section{FUMEWORT FAMILY. FUMARIACEAE.}

Weak and quickly wilting herbs with dissected, usually smooth, leaves. Flowers in various kinds of clusters, with 2 sepals and 4 petals, some of which unite to form a spur at the base of the flower. Fruit a dry pod. (For the Climbing Fumitory see, among the vines, No. 236.)

Leaves wholly basal; flowers cream white $\ldots . . . \ldots \ldots \ldots . . . .$.

....................... Dutchman's Breeches no. 558

Leaves partly basal, but some borne on the stem

Spurs yellow ................. Golden Corydalis no. 559

Spurs yellow, tipped with pink ........ Pink Corydalis no. 560 Spurs purplish-pink .............. Hedge Fumitory no 56I 

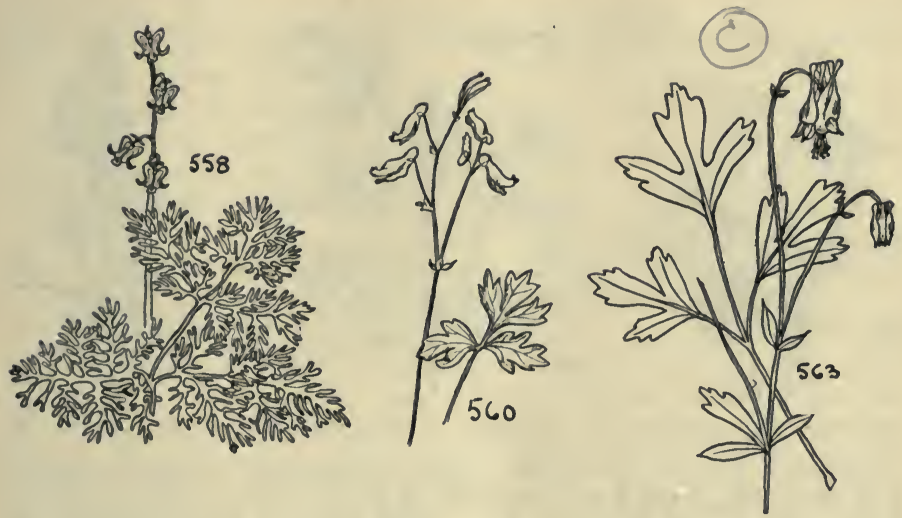

558. Dutchiman's Breeches. Bicuculla Cucullaria. (Dicentra Cucullaria.) A delicate woods plant with a bulbous base, and wholly basal dissected leaves that are pale beneath, and with the ultimate segments stalked and finely dissected. Flowers in a terminal raceme, cream white, the tips of the spurs spreading. Nova Scotia to No. Carolina, and westward. May. Fig. 558. A related plant, B. canadensis, with the tips of the spurs almost touching is found at higher elevations. The garden Bleeding Heart, B. eximia, has pink spurs and is rare as a wild plant from western N. Y. to Georgia, and westward. It sometimes escapes from cultivation eastward. 559. Golden Corydalis. Capnoides aureum. (Corydalis aurea.) A weak rather sprawling herb with basal and stem leaves that are dissected. Flowers as in No. 560, but pure yellow, and about half as long. Pods curved and beaked. In woods. Nova Scotia to Penn., and westward. April. 56o. Pink Corydalis. Capnoides sempervirens. (Corydalis sempervirens.) A smooth bluish-green herb, 8-20 in. high. Basal and stem leaves dissected, the ultimate segments wedgeshaped and bluntly toothed or lobed. Flowers numerous, in clusters at the ends of the branches, the yellow, pink-tipped spurs about $I$ in. long. Pod straight and beaked, about $I^{1} / 2$ in. long. In rocky woods. Nova Scotia to Georgia and westward. April-Sept. Fig. 560. 561. Hedge Fumitory. Fumaria officinalis. A weak herb, 


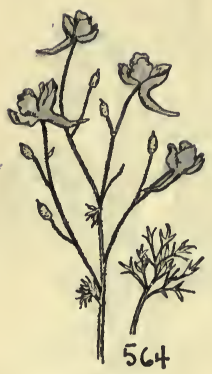

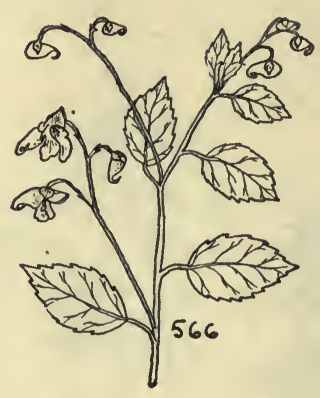

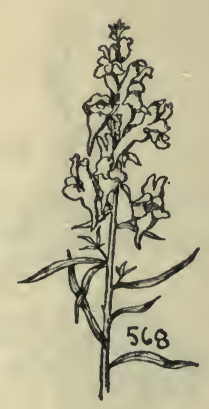

I-4 ft. long, rarely erect, mostly sprawling. Leaves stalked, finely dissected. Flowers in a long raceme from among the leaves. Spurs purplish-pink, about $1 / 4$ in. long. Pod round, about $1 / 8$ in. in diameter. In waste places. Newfoundland to Florida. Rare in the interior. Native of Europe. August. 562. Flowers blue or crimson.

Flowers crimson $\ldots \ldots \ldots \ldots \ldots \ldots \ldots$ Columbine no. 563

Flowers blue ................. Rocket Larkspur no. 564 563. Columbine. Aquilegia canadensis. (Ranunculaceae.) A delicate plant of rocky woods with basal and stem leaves that are thrice compound. Ultimate leaf segments pale, wedge shaped, deeply lobed, and with rounded blunt teeth. Flowers crimson, rarely yellowish, the five spurs all with a terminal knob. Fruit a collection of 5 beaked pods. Nova Scotia to Florida, and westward. May. Fig. 563. The garden Columbine, $A$. vulgaris, has blue flowers, and sometimes escapes. It is a native of Europe. See No, 349.

564. Rocket Larkspur. Delphinium Ajacis. (Ranunculaceae.) An annual weedy plant I-3 ft. high, branched, and more or less hairy. Leaves finely dissected into almost threadlike segments. Flowers blue, almost I in. long, in an open cluster, with a single rather long and curved spur. Fruit dry, hairy, beaked. In fields and waste places. Nova Scotia to So. Carolina, and westward. July. Fig. 564. A taller plant, D. exaltatum, with coarser leaves not so finely dissected and with hairy flowers, is found from Penn. to Ala. and westward. See No. 349. 
565. Leaves not divided, or dissected; except in some violets

No. 570. (Nos. 566-582.)

Flowers violet-like (see Figs. 57I-582) ........ Violets no. 570

Flowers not violet-like.

Leaves oval and stalked

Flowers orange yellow, mottled .....................

..................... Spotted Touch-me-not no. 566

Flowers pale yellow .......... Pale Touch-me-not no. 567

Leaves narrowly linear, essentially stalkless.

Flowers yellow, about $\mathrm{I}$ in. long ........ Toadflax no. 568

Flowers lavender, about $1 / 3$ in. long $\ldots \ldots \ldots \ldots \ldots \ldots$ 566. Spotted Touch-me-not. Impatiens biflora. (Balsaminaccae). An annual, smooth, rather weak herb with glistening foliage. Leaves oval, $1 \frac{1}{2}-3$ in. long, irregularly but not deeply toothed, stalked. Flowers few, in an open sparse cluster, or solitary, orange-yellow and mottled with reddish brown spots. Spur rather short and blunt. Fruit an oblong pod, which splits open suddenly and ejects the ridged seeds with some violence. In moist places. Newfoundland to Florida and westward. July-October. Fig. 566.

567. Pale Touch-me-not. Impatiens pallida. (Balsaminaceae.) Very similar to No. 566 , but with a pale yellow, unmottled flower. In similar places, but more abundant northward and away from the coast. July-September.

568. Tond-Flax. Butter-and-EgGs. Linaria Linaria. (Linaria vulgaris.) (Scrophulariaceae.) A beautiful European plant, found as a weed throughout the area, and usually 8-20 in. high. Leaves alternate, linear, stalkless, about $I \frac{1}{2}$ in. long, and $1 / 4$ in. wide. Flowers in a showy, dense, terminal raceme, long-spurred, about $\mathrm{I}$ in. long, yellow with an orange throat. In field and roadsides, nearly everywhere. June-September. Fig. 568. See No. 78I.

569. Blue Toad-flax. Linaria canadensis. (Scrophulariaceae.) A delicate smooth erect herb, mostly under I 5 in. high, with alternate very narrow leaves that are about $3 / 4$ in. long, and stalkless. Flowers in a loose, rather sparse, terminal raceme, pale lavender or violet, not over $1 / 3$ in. long. Spur thin and thread-like. In dry sandy places. Maine to Florida, and westward. June-September. See No. 78I. 


\section{VIOLETS. VIOLA.}

A large group of native violets are found in various situations, but mostly in rich moist woods. Many of them are stemless, the leaf stalk and flower stalk arising directly from the ground. Others have true stems above ground. Leaves characteristically heart-shaped in most species, but sometimes oval or oblong, or divided into segments. Flowers white, violet or yellow, usually solitary, or in very sparse clusters, always spurred and bearded inside in most species. In all except the Bird's-foot Violet, No. 57r, there is another set of flowers that are fertile, uncolored, never open, and are borne near the ground. The species hybridize, are difficult to identify, and only the commonest of over 40 sorts are included here.

Plants stemless, the leaves and flower stalks arising directly from the ground.

Flower of two colors, dark violet and pale lavender, beardless; leaves dissected; plant of dry sandy places ................ ...................... Bird's-foot Violet no. 57I

Flower of uniform color, always bearded on the inside.

Flowers yellow ................ Yellow Violet no. 572 Flowers white.

Leaves lance-shaped ............. Water Violet no. 573 Leaves roundish, heart-shaped at the base

Flowers pale or deep violet or violet blue

Roots fibrous, not thickened

Rootstock thick, not fibrous

Leaves not cut, sometimes wavy-margined, or toothed

Leaves hairy ........... Woolly Blue Violet no. 576 Leaves not hairy

Leaves usually $3-4$ in. wide

.Common Blue Violet no. 577

Leaves usually $2^{1 / 2}$ in. wide

Leaves with the blades more or less deeply cut.

Leaves cut mostly towards the base

.................. Arrow-leaved Violet no. 579

Leaves cut towards the middle

Early Blue Violet no. 580 

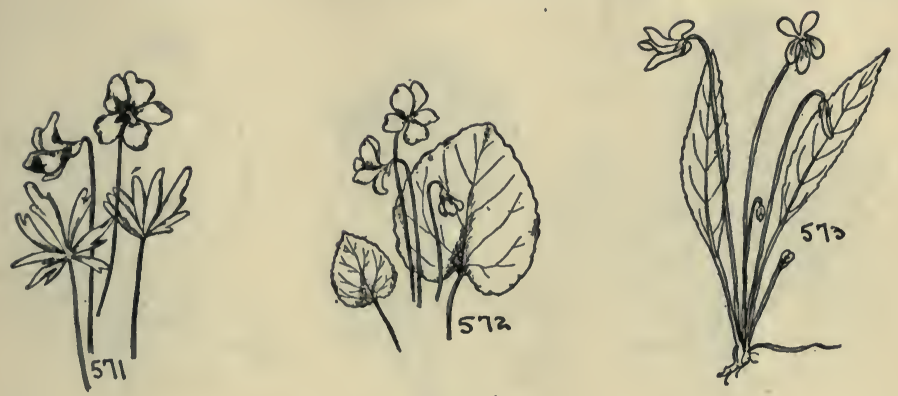

Plants leafy-stemmed, the flowers from among the leaves

Flowers yellow ................. Yellow Violet no. 58I

Flowers violet-white ............... Canada Violet no. 582

57 I. Bird's-foot Violet. Viola pedata. A stemless violet with much divided leaves. Flowers with three lower petals pale lilac-purple, the two upper ones dark violet, showy, and usually overtopping the leaves. In dry places. Mass. to Florida, and westward. May. Fig. 57 I.

572. Yellow Violet. Viola rotundifolia. A stemless yellow violet, very different from the yellow violet with a stem (No. 58I). Leaves oval or round, rather thick, shallowly heart-shaped at the base, wavy-margined, but scarcely toothed, about 3 in. wide, lying flat on the ground when old. Flowers yellow, much overtopping the leaves. In cool woods. Maine and Ontario, south along the mountains to Georgia. May. Fig. 572.

573. Water Violet. Viola lanceolata. A smooth stemless violet with narrow lance-shaped leaves tapering into a long leaf-stalk. Flowers about the same height as the leaves, white, but purple-veined. In moist places. Nova Scotia to Florida and westward. May. Fig. 573. A related plant, $V$. primulifolia, has wider leaves, but similar flowers and is found along the coast from Nova Scotia to Florida.

574. White Violet. Viola blanda. A stemless, smooth violet with roundish, pointed leaves, deeply heart-shaped at the base, about $\mathrm{I} / 2$ in. wide. Flowers white. In cool or moist places. Quebec to the mountains of Georgia, and westward. May. Fig. 574. There are several close relatives, all white flowered, 

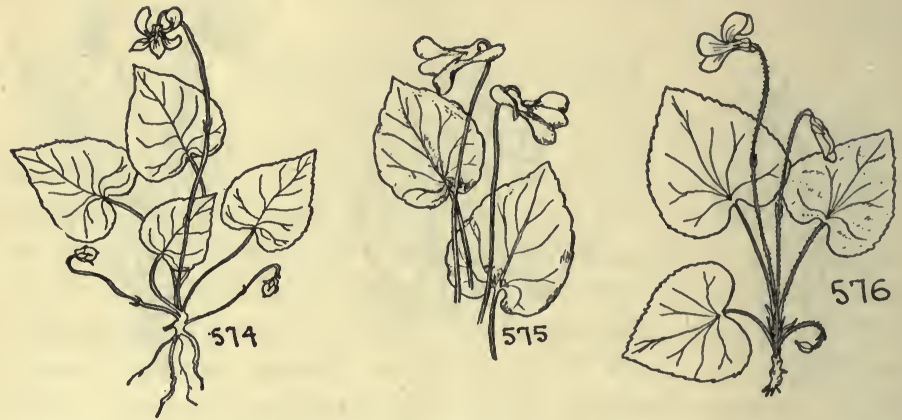

and distinguished by technical characters. One of them is $V$. pallens which is covered with fine hairs, and is more common along the coast than $V$. blanda.

575. Great Spurred Violet. Viola Selkirkii. A stemless violet with heart-shaped leaves that are slightly hairy on the upper surface. Flowers pale violet, longer spurred than in most species, beardless. Roots fibrous. In mountain forests. New Brunswick to Penn., and westward. May. Fig. 575. 576. Woolly Blue Violet. Viola sororia. A hairy, stemless violet with roundish, scarcely pointed leaves that are only slightly heart-shaped at the base. Flowers pale violet, usually overtopping the leaves. Rootstocks thick. In moist places. Quebec to No. Carolina, and westward. May. Fig. 576. 577. Common Blue Violet. Viola papilionacea. More common than No. 576 , and resembling it, but differing in not having hairy leaves and in being larger, frequently $3^{-4}$ in. wide. Flowers deep violet, usually about the height of the leaves. Rootstock thick. In moist places. Mass.. to Georgia, and westward. May.

578. Marsh Blue Violet. Viola cucullata. Very like Nos. 576 and 577 , but with smooth foliage, and leaves usually not over $2 \frac{1}{2}$ in. wide. Flowers violet-blue, about the height of the leaves. Rootstock thick. In wet places. Quebec and Ontario to Georgia. May. Fig. 578.

579. Arrow-leaved Violet. Viola sagittata. A smooth, stemless violet, the flowers about the height of the foliage. Leaves 

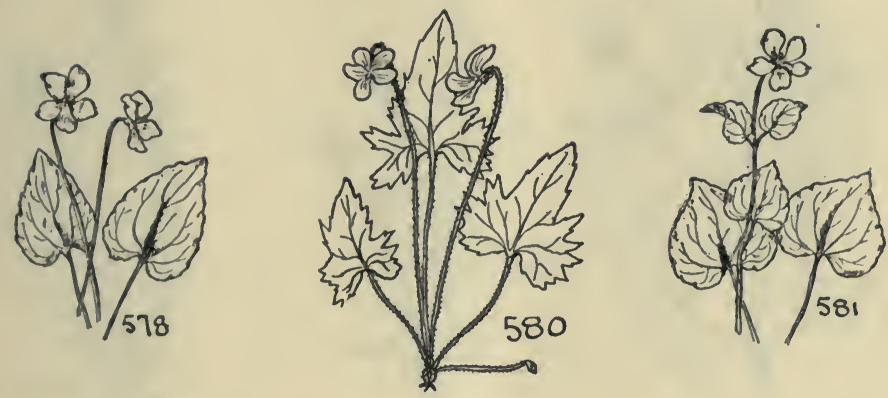

more or less arrow-head shaped, but heart shaped at the base, where there are several deep notches, the rest of the leaf almost toothless. Flowers violet purple. In moist places. Mass. to Georgia, and westward. May. There are several close relatives too difficult to separate here.

580. Early Blue Violet. Viola palmata. Not unlike No. 579 , but the leaf notches deeper, and extending farther up the more triangular shaped hairy leaves. Flowers violetpurple, $3 / 4-11 / 4$ in. wide, and larger than in No. 579. In woods. Mass. to Florida, and westward. May. Fig. 580.

581. Yellow Violet. Viola criocarpa. A leafy-stemmed, smooth violet with yellow flowers. Basal leaves longer stalked than the stem leaves, all of them heart-shaped, pointed, faintly toothed. Flowers one or two together from the leaf insertion on the stem. In woods. Nova Scotia to Georgia and westward. May. Fig. 581. A hairy relative, V. pubescens, is more common in the mountains.

582. Canada Violet. Viola canadensis. A leafy-stemmed violet from 8-16 in. long. Stem leaves stalked, heart-shaped at the base, tapering to a pointed tip, toothed. Basal leaves similar, but longer stalked. Flowers solitary from the leaf joints, violet-white, tinged with yellow, often dark veined. In woods, especially in the uplands. New Brunswick to So. Carolina, and westward. June. Fig. 582. There are several close relatives. Often replaced along the coast by $V$. conspersa, which has pale violet flowers raised above the leaves. 

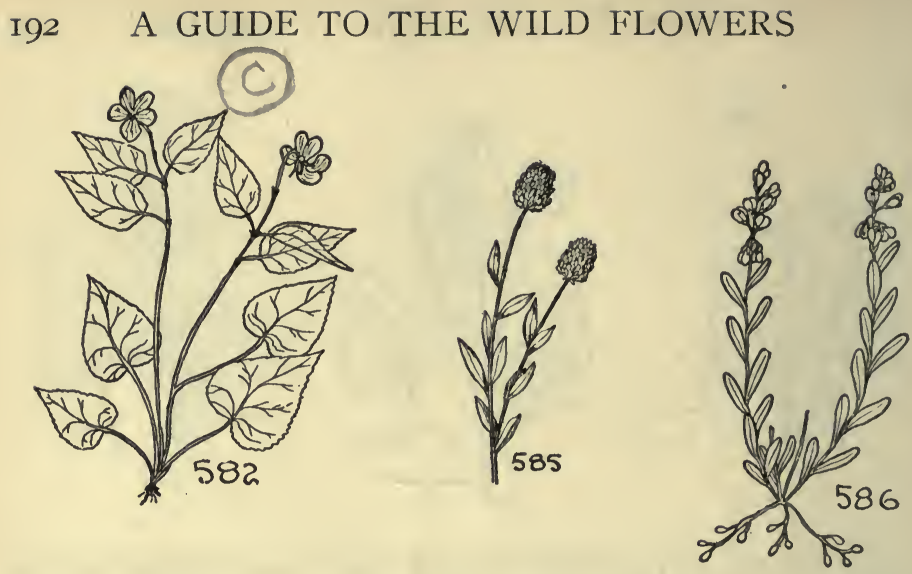

583. Flowers irregular and unsymmetrical, but not spurred. (Nos. 584-621.)

Leaves compound (except in no. 593); flowers pea-like (see Fig. 593-621) ................... Pea Family no. 592 Leaves all simple .................... Milkworts no. 584

\section{MILKWORTS. POLYGALA.}

Mostly slender herbs with opposite, alternate or clustered, always simple and toothless leaves. Flowers in various kinds of clusters, or nearly solitary in one species. Sepals 5, 2 of them larger and colored, the others smaller. Petals 3 or 5 , more or less united into a tube, one of them often crested or fringed. Fruit a small dry pod. (Polygalaceac.)

Flowers yellow ................... Orange Milkwort no. 585

Flowers not yellow.

Flowers in spikes or racemes.

Individual flowers on recurved stalklets $\ldots \ldots \ldots \ldots \ldots \ldots$ ......................... Bitter Milkwort no. 586 Individual flowers on erect stalklets, or in tight spikes

All the lower leaves clustered in fours $\ldots . . . \ldots \ldots . . .$. ....................... Marsh Milkwort no. 587 Leaves clustered and alternate...Whorled Milkwort no. 588 Leaves all alternate.

Spikes blunt; flowers rose purple

.................... Purple Milkwort no. 589 

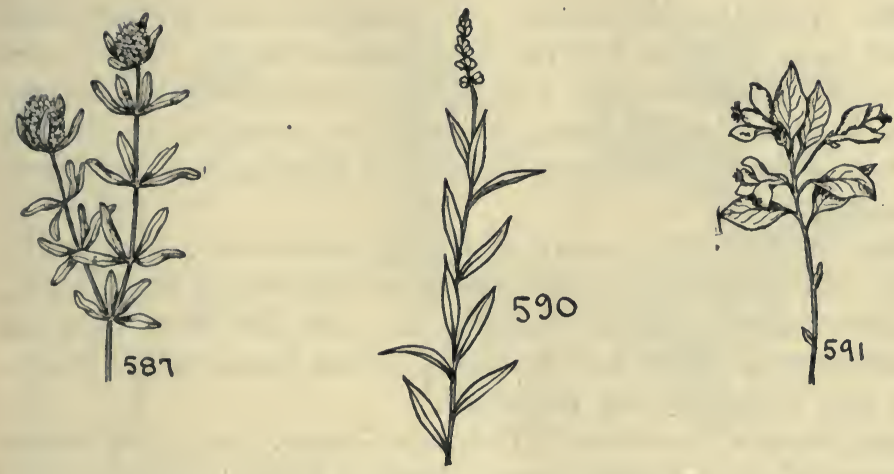

Spikes pointed; flowers greenish white $\ldots \ldots \ldots \ldots \ldots \ldots$ Seneca Snakeroot no. 590

Flower I or a few, not in spikes or racemes; petals purple, fringed; plant prostrate ............. Gay Wings no. 59I 585. Orange Milkwort. Polygala lutea. An annual, smooth, bog herb, with alternate, oblong, or lance-shaped leaves $3 / 4$ $\mathrm{I} 1 / 4$ in. long. Flowers small, orange-yellow, densely packed in a tight spike or raceme, which terminates the naked upper part of the branches, and is about $3 / 4$ in. thick. In pine barren bogs, along the coast. Long Island, N. Y., to Georgia and Louisiana. August. Fig. 585 .

586. Bitter Milkwort. Polygala polygama. A stiff, almost woody plant, usually 6-9 in. high, with alternate or scattered, oblong leaves, about $I$ in. long, and tipped with a fine point. Flowers rose-purple, rarely white, in terminal rather loose racemes, each stalklet of which is recurved. The plant also bears tiny underground flowers that never open. In dry open places. Nova Scotia to Florida, and westward. July. Fig. 586.

587. Marsh Milkwort. Polygala cruciata. A smooth annual herb, usually branched, 6-12 in. high, and with a square or angled stem. Leaves blunt, at least the lower in clusters of 4 , tapering towards a stalkless base. Terminal racemes short-stalked, blunt, about $5 / 8$ in. thick, purple, greenish or white. In bogs. Maine to Florida, and westward. August. Fig. 587. 
588. Whorled Milkwort. Polygala verticillata. More slender than the last, but the upper leaves in 4's or 5's and pointed. Flower cluster long stalked, sharp pointed, scarcely $1 / 4$ in. thick at the base, greenish or purplish. In dry or moist places. Quebec and Ontario to Florida, and westward. August.

589. Purple Milkwort. Polygala viridescens. Not unlike No. 587 in having usually rose purple flowers in thick, blunt, short-stalked racemes. But in No. 589 the leaves are all alternate. In fields and meadows. Nova Scotia and Ontario to No. Carolina, and westward.

59o. Seneca Snakeroot. Polygala Senega. An almost woody perennial with several stems from a single root, 8-I5 in. high, rather stiff and erect. Leaves alternate, stalkless, tapering both ends, I-2 in. long, except the lower ones which are much smaller and scale-like. Flowers greenish-white, in a loose, long-stalked spike. In rocky woods. New Brunswick to No. Carolina, and westward, mostly in the uplands. June. Fig. 590.

59r. Gay-wings. Polygala paucifolia. A prostrate plant, wholly unlike all the other Milkworts in habit, with oval, pointed, stalked leaves, clustered irregularly towards the ends of the branches. Plant $6-\mathrm{I} 2$ in. long. Leaves $\mathrm{I}-\mathrm{I} \mathrm{I} / 2$ in. long, about half as wide, the lower ones much smaller. Flowers showy, I or 2 , rarely more, from the leaf joints, rose-purple, beautifully fringed, about $3 / 4$ in. long. In moist woods. New Brunswick to Georgia and westward. May. Fig. 59I.

\section{PEA FAMILY. FABACEAE. (NOS. 593-621.)}

A large and important family of plants, containing a pea, bean, clover, and peanut among its more than 5,000 species, found throughout the world. Our species are trees, shrubs, or herbs, and among the wild flowers here included, the leaves are always alternate and compound, except in the Rattle-box, No. 593. Sepals 4 or 5, united to form a usually unequal tube which is sometimes slightly 2-lipped. Petals somewhat united or quite free, with one broad and banner- 

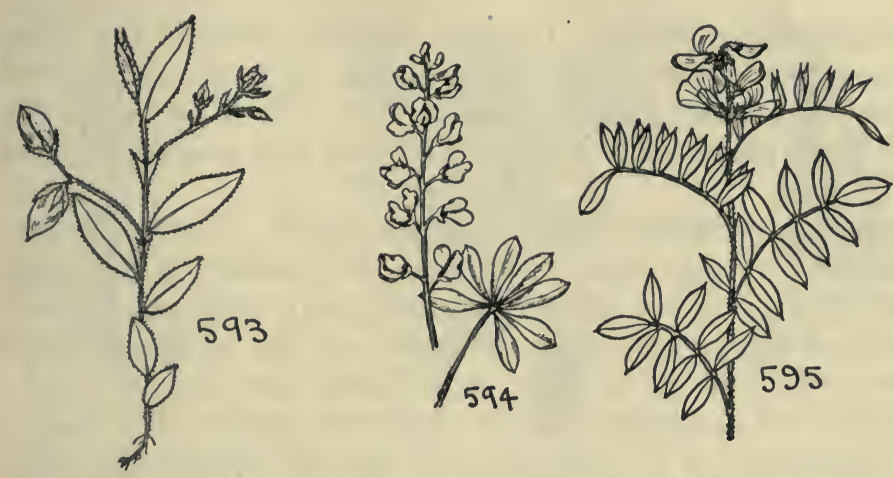

like, 2 lateral ones wing-like, and the other 2 more or less united into a keel. A common example is the sweet-pea, but sometimes the flowers are smaller and crowded into tight clusters like the clover. Fruit a legume, of which the garden pea is a typical illustration. Sometimes the pods are shorter than in the pea. The family is often called Papilionaceae (Papilio-butterfly, from the resemblance of the flower to a butterfly). For the vines of this family see Nos. 216-234. Of the scores of species known in the area, the following may be separated thus:

Leaflets 3 .............................. no. 596 Leaflets 1 ....................... Rattle-box no. 593 Leaflets more than 5

Leaflets arranged finger-fashion; flowers blue .... Lupine no. 594 Leaflets arranged feather-fashion; flowers yellow-purple ....... .......................... Wild Sweet-pea no. 595 593. Rattle-Box Crotalaria sagittalis. An annual low weed, softly hairy, rarely over Io in. high. Leaflets I (appearing as though with simple leaves, but actually compound and restricted to I leaflet), almost stalkless, oval, or oblong-oval, pointed both ends, about $1 \mathrm{r} / 2$ in. long. Flowers yellow, the sepals long-pointed and hairy. Pod smooth, black, inflated when ripe, so that the shining seeds rattle in a cavity too big for them. In dry places. Vermont to Florida, and westward. July-August. Fig. 593.

594. LuPINE. Lupinus perennis. A hairy perennial of dry soil, I-2 ft. tall with compound leaves, the 7-I l leaflets ar- 


\section{I96 A GUIDE TO THE WILD FLOWERS}

ranged finger-fashion. Leaflets broadest towards the blunt tip, which is furnished with a minute soft prickle. Flowers blue, in a showy terminal cluster. Pods very hairy, about $\mathrm{I} 1 / 2$ in. long. Maine and Ontario to Florida, and westward. June. Fig. 594 .

595. Wild Sweet-Pea. Cracca virginiana. (Tephrosia virginiana.) A silky hairy, ashy grey herb, usually rather weak and sprawling, I-2 ft. high. Leaflets 9-2I, arranged featherfashion in opposite pairs, with an odd one at the end, not toothed, about $3 / 4$ in. long, and tipped with a soft prickle. Flowers in a terminal cluster, yellowish-purple, very showy. Pod linear, I-2 in. long, hairy. Maine to Florida, and westward. June. Fig. 595.

596. Leaflets 3. (Pea Family continued.)

Terminal leaflet distinctly longer stalked than the two side

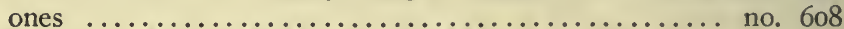

Leaflets all approximately equally stalked

Leaflets without teeth ................ Wild Indigo no. 597

Leaflets minutely but distinctly toothed

Flowers in loose spikes or close heads; pods curved or spirally twisted ............ Alfalfa and Medic no. 598

Flowers in long racemes, white or yellow; plants 3-10 ft. tall ......................... Melilot no. 6or

Flowers in dense, usually spherical clusters; plants 3-20 in. tall ........................ Clover no. 602

597. Wild Indigo. Baptisia tinctoria. A fleshy-stemmed perennial, very deeply rooted, with bluish-green foliage when young, quite smooth; much branched and dome-shaped by autumn, 2-4 ft. high. Leaflets 3 , without teeth, broadest towards the tip, about $3 / 4$ in. long. Flowers yellow, in fewflowered racemes, but numerous, and about $1 / 2$ in. long. Pod oval or nearly spherical, long-tipped. Whole plant turns black when dry. In dry soil. Ontario and Maine to Florida, and westward. July. Fig. 597.

598. MEDIC AND ALFALFA. MEDICAGO.

Low herbs with compound leaves and 3 minutely, but 

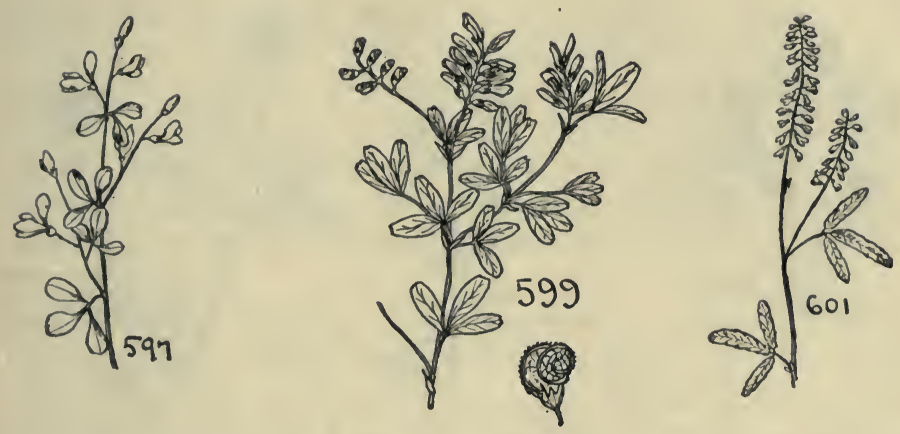

distinctly toothed leaflets, all approximately evenly stalked. Flowers in a loose terminal raceme, violet blue in alfalfa, and in a dense head-like cluster and yellow in the Medic. Pods curved or spirally twisted. Our two species, both European, are:

Flowers violet blue, pods hairy ............. Alfalfa no. 599

Flowers yellow; pods practically without hairs.......Medic no. 600 599. Alfalfa. Medicago sativa. A perennial, branched, more or less sprawling herb $\mathrm{I}-\mathrm{I} \mathrm{I} / 2 \mathrm{ft}$. high. Leaflets 3 , oblongoval, but broadest towards the tip, minutely toothed. Flowers in a loose, terminal raceme, violet-blue. Pods hairy, coiled. In fields and roadsides. Ontario to Virginia, and westward, where it is much cultivated as a forage crop. August. Fig. 599.

6oo. Medic. Medicago lupulina. More or less prostrate, and more common than No. 599 in the east. Leaflets broader. Flowers yellow, in a close, clover-like, long-stalked head, that arises at the leaf insertions. Pod nearly hairless, black when ripe. Throughout the region.

6ог. Melilot. Mclilotus alba. A tall much branched herb, $3^{-10} \mathrm{ft}$. high with very fragrant white flowers, much visited by bees. Leaflets 3 , almost perfectly oblong, minutely toothed. Flowers in long, rather loose, numerous terminal racemes. Pods smooth and veiny. Throughout the region in fields and waste places. Native of Eurasia. June-October. Fig. 6o I. A near relative, $M$. officinalis, found in similar situations has yellow flowers. 

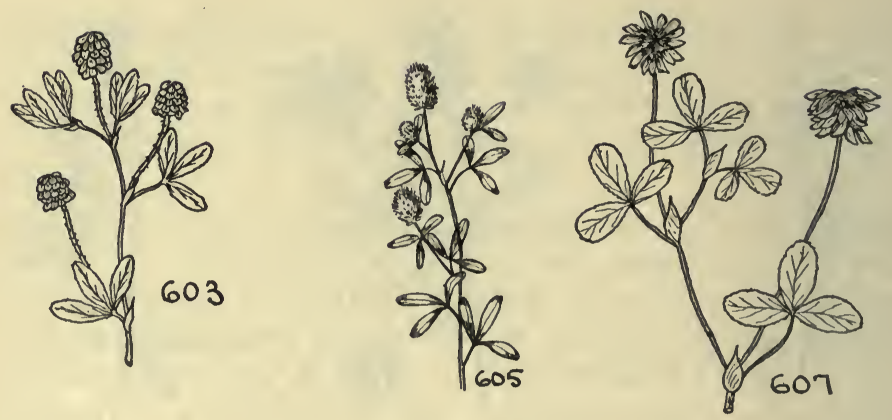

602. CLOVER. TRIFOLIUM.

A large genus, with over 12 species in our area, of prostrate or erect herbs with compound leaves and 3 leaflets that are approximately evenly stalked, and minutely but distinctly toothed. Flowers in clense head-like clusters, yellow, red, purple, or white, the cluster sometimes stalked, or more often stalkless or very short stalked. Pods small, often hidden by the sepals. All the species below are European, and most are cultivated. They are found along roadsides, or in fields rarely in the woods.

Flowers yellow ................... Yellow Clover no. 603 Flowers reddish or white

Flowers white or whitish

Nearly prostrate; flower cluster long stalked ............ White Clover no. 604 Erect, 6-18 in. high; flower cluster short stalked ........... ........................... Old-field Clover no. 605

Flowers red or pink

Flower clusters almost stalkless .......... Red Clover no. 606

Flower clusters long stalked .......... Alsike Clover no. 607 603. Yellow Clover. Trifolium agrarium. An erect clover, usually branched, and 6-15 in. high. Leaflets oblong, or ovaloblong, practically stalkless, slightly notched at the tip, wedge-shaped at the base. Flower cluster yellow, oblong, about $5 / 8$ in. long, on stalks $1 / 2-2$ in. long. Nova Scotia to So. Carolina, and westward. May-September. Fig. 603. A related species, $T$. procumbens, has shorter flower clusters, and its 
leaflets, especially the middle one, distinctly stalked. It is found from Nova Scotia to Georgia, and westward.

604. White Clover. Trifolium repens. A prostrate, creeping clover, very common in lawns. Leaflets roundish or oval, slightly but shallowly notched at the tip, about $1 / 2$ in. long. Flower clusters solitary on long stalks, usually overtopping the leaves, white. Throughout North America. May-November.

605. Old-Field Clover. Trifolium arvense. An erect clover, 6-18 in. high. Leaflets linear or linear-oblong, $1 / 2-1$ in. long, wedge-shaped at the base, stalkless and smooth. Flower clusters whitish, oblong, terminal, the stalk scarcely exceeding the cluster. Quebec and Ontario to Florida, and westward. May-Sept. Fig. 605.

606. Red Clover. Trifolium pratense. Resembling No. 605, but the flower clusters essentially stalkless, almost globe-like, and the flowers red. The leaflets are also hairy on the margins. One of the commonest clovers, nearly throughout North America, and much cultivated for fodder. May-October.

607. Alsike Clover. Trifolium hybridum. A stout, usually branched herb, I-2 ft. high. Leaflets smooth, oval, or roundish, about $3 / 4$ in. long, wedge-shaped at the base. Flowers pink, the cluster rather loose, its stalk many times exceeding the cluster in length. Nearly throughout North America. May-October. Fig. 607.

6o8. Terminal leaflet distinctly longer stalked than the two side ones. (Pea Family concluded.)

Flowers yellow ................... Pencil-flower no. 609

Flowers purple, blue or white.

Pods conspicuously several-jointed ...... Tick-trefoil no. 6ro

Pods inconspicuously 1 or 2-jointed ..... Bush-clover no. 617 6og. Pencil-flower. Stylosanthes biflora. A wiry branched, often hairy, and usually half prostrate herb, 6-20 in. long. Leaflets 3 , the terminal one stalked, the side ones stalkless, narrowly oblong, sharp pointed at the tip, $1 / 2-1 / 1 / 4$ in. long. Flowers few, yellow, about $1 / 4$ in. long, in sparse terminal 

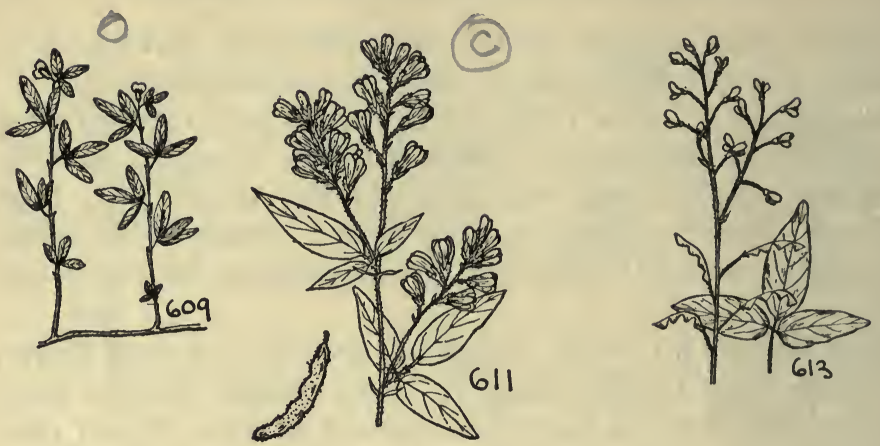

clusters. Pod nearly round, hairy. In dry places. Long Island, N. Y. to Florida and westward. July. Fig. 609.

6ro. TICK-TREFOIL. MEIBOMIA. (DESMODIUM.)

Perennial herbs, mostly of dry woods, but one in moist places; often somewhat woody at the base. Leaves compound, the 3 leaflets with the middle one conspicuously longer stalked that the two side ones. Flowers in open, often branched clusters, small, mostly purplish in those below. Fruit a jointed pod, the joints somewhat numerous, readily separable, and difficult to remove from clothing. Sometimes this pod is stalked, sometimes not; and the jointed pod is constricted only below or above and below. There are over 20 species, somewhat difficult to identify. The six here included may be separated thus :

Leaflets of an oblong type

Flowers very numerous; pods not stalked

Flowers not numerous; pods stalked

Showy Tick-trefoil no. 611

Plant usually smooth .............. Tick-trefoil no. 612

Plant usually hairy $\ldots \ldots \ldots \ldots \ldots \ldots$ Tick-trefoil no. $6 \mathbf{I}_{3}$

Leaflets of an oval type

Flower cluster at end of a stalk arising from the ground ....... Tick-trefoil no. 614

Flower cluster on a stalk arising from the stem of the plant

Erect; leaves mostly at the top of the stem ................

Reclining; leaves scattered...... Trailing Tick-trefoil no. 616 
6II. Showy Tick-trefoll. Meibomia canadensis. An erect, stout, hairy herb, $2-6 \mathrm{ft}$. high. Leaflets oblong, $2-3$ in. long. Flowers about $1 / 2$ in. long, in dense, terminal, very numerous clusters, purple or bluish-purple. Pods about $\mathrm{I}$ in. long, jointed, hairy, not stalked. In moist places. Nova Scotia to No. Carolina, and westward. August. Fig. 6i I.

6r2. Tick-trefoil. Meibonia paniculata. Plant more or less smooth, erect, slender, $2-4 \mathrm{ft}$. high. Leaflets oblong, $\mathrm{I}-2 \mathrm{in}$. long, the central one longer than those each side of it. Flowers about $1 / 4$ in. long, few, in an open lax cluster, purple. Pod I in. long, shortly stalked. In dry woods. Ontario and Maine to Florida, and westward. August.

6r3. Tick-trefoll. Mcibomia Dillenii. Plant usually hairy, erect, $2-3 \mathrm{ft}$. high. Foliage, flowers and fruit resembling No. 612, but the leaflets about twice as wide. In dry woods. Ontario and Maine to Alabama, and westward. August. Fig. 613.

6i4. Tick-TREFoll. Meibomia mudiflora. Erect or ascending, the leaves mostly at the top of the flowerless stems. Leaflets oval, I-3 in. long, pale on the under side. Flowers rosepurple, about $1 / 3$ in. long, clustered at the top of a naked, stalk that arises from the ground. Pods jointed, very long stalked. In dry woods. Quebec to Florida, and westward. August.

6I5. Beggar-ticks. Mcibomia grandiflora. Unlike all the other tick-trefoils in that the leaves are clustered at the top of the stem and from them the stalk of the flower cluster arises. Leaflets oval or nearly round, pointed, 2-6 in. long, hairy, the middle leaflet larger than the side ones. Flowers about $1 / 2$ in. long, in a loose cluster. Pod deeply jointed and long stalked. In dry woods. Quebec and Ontario to Florida, and westward. July.

6i6. Trailing Tick-trefoll. Mcibomia Michauxii. More or less decumbent or prostrate, $2-6 \mathrm{ft}$. long, hairy. Leaflets nearly round, $\mathrm{I}-\mathrm{I} 1 / 2 \mathrm{in}$. long. Flowers about $1 / 3 \mathrm{in}$. long, purple, in a loose open cluster. Pod short stalked. In dry woods. Ontario to Florida, and westward. August. Fig. 616. 

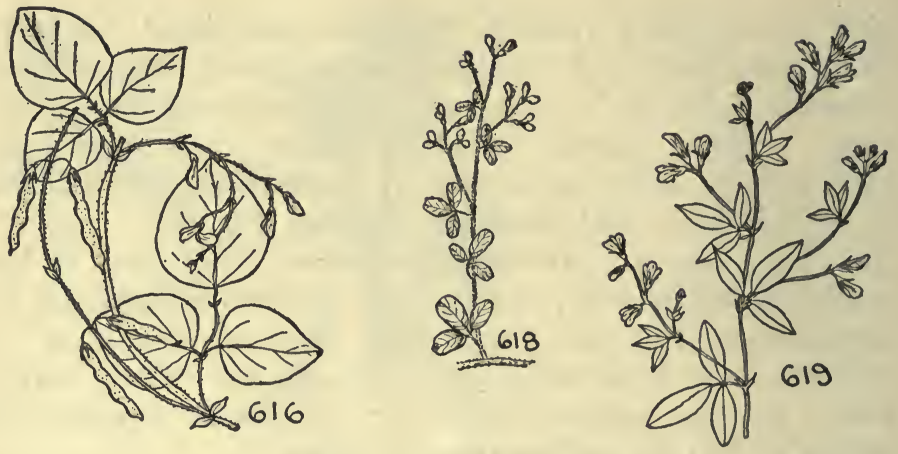

\section{6r 7. BUSH-CLOVER. LESPEDEZA.}

A difficult group of plants to identify; erect or trailing, with compound leaves, and 3 leaflets, the central leaflet always longer stalked than the side ones. Flowers of two sorts, one with petals and mostly sterile, the other without petals, but setting fruit, and these are often intermixed. Flowers few in sparse clusters, or in dense head-like clusters. Fruit a small jointed pod, the joints not obvious as in the Ticktrefoils. Of the dozen species known in the area, the four following are typical of the most widely known:

Stems prostrate, almost vine-like....Trailing Bush-clover no. 618 Stems erect, often stiff, and partly woody

Flowers purplish

Flower cluster open, its stalks exceeding the leaves ..... $\ldots \ldots \ldots \ldots \ldots \ldots \ldots \ldots \ldots$ Bush-clover no. 6ra

Flower cluster contracted, its stalks shorter than the leaves .............................. Bush-clover no. 620 Flowers whitish, in dense clusters ...... Dusty-clover no. 62I 6i8. Trailing Bush-clover. Lespedeza procumbons. A trailing hairy vine-like herb, $\mathrm{I}-3 \mathrm{ft}$. long, with ascending branches usually about 6 in. high. Leaflets oval, about $3 / 4$ in. long. Flowers purple, about $1 / 2$ in. long, in a long-stalked loose, few-flowered cluster. Pods hairy, nearly round, about $1 / 8$ in. in diameter. In dry places. New Hampshire to Florida, and westward. August. Fig. 618. A close relative, L. repens, dif- 

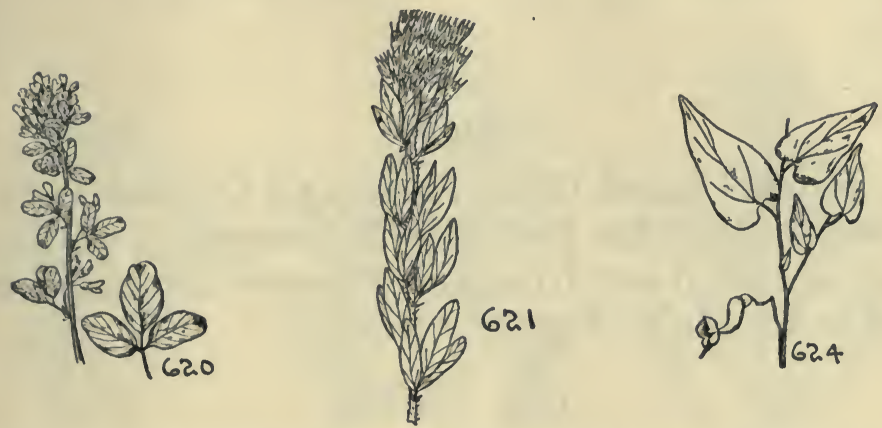

fers in being mostly without hairs, and is found from Conn. to Florida, and westward.

6rg. Bush-Clover. Lespedeza violacea. Erect, branched, I-3 $\mathrm{ft}$. high. Leaves rather few, the leaflets oblong, pointed both ends, $3 / 4-I \frac{1}{4}$ in. long. Flowers violet-purple, in an open longstalked cluster, much exceeding the leaves. Pod oval, about $1 / 4$ in. long, slightly hairy. In dry places. New Hampshire to Florida, and westward. August. Fig. 6rg.

620. Bush-clover. Lespedeza frutescens. An erect herb, branched or not, $\mathrm{I}-3 \mathrm{ft}$. high. Leaves numerous, the leaflets oval or oblong, $1 / 2-11 / 2$ in. long, smooth above, pale and hairy beneath. Flowers violet-purple, about $1 / 4$ in. long, in a close, more or less contracted cluster, so short stalked it does not exceed the leaves. Pod oval-oblong, pointed, hairy, about $1 / 8$ in. long. In dry places. Maine and Ontario to Florida, and westward. August. Fig. 620. There are several closely related species, all perhaps hybridizing.

621. Dusty-ClOVER. Lespedea capitata. Usually unbranched and wand-like, stiff, silvery-hairy, 2-4 ft. high. Leaflets oblong or linear-oblong, $I-I \frac{1}{2}$ in. long, hairy on the margins, pointed at both ends. Flowers whitish or yellowish-white, purple dotted, in a dense oblong, or globe-shaped, shortstalked cluster, mostly at the tips of the branches. Pods ovaloblong, hairy, very small. In dry open places. Ontario and Maine to Florida. August. Fig. 62 I. There are several closely related species, differing in the amount and kind of hairiness, and the width of the leaflets. 
No. 622

\section{Petals United, Often Forming a Distinct Tube, Which May Be Perfectly Symmetrical, or Un- symmetrical and Irregular. Flowers not in Heads as in the Daisy Family, No. 809.}

(Nos. 623-808.)

There are about 200 species in this group of plants. In all of them the petals are united to form a tube of some sort which may be regular and cylindrical or bell-shaped. In others, the flower may be very irregular and unsymmetrical, often I-sided, and with an obvious lip. Whether regular or irregular, these united petals are known as a corolla, and this term will be used throughout this section of the book. The main divisions are:

Leaves none, or wanting at flowering time and rarely seen, or reduced to tiny scales $\ldots \ldots \ldots \ldots \ldots \ldots \ldots \ldots \ldots$ no. 802 Leaves obvious

Leaves wholly basal $\ldots \ldots \ldots \ldots \ldots \ldots \ldots \ldots \ldots$ no. 798 Leaves mostly on the stem, sometimes a few basal ones

Leaves opposite, or clustered, or crowded, never alternate ( 2 exceptions, noted) $\ldots \ldots \ldots \ldots \ldots \ldots \ldots \ldots \ldots \ldots$ no. 670 Leaves always alternate (exception noted at) ....... no. 623

623. Leaves always alternate, except in the Lousewort, No. 627. (Nos. 624-669.)

Corolla regular and symmetrical, not I-sided ........ no. 634 Corolla irregular and unsymmetrical, often I-sided, or 2-lipped (see Figs. 624-632)

Flower bent and S-shaped, arising directly from the ground Flowers not so

Flower cluster conspicuously I-sided..... Blue-weed no. 625 Flower clusters not I-sided

Stem leaves more or less deeply cut

Upper leaves 3-lobed, those near the flowers brilliant scarlet $\ldots \ldots \ldots \ldots \ldots \ldots \ldots$. Painted-cup no. 626 Upper leaves not 3-lobed, but cut into many segments; 

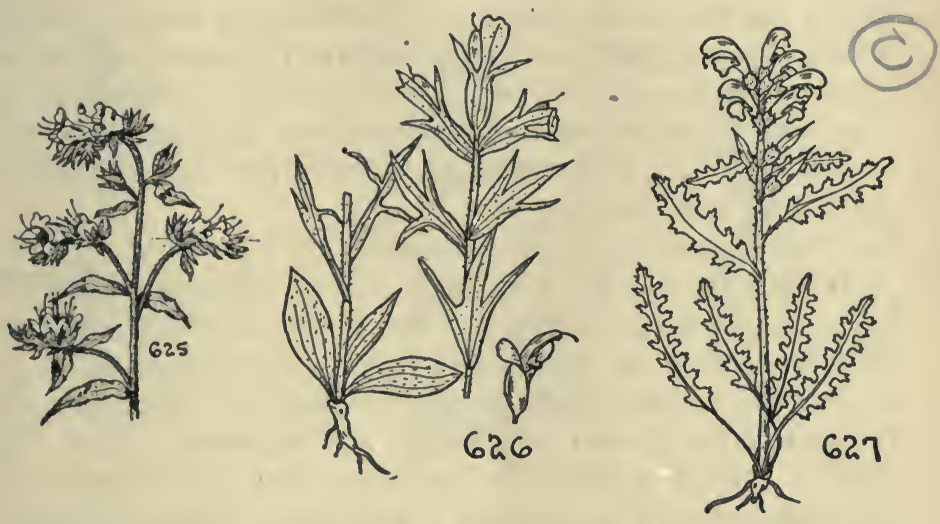

not scarlet ................ Lousewort no. 627 Stem leaves not cut; toothed or not $\ldots \ldots \ldots \ldots \ldots \ldots$ .............. Cardinal-flower and Lobelias no. 628 624. Virginia Snakeroot. Aristolochia Serpentaria. (Aristolochiaccac.) A hairy woods perennial, I-3 ft. high with aromatic roots. Leaves alternate, stalked, heart-shaped at the base, oval or lance-shaped, pointed at the tip, 2-4 in. long. Flowers solitary on a scaly stalk arising from the ground. Petals none, but the united sepals (calyx) greenishpurple and corolla-like, bent S-shaped, about 2 in. long. Conn. to Florida, and southward. June. Fig. 624. See also No 800. 625. Blue-WeEd. Viper's Bugloss. Echium vulgare. (Boraginaccac.) A biennial European weed, I-2 ft. high, covered with bristly hairs. Leaves oblong or oblong-linear, 2-6 in long, toothless, alternate, essentially stalkless. Flowers irregular and unsymmetrical, but not 2-lipped, about $I$ in. long, in terminal I-sided clusters, blue, but the buds pink. In fields and waste places. Nova Scotia to No. Carolina, and westward. July. Fig. 625. For other plants in this family see No. 635 .

626. Painted-cup. Castilleja coccinea (Scrophulariaceae.) A brilliantly colored soft-hairy, parasitic annual or biennial, I-2 $\mathrm{ft}$. high, and usually unbranched. Basal leaves oblong lanceshaped, parallel-veined, I-3 in. long. Stem leaves alternate, deeply cut into 3 wedge-shaped lobes, growing smaller to- 
wards the top of the plant and there bright scarlet, among which the irregular and unsymmetrical flowers are borne. Sepals united, scarlet. Corolla greenish-yellow, 2-lipped, about $I$ in. long. In moist meadows and prairies. Maine and Ontario to No. Carolina, and westward, usually rare near the coast. June. Fig. 626. See No. 781.

627. Lousewort. Pedicularis canadensis. (Scrophulariaceae.) A hairy perennial 8-I 5 in. high. Leaves alternate, lance-oblong, 3-5 in. long, deeply cut into many, toothed, segments. Flowers yellow or yellow-red, strongly 2-lipped, about $3 / 4$ in. long, in a dense leafy terminal cluster. In dry woods and thickets. Nova Scotia to Florida, and westward. May. Fig. 627. A related species, $P$. lanccolata, has more deeply cut leaves and usually lacks hairs. It grows in wet places. Ontario and New England to No. Carolina, and westward. August.September. See No. 78I.

\section{CARDINAL-FLOWER AND LOBELIAS. LOBELIA.}

Leafy-stemmed herbs with alternate, unlobed leaves, which may be toothed or not. Flowers in clusters, usually in terminal racemes. Corolla irregular, divided to the base and conspicuously 2-lipped, the three lower lobes larger than the two upper ones. (Lobcliaceac.) See No. 945 for the aquatic Water Lobelia.

Corolla $3 / 4-1$ in. long

Corolla scarlet, about $I$ in. long........ Cardinal-flower no. 629

Corolla blue, or blue and white about $3 / 4$ in. long ...........

Corolla about $1 / 4$ in. long

Stems mostly unbranched ............ Pale Lobelia no. 63I

Stems branched

Hairy; leaves oval or lance-oval..... Indian Tobacco no. 632

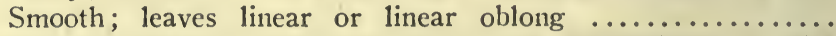

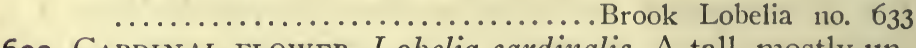
629. CARDINAL-FLOWER. Lobclia cardinalis. A tall, mostly unbranched perennial of moist shady places, $2-5 \mathrm{ft}$. high, with alternate, lance-oval, minutely toothed leaves, pointed both 

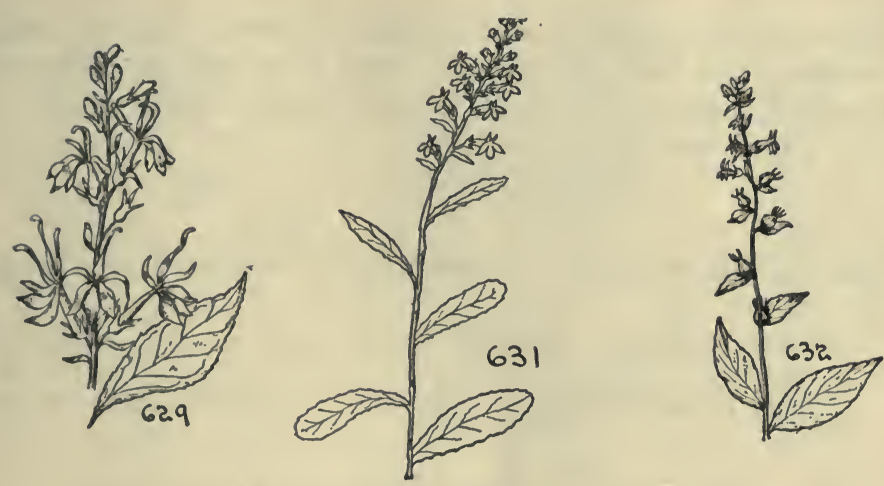

ends and $3-5$ in. long. Flowers $I-1 / 2$ in. long, scarlet, very showy, in terminal, usually numerous racemes. New Brunswick to Florida, and westward. August. Fig. 629.

630. Great Lobelia. Lobelia syphilitica. Shorter than No. 629 , and with smaller, blue or blue and white flowers. In moist places. Maine and Ontario to Georgia and westward. August. A still lower plant, L. puberula, is covered with slightly sticky hairs and is found in moist sandy places from southern New Jersey to Florida, and westward.

631. Pale Lobelia. Lobelia spicata. An erect, wand-like, unbranched perennial, I $1 / 2-3 \mathrm{ft}$. high. Leaves, at least the upper ones, stalkless, oblong or lance-oblong. $\mathrm{I}^{\mathrm{x} / 2-3}$ in. long, slightly wavy-margined. Flowers pale blue, about $1 / 4 \mathrm{in}$. long, in a dense terminal elongated cluster that may be $\mathrm{I} \mathrm{ft}$. long. In dry places. Nova Scotia to No. Carolina, and westward. July. Fig. 63r.

632. Indian Tobacco. Lobelia inflata. An annual, almost weedy, much branched and densely hairy plant, I-3 ft. high. Leaves essentially stalkless, oval or lance-oval, $1 \frac{1}{2}-2$ in. long, minutely toothed. Flowers about $1 / 4$ in. long, blue, in numerous, but not dense flower clusters. Fruit a much enlarged, veiny pod, about $1 / 4$ in. long. In dry fields and thickets. Labrador to Georgia and westward. July-October. Fig. 632. 633. Вrook Lobelia. Lobelia Kalmii. A smooth, usually branched, slender perennial 6-15 in. high. Leaves linear or 
linear-oblong, minutely and distantly toothed, $1 / 2-1$ in. long. Flowers light blue, about $1 / 4$ in. long, in loose, few flowered, terminal clusters. In moist or wet places. Nova Scotia to N. J., and westward. August.

634. Corolla regular and symmetrical, or very nearly so, not I-sided.

Flower cluster not distinctly I-sided (see no. 662 for an ex-

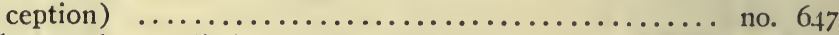
Flower cluster distinctly I-sided ....... Borage Family no. 635

635. BORAGE FAMILY. BORAGINACEAE.

A family of herbs (shrubs or trees in the tropics) almost unique in having the foliage hairy throughout, except in the Virginia Cowslip, No. 636. Leaves always alternate in those below, mostly without teeth. Corolla tubular or at least united, symmetrical, not I-sided, but nearly always borne in curving, I-sided clusters. Fruit consisting of four I-seeded nutlets, often enclosed in a sticky bur. See also No. 625. Those below may be separated thus:

Some, or all the leaves, at least $3 / 4$ in. wide, usually more.

Corolla tube obvious, at least half the length of the flower.

Flowers blue ................ Virginia Cowslip no. 636

Flowers yellowish-purple .............. Comfrey no. 637

Corolla tube short, usually less than $1 / 3$ the length of the flower

Leaves without a distinct marginal vein

Flowers reddish-purple .......... Hound's-tongue no. 638

Flowers blue ................. Wild Comfrey no. 639

Leaves with a distinct marginal vein...... Stick-tight no. 640 Leaves $1 / 2$ in. wide, or less

Flowers blue

Leaves linear-oblong $\ldots \ldots \ldots \ldots \ldots \ldots \ldots$ Burseed no. $64 \mathrm{I}$

Leaves oval-oblong ............... Forget-me-not no. 642 Flowers white

Flower cluster not leafy ..... Spring Scorpion-grass no. 643 Flower cluster leafy .............. Corn Gromwell no. 644

Flowers yellow-orange or yellowish-white

Corolla tube short, usually less than $1 / 3$ the length of the

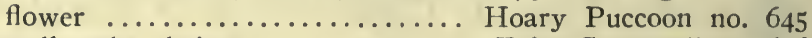
Corolla tube obvious .............. False Gromwell no. 646 

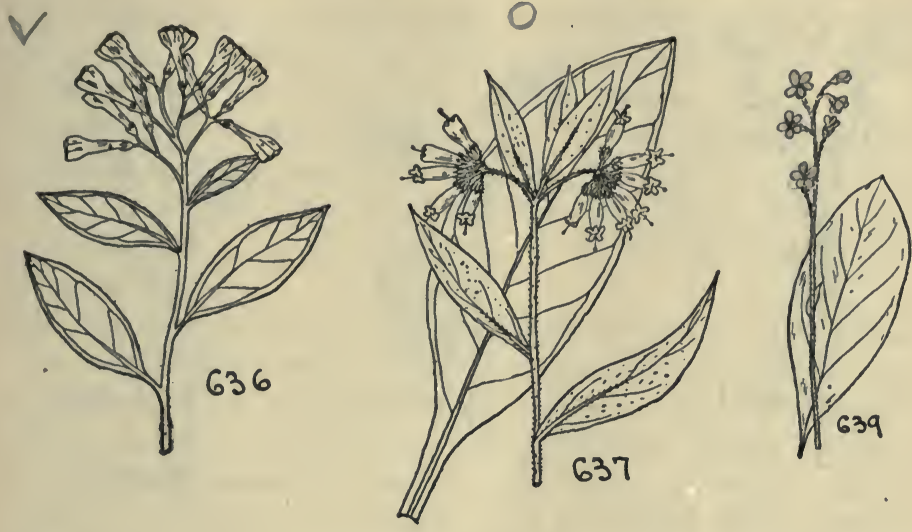

636. Virginia Cowslip. Mertensia virginica. A smooth, erect, usually unbranched, herb I-2 ft. high. Leaves oblong or oval-oblong, stalked $2-5$ in. long, about $\mathrm{I}^{\mathrm{L}} / 2 \mathrm{in}$. wide, and with a distinct marginal vein about $1 / 16$ in. from the leafedge. Flowers purplish-blue, very showy, about $\mathrm{I}$ in. long, the tube narrow, and at least half the total length of the flower. In wet places. Southern Ontario to So. Carolina, and westward. Locally often rare. April. Fig. 636.

637. Comfrey. Symphytum officinale. A Eurasian weed, 2-3 ft. high, with an erect branched stem. Basal leaves $3^{-10}$ in. long, oval or lance-oval, with a distinct marginal vein, about $1 / 16$ in. from the leaf-edge, the upper leaves smaller, and without the marginal vein. Flowers in a terminal, only slightly I-sided cluster, yellowish-purple, the tube more than $3 / 4$ the total length of the flower, which is about $3 / 4$ in. long. In waste places, Newfoundland to Virginia and No. Carolina. July. Fig. 637.

638. Hound's-tongue. Cynoglossum officinale. An erect leafy European biennial weed, I-3 ft. high. Basal leaves oblong, long-stalked, 6-I 2 in. long, I-3 in. wide, the upper ones smaller and narrower. Flowers reddish-purple, about $1 / 4$ in. long, in a long curving raceme, which is much elongated in fruit. In fields and waste places. Quebec and Ontario to So. Carolina, and westward. June-Septemher. 

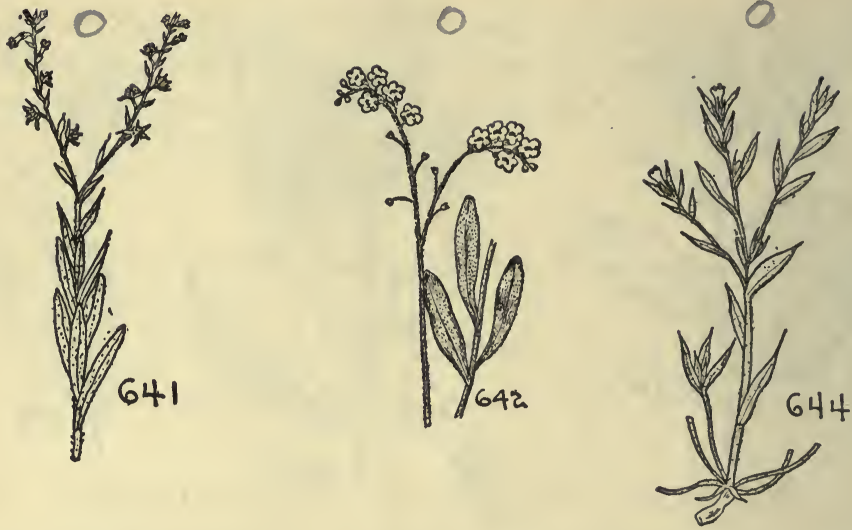

639. Wild Comfrey. Cynoglossum virginianum. A native relative of No. 637, with larger stem leaves, and broader basal ones. Flowers blue, in long-stalked rather open, slightly I-sided, racemes. In woods. N. J. to Florida, and westward. Fig. 639.

640. Stick-тight. Lappula virginiana. A much branched biennial 2-4 ft. high. Basal leaves oval or nearly round, 3-8 in. long, $\mathrm{I} / 4-3$ in. wide, with a distinct marginal vein, the upper leaves smaller. Flowers small, white, scarcely $1 / 4$ in. long, in a loose interrupted and few-flowered cluster, which is only slightly I-sided. Fruit a sticky bur enclosing the nutlets. In dry woods and thickets. New Brunswick to Georgia, and westward. June-September.

641. Burseed. Lappula Lappula. (Lappula echinata.) A pale European weed, I-2 ft. high with narrowly linear leaves, less than $1 / 2$ in. wide. Flowers as in No. 640 , but blue. In waste places. Nova Scotia to New Jersey, and westward. MaySeptember. Fig. 64I.

642. Forget-ME-NOT. Myosotis scorpioides. A semi-erect hairy European perennial, usually rooting at the lower joints. Leaves of an oval-oblong type, I-3 in. long, a little less than $1 / 2$ in. wide. Flowers about $1 / 3$ in. wide, the tube very short, blue with a yellow center, in terminal obviously I-sided racemes. In wet places. Newfoundland to Tenn., as an escape 
from cultivation. June. Fig. 642. A related native species, $M$. laxa, with a similar range and growing also in wet places differs mostly in having still smaller flowers.

643. SPRING SCORPION-Grass. Myosotis virginica. An erect, hairy, branched plant of dry places, 5-12 in. high. Leaves and flowers very like No. 642, but the flowers white, and scarcely $1 / 8$ in. wide. Ontario and Maine to Florida, and westward. May.

644. Corn Gromwell. Lithospermum arvense. A European, mostly branched weed, 8-18 in. high, and hairy. Leaves linear or linear oblong, stalkless, rather pointed at the tip. Flowers white, about $1 / 4$ in. long, obviously tubular, almost stalkless in leafy few-flowered clusters. In fields and waste places. Quebec and Ontario to Georgia and westward. May-August. Fig. 644. A related plant, L. officinale, the European Gromwell, is twice as tall, has broader leaves and very similar flowers. It grows in waste places and fields from Quebec to New Jersey, and westward.

645. Hoary Puccoon. Lithospermum canescens. A stiffhairy, somewhat ashy-colored perennial, 8-I 5 in. high. Leaves very like No. 644, but the flowers about twice as large, orange yellow, with a short tube, and in leafy clusters. In dry places. Ontario to western New Jersey, south to Alabama and westward. May.

646. False Grom well. Onosmodium virginianum. A densely hairy, usually branched herb, I-2 ft. high. Leaves oval-oblong, rounded at the tip, I-3 in. long, about half as wide, narrowed into short stalks. Flowers yellowish-white, with an obvious tube, hairy on the outside, and arranged in terminal, very I-sided, more or less leafy racemes or spikes. In dry places. Mass. to Florida, westward along the Gulf to Louisiana. June. Fig. 646.

647. Flower cluster not distinctly I-sided. (See No. 662 for an exception.).

Plants prostrate, more or less woody; leaves evergreen .. no. 667 

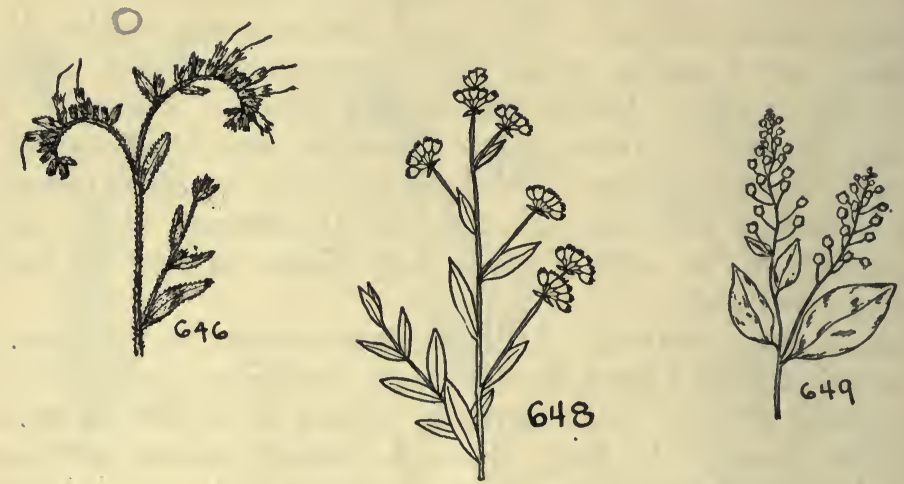

Plants mostly erect, if low not woody; leaves not evergreen Leaves compound ....................... no. 664 Leaves not compound

Flowers blue, lilac, or bluish-white ..... Bellflower no. 658 Flowers yellow, yellowish-white, or white

Plants $1 \frac{1 / 2-4}{\mathrm{ft}}$. high

Flowers in terminal spikes or racemes. . Mullein no. 655 Flowers not in terminal spikes or racemes ..........

Plants 6-12 in. high; flowers pure white

Leaves oblong; in dry places. . Bastard Toad-flax no. 648 Leaves oval; in wet places, often in salt marshes .... ................... Water Pimpernel no. 649 648. Bastard Tonf-Flax. Comandra umbellata. (Santalaccac.) An erect, wiry, usually branched herb, 6-I2 in. high, with alternate, oblong, stalkless, toothless, bright green leaves, $1 / 2-1 / 4$ in. long. Flowers white in terminal bunched clusters. Petals none, but the sepals united, petal-like. Fruit small, dry, crowned by the withered but persistent flower. In dry sandy places. Nova Scotia and Ontario to Georgia, and westward. June. Fig. 648. The plant is partially or wholly parasitic. There are two other closely related species, $C$. pallida with pale bluish-green foliage, and $C$. livida, which is usually unbranched.

649. Water Pimpernel. Samolus floribundus. (Primulaceac.) An erect, mostly branched, smooth herb 6-I2 in. high. Leaves oval, obviously stalked, toothless, I-3 in. long, about half as wide. Flowers about $1 / 8$ in. wide, white, in rather 

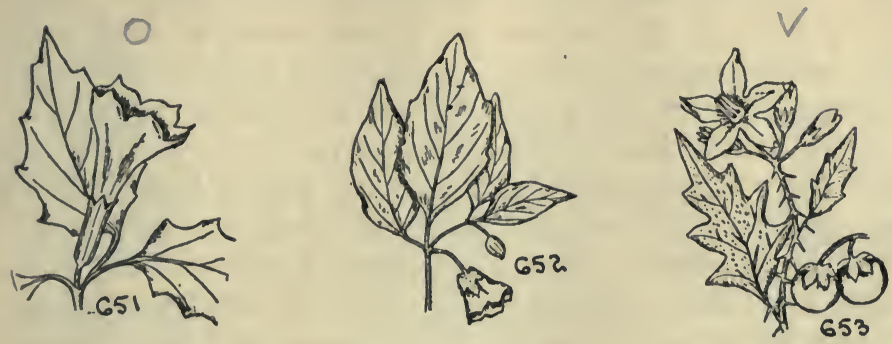

loose open racemes that may be terminal or from among the leaves, and are often branched. In wet places, often in salt marshes. New Brunswick to Florida and westward. MaySeptember. Fig. 649. See also Nos. 449 and 466.

\section{POTATO FAMILY. SOLANACEAE.}

An immense family of plants, including the potato, tomato, tobacco, egg-plant, and belladonna. Nearly all our species are herbs, but hundreds in the tropics are shrubs and trees. Leaves alternate. Corolla sometimes flat and open, or bellshaped or tubular. Fruit a berry or dry. Most of the few representatives of the family found in our region are tall stout herbs. They may be separated thus:

Flowers solitary or few, not in clusters

Flowers about 4 in. long ............. Jimson-weed no. 65x

Flowers about I in. long or less ........ Ground-cherry no. 652

Flowers in clusters

Leaves and stems prickly .............. Horse-nettle no. 653

Leaves and stems not prickly ....... Black Nightshade no. $65 t$ 651. Jimson-WEed. Datura Stramonium. A stout European weed, $1 \mathrm{I} / 2-5 \mathrm{ft}$. tall, with a green or purple stem and large coarsely angled stalked leaves, 3-8 in. long. Flower solitary, about $4 \mathrm{in}$. high, the long tube flaring at the top, white, or rarely violet. Fruit a prickly bur, about $2 \mathrm{in.} \mathrm{long}$ and half as thick. The juice of this plant is poisonous. In fields and waste places. Nova Scotia to Florida, and westward. June-September. Fig. 651 .

652. Ground-cherry. Physalis virginiana, A branched herb, 
I $1 / 2-3 \mathrm{ft}$. high, the lance-oval, almost unangled and toothless, stalked leaves, $\mathrm{I} / 2-2 \mathrm{r} / 2$ in. long, and more or less hairy. Flowers few or often solitary, not in clusters, about $I$ in. long or a little less, yellow, with purple spots. Fruit a reddish berry, surrounded by a swollen, angled husk. In rich soil. Ontario to Florida, and westward. August. Fig. 652. Related species are $P$. heterophylla, with a yellow berry, hairy husk, and sticky foliage, which grows in similar situations; and the Strawberry Tomato, $P$. peruviana, with long pointed, hairy, but not sticky, leaves, sometimes escapes from cultivation.

653. Horse-nettle. Solanum carolinense. An erect, hairy; branched herb, I I/2-3 ft. high, the stems covered with weak yellow prickles, a few of which are found also on the principal veins of the leaves. Leaves more or less deeply cut or lobed, stalked, 2-6 in. long. Flowers in small, loose, apparently terminal clusters, yellow, about $3 / 4$ in. wide. Berries orange-yellow, about $3 / 4$ in. in diameter. In fields and waste places, mostly as a weed. Ontario to Florida, and westward. May-September. Fig. 653.

654. Black Nightsiade. Solanum nigrum. A variable, erect weed, $I \frac{1}{2}-2^{1} / 2 \mathrm{ft}$. high, always branched, and without prickles. Leaves without teeth, or angles, or occasionally somewhat angled, oval, stalked, $\mathrm{I}-3$ in. long. Flowers white, in few-flowered clusters from among the leaves. The pointed lobes of the corolla recurved. Berry smooth, about $1 / 3$ in. in diameter, black when ripe. In waste places. Nova Scotia to Florida, and westward. July-October. Fig. 654. See also No. 203.

\section{MULLEIN. VERBASCUM.}

Mostly biennial erect herbs, our species $\mathrm{I} / 2-7 \mathrm{ft}$. Leaves alternate, toothed or merely wavy-margined. Flowers in long erect, terminal spikes or racemes. Corolla tube not very obvious, its lobes spreading and rounded. Fruit a smooth dry pod. (Scrophulariaceac.) See No. 78I for description of this family. Our two species are: 

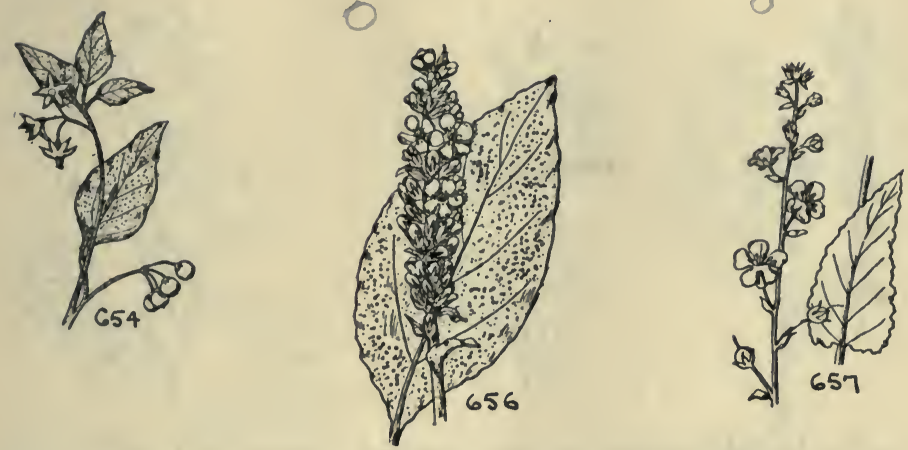

Leaves white-woolly, $4-8$ in. long ....... Great Mullein no. 656 Leaves not white-woolly, I-2 in. long ..... Moth Mullein no. 657 656. Great Mullein. Verbascum Thapsus. A coarse, pasture, Eurasian weed, found also in waste places, $2-7 \mathrm{ft}$. high, with a rosette of large leaves and smaller ones on the stem, the whole plant white-woolly. Leaves nearly stalkless, oval, pointed both ends, 4-8 in. long. Flowers yellow, about $3 / 4$ in. long, in a long terminal dense spike which is often $1 \mathrm{I} / 2$ in. thick. Almost throughout North America. June-September. Fig. 656 .

657. Moth Mullein. Verbascum Blattaria. An erect, usually unbranched Eurasian herb, not white-woolly, I $1 / 2-31 / 2$ ft. high. Leaves distinctly toothed, long-triangular, nearly straight at the base, pointed at the tip, I-2 in. long, the basal ones much larger. Flowers yellowish-white, with brown marks on the outside, in a long terminal, rather sparse, raceme. In fields and waste places, throughout the United States. June-November. Fig. 657. A related species, V. Lychnites, has branched flower clusters and leaves narrowed at the base. It is Eurasian, and grows in fields and waste places. Ontario to New Jersey and Penn.

658. BELLFLOWER FAMILY. CAMPANULACEAE.

Beautifully flowered herbs with alternate leaves and usually a milky juice. Flowers usually showy, the corolla almost 

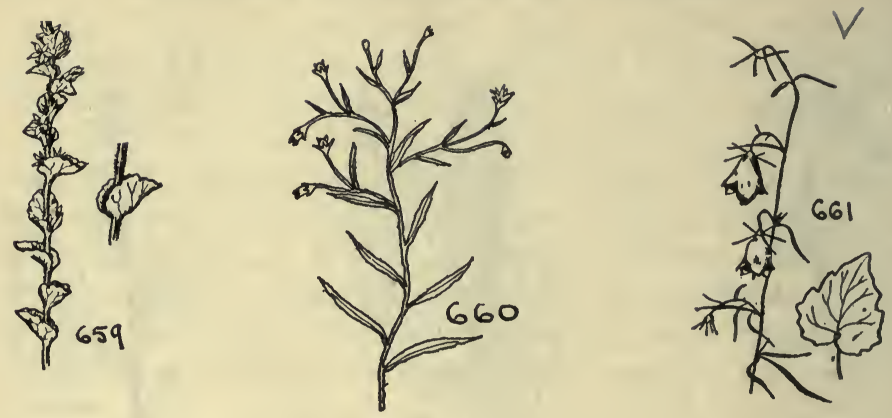

perfectly bell-shaped in most species, flatter and with a less obvious tube in the. Venus' Looking-glass, and in the Tall Bellflower. Fruit a dry, many-seeded pod.

Leaves stem-clasping, almost cup shaped..$\ldots \ldots \ldots \ldots \ldots \ldots$.

Leaves not stem-clasping

Flowers almost perfectly bell shaped.

Stem leaves narrowly linear

Flowers whitish, about $1 / 3$ in. long

........................ Marsh Bellflower no. 660

Flowers blue, about $3 / 4$ in. long ......... Harebell no. 66I

Stem leaves oval or lance-oval...European Bellflower no. 662

Flowers not bell shaped, in a dense leafy terminal cluster .....

659. Venus Looking-GLASS. Specularia perfoliata. A usually unbranched densely leafy herb, 6-20 in. high. Leaves stem-clasping, almost cup shaped, about $3 / 4$ in. wide. Flowers small, one or two from each leaf insertion, rather flat, the pointed lobes of the blue or violet corolla looking like separate petals. In dry places, Maine and Ontario to Florida, and westward. May-September. Fig. 659.

66o. Marsh Bellflower. Campanula aparinoides. A delicate weak perennial with very slender, half prostrate stems, and narrowly linear, rough margined leaves, $1 / 2-1 \mathrm{~T} / 2$ in. long. Flowers bell-shaped, few, in a sparse, leafy, open cluster, whitish, about $1 / 3$ in. long. In wet meadows. Maine to Georgia, and westward. July. Fig. 660.

661. Harebell. Campanula rotundifolia. An erect or some-

$\checkmark \sin 253$ 

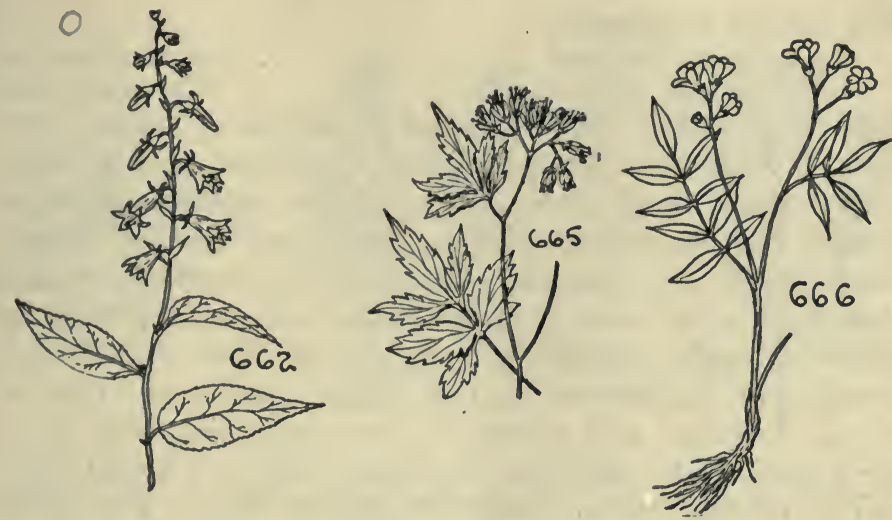

what sprawling perennial 6-20 in. high, with narrowly-linear, pointed stem leaves about $3 / 4$ in. long. Basal leaves round heart-shaped $1 / 2-I$ in. wide, long stalked, but mostly absent at flowering time. Flowers in a loose terminal raceme, or solitary, the corolla blue, perfectly bell-shaped, about $3 / 4$ in. long. On wet cliffs or in meadows. Labrador to Penn. and westward. Native also in Europe and Asia. June-September, Fig. 66 I.

662. European Bellflower. Campanula rapunculoides. An erect usually unbranched perennial, $\mathrm{I} / 2-3 \mathrm{ft}$. high. Leaves short-stalked, oval or lance-oval, finely toothed, 3-6 in. long, about half as wide. Flowers blue, in a long, distinctly I-sided raceme. Corolla perfectly bell-shaped, blue, about I in. long. In fields and along roadsides. New Brunswick and Ontario, Penn., west to Ohio. Often cultivated. August. Fig. 662.

663. Tall Bellflower. Campamula amcricana. A usually hairy, mostly unbranched herb $2-6 \mathrm{ft}$. high. Leaves oblong or lance-oblong, 3-6 in. long, slightly toothed, the lower stalked, the upper usually stalkless. Flowers in a long, terminal, leafy spike. Corolla flattish, the tube not very obvious, blue, or rarely whitish, about I in. wide. In moist woods. New Brunswick to Florida, and westward. Locally rare. August. 
664. Leaves compound.

Leaf segments toothed

Leaf segments not toothed ................ Water-leaf no. 665 665. WATER-LEAF. Hydrophyllum virginianum. (Hydrophyllaceae.) A weak, unbranched, leafy perennial, I-2 ft. high. Leaves alternate or basal, compound, the segments arranged feather-fashion, rather distinct, irregularly wedge shaped, often lobed, and coarsely toothed. Flowers white or pale lavender, rarely violet or darker, in a close, but few-flowered cluster. Corolla tubular or bell shaped. Fruit round, dry, about $1 / 8$ in. in diameter. In rich woods. Quebec and Ontario to So. Carolina, and westward. June-July. Fig. 665. A related species, $H$. canadense, has leaves with $5-9$ broad lobes, and occasionally one or two much smaller leaflets. It is found in rich woods. Vermont to No. Carolina, westward to Illinois and Kentucky, and is rare near the coast.

666. Blue-Bell. Polemonium reptans. (Polcmoniaceae.) A smooth, somewhat weak perennial, about I ft. high. Leaves compound, the oval leaflets very short stalked, toothless, arranged feather-fashion, about $3 / 4$ in. long. Flowers blue, in an open loose cluster. Corolla bell-shaped, cleft to about the middle, about $1 / 2$ in. wide, the lobes rounded. Fruit dry, the seeds mucilaginous. In woods. New York to Georgia, and westward. May. Fig. 666. A related species, P. Van Bruntiae, has larger, bluish-purple flowers. Mostly in the mountains. Vermont and northern New York to Maryland. See Nos. 679 and 727 .

667. Plants prostrate, more or less woody; leaves evergreen.

Leaves $11 / 2-3$ in. long ............ Trailing Arbutus no. 668

Leaves $1 / 2$ in. long or less ........ Creeping Snowberry no. 669 668. Trailing Arbutus. Mayflower. Epigaca repens. (Ericaceae.) A prostrate plant with rough, evergreen leaves and a woody stem. Leaves alternate, oblong or oblong-oval, thick and leathery, $\mathrm{I} / 2-3$ in. long, on obviously hairy stalks. Flowers tubular, pink or white, very fragrant, about $5 / 8 \mathrm{in}$. 

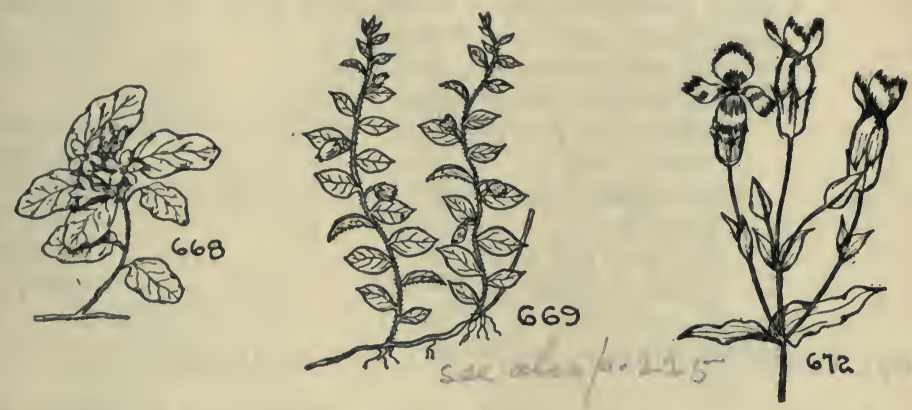

long, few, in a rather close cluster, half hidden by the foliage. Fruit a dry pod, with a fleshy white interior. In dry woods. Newfoundland to Florida, and westward. April. Fig. 668. See No. 726.

669. Creeping Snowberry. Chiogenes hispidula. (Vacciniaceae.) A creeping prostrate plant with a rough-hairy, very slender, woody stem. Leaves alternate, shining, oval, stalkless, evergreen, about $3 / 8$ in. long. Flowers solitary at the leaf joints, short-stalked, nodding. Corolla short bell-shaped, about $1 / 8$ in. long. Fruit a white berry, about $1 / 4$ in. in diameter. June. In cold woods, or in bogs. Newfoundland to No. Carolina, only in the uplands, and westward to northern Michigan and British Columbia. Often on Alpine summits. June. Fig. 669.

670. Leaves opposite, or clustered, or crowded, never alternate (except the upper leaves of the Purslane Speedwell, No. 793, and the Butterfly-weed, No. 697). Nos. 671-797.

Corolla decidedly unsymmetrical or distinctly 2 -lipped...no. 738 Corolla regular and symmetrical, not 2-lipped.

Leaves more than 2 at a joint, often several, sometimes crowded ............................. no. 725

Leaves truly opposite; (clustered in the Closed Gentian, no. 673, and in two Milkweeds, nos. 702 and 704).

Leaves lobed, or divided, or with obvious marginal teeth no. 708 
Leaves without marginal teeth, or if these are present, inconspicuous and very shallow

Plants with conspicuous milky juice .......... no. 695 Plants without milky juice

Prostrate or low plants, not usually over 8-10 in. high, mostly less ...................... no. 688

Erect plants, usually not over I $\mathrm{ft}$. high, sometimes much more so.

Flowers not blue ................. no. 677 Flowers bright or deep blue ........ Gentian no. 671

\section{GENTIAN. DASYSTEPHANA AND GENTIANA.}

Late summer or autumn flowering erect herbs, usually I-2 ft. high. Leaves simple, alternate, usually stalkless, or with a very short stalk, always without teeth or lobes. Flowers solitary or in few flowered, rather close, clusters, bright or dark blue. Corolla funnelform, or tubular, sometimes closed at the summit, or open and spreading, beautifully fringed in some species. Fruit a dry pod. (Gentianaceae.) The five species here included are separated thus:

Flowers conspicuously fringed ......... Fringed Gentian no. $6 \gamma_{2}$ Flowers not fringed

Flowers nearly or quite closed ........ Closed Gentian no. 673 Flowers open, but the summit sometimes incurved.

Leaves linear or lance-linear

Flower solitary, stalked .... One-flowered Gentian no. 674

Flowers in clusters ................... Gentian no. 675

Leaves oval .................. Stiff Gentian no. 676 See also nos. 4I5 and 805 .

672. Fringed Gentian. Gentiana crinita. A showy autumn flowering, mostly biennial herb, $\mathrm{I}-2 \mathrm{~T} / 2 \mathrm{ft}$. high. Leaves opposite, broad and slightly heart shaped at the base, narrowed towards the tip, $\mathrm{I}-2$ in. long. Flowers deep blue, tubular, the four spreading lobes beautifully fringed. In wet meadows or thickets. Quebec and Ontario to Georgia, and westward. October. Fig. 672. A related species, G. procera, with narrower leaves and shorter-fringed flowers, is found from Ontario to New York, and westward.

673. Closed Gentinn. Dasystephana Andrewsii. (Gentiana Andrewsii.) A stout perennial I-2 ft. high, the lower leaves opposite, the upper clustered. Leaves stalkless, lance-oval, 

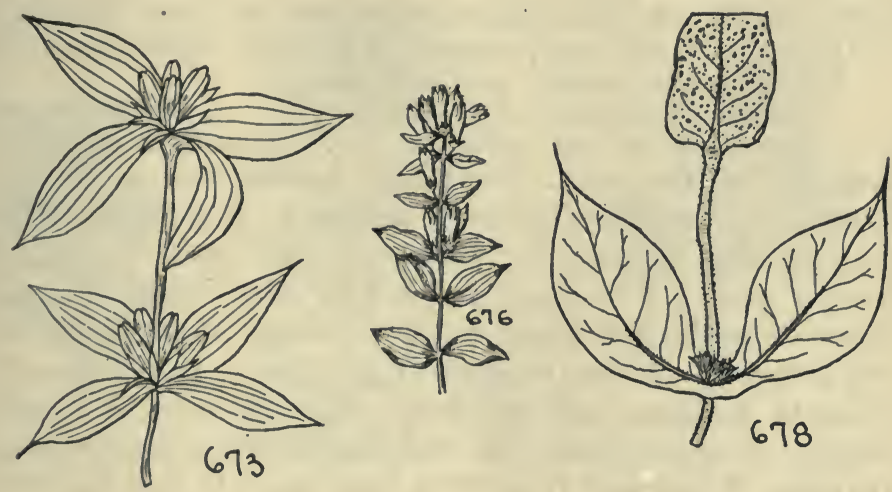

minutely hairy or roughened on the margin, 2-4 in. long. Flowers in bunched clusters, permanently closed, blue, about I in. high. In wet places. Quebec to Georgia, and westward. September. Fig. 673. A related species, the Soapwort Gentian, $D$. Saponaria, has the summit of the club-shaped flowers incurved but not closed. It grows from Ontario to Florida, and westward.

674. One-Flowered Gentian. Dasystephana Porphyrio. (Gentiana Porphyrio.) A smooth perennial about I ft. high with opposite, linear leaves, I-2 in. long. Flower solitary, terminal, stalked, blue, nearly 2 in. high. Corolla funnel shaped, its lobes spreading, not fringed. In pine barrens, New Jersey to Florida. September.

675. Gentian. Dasystcphana lincaris. (Gentiana linearis.) An unbranched, erect smooth herb I-2 ft. high with opposite, lance-linear, pointed leaves $1 / 2-3$ in. long. Flowers in close clusters, blue. Corolla $\mathrm{I}-\mathrm{I} 3 / 4$ in. high, its small lobes neither incurved nor spreading. In mountain bogs, New Brunswick and Ontario to Maryland, and westward. September.

676. Stiff Gentian. Gentiana quinquefolia. With flowers much resembling No. 675, but sometimes slightly yellowish. Leaves oval, stalkless, about $1 \frac{1}{2}$ in. long. In dry or moist places. Maine and Ontario to Florida, and westward to Michigan. (Not 5-leaved as its Latin name suggests.) September. Fig. 676 . 
677. Flowers not blue (pale lavender blue in Phlox No. 682). Leaves narrowly linear, scarcely $1 / 4$ in. wide...Gerardia no. 683

Leaves broader, usually over $I$ in. wide

Flowers in terminal, close clusters ........ Phlox no. 679

Flowers in the leaf joints .......... Horse Gentian no. 678 678. Horse Gentian. Triosteum perfoliatum. (Caprifoliaceae.) A coarse finely-haired perennial, $2-4 \mathrm{ft}$. high, the stem passing through the large opposite leaves which are broadly oval, 4-8 in. long, and 2-4 in. wide. Flowers small, clustered in the leaf bases, purplish brown. Fruit orange or red, crowned with the remains of the flower. In rich woods. Mass. to Alabama, and westward. June. Fig. 678. A related species, $A$. aurantiacum, has the leaf-bases not surrounding the stem. It is found from New Brunswick to No. Carolina and westward.

\section{PHLOX. PHLOX.}

Erect herbs, some sorts prostrate, with opposite toothless leaves and showy flowers in terminal or lateral, more or less close, clusters. Corolla rather long tubular, the tube thin, expanding at the summit into five broad, spreading, usually blunt lobes. Fruit a dry pod. (Polemoniaccae.) For the Ground Pink, P. subulata, see No. 727. See also No. 666.

Plants erect, I-3 ft. high

Flowers and foliage smooth or nearly so $\ldots \ldots \ldots \ldots \ldots \ldots$.

Flowers and foliage hairy, often sticky...Prairie Phlox no. 68I

Plants more or less procumbent ........ Wild Blue Phlox no. 682 680. Garden Phlox. Phlox paniculata. An erect, usually smooth, perennial, 2-3 ft. high. Leaves oblong or lanceoblong, pointed at the tip, and narrowed, or very slightly heart-shaped at the base, $2-5$ in. long, about one quarter as wide. Flowers numerous, showy, pink, purple or white, in more or less close clusters at the summit. Corolla tubes very slender. Wild in woods. Penn. to Florida, and westward, frequently cultivated north of this, and sometimes escaping. August. Fig. 680. A related species, P. maculata, is lower, has leaves broadest towards the base, and a purple flecked stem. Connecticut to Florida, and westward. 

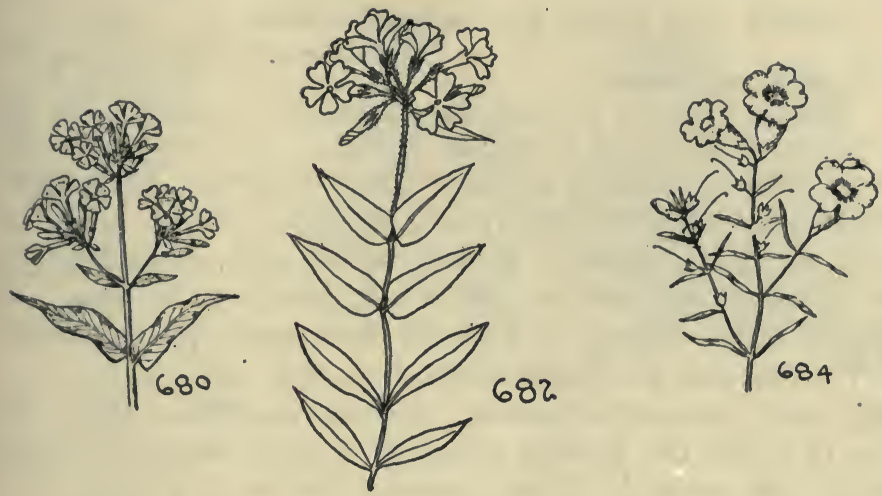

68i. Pratrie Phlox. Phlox pilosa. Not unlike No. 68o, but lower, and with foliage and flowers covered with, usually sticky, hairs. Leaves more slender than in No. 680. In dry places, Ontario, Conn., New Jersey and Florida, not known from New York, but reported westward. May.

682. Wild Blue Phlox. Phlox divaricata. A very showy, woodland semi-prostrate, herb, with finely hairy, somewhat sticky stems and foliage. Leaves broadest towards the base, I-2 in. long. Flowers pale lavender-blue. Corolla with a long narrow tube, the five spreading lobes usually notched. Quebec and Ontario to Penn., Florida and westward. May. Fig. 682.

\section{GERARDIA. AGALINIS. (GERARDIA.)}

Slender, erect, mostly branched herbs with opposite, stalkless, toothless leaves that are narrowly linear, and of ten not $1 / 8$ in. wide, and never more than $1 / 4$ in., in those below. Flowers in rather sparse clusters, or solitary, pinkish-purple in all those below. Corolla funnel-shaped, very slightly unsymmetrical. Fruit a many seeded dry pod. (Scrophulariaceae.) See No. 78I. There are nearly a dozen species, mostly separated on technical characters, the four below thus:

Flowers very short stalked.

Flowers an inch long or longer ....... Purple Gerardia no. 684 


\section{A GUIDE TO THE WILD FLOWERS}

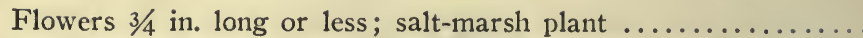

\section{Flowers long stalked}

Salt-marsh Gerardia no. 685

Flowers about $3 / 4$ in. long, usually spotted.... Gerardia no. 686

Flowers $1 / 2$ in. long or less, not spotted ....... Gerardia no. 687 684. Purple Gerardia. Agalinis purpurea. A slender, branched, spreading herb, $I-2 I / 2 \mathrm{ft}$. high. Leaves $I-I / 2 \mathrm{in}$. long, about $1 / 10$ in. wide. Flowers in an open, sparse cluster, or solitary, rose-purple, almost stalkless, I in. long, or slightly more, nearly as wide. In open moist places. Maine to Florida, and westward. September. Fig. 684.

685. Salt-marsh Gerardia. Agalinis maritima. Very like No. 684, but the flowers generally smaller and the foliage often dark purplish. In salt marshes. Maine to Florida. August. A related species, $A$, paupercula, has the inside of the flower throat hairy. It grows in bogs and meadows from Nova Scotia to Tenn., and westward.

686. Gerardia. Agalinis tenuifolia. This resembles No. 684, but its flowers are distinctly long-stalked. Cornlla rose purple, usually spotted, very rarely white, about $3 / 4$ in. long. In dry places. Quebec to Georgia, and westward. September. Very common. Fig. 686.

687. Gernada. Agalinis parvifolia. A delicate slender plant, 8-I6 in. high, its leaves almost thread like. Flowers long stalked, very like those in No. 686, but smaller and unspotted. In dry places. Often very common along the coast. Mass. to Florida and Louisiana. September.

688. Prostrate or low plants, not usually over 8-io in. high, mostly much less.

Leaves stalkless, or merely narrowed towards the base.

Flowers terminal ..................... Bluets no. 692 Flowers not terminal, I or 2 from the leaf joints ............

Leaves with an obvious stalk, and an abruptly broadened blade; flowers in clusters of 2 .

Stalk of the flower cluster as long as, or shorter than the flowers .................... Partridge-berry no. 689 Stalk of the flower cluster 5 times as long as the flower ...... Twin-flower no. 690 

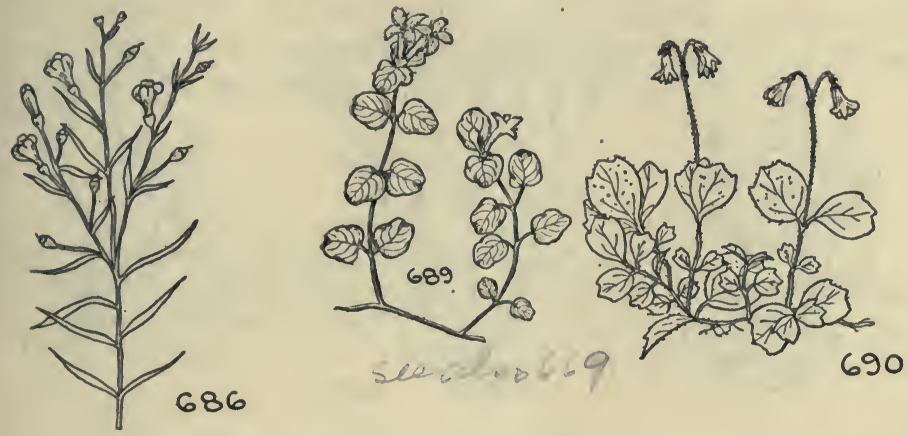

689. Partridge-ierry. Mitchella repens. (Rubiaccac.) Prostrate, partly woody, with opposite, stalked evergreen leaves, that are roundish and $1 / 4-3 / 4$ in. long. Flowers in pairs, the pair relatively short stalked, erect. Corolla, white or pinkish, tubular, its summit split into 4 rather pointed lobes. Fruit red, winter persisting, edible, about $1 / 8$ in. in diameter. In woods. Nova Scotia to Florida, and westward. May. Fig. 689 . For plants of the same family see Nos. 693, 694, 733737.

69o. TWIN-FLower. Linnaea americana. (Linnaea borcalis.) (Caprifoliaceae.) A somewhat woody, slightly hairy, prostrate plant, with roundish, evergreen stalked leaves, $1 / 4-3 / 4$ in. long. Flowers in pairs, nodding, at the summit of a stalk five times the length of the flower. Corolla pink or purplish, tubular, its summit split into 5 rounded lobes. In woods, especially in the uplands. Newfoundland to New Jersey and Maryland, and westward. July. Fig. 690.

69i. Scarlet Pimpernel. Anagallis arvensis. (Primulaceac.) A prostrate European weed of waste places, but often appearing native on moist banks. Leaves opposite, stalkless, almost stem-clasping, oval, $1 / 3-3 / 4$ in. long. Flowers usually 2 from each leaf pair, scarlet or blue. Corolla united, but without a tube, its lobes broad and spreading. Fruit a round, manyseeded capsule. Almost throughout North America. MayAugust. Fig. 691. See also No. 466. 

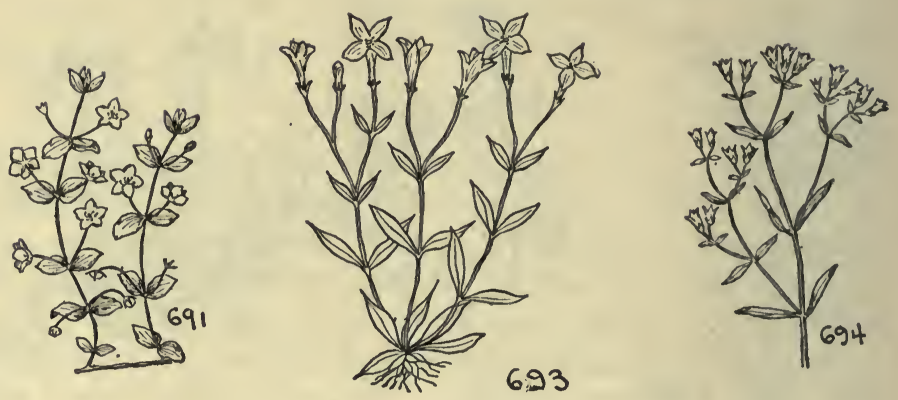

692. BLUETS. QUAKER-LADIES, HOUSTONIA.

Low herbs with basal and opposite, toothless leaves that, in our species, are without a stalk, as the leaf is narrowed toward the stalk-like base. Flowers solitary, or a few, in open, not very floriferous clusters. Corolla tubular, its summit splitting into 4 rather sharp pointed segments. Fruit a dry lobed capsule. (Rubiaceae.) See also Nos. 689, 733 and 737. The two below are:

Corolla lobes spreading; flowers blue with a yellow center ...... Quaker-ladies no. 693

Corolla lobes erect; flowers pale lavender ......... Bluets no. 694 693. Quaker-ladies. Houstonia coerulea. Growing in dense sod-like mats, not over 6 in. high. Leaves lance-oval, narrowed towards the base, about $1 / 2$ in. long. Flowers $I$ or 2 to a stalk, mostly blue, sometimes violet or even white, with a yellow eye, the four spreading lobes cross-like. In wet meadows, or in moist rocky banks. Nova Scotia and Quebec to Georgia, and westward, mostly in the uplands. May-July. Fig. 693 .

694. Bluets. Houstonia longifolia. Growing in isolated clumps, and usually about 8 in. high, the plant stiff. Leaves resembling those in No. 693. Flowers several in loose, terminal clusters. Corolla tubular, its small lobes erect, not cross-like, scarcely $1 / 4$ in. long, pale lavender. In dry open places, especially along the coast. Maine and Ontario to Georgia, and westward. May-September. Fig. 694. A re- 
lated species, $H$. ciliolata, has the margins of the basal leaves finely hairy. It grows on moist rocks from Ontario to West Virginia, and westward.

695. Plants with conspicuously milky juice.

Flowers tubular, without an obvious crown...Dogbanes no. 705 Flowers with an obvious crown (see Fig. 697-704) .......... .............................. Milkweeds no. 696

696. MILKWEEDS. ASCLEPIAS.

Tall rather coarse wholly American herbs with a milky juice and opposite clustered or alternate leaves (in our species) that are toothless, but sometimes wavy-margined. Flowers in dense close terminal or lateral clusters that are umbel-like (see No. 703). Corolla deeply 5-parted, the segments pointing downward at flowering time, and above these a crown of 5 hooded structures. Fruit a long, somewhat swollen pod, packed with silky tailed seeds. (Asclepiadaceac.) See Nos. 200 and 201 for two trailing plants of this family.

Flowers orange; leaves nearly all alternate

Flowers not orange

Flowers red or purple; leaves opposite

Flowers about $1 / 2$ in. wide, the crown about $1 / 4$ in. high ...... Purple Milkweed no. 698

Flowers about $1 / 4$ in. wide, the crown about $1 / 8$ in. high ...... Swamp Milkweed no. 699 Flowers greenish, purplish, yellowish, or white

Leaves of an oblong or oval type

Plants smooth

Leaves wavy-margined, almost stalkless

Milkweed no. 700

Leaves.not wavy-margined, obviously stalked

Leaves opposite ............. Poke Milkweed no. 7or

Leaves 4 at a joint ............... Milkweed no. 702

Plants with leaves white woolly on the under side ........

...................... Common Milkweed no. 703

Leaves narrowly linear in clusters of $3-7 \ldots \ldots . . . . .$.

Whorled Milkweed no. 704 

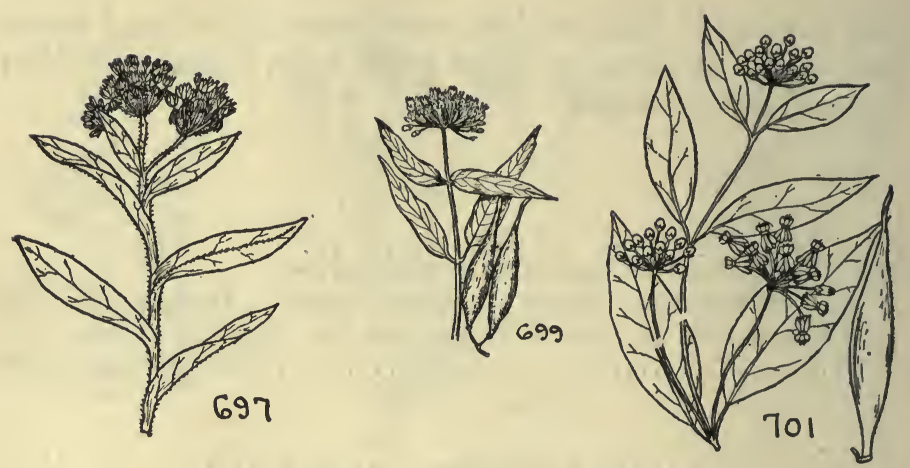

697. Butterfly-weed. Asclepias tuberosa. A stout, stiffhairy plant, usually branched near the top, I-2 ft. high. Leaves numerous, mostly alternate, of an oblong type, stalkless, 2-5 in. long, more or less wavy-margined. Flowers brilliant orange, in a dense showy cluster that is often 3 in. wide. Pod erect, $4-5$ in. long. In dry places, Maine and Ontario to Florida, and westward. Summer. Fig. 697.

698. Purple Milkweed. Asclepias purpurascens. Usually unbranched, and 2-4 ft. high. Leaves opposite, 3-8 in. long, clearly but shortly stalked, oblong and tapering to a point. Flowers in dense showy clusters, deep purple. Pod erect, 4-5 in. long, downy. In dry places. Ontario and New Hampshire to No. Carolina, and westward. July. A related species, $A$. rubra, has red flowers, and is found in moist places only from New Jersey to Florida, and westward to Missouri and Texas; not in the northeast.

699. Swamp Milkweed. Asclepias incarnata. Smooth, or nearly so, and not unlike No. 698, but the leaves narrower, and the flowers reddish-purple and smaller. Pods erect, almost smooth, 2-3 in. high. In wet places, usually very common. New Brunswick and Ontario to Tenn., and westward. August. Fig. 699. A closely related plant, $A$. pulchra, also of moist places, is densely hairy throughout. It grows from Nova Scotia to Minnesota and southward along the coast to Georgia. 700. Milkweed. Asclepias amplexicaulis. A smooth milkweed of dry sandy places, 2-3 ft. high. Leaves of an oval- 

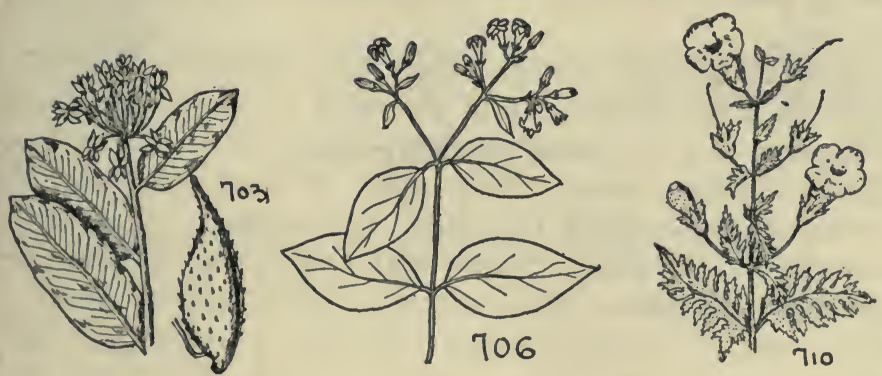

oblong type, distinctly wavy-margined, almost stalkless, opposite, $3-5$ in. long. Flowers greenish-purple, the crown pinkish. Pods erect, downy, 4-6 in. long. New Hampshire to Florida, common along the coast, more rare inland, to Minnesota and Nebraska. June-August.

70r. Poke Milkweed. Asclepias exaltata. (Asclepias phytolaccoides.) A nearly smooth erect perennial 3-6 ft. high. Leaves opposite, stalked, lance-oblong, narrowed both ends, $4 \rightarrow$ in. long, rather thin. Flowers in a comparatively loose cluster, greenish purple, the crown pink or white. In woods and thickets, Maine to Georgia, and westward. July. Fig. 701. A related plant, $A$. variegata, has some of the leaves occasionally in fours, and a whitish-purple flower. It is found in dry woods from Long Island, N. Y. to Florida, and westward.

702. Milkweed. Asclepias quadrifolia. Stem slender, usually unbranched, I-2 ft. high. Leaves very like those of No. 70I, but mostly in fours. Flowers in a rather open cluster, pinkish-white. Pod very slender, erect, $3-5$ in. long and smooth. In woods and thickets, nowhere very common. Maine and Ontario to Alabama, and westward. June.

703. Сommon Milkweed. Asclepias syriaca. The commonest of all our Milkweeds, a stiff, stout perennial, 3-5 ft. high. Leaves oblong or oval-oblong, opposite, $4-9$ in. long, stout stalked. Flowers in large globe-like clusters, greenish-purple or greenish white. Pods erect, 3-5 in. long, swollen toward the base, warty, and covered with soft prickles. Nearly every- 
where. New Brunswick to No. Carolina, and westward. July. Fig. 703 .

704. Whorled Milkweed. Asclepias verticillata. Differing from all other Milkweeds in our area in having the leaves in clusters of $3-7$. Leaves narrowly-linear, about $2 \mathrm{I} / 2$ in. long. Flower clusters many, rather open, its stalklets hairy, the corolla greenish-white or white. Pod erect, 2-3 in. long, smooth. In dry places. Maine and Ontario to Florida, and westward. August.

\section{DOGBANES. APOCYNUM.}

Perennial, nearly always branched, milky-juiced, herbs with opposite toothless leaves. Flowers in lax, more or less open clusters that are terminal or from among the upper leaves. Corolla small, pink or white, bell-shaped or tubular, but not crowned, as in the Milkweeds. Fruit a long slender, scarcely swollen pod, its seeds silky-tipped. (Apocynaceae.) There are several species, but most of them rather difficult to identify. The two best known in our area are:

Flowers greenish-white; leaves rounded at the base ..........

Flowers pink; leaves pointed at base ..... Indian Hemp no. 707 706. Dogbane. A pocymum androsaemifolium. Widely branching, erect herb, I-4 ft. high. Leaves oval, stalked, smooth above, a little hairy and paler beneath, 2-4 in. long. Flowers about $1 / 4$ in. wide, white or greenish-white, the corolla funnel shaped, its lobes slightly recurved. Pods often in pairs, pencil-thick, about 4 in. long. In dry places. Nova Scotia to Georgia and westward. June. Fig. 706.

707. Indian Hemp. Apocynum cannabinum. Resembling No. 706 , but the leaves narrowed at the base, the flowers pink, and the foliage slightly bluish-green. Pods as in No. 706. In fields and thickets. New England to Alabama and westward. June. 
708. Leaves lobed or divided, or with obvious marginal teeth. (Nos. 709-724.)

Flowers not yellow, the individual ones $1 / 2$ in. long or less no. 712 Flowers yellow, $\mathrm{I}-2$ in. long ............ False Foxglove no. 709

\section{FALSE FOXGLOVE. DASYSTOMA.}

Tall, usually branching herbs, with mostly opposite leaves, but sometimes a few in clusters. Leaves, in our species, toothed, or divided, or lobed, or more or less cut. Flowers large and showy, yellow. Corolla broad funnel-shaped, very slightly unsymmetrical, always hairy on the inside of the tube, I-2 in. long. Fruit an oblong, pointed, pod. (Scrophulariaceae.) See No. 78r.

Leaves with many sharp teeth, or lobes; sticky-hairy .......... ........................ False Foxglove no. 7ro

Leaves with a few blunt teeth or lobes; slightly hairy but not sticky ..................... False Foxglove no. 7II 7 10. False Foxglove. Dasystoma pedicularia. (Gerardia pedicularia.) Stems leafy, branched, I-4 ft. high, stickyhairy. Leaves almost stalkless, or the lower ones shortstalked, oval in general outline, but much cut or toothed into sharp pointed segments or teeth, I- 3 in. long. Flowers in a loose open cluster, or nearly solitary. Corolla yellow, I-I I 12 in. long, hairy also on the outside. In dry places, mostly in woods. Maine and Ontario to Florida, and westward. August. Fig. 7 IO.

7ri. False Foxglove. Dasystoma flava. (Gerardia flava.) Similar to No. 710, but the leaves with only a few blunt lobes or teeth and slightly downy, not sticky. The flower also similar, but not hairy on the outside. In similar situations, and with nearly the same range. August. Fig. 7II. There is still a third species, $D$. virginica, which is perfectly smooth, bluish-green, and has sharp teeth or lobes to the leaf, but fewer than No. 710, and more than No. 7II. In dry woods. Maine to Florida and westward to Illinois and Minnesota. 

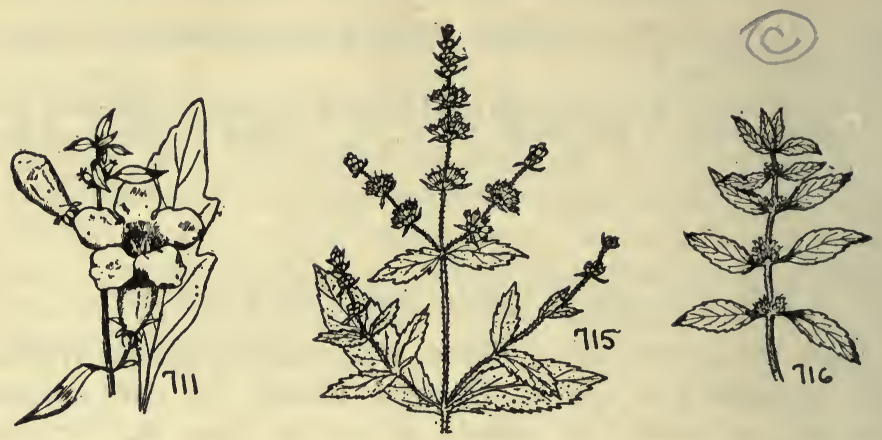

712. Flowers not yellow, the individual ones $1 / 2$ in. long or less.

Plants 2-5 ft. high

Leaves simple .................... Vervain no. 722

Leaves apparently compound ...... Garden Valerian no. 72I

Plants 6-18 in. high

Plants not aromatic

............... Bugle-weed and Water Hoarhound no. 717

Plants aromatic, with strong mint odor ...... Mint no. 713

\section{MINT. MENTHA.}

Erect, strongly aromatic herbs with the familiar peppermint odor, with opposite, toothed, usually dotted leaves, and an angled or square stem. Flowers small, usually $1 / 4$ in. long in close tight head-like clusters among the leaves, or in terminal spikes, or both. Corolla tubular, almost symmetrical, or very slightly I-sided, pale purplish-white. (Lamiaceac.) See No. 740. There are several species, all native of Europe, except the American Wild Mint. The most common are:

Flowers in terminal spikes, or a few also among the upper leaves Plants smooth .................. Common Mint no. 714 Plants hairy ................... Horse Mint no. 715 Flowers in tight close clusters, wholly among the leaves ........ ......................... American Wild Mint no. 716 7i4. Common Mint. Mentha spicata. A smooth perennial 8-18 in. high. Leaves opposite, sharply toothed, almost stalk- 
less, lance-shaped, $I \frac{1}{2}-2^{1} / 2$ in. long. Flowers in usually branched, somewhat loose and interrupted spikes, the central one longer than the side ones. In moist fields and waste places, almost throughout North America. August. A closely related species, $M$. piperita, the Peppermint, is also smooth, but has denser, not interrupted spikes, and has a similar range.

7I5. Horse Mint. Mentha longifolia. Suggesting No. 7I4, but the flower spikes longer and more pointed, and the whole plant hairy. In waste places. Conn. to Delaware, and west to Ohio. July-October. Fig. 7I5. A related species, $M$. aquatica, the Water Mint, is also hairy, but has broad, oval leaves, and shorter, denser spikes of flowers. It is found from Nova Scotia to Penn. and Georgia. Both are natives of Europe.

7i6. American Wild Mint. Mentha canadensis. A hairy, somewhat weak perennial, 8-18 in. high. Leaves lance-shaped, narrowed to a stalk-like base, 2-3 in. long, and sharply toothed. Flowers in dense tight, round, clusters, among the upper leaf joints. In moist places. New Brunswick to Virginia, and westward. July-October. Fig. 716. A related European species, $M$. arvensis, the Corn Mint, differs in having leaves rounded at the base, and with more rounded leaf-teeth. It is widely distributed, but locally rare.

\section{BUGLE-WEED AND WATER HOARHOUND. LYCOPUS.}

Suggesting the Mints in habit and foliage, but not aromatic. Flowers in dense tight clusters, wholly from among the leaves, never in terminal clusters. Corolla very small, usually under $1 / 8$ in. high, often partly or wholly hidden by the surrounding united sepals which have long points in some species. (Lamiaceae.) See No. 740. The plants are difficult to identfy, and only three are included here:

Tips of united sepals blunt, not half hiding the tiny flower .....

Bugle-weed no. 718

Tips of united sepals long-pointed, half hiding the tiny flower 

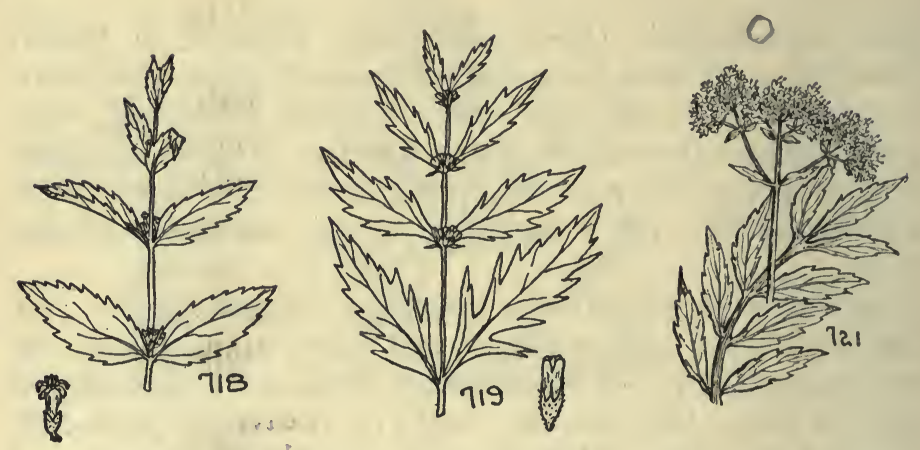

Leaves deeply cut ............. Water Hoarhound no. 719

Leaves merely sharply toothed ...... Water Hoarhound no. 720 7 18. Bugle-WEed. Ly'copus virginicus. A perennial, 6-18 in. high often with long thread like runners. Leaves opposite, often greenish-purple, lance shaped, or lance-oval, narrowed into a stalk-like base. Flowers in dense clusters at the leafjoints. Corolla scarcely hidden by the blunt tips of the united sepals. In wet places. New Hampshire to Florida, and westward. August. Fig. 7 I8.

7I9. WATER HoArhound. Lycopus americanus. A stiff perennial I2-20 in. high, usually smooth. Leaves, especia!ly towards the base, with deep incisions, above this, merely deeply toothed. Flowers as in No. 7I8, but the long points of the united sepals partly hiding the tiny corolla. In wet places. Newfoundland to Florida, and westward. June-October. Fig. 7 I9.

720. Water Hoarhound. Lycopus europaeus. Resembling No. 719, but the leaves merely deeply toothed, and without the deep incisions near the base. It grows in waste places, Mass. to Virginia, not common. Native of Europe. August.

721. Garden Valerian. Valcriana officinalis. (Valcrianaceae.) An erect, mostly hairy, rather strong smelling perennial, 2-5 ft. high. Leaves opposite, apparently compound, the 9-I2 thin, remotely toothed segments appearing like leaflets. Flowers small, pinkish-white, in a large, branched, manyflowered, terminal cluster. Corolla tubular, very slightly ir- 
regular, not 2-lipped. As an escape from gardens, New York, New Jersey and Ohio. Native of Eurasia. July. Fig. 721.

\section{VERVAIN. VERBENA.}

Tall rather coarse herbs with 4 -sided stems, and opposite toothed leaves. Flowers in long, very slender, usually branched, interrupted, terminal spikes. Corolla funnel-shaped, not over $1 / 4$ in. long, very slightly unsymmetrical, but scarcely 2-lipped. (Verbenaceae.)

Flowers blue ....................... Blue Vervain no. 723

Flowers white .................. White Vervain no. 724 723. Blue Vervain. Verbena hastata. An erect, stiff or wiry perennial, 3-6 ft. high. Leaves lance-oblong, coarsely toothed, stalked, 3-6 in. long, branched. Flowers minute, blue, very rarely white. In moist places, or in fields. Nova Scotia to Florida, and westward. June-September. Fig. 723. A related species, $V$. angustifolia, has the leaves narrowed to a stalk-like base. It grows in dry places from Mass. to Florida, and westward, but not commonly.

724. White Vervain. Verbena urticifolia. Much resembling No. 723 , but with white flowers that are in somewhat more interrupted spikes. In fields and waste places. New Brunswick to Florida, and westward. June-September.

725. Leaves more than 2 at a joint, often several, sometimes crowded.

Divisions or lobes of the corolla $4 \ldots \ldots \ldots \ldots \ldots \ldots$ no. 730

Divisions or lobes of the corolla 5

Leaves few, broad, clustered at ends of the slightly woody stem; plant aromatic ............. Wintergreen no. 726 Leaves numerous, less than $1 / 8$ in. wide, crowded

Stems herbaceous; leaves bunched at the joints ........ Ground Pink no. 727

Stems woody; leaves crowded all along the stem

Flower stalked; on alpine summits .. Diapensia no. 728 Flower stalkless; in sandy pine barrens .. Pyxie no. 729 

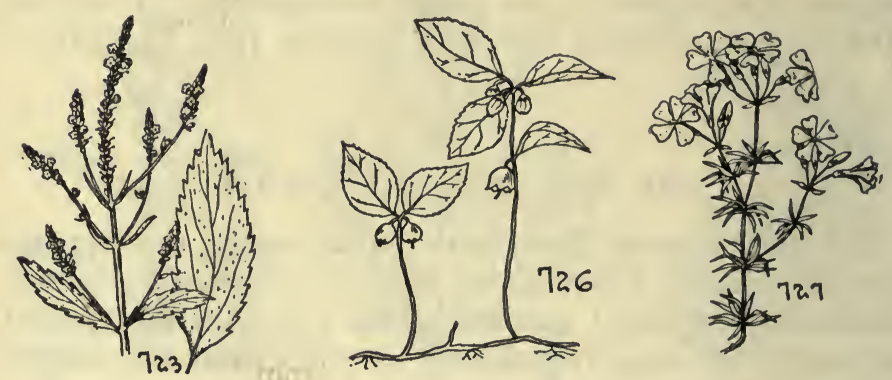

726. Wintergreen. Gaultheria procumbens. (Ericaceae.) An aromatic smooth, prostrate plant with a few evergreen leaves clustered near the ends of the slightly woody stems. Leaves oval, or oval-oblong, I-2 in. long, short stalked, shining above, and with short, bristle-tipped teeth. Flower solitary, or a few, the corolla bell shaped, and with 5 short blunt lobes. Fruit red, roundish, about $3 / 8$ in. in diameter. In woods. Newfoundland to Georgia, and westward. June-September. Fig. 726. See No. 668.

727. Ground Pink. Phlox subulata. (Polemoniaceae.) A low herb, forming dense mats in rocky or sandy places. Leaves almost thread-like, 7-18 at each cluster, the stem leafless between the clusters. Flowers in terminal, not dense clusters, pink, magenta, or white. Corolla with a long narrow tube, the 5, notched lobes spreading. New York to Florida, west to Michigan and Kentucky. Commonly cultivated, and sometimes escaping. May. Fig. 727. See also Nos. 666 and 679. 728. Diapensia. Diapensia lapponica. (Diapensiaceae.) A low dense cushion-like plant, with short woody stems. Leaves crowded all along the stems, stalkless, evergreen, less than $1 / 4$ in. long. Flower solitary, on a stalk overtopping the cushion about 3 in. Corolla broadly bell shaped, white, waxy, about $1 / 3$ in. long, its 5 blunt lobes short. On alpine summits, mostly above timber line, Adirondacks and Mountains of New England, northward to the Arctic. June. Fig. 728. 729. Pyxie. Pyridanthera barbulata. (Diapensiaceae.) Prostrate, very leafy plant growing in flat mats or patches. Leaves 

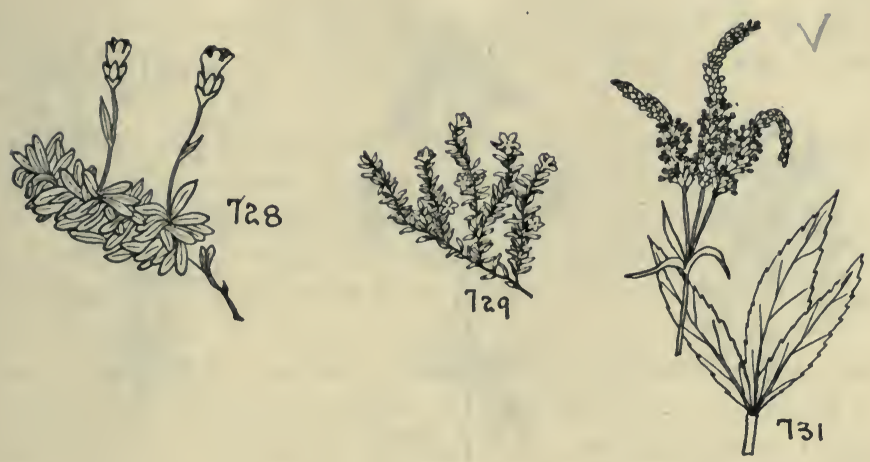

evergreen, crowded all along the short woody stems, about $1 / 4$ in. long. Flowers solitary at the ends of the branches, stalkless. Corolla bell-shaped, white or rarely pink, the 5 blunt lobes somewhat spreading, about $1 / 4$ in. wide. In dry sand of the pine barrens. Southern New Jersey to No. Carolina. April. Fig. 729.

730. Divisions or lobes of the corolla 4.

Plants low, weak, more or less sprawling ..... Bedstraw no. 732 Plant erect, $2-7 \mathrm{ft}$. high ............. Culver's-root no. $73 \mathrm{I}$ 73I. Culver's-Root. Leptandra virginica. (Veronica virginica.) (Scrophulariaceae.) An erect, stiff, perennial, 2-7 ft. high. Leaves in clusters of 3-9, stalked, lance-oblong, 3-6 in. long, sharply toothed. Flowers in long showy branched terminal spike-like clusters. Corolla tubular, essentially symmetrical, about $1 / 8$ in. long, its 4 lobes very short. In moist woods or meadows. Ontario to Alabama, and westward. July. Fig. 73r. See No. 78r.

\section{BEDSTRAW. GALIUM.}

Weak sprawling herbs with leaves in clusters, and the 4angled stems leafless between these clusters. Flowers very 

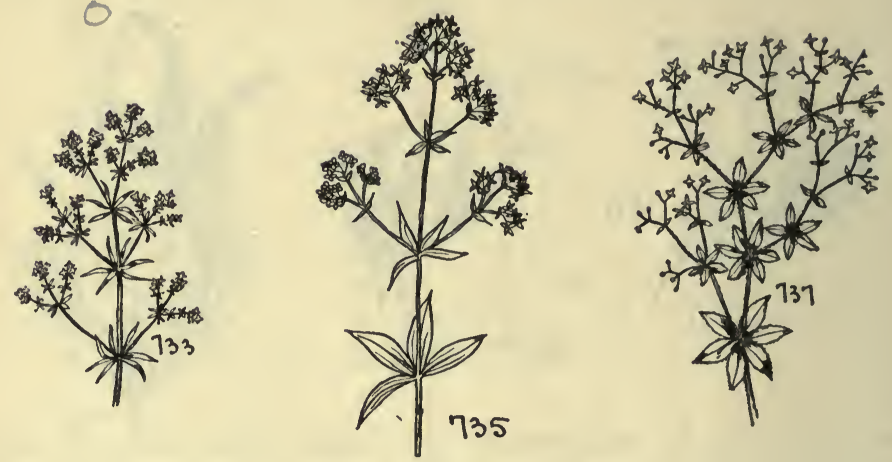

small, yellow, green, or white, mostly in rather open lax clusters. Corolla almost without a tube, its 4 lobes somewhat flattened. Fruit 2-lobed, smooth or hairy or bristly. (Rubiaceae.) See also Nos. 689, 693, and 694. There are several other species.

Flowers yellow ................. Lady's Bedstraw no. 733

Flowers white or green:

Leaves in clusters of 4

Leaves oval ................... Cross Cleavers no. 734

Leaves lance-shaped or lance-linear ....... Bedstraw no. 735

Leaves in clusters of 5 or 6 , or more

Fruit bristly; flower clusters from among the leaves .....

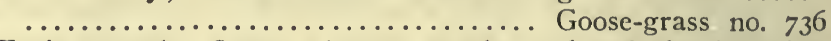

Fruit smooth; flower clusters at the ends of the branches

733. Lady's Bedstraw. Galium verum. Mostly erect, 6-20 in. high, the stem smooth or finely roughened. Leaves in 6's or 8's, linear, almost thread-like. Flowers yellow, in small but profuse terminal clusters. Fruit smooth. In fields and waste places. Maine and Ontario to New York and Penn. Eurasian. May-September. Fig. 733.

734. Cross Cleavers. Galium circaezans. A somewhat hairy, but not rough-stemmed plant with the leaves in 4 's. Leaves stalkless, oval or lance-oval, $1 / 2-\mathrm{I} / 2$ in. long, $1 / 4-3 / 4$ in. wide. Flowers white, in sparse clusters that arise among the leaves, and may also be terminal. Fruit bristly. In dry places. Quebec and Ontario to Florida, and westward. June. A related 
plant, G. lanceolatum, with leaves more lance-oval in shape is found from Quebec and Ontario to No. Carolina, and westward.

735. Bedstraw. Galium boreale. Smooth stemmed and mostly without hairs. Leaves in 4's, lance-shaped, or lance-linear, I$21 / 2$ in. long, the margins somewhat hairy. Flowers all in terminal clusters, white, the clusters branched. Fruit bristly. In moist places. Quebec to New Jersey, Penn., and westward. June. Fig. 735 .

736. Goose-Grass. Galium Aparine. A weak bristly-stemmed annual, sprawling over bushes. Leaves in 6's or 8's, linear or lance-linear, $\mathrm{I}-3$ in. long, narrowed to a stalkless base, rough on the margin and midrib. Flowers white, in sparse clusters, from among the upper leaf-clusters, not at the ends of the branches. Fruit bristly. Common in various places. New Brunswick to Florida, and westward. May-September.

737. Bedstraw. Galium asprellum. Weak, branched, and reclining on bushes, the stems bristly and rough. Leaves in 6 's or 5 's, oval or lance-oval, bristly-margined, $1 / 3-3 / 4$ in. long. Flowers white in terminal, forked clusters. Fruit smooth. In moist places. Newfoundland and Ontario to No. Carolina, and westward. July. Fig. 737. A related species, G. Claytoni, with the leaves narrowed to a stalk-like base is found in swamps. Quebec to No. Carolina, and westward.

738. Corolla decidedly unsymmetrical, or distinctly 2-lipped. Fruits in opposite pairs, pointing downward...Lopseed no. 739 Fruits not so

Foliage aromatic; stems mostly 4-sided...Mint Family no. 740 Foliage not aromatic; stems not 4 -sided................. ........................ Figwort Family no. 781 739. Lorseed. Phryma Leptostachya. (Phrymaceae.) An erect, somewhat hairy perennial, with a 4 -sided stem, $I^{1 / 2-}$ $3 \mathrm{ft}$. high. Leaves opposite, stalked, broadly oval, rounded at the base, pointed at the tip, coarsely but not sharply toothed, 2-6 in. long. Flowers in long slender spikes which are often 

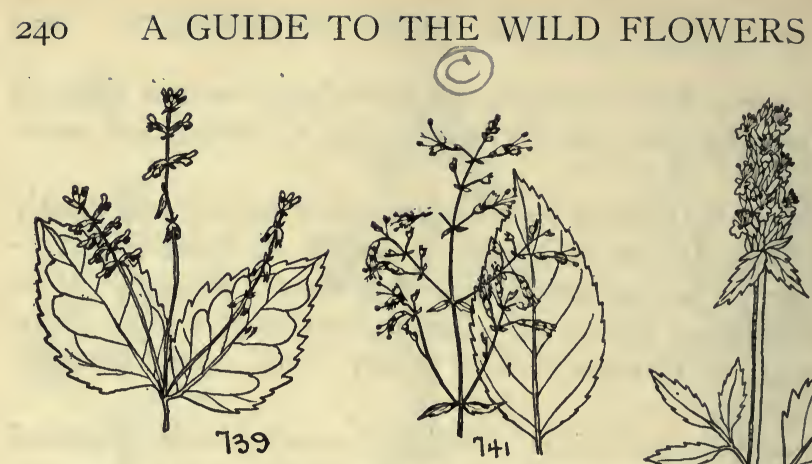

branched, the flowers in opposite pairs. Corolla tubular, 2lipped at the tip. Fruit dry, pointing downward and almost touching the stalk. In woods. New Brunswick to Florida, and westward. July. Fig. 739.

\section{MINT FAMILY. LAMIACEAE.}

An immense family of aromatic herbs (shrubs and trees in the tropics) with simple, opposite leaves, and nearly always a square stem. Flowers irregular and unsymmetrical, in those below, mostly 2-lipped, arranged in various kinds of clusters, most commonly in rather dense ones, often in terminal spikes or racemes. Corolla with a short or long tube, 3 of its lobes larger than the other two. The fruit consists of four I-seeded nutlets, enclosed by the remains of the flower. Common examples are savory, lavender, and many old-fashioned garden herbs. All of them are difficult to identify without the use of technical characters, and for this reason illustrations will be given for all included here. For other plants of the family see Nos. 713-720.

Flowers neither yellow, nor greenish-yellow ......... no. 743

Flowers greenish-yellow, or yellow

Flowers yellow, fringed, in a loose open cluster ......................................... Balm no.

Flowers greenish-yellow, not fringed, in dense terminal spikes Giant Hyssop no. 742 
74I. Horse Balm. Collinsonia canadensis. An erect, branched perennial, $2-5 \mathrm{ft}$. high. Leaves oval, or oblong-oval, shortstalked, sharply toothed, 6-Io in. long. Flowers yellow, in a large loose open few-flowered cluster, that may be I ft. long. Corolla very irregular, one of its lobes larger than the others and fringed. In rich woods. Quebec and Ontario to Florida, and westward. July-September. Fig. 74I.

742. Giant Hyssop. Agastache nepetoides. A smooth stout perennial $2-5 \mathrm{ft}$. high, usually branched towards the top. Leaves oval, wedge-shaped at the base, pointed at the tip, stalked, 2-6 in. long, and toothed with blunt teeth. Flowers in a dense terminal spike which is $4-15$ in. long, greenishyellow. Corolla 2 -lipped, about $1 / 3$ in. long. In woods and thickets. Quebec and Vermont to Georgia, and westward. August. Fig. 742.

743. Flowers neither yellow, nor greenish-yellow. (Mint Family continued.)

Stem leaves with an obvious and distinct stalk, not merely narrowed to a stalk-like base (The two exceptions are Skullcaps, nos. 778 and 779$) \ldots \ldots \ldots \ldots \ldots \ldots \ldots \ldots \ldots \ldots \ldots \ldots \ldots \ldots \ldots$ no. 761

Stem leaves without an obvious and distinct stalk, the leaf stalkless, or merely narrowed to a stalk-like base. (The only exception is the Rough Hedge Nettle, no. 753)

Leaves wholly without marginal teeth (except in the Wild Basil, no. 757) ............................. 755 Leaves distinctly, but sometimes shallowly toothed (except in the Hyssop Hedge Nettle, no. 751)

Flower clusters exclusively, or overwhelmingly terminal, not among the upper leaves $\ldots \ldots \ldots \ldots \ldots \ldots \ldots$ no. 748

Flower clusters mostly among the upper leaves, some occasionally terminal

Leaves narrowed at the base American Pennroyal no. 744 Leaves broad at the base

Flower clusters stalked ......... Stone Mint no. 745 Flower clusters essentially stalkless

Leaf-teeth obvious ............. Field Basil no. 746

Leaf-teeth shallow and irregular .... Bugle no. 747

744. American Pennyroyal. Hedeoma pulegioides. An annual, weedy, hairy, plant with a much branched stem, 6-I 5 

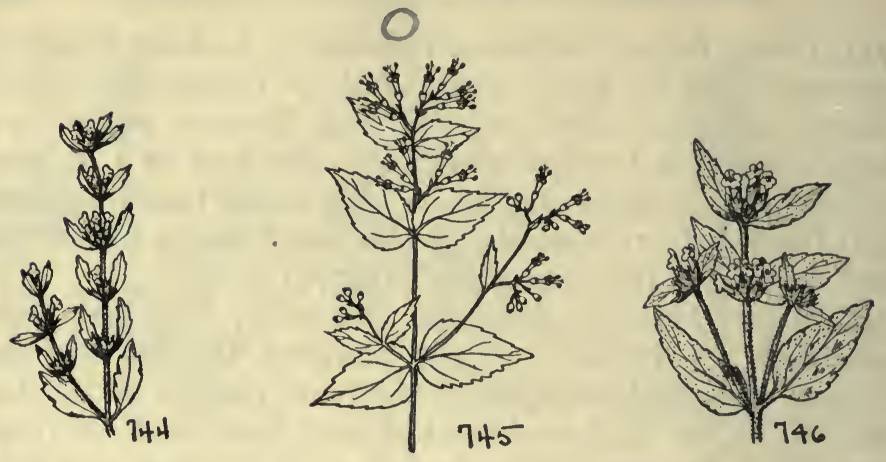

in. high. Leaves $1 / 2-1 / 2$ in. long broadest towards the tip. Flowers in dense, head-like, stalkless clusters, among the leaves. Corolla about $1 / 4$ in. long, bluish-purple. In dry places, Nova Scotia and Ontario to Florida, and westward. August. Fig. 744.

745. Stone Mint. Cunila origanoides. A stiff branching perennial, 8-20 in. high. Leaves broadest towards the practically stalkless base, oval, $1 / 2-11 / 2$ in. long. Flowers in long stalked clusters from the upper leaves, the clusters rather open. Corolla purplish-pink, almost $1 / 2$ in. long. In dry woods. Long Island, N. Y., to Florida, and westward. August. Fig. 745 .

746. Field Basil. Clinopodium vulgare. (Satureia vulgaris.) An erect hairy perennial, I-2 ft. high. Leaves broadest towards the base, those of the stem stalkless, but some of the lowest ones short stalked, $I-I / 2$ in. long, pointed towards the tip, distinctly toothed. Flowers in close stalkless clusters among the upper leaves. Corolla purple, pink or white, about $3 / 8$ in. long. In woods and thickets. Newfoundland to No. Carolina, and westward. June-October. Fig. 746.

747. Bugle. Ajuga reptans. A European weed with creeping or erect stems, 6-I 5 in. high. Leaves oval or roundish, stalkless I-3 in. long, the teeth remote and rounded, and the margins in some leaves merely wavy. Flowers rather few in each stalkless cluster from among the leaves. Corolla about 

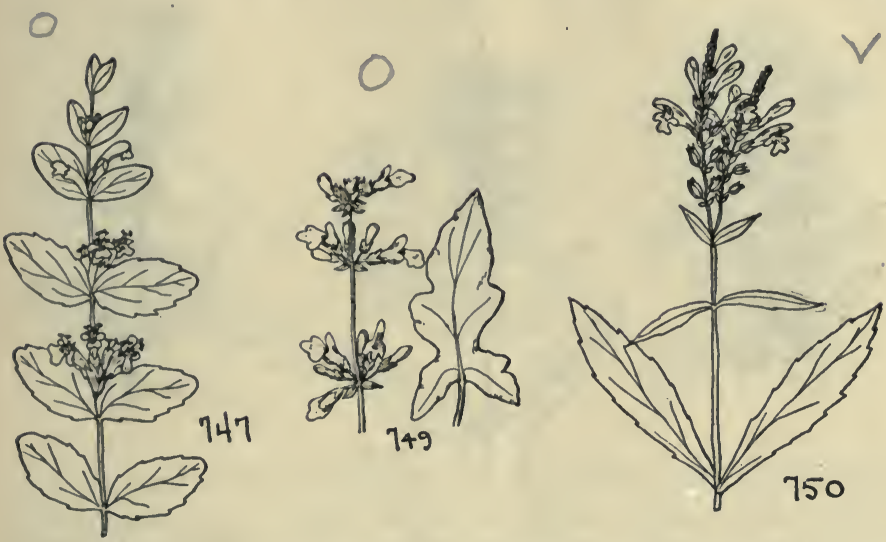

$1 / 2$ in. long, blue or bluish-white. In fields. Quebec and Maine to southern N. Y. May. Fig. 747.

748. Flower clusters exclusively or overwhelmingly terminal, not among the upper leaves. (Mint family continued.)

Basal leaves deeply cut ...............Wild Sage no. 749

Basal leaves, if any, not cut

Corolla at least I in. long, rose-purple .. Dragon-head no. 750 Corolla $\mathrm{r} / 2$ in. long or less

Leaves nearly parallel-margined

Leaves broadest towards the base

Leaf-teeth sharp and regular

Flower spike interrupted ........ Hedge Nettle no. 752

Flower spikes practically continuous ...............

Leaf-teeth shallow and remote .. Ohio Horse Mint no. 754

749. Wild Sage. Salvia lyrata. A usually unbranched perennial I-3 ft. high. Basal leaves somewhat deeply cut or lobed, those of the stem not lobed and irregularly and bluntly toothed. Flowers in a terminal interrupted cluster. Corolla about I in. long, violet, its upper lobe much shorter than the lower. In dry woods. Conn. to Florida, and westward. June. Fig. 749 . 

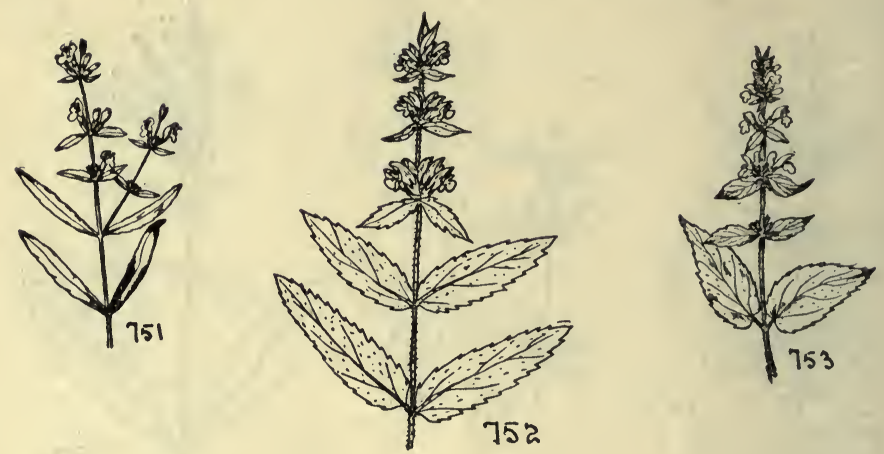

750. Dragon-head. Dracocephalum virginianum. (Physostegia virginiana.) Mostly unbranched, essentially smooth, and I-4 ft. high. Leaves lance-oblong, $2-5$ in. long, narrowed towards the stalkless base, toothed. Flowers in dense terminal spikes, the corolla rose-purple about I in. long. In moist places. Quebec and Ontario to Florida, and westward. Often cultivated and sometimes escaping. August. Fig. 750. 751. Hyssop Hedge Nettle. Stachys hyssopifolia. A practically smooth perennial I-2 ft. high, sometimes a little hairy at the leaf-joints. Leaves parallel margined, I-2 in. long, toothless, or with a few low teeth, stalkless. Flowers in terminal, interrupted, clusters. Corolla light purple, a little more than $1 / 2$ in. long. In open places, Mass. to Florida, and westward. August. Fig. $75 \mathrm{I}$.

752. Hedge Nettle. Stachy's palustris. A stiff-hairy, erect, perennial I-4 ft. high. Leaves broadest towards the base, lance-oblong, stalkless, $2-5$ in. long, coarsely toothed. Flowers in terminal, interrupted clusters. Corolla purplish-red, $1 / 2-3 / 4$ in. long, the upper lip hairy. In moist places, Newfoundland to southern New York, and westward. JuneSeptember. Fig. 752 .

753. Rougin Hedge Netrle. Stachys aspera. (Stachys tenuifolia var. aspera.) A rough-hairy, erect herb 2-4 ft. high. Leaves broadest towards the somewhat heart-shaped base, pointed towards the tip, distinctly stalked, $2-5$ in. long. Flow- 

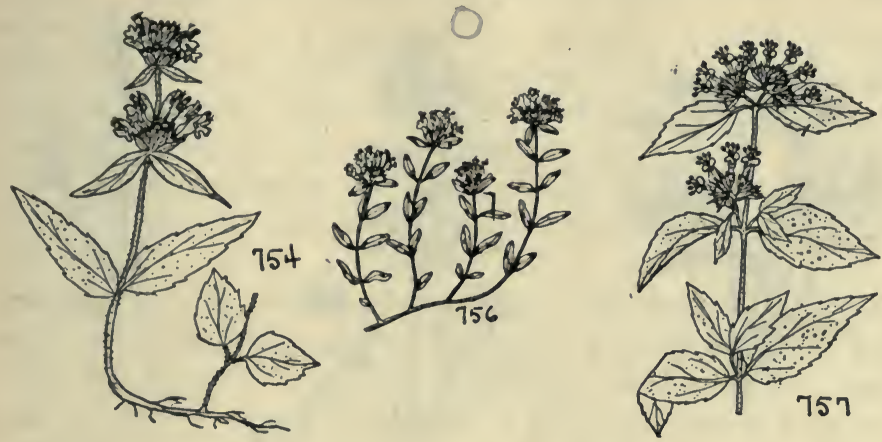

ers in a practically continuous terminal spike, the corolla redpurple, about $1 / 2$ in. long. In moist places, Ontario and Mass. to Florida, and westward. June-September. Fig. 753.

754. Ohio Horse Mint. Blephilia ciliata. A usually unbranched hairy perennial I-2 ft. high. Leaves practically stalkless, broadest towards the wedge-shaped base, pointed at the tip, I-2 in. long, remotely and irregularly blunt toothed. Flowers in a terminal spike, or a few among the uppermost leaves, the corolla hairy, purple, slightly less than $1 / 2$ in. long. In dry places. Vermont to Georgia, and westward. July. Fig. 754 .

755. Leaves wholly without marginal teeth, except in the Wild Basil, No. 757. (Mint Family continued.)

Plants prostrate, forming mats ........ Wild Thyme no. 756

Plants erect, not forming mats

Flowers whitish, or pale lavender

Leaves of an oval type ............ Wild Basil no. 757

Leaves narrow, of a linear type .... Mountain Mint no. $75^{8}$

Flowers purple or bluish-purple

Perennial; base woody; leaves mostly oblong-linear ......

............................ Hyssop no. 759

Annual; base not woody; leaves linear ..... Savory no. 760 756. Wild Thyme. Thymus Serpyllum. A low, tough, but slender Eurasian perennial, forming mats. Leaves stalkless 

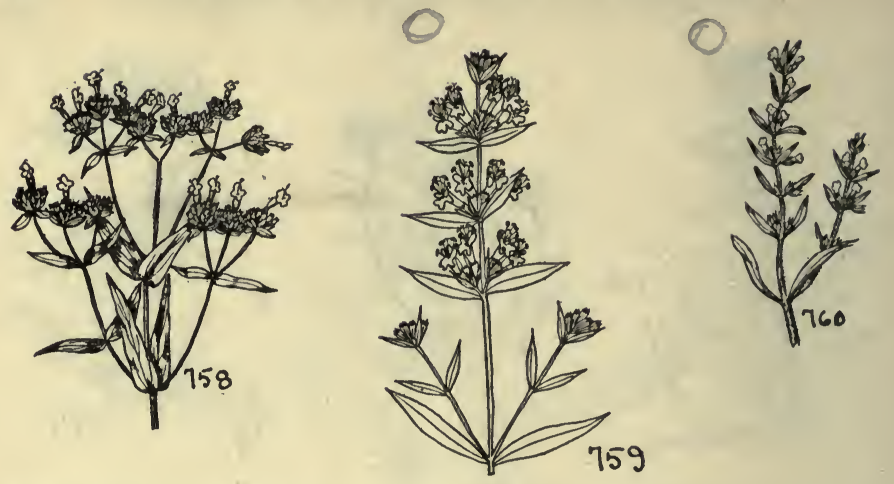

and toothless, $1 / 8-3 / 8$ in. long. Flowers in a dense terminal stalkless globe-like cluster. Corolla very small, purple. In fields and waste places, Nova Scotia to Southern New York and No. Carolina. June-August. Fig. $75^{6}$.

757. Wild Basil. Koellia incana. (Pycnanthemum incanum.) An erect, ashy-grey, hairy perennial, I-3 ft. high. Leaves oval or oval oblong, essentially stalkless, $2-3$ in. long, rather coarsely but remotely toothed. Flowers in loose terminal clusters, or a few among the upper leaves. Corolla pale lavender. The long bristle-like tips of the united sepals are prominent. In dry places. Maine to Florida, and westward. August. Fig. 757. A related species, $K$. mutica, differs in having more crowded flower clusters and in having the tips of the united sepals blunt and triangular. It is found in similar places from Conn. to Penn., and southward to Virginia and Tenn.

758. Mountain Mint. Koellia virginiana. (Pyсnanthemum virginianum.) Suggesting No. 757 , but the leaves long and oblong, or oblong-linear. The flower clusters are more numerous and dense, but the tips of the united sepals are blunt and triangular. In dry places. Quebec and Ontario to Georgia, and westward. August. Fig. 758. A closely related species, $K$. flexuosa, with similar foliage, has bristle tipped extremities to its united sepals. It grows in dry places from Maine to Florida, and westward.

759. Hyssop. Hyssopus officinalis. Erect, many-stemmed, Eu- 
ropean plant, from a perennial woody base. Leaves oblonglinear, or almost oval-linear, tapering both ends, stalkless, toothless, I-2 in. long. Flowers in small, not very dense clusters, scattered among the upper leaves, or terminal. Corolla bluish-purple, not over $1 / 2$ in. long. In fields and along roadsides. Ontario to No. Carolina. August. Fig. 759.

760. Savory. Satureia hortensis. An erect, annual, European weed, 9-18 in. high, and softly hairy. Leaves toothless and stalkless, $\mathrm{I} / 2-\mathrm{I}$ in. long, considerably exceeding the small stalkless flower clusters, crowded at the upper pairs of leaves. Corolla purple, scarcely $3 / 8$ in. long. In fields and waste places. New Brunswick and Ontario to Kentucky and westward. August. Fig. 760 .

76r. Stem leaves with an obvious and distinct stalk, not merely narrowed to a stalk-like base, except in two Skullcaps, Nos. 778 and 779. (Mint Family continued.)

Leaves distinctly toothed (except in the Hyssop Skullcap no.

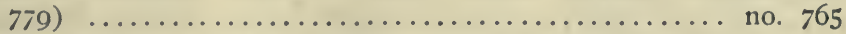

Leaves without marginal teeth, or very few and remote ones Leaves lance-oblong: plants sticky; flowers blue

Flower clusters exceeding the leaves .... Blue Curls no. 762

Flower clusters exceeded by the leaves...$\ldots \ldots \ldots \ldots \ldots$

..................... False Pennyroyal no. 763

Leaves broadly oval; plants not sticky; flowers pink, purple or white $\ldots \ldots \ldots \ldots \ldots \ldots \ldots$. White Marjoram no. 764 762. Blue Curls. Trichostema dichotomum. A sticky, much branched annual 8-18 in. high. Leaves opposite, stalked, lance-oblong, pointed both ends, I- 3 in. long, the margins wavy, but not toothed. Flowers few in open branched clusters, much exceeding the leaves. Corolla blue, rarely pinkish or white, its stamens long protruding and curved. In dry places. Maine to Florida, and westward. July-September. Fig. 762. A related species, $T$. lineare, has narrowly linear leaves, and is found in dry sandy places from Conn. along the coast to Georgia. 

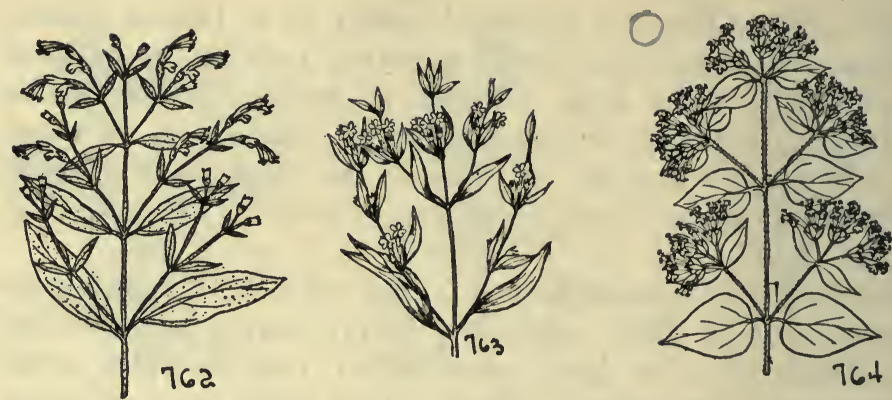

763. False Pennyroyal. Isanthus brachiatus. An erect, branched sticky annual 8-20 in. high. Leaves stalked, lanceoblong, pointed both ends, especially at the tip, I-2 in. long. Flowers few, in open short-stalked clusters among the upper leaves, and exceeded by them. Corolla blue, about $1 / 4 \mathrm{in}$. long, without the protruding stamens of No. 762. In moist sand. Quebec and Ontario to Georgia, and westward. August. Fig. 763.

764. Wild Marjoram. Origanum vulgare. An erect slender perennial, Eurasian weed, I-2 ft. high, covered with soft hairs but not sticky. Leaves broadly oval, stalked, rounded at the base and pointed at the tip, without teeth, $11 / 2-2$ in. long. Flowers in dense, globe-like clusters, mostly terminal. Corolla pink, purple or white. In fields and waste places. Ontario to New Jersey and Penn. August. Fig. 764.

765. Leaves distinctly toothed, except in the Hyssop Skullcap, No. 779. (Mint Family continued.)

Flower clusters overwhelmingly terminal, containing a few among the upper leaves $\ldots \ldots \ldots \ldots \ldots \ldots \ldots \ldots \ldots \ldots$ no. $77 \mathrm{I}$

Flower clusters practically all among the leaves, rarely terminal Flowers white ............. Common Hoarhound no. 776 Flowers not white Plant prostrate $\ldots \ldots \ldots \ldots \ldots \ldots$. Ground Ivy no. 767 Plants erect

Leaves cut and toothed ........... Motherwort no. 768 Leaves merely toothed 

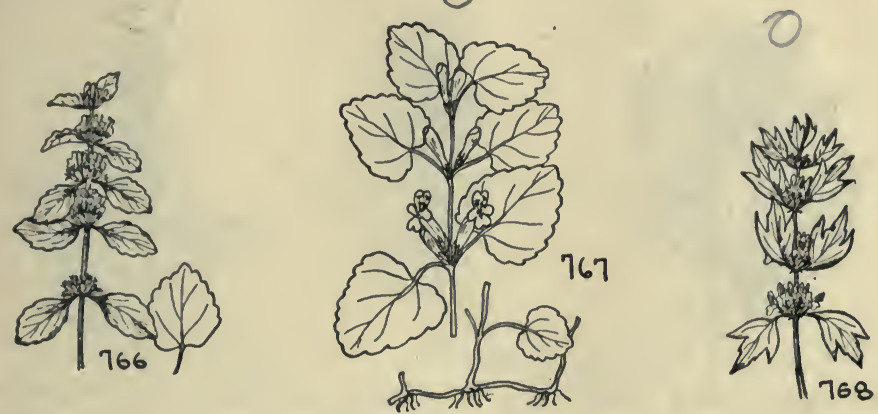

Leaf teeth sharp; plants $\mathrm{I}-3 \mathrm{ft}$.

Red Hemp Nettle no. 769

Leaf teeth rounded; plants 8-18 in. .... Henbit no. 770 766. Common Hoarhound. Marrubium vulgare. An erect Eurasian perennial with woolly stem and foliage. Leaves stalked, decidely rough, oval or nearly round, I-2 in. long, the teeth rounded. Flower clusters practically stalkless, rather dense, among the upper leaves, never terminal. Corolla white, small. In fields and waste places. Maine and Ontario to Alabama, and westward. August. Fig. 766.

767. Ground Ivy. Glechoma hederacea. (Nepeta hederacea.) A prostrate, vine-like European weed, the stems often 18 in. long. Leaves stalked, nearly round, about I in. long, the teeth rounded. Flowers few, in open clusters, exclusively among the upper leaves, never terminal. Corolla blue or violet, very conspicuously 2-lipped. Nearly throughout North America. In fields and waste places. April. Fig. 767.

768. Motherwort. Leonurus Cardiaca. An erect, coarse, stiff, Eurasian weed, $2-5 \mathrm{ft}$. high. Leaves stalked, deeply 3-5 cleft, the segments shallowly but distinctly toothed. Flower cluster dense, many-flowered, wholly among the upper leaves and much exceeded by them. Corolla about $3 / 8$ in. long, pinkish-purple, very rarely white. In fields and waste places. Common nearly through the United States. JuneSeptember. Fig. 768 .

769. Red Hemp-Nettle. Galeopsis Tetrahit. A coarse, stiffhairy Eurasian weed, I-3 ft. high, but of ten weak, and swollen below the joints. Leaves stalked, oval or lance-oval, 

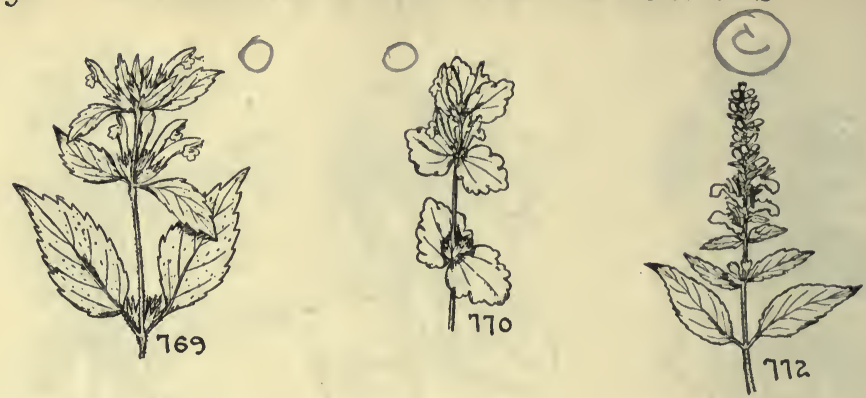

narrowed both ends, 2-5 in. long, coarsely and sharply toothed. Flowers in rather open clusters, mostly among the upper leaves, in some plants a few terminal. Corolla pinkishpurple, variegated with white, about $3 / 4$ in. long. In waste places, Newfoundland to No. Carolina and westward, especially in the uplands. June-September. Fig. 769.

770. Henbit. Lamium amplexicaule. A rather weak, slightly hairy European herb, 8-I8 in. high. Leaves nearly round, the lower long stalked, the uppermost practically stalkless, $3 / 4-1 / 2$ in. long, the teeth rounded. Flowers in small fewflowered clusters, nearly all among the upper leaves, and nearly as long as them. In some plants a few also terminal. Corolla reddish-purple, often spotted, about $3 / 4$ in. long. In waste places. New Brunswick and Ontario to Florida, and westward. March-September. Fig. 770. A white-flowered relative, L. album, has all the leaves stalked. It is a Eurasian weed found somewhat rarely from Newfoundland to No. Carolina, and westward.

771. Flower clusters overwhelmingly terminal, sometimes a few among the upper leaves. (Mint family concluded.)

Flower clusters distinctly tapering to a point ................

Flower clusters blunt, not tapering

Leaves irregularly and remotely toothed .... Heal-all no. 773 Leaves regularly toothed (without teeth in the Hyssop Skullcap, no. 779) 

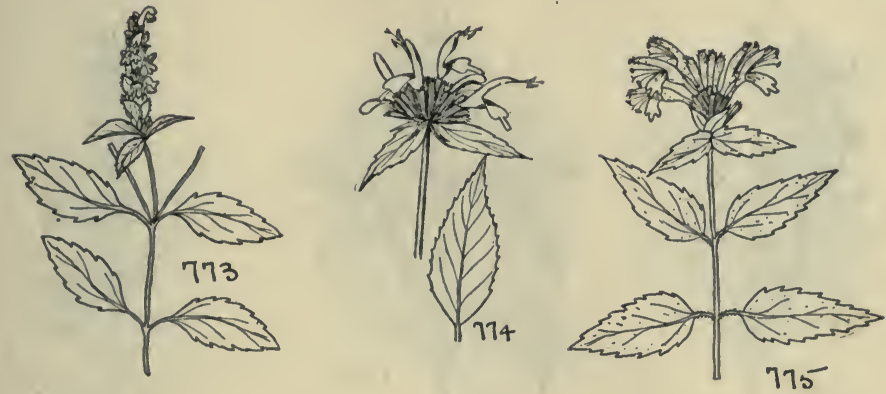

Flowers pinkish, or scarlet

Corolla scarlet, $\mathrm{r}^{\mathrm{1} / 2-2}$ in. long ...... Oswego Tea no. 774 Corolla pinkish, $1-1 \frac{1}{2}$ in. long .. Wild Bergamont no. 775 Flowers not pinkish, or scarlet

Flowers white or pale purplish ........ Catnep no. 776 Flowers blue or violet

Corolla $1 / 2$ in. long or less .. Mad-dog Skullcap no. 777 Corolla $5 / 8$ in. long or more

Leaves stalkless

Leaves toothed .......... Marsh Skullcap no. 778

Leaves without teeth .... Hyssop Skullcap no. 779 Leaves stalked .......... Downy Skullcap no. 780 772. Wood SAgE. Teucrium canadense. An erect, mostly greyish perennial, I-2 ft. high. Leaves lance-oblong, stalked, pointed both ends, $2-5$ in. long, regularly toothed. Flowers in a terminal, pointed raceme. Corolla about $3 / 4$ in. long, purplish white. In moist open places, Ontario to Florida, and westward, July. Fig. 772. A closely related coastal form, $T$. littorale, has oblong, roughish leaves, and is found along the coast from Maine to Florida.

773. HeAl-All. Prunella vulgaris. A weak or decumbent Eurasian perennial, 3-I 8 in. high. Leaves stalked, lance-oval, narrowed both ends, I-4 in. long, remotely and irregularly toothed. Flowers in a dense, blunt, thick, terminal cluster. Corolla purple or violet-purple, about $1 / 2$ in. long. In various situations, nearly throughout North America. May-October. Fig. 773 .

774. Oswego Tes. Bee Balm. Monarda didyma. A showy stout perennial 2-3 ft. high. Leaves stalked, regularly and 

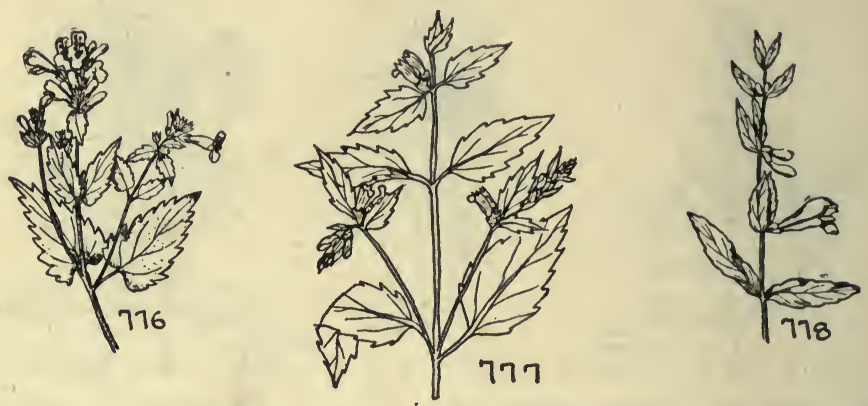

sharply toothed, lance-oval $3-6$ in. long. Flowers in a blunt, dense, terminal cluster. Corolla bright scarlet, $\mathrm{I} / 2-2$ in. long. In moist places. Quebec and Ontario to Georgia, and westward. August. Fig. 774. Often cultivated and sometimes escaping. Locally rare as a wild plant, but common in western N. Y. Much frequented by humming birds.

775. Wild Bergamot. Monarda fistulosa. A hairy perennial, 2-3 ft. high. Leaves lance-oval, $2-4$ in. long, broad at the base, tapering to a point at the tip, regularly and sharply toothed and stalked. Flowers similar to No. 774, but the corolla shorter and pinkish. In dry places, especially thickets. Maine and Ontario to Florida, and westward. July-September. Fig. 775. A related species, $M$. mollis, with pale leaves and yellowish flowers is found in the same region.

776. CatneP. Ncpeta Cataria. A densely white-woolly, very aromatic, Eurasian weed, 2-3 ft. high. Leaves stalked, triangular-oval, broad and more or less heart-shaped at the base, pointed at the tip, I-3 in. long, sharply toothed. Flowers in terminal clusters, or a few among the upper leaves. Corolla about $1 / 2$ in. long, white or pale purplish. In waste places almost throughout North America. July-October. Fig. 776. 777. MAD-DOG Skullcap. Scutcllaria lateriflora. A practically smooth, often weak perennial, 6-20 in. high. Leaves smooth, stalked, oval-oblong, I-3 in. long, the upper smaller, coarsely toothed. Flowers in somewhat loose, slightly I-sided clusters, mostly terminal, but sonetimes also among the upper leaves. Corolla blue, about $1 / 2 \mathrm{in}$. long. The remains of the flower of 

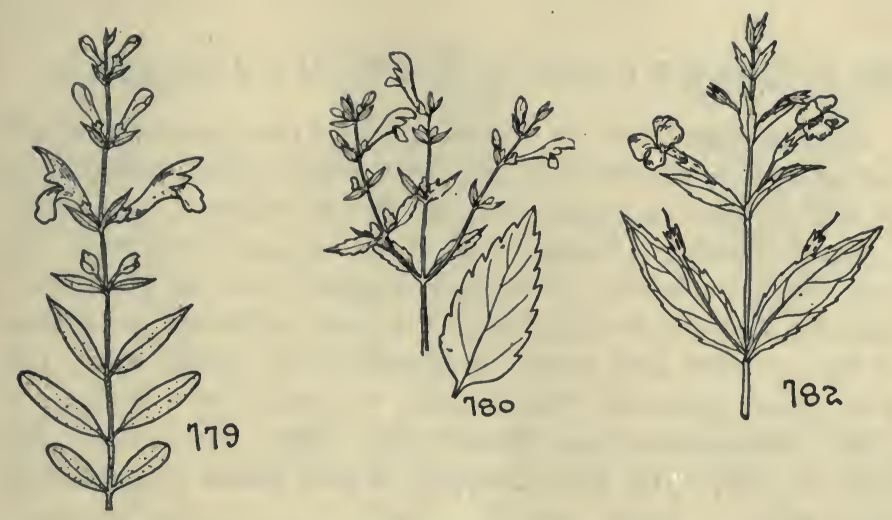

this and the next three species suggest a skullcap, hence the popular name. In wet places, almost throughout North America. August. Fig. 777.

778. Marsh Skullcap. Scutellaria galericulata. A usually branched, erect, hairy perennial, I-3 ft. high. Leaves lanceoblong, stalkless, toothed, scarcely narrowed to a broad base, $\mathrm{I}-2 \mathrm{I} / 2$ in. long, sometimes a few of the lower ones stalked. Flowers nearly solitary or in few-flowered clusters. Corolla blue, about $\mathrm{I}$ in. long. In wet places. Newfoundland to No. Carolina and westward. July-September. Fig. 778.

779. Hyssop Skullcap. Scutellaria integrifolia. A slender erect perennial, somewhat hairy, $6-20$ in. high. Leaves oval or lance-oval, I-2 in. long, without teetb, narrowed to a stalkless base. Flowers few in a mostly terminal cluster, the corolla blue, about I in. long. In woods, or thickets, Mass. to Florida, and westward; variable. June-August. Fig. 779. 780. Downy Skullcap. Scutcllaria incana. (S. canescens.) A finely white-hairy, usually branched perennial, 2-4 ft. high. Leaves stalked, lance-oblong, 3-4 in. long, sharply toothed, pointed both ends, or sometimes broad at the base. Flowers in open terminal clusters, or a few among the upper leaves, the corolla about $3 / 4$ in. long, violet-blue. In moist shade, Ontario to Florida, and westward. July. Fig. 780. There are two closely related species, differing in the degree or kind of hairiness. 
78r. FIGWORT FAMILY. SCROPHULARIACEAE.

A large family of herbs (shrubs and trees in the tropics), not aromatic, and mostly without the square or angled stems of the Mints (4-angled in the Monkey-flower, No. 782). Leaves opposite (alternate in the Purslane Speedwell, No. 793 ) in those below. Flowers in various sorts of clusters, or solitary. Corolla decidely unsymmetrical, in those below more or less I-sided, and mostly 2-lipped. Fruit mostly a dry pod. For other plants of this family, excluded here because of other characters, see Nos. 568, 569, 626, 627, 656, $657,684-687,7$ IO, 711 , and 73I. Those below may be separated thus:

Flowers in obvious, often profuse clusters $\ldots \ldots \ldots \ldots \ldots$ no. 785

Flowers solitary, or few, scarcely in clusters, if so, very sparse ones

Flowers about I in. long; plant I-3 ft. high

Monkey-flower no. 782

Flowers less than $5 / 8$ in. long; plants less than 12 in. high

Flowers white $\ldots \ldots \ldots \ldots \ldots \ldots \ldots$. Cow-wheat no. 783

Flowers bright yellow or purple

Flowers bright yellow ............. Goldenpert no. 784

Flowers pale purple ............. False Pimpernel no. 785

782. Monkey-FLower. Mimulus ringens. An erect, perfectly smooth perennial, I-3 ft. high, the stem somewhat 4-angled. Leaves opposite, stalkless, or almost stem-clasping, lanceoblong, toothed, 2-4 in. long. Flowers long-stalked, one or two from the upper leaf insertions, or solitary. Corolla very irregular, about I in. long, violet. In wet places. Nova Scotia to Virginia and westward. July-September. Fig. 782.

783. Cow-wheat. Mclampyrum lincare. A slightly hairy annual 6-Io in. high, the stem often reddish. Leaves opposite, toothless, short-stalked, lance-shaped, or lance-linear, I-2 $1 / 2$ in. long, towards the summit replaced by irregularly toothed stalkless leaves. Flowers solitary among these, the corolla cream white, tinged with yellow, about $1 / 2$ in. long. In dry places, mostly in woods, Nova Scotia to Georgia and westward. June-August. Fig. 783 .

784. Golden pert. Gratiola aurea. A low plant of wet shores, 

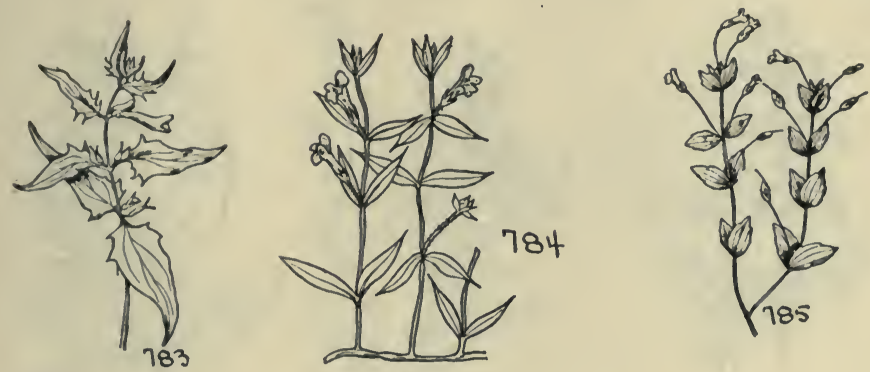

not over Io in. high, usually less. Leaves slightly sticky, toothless, or with a few minute teeth, stalkless, linear or linear-oblong, $1 / 2-I$ in. long. Flower solitary, stalked, the corolla bright yellow, about $1 / 2$ in. long, very irregular. Quebec and Ontario to Florida, mostly near the coast. JuneSeptember. Fig. 784. A related plant, G. virginiana, more frequent inland, has obviously toothed leaves, and is found in wet places almost throughout North America.

785. False Pimpernel. Illysanthes dubia. In habit and aspect very like No. 784 , but the leaves more oval and the long stalked, solitary flowers, pale purple. In wet places. Ontario and Mass. to Florida, and westward. August. Fig. 785 .

786. Flowers in obvious often profuse clusters, except in the Purslane Speedwell, No. 793. (Figwort Family continued.)

Flowers blue, white or purple ............... no. 789

Flowers not so

Flowers yellow, with a purple spot ........ Rattle no. 787 Flowers greenish-brown ............... Figwort no. 788 787. Rattle. Rhinanthus Crista-galli. A usually branched annual 6-I8 in. high, leaves opposite, stalkless, coarsely toothed, $\mathrm{I}-2$ in. long, about $\mathrm{I} / 3$ in. wide. Flowers in a small terminal, leafy cluster. Corolla very irregular, about $3 / 4 \mathrm{in}$. long, yellow, but purple spotted, and showy. In fields and on mountains. Labrador and Newfoundland, south to the mountains of New England and New York, also in the Rockies, 

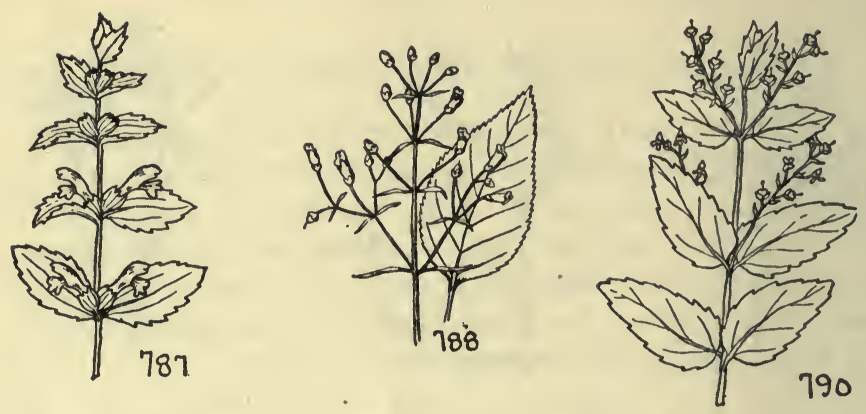

and on the coast from New Brunswick to Conn. July. Fig. 787 .

788. Figwort. Scrophularia marylandica. A tall, branching, erect perennial, $3-8 \mathrm{ft}$. high, the stem slightly angled, and the foliage strong (not mint) scented. Leaves opposite, long stalked, oval, pointed both ends, 3-12 in. long, toothed. Flowers in an open, much branched cluster. Corolla greenish-brown, about $1 / 4$ in. long. In thickets, rarely in deep woods, Maine to Georgia, and westward. August. Fig. 788. A closely related species, $S$. leporella, has rather shiny corollas and flowers about 3 weeks earlier than $S$. marylandica.

789. Flowers blue, white, or purple. (Figwort Family concluded.)

Plants prostrate, or less than 12 in. high

Flower clusters terminal

In wet places ............. American Brooklime no. 790 In dry places

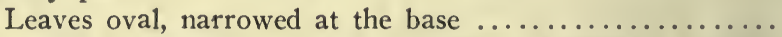
.................... Common Speedwell no. 791 Leaves oblong, not narrowed at the base ............

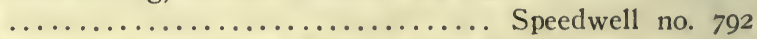
Flowers mostly solitary among the upper leaves ...........

Plants erect, mostly $\mathrm{I} / 2-4 \mathrm{ft}$. high

Flower cluster dense, not open and branched 

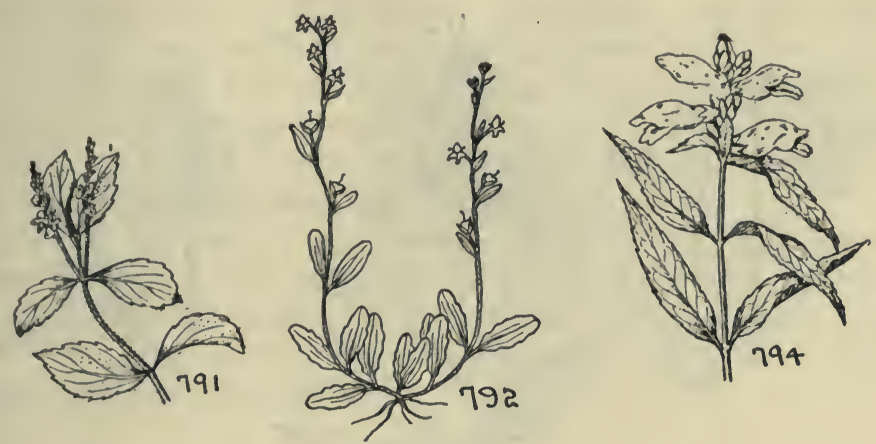

Flower cluster open, and usually branched

Stem hairy throughout ............ Beard-tongue no. 795 Only the stalks of the flower, or its cluster hairy

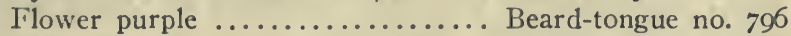
Flowers white or pinkish ......... Beard-tongue no. 797 79o. American Brooklime. Veronica americana. More or less weak, and often rooting at the joints. Leaves opposite, stalked, lance-oblong, $1 / 3$ in. long, sharply tooothed, entirely without hairs. Flowers in a terminal, branched, usually loose and few-flowered cluster. Corolla blue, or nearly white, scarcely $1 / 4$ in. long. In wet places. Newfoundland to Penn. and westward. May-August. Fig. 790. There are several related forms, some with toothed and narrower leaves and some with wholly toothless leaves.

79i. Common Speedwell. Veronica officinalis. Prostrate and hairy herb, the tips of the branches turning upward. Leaves nearly oval, wedge-shaped, and narrowed at the base, $3 / 4-2$ in. long, toothed. Flowers in slender spikes or racemes, often two at the upper leaf joints, or sometimes alternating. Corolla pale blue, about $1 / 4$ in. long. In dry woods and thickets, Nova Scotia and Ontario to No. Carolina, Tenn., and westward. May-August. Fig. 791.

792. Speedwell. Vcronica scrpyllifolia. An erect or semiprostrate plant, usually about 6 in. high. Leaves opposite, stalked, or the uppermost stalkless, rather minutely toothed, $1 / 4-1 / 2$ in. long. Flowers in sparse, few-flowered terminal clusters, the corolla blue, striped darker blue, scarcely $1 / 4 \mathrm{in}$. 

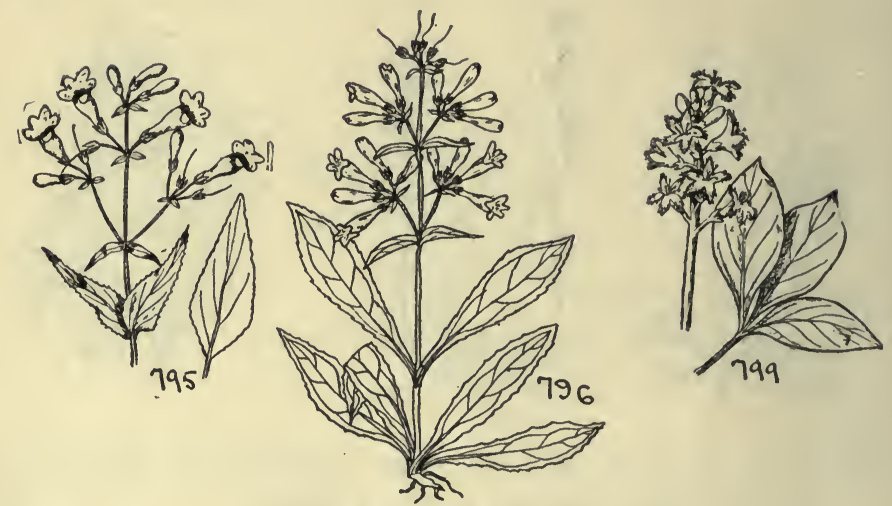

long. In fields and thickets, Labrador to Georgia, and westward. May-August. Fig. 792.

793. Purslane Speedwell. Veronica peregrina. Somewhat resembling No. 792, but the upper leaves mostly alternate, and the flowers nearly white. In waste places as a weed, also in moist sites, nearly throughout North America. May-October.

794. Turtle-head. Chelone glabra. A smooth erect herb, I $1 / 2-4 \mathrm{ft}$. high. Leaves lance-shaped, or lance-linear, short stalked, 3-6 in. long, coarsely and regularly toothed. Flowers in a close tightly packed terminal cluster, rarely more than 2 or 3 flowers open at once. Corolla white, very rarely pink, about I in. long. In wet shady places. Newfoundland to Florida, and westward. August. Fig. 794.

795. Beard-tongue. Pentstemon hirsutus. An erect perennial, the stem hairy to the base or nearly so. Leaves opposite, some stalked, the lower ones especially, others short-stalked, or stalkless, oblong or lance-oblong, toothed, 2-4 in. long. Flowers in an open, branched terminal cluster. Corolla purplish-violet, about I in. long. In thickets, rarely in woods. Maine and Ontario to Florida, and westward. June. Fig. 795 . A related plant, $P$. pallidus, has paler flowers and fewer teeth to the leaves. It grows from Conn. to Florida, and westward, mostly in moist places. 
796. Beard-tongue. Pentstemon Pentstemon. Not unlike the preceding, but not hairy throughout. Leaves narrowed to a stalk-like base, 3-6 in. long. Stalks of the flower cluster sticky-hairy. Corolla purple, about $3 / 4$ in. long. In thickets. Penn. to Florida. Kentucky and Louisiana. Often cultivated and sometimes escaping. June. Fig. 796.

797. Beard-tongue. Pentstemon Digitalis. ( $P$. laevigatus var. Digitalis.) Not unlike No. 796, but the flowers a little larger, and white or pinkish. In fields and thickets. Maine and N. Y. to Virginia, and westward, but often merely an escape from gardens. June.

798. Leaves wholly basal.

Leaves compound; leaflets 3 ............ Buckbean no. 799 Leaves not compound

Leaves broad, kidney-shaped ......... Wild Ginger no. 800 Leaves narrow, tapering to a stalk-like base Primrose no. 80I 799. Buckbean. Menyanthes trifoliata. (Menyanthaceae.) A smooth bog perennial with wholly basal, compound, long stalked leaves, with three toothless leaflets that are broad towards the tip, and narrowed to a stalk-like base. Flowers in a loose open cluster, its stalk arising from the ground, not terminal. Corolla short funnel-shaped, its 5 rather pointed lobes bearded, white or purplish. Fruit a dry pod. Greenland to Long Island, N. Y., Penn., and westward. Fig. 799. See No. 950.

80o. Wild Ginger. Asarum canadense. (Aristolochiaceae.) A stemless, hairy, aromatic perennial often covering considerable areas. Leaves roundish, or kidney-shaped, of ten with a sharp point, 4-7 in. wide, wholly basal, and relatively long stalked, toothless. Flower solitary, from between the leaf stalks, and much shorter stalked than the leaves. Petals none, but the united sepals with their 3 -lobed, brown-purple tips are petal-like. In rich woods. New Brunswick to No. Carolina, and westward. May. Fig. 80o. A closely related species, A. reflexum, has shorter and blunter sepal-tips that are recurved. It is found in similar situations from Conn. and New 

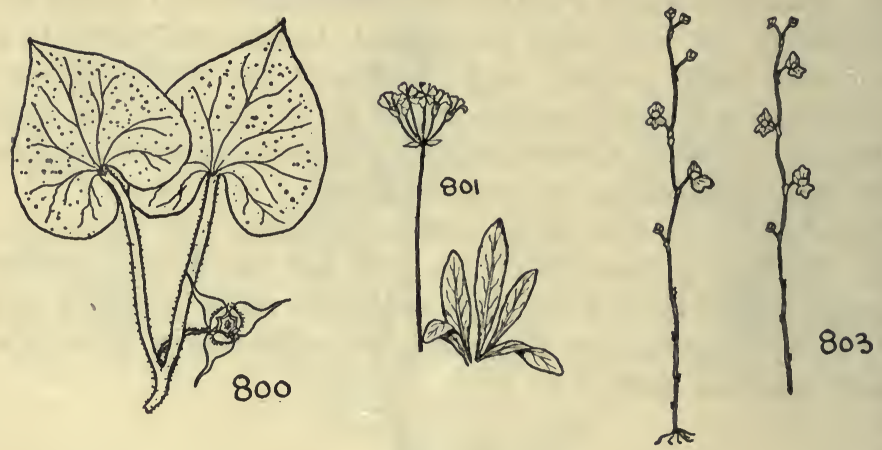

York to No. Carolina, and westward. See also No. 624. 8or. Primrose. Primula farinosa. (Primulaceae.) A slender perennial herb with a rosette of basal leaves, and a longstalked cluster of pinkish or lilac flowers with a yellow eye. Leaves green above, mealy beneath, I-4 in. long, narrowed to a stalk-like base, finely but bluntly toothed. Stalk of the flower cluster 8-12 in. high. Corolla tubular, its 5 spreading lobes notched. Fruit a dry pod. On cliffs and rocky shores. Greenland to Maine and Quebec, west to northern Michigan and Minnesota. August. Fig. 8oI. A related species, P. mistassinica, with leaves green both sides, is found from Newfoundland to central New York, west to Michigan and Saskatchewan. See also No. 466.

802. Leaves, none, or wanting at flowering time, and rarely seen, or reduced to tiny scales.

Plants of wet, sandy shores, or of meadows or bogs Flowers showy, yellow conspicuous

Flower about $1 / 4$ in. wide, not spurred

Bladderwort no. 803

Flowers about $3 / 4$ in. wide, obviously spurred ............ ......................... Bladderwort no. 804 Flowers greenish-yellow, inconspicuous, and very small ...... Plants of dry woods Screw-stem no. 805 

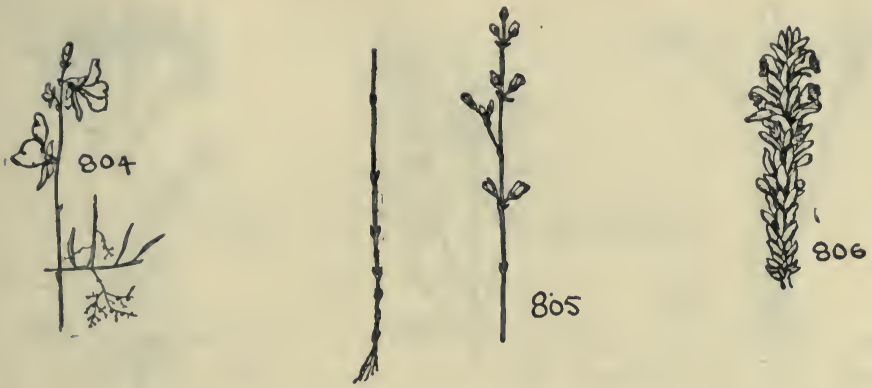

Stems club-like, scaly, brown; flowers yellow .............

Squaw-root no. 806

Stems simple or branched, not thick or club-like

Stems unbranched, sticky; flowers solitary, violet-white .. Cancer-root no. 807

Stems branched, not sticky; flowers in spikes, purplish-white 803. BladDERWort. Setiscapella subulata. (Utricularia subulata.) (Lentibulariaceae.) A delicate leafless plant with an erect, usually zig-zag flowering stalk, 3-9 in. high, upon which there are a few tiny, remote scales, and at the summit a cluster of usually 2-7 flowers, sometimes more. Flowers about $1 / 4$ in. wide, yellow, very irregular, but not spurred. In wet sand. Nantucket to Florida, west to Arkansas and Texas. Fig. 803. See also Nos. 956, 957 and 959.

804. Bladderwort. Stomoisia cornuta. (Utricularia cormitla.) (Lentibulariaceae.) Similar to No. 803 in habit, but taller, and with flowers about $3 / 4$ in. wide and rather long spurred. Edge of ponds or in bogs. Newfoundland to Florida, and westward. August. Fig. 804. See also Nos. 956, 957, and 959.

805. Screw-Stem. Bartonia virginica. (Gentianaceae.) A leafless erect, rather stiff plant of moist grassy places, 4-12 in. high, the leaves reduced to remote, tiny, opposite scales. Flowers at the summit in an open sparse cluster, greenishyellow, scarcely $1 / 10$ in. wide. Corolla tubular, its 4 lobes shallow, pointed, erect. Nova Scotia to Florida, and westward. August. Fig. 805. A related species, B. paniculata, with branching flower clusters is found in similar situations from 

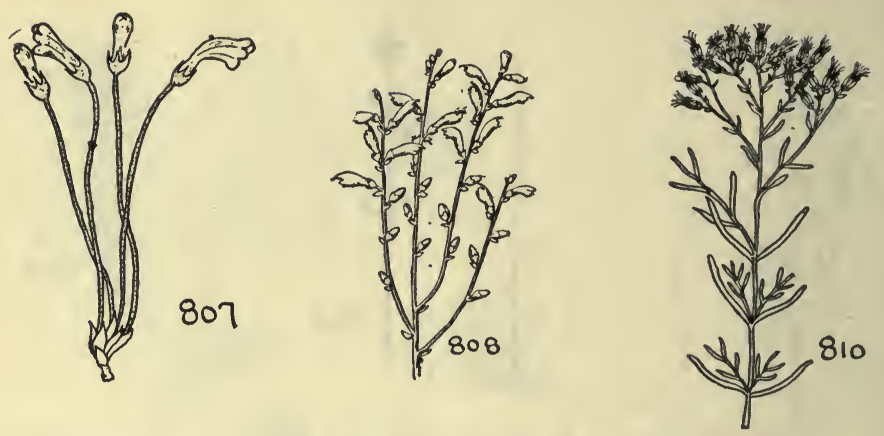

Mass. to Florida, and westward. See also Nos. 415 and 671. 806. Squaw-Root. Conopholis americana. (Orobanchaceae.) A curious leafless plant, looking like a miniature club, 3-IO in. high, covered with shining woody scales, and usually several in a cluster from one place. Flowers from between the upper scales, yellow, very irregular, and 2-lipped, about $1 / 2$ in. long, usually several in flower at one time. Parasitic on the roots of trees, especially the hemlock and beech, Maine to Florida, and westward. May-August. Fig. 806.

807. CanCER-ROot. Thalesia uniflora. (Orobanche uniflora.) (Orobanchaceae.) A leafless parasite, consisting of I-4 erect, sticky flowering stalks, arising from a scaly base, usually $4-9$ in. high, and each crowned with a solitary flower. Corolla funnel-shaped, irregular, but not 2-lipped, hairy, about $3 / 4$ in., violet-white. Parasitic on the roots of herbs. Newfoundland and Ontario to So. Carolina and Texas. May. Fig. 807. 808. BEECH-DROPS. Leptamnium virginianum. (Epifagus virginiana.) (Orobanchaceae.) A leafless, stiff, wiry, branched, usually brown-stemmed plant, with a few scales on the stem. Flowers at the ends of the branches in sparse, spike-like clusters. Corolla funnel-shaped, and irregular, but not 2-lipped, purplish white, about $1 / 2$ in. long. Parasitic on the roots of beech trees. Nova Scotia and New Brunswick to Florida, and westward. September. Fig. 808. 
No. 809

\title{
Daisy Family. Compositae
}

\author{
(Nos. 809-925.)
}

The largest family of flowering plants, comprising over ten thousand species, and over four hundred in the area covered by this book. Of these, only the most showy and conspicuous will be included. Leaves alternate, or opposite, or in some species, all basal. Flowers minute, but aggregated into heads which are usually conspicuous, such as the common Daisy, or very showy, as in the Chrysanthemum and Sunflowers. The heads are arranged in various sorts of clusters. The flowers are crowded upon a common receptacle, which is hidden while the plant is in bloom, but is obvious enough when the flower disintegrates, leaving the flat or cone-shaped receptacle quite naked. A major characteristic of this family is that each head of flowers has, just beneath it, a series of small, usually overlapping bracts, known as involucral bracts, and the collection of them is an involucre. See the Picture Glossary for a cross-section of a flower of this family.

The corolla is minute, wholly tubular in some kinds, such as Boneset, but with broad spreading rays in others, like the Dandelion. Many plants in the family have both ray flowers and tubular flowers in a single head. The rays are not separate petals as one might suspect, but are the (hypothetically) united petals of a single flower. So that each ray represents a complete flower, and the collection of rays (or of tubular flowers) constitutes the head. Among the flowers are many fine hair-like appendages, that are often attached to the seeds, as in the Dandelion, and serve as tiny parachutes for wind dispersal. A little study of the pictures of this section will soon familiarize one with the details of this family of plants, which is spread throughout the world. While 
most of our species are herbs, many in the tropics are shrubs and trees. There is one vine in this region, see No. 199. All the rest may be divided thus:

Heads exclusively of ray flowers; plants with milky juice no. 908 Heads of tubular flowers, or with tubular and ray flowers, never exclusively of ray flowers; plants without milky juice (except in the Pilewort, no. 840)

Flower heads with both tubular and ray flowers, (except in Beggar Ticks, no. 900) .................. no. 847 Flower heads exclusively of tubular flowers

Leaves alternate or basal ................. no. 8I9 Leaves opposite, or in clusters

Flowers white

Leaves in clusters of 6-10 ....... Thoroughwort no. 810 Leaves opposite

Leaves stalked .......... White Snake-root no. 8I I Leaves stalkless, or nearly so

Leaves stem-clasping ........... Boneset no. 812 Leaves not stem-clasping

Plant I-3 ft. high ... White Thoroughwort no. 8I3 Plant 3-6 ft. high .. Vervain Thoroughwort no. 8I 4 Flowers pinkish-purple; leaves in clusters ..............

Flowers green or greenish-yellow

Salt marsh plant 3-12 ft. high ...... Marsh Elder no. 816 Plants of waste places and fields

Plant I-2 ft. high; leaves not lobed .. Galinsoga no. 8I7 Plant 3-10 ft. high; leaves lobed or divided

$\ldots \ldots \ldots \ldots \ldots \ldots \ldots \ldots$.................... Ragweed no. 818

8ro. Thoroughwort. Eupatorium hyssopifolium. A roughhairy, densely branched perennial, I-2 ft. high. Leaves narrow, linear, $3 / 4-\mathrm{I} / 2$ in. long, mostly in clusters. Flowers white, tubular, the heads cylindric, about $1 / 4$ in. long, in profusely branched clusters. In dry sandy places, Mass. to Florida and Texas. August. Fig. 8Io.

8i r. White SNaḱeroot. Eupatorium urticacfolium. A smooth or sometimes sticky perennial, I-4 ft. high, and usually branched. Leaves opposite, stalked, oval, broad or rounded at the base, narrowed to a point at the tip, 3-5 in. long and sharply toothed. Flowers tubular, white, scarcely $1 / 8$ in. wide, but in profusely branched clusters. In rich woods. New Brunswick to Florida, and westward. July-November. Fig. 8I I. 

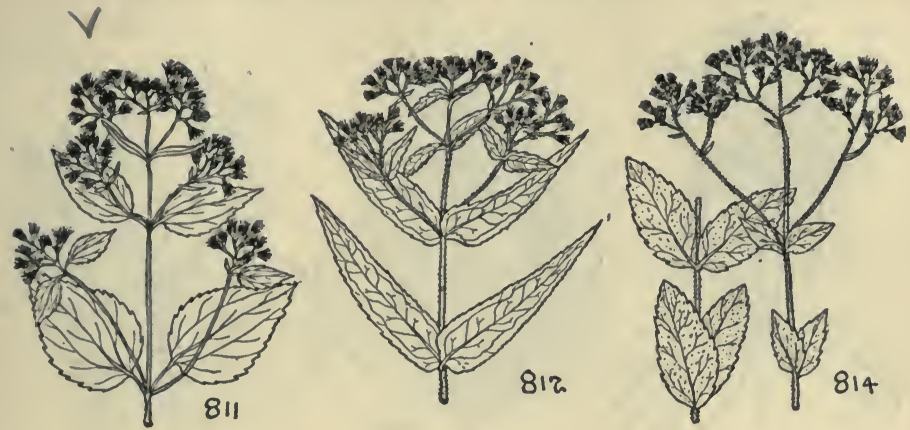

8I2. Boneset. Eupatorium perfoliatum. A coarse, rough, hairy plant, 2-6 ft. high. Leaves opposite, the stem passing through their bases, lance-oblong, 4-8 in. long, taper-pointed, and rough beneath. Flowers tubular, white, the much branched cluster of heads flattish, often $4-7$ in. wide. In moist places, Nova Scotia and New Brunswick to Florida, and westward. Very common. August. Fig. 8i2.

813. White Thoroughwort. Eupatorium album. Suggesting No. 8I4, but only I-3 ft. high, and much less hairy. In dry sand, Long Island, N. Y., to Florida, west to Tenn., Arkansas and Louisiana. August.

8i4. Vervain Thoroughwort. Eupatorium verbenacfolium. A coarse, rough-hairy perennial, 3-6 ft. high. Leaves opposite, stalkless, oval-oblong, 2-4 in. long, blunt-pointed at the tip, rounded at the base, regularly blunt toothed. Flowers tubular white, the heads about $1 / 4$ in. high, in a branched, scarcely flat-topped cluster. In moist places. Mass. to Florida, and westward. August. Fig. 8I 4. A related species, E. sessilifolium, is wholly without hairs and is found in dry woods from New England to Georgia, and westward.

8I5. JoE-Pye WeEd. Eupatorium purpurcum. Smooth or nearly smooth and 3-8 ft. tall. Leaves stalked, in clusters of $3-6$, lance-oval, coarsely and sharply toothed, pointed both ends, 4-10 in. long. Flowers tubular, pink-purple, the heads small, but arranged in immense, almost dome-like, branching clusters. In moist open places. New Brunswick to Manitoba, south to Florida and Texas; very common. August. 

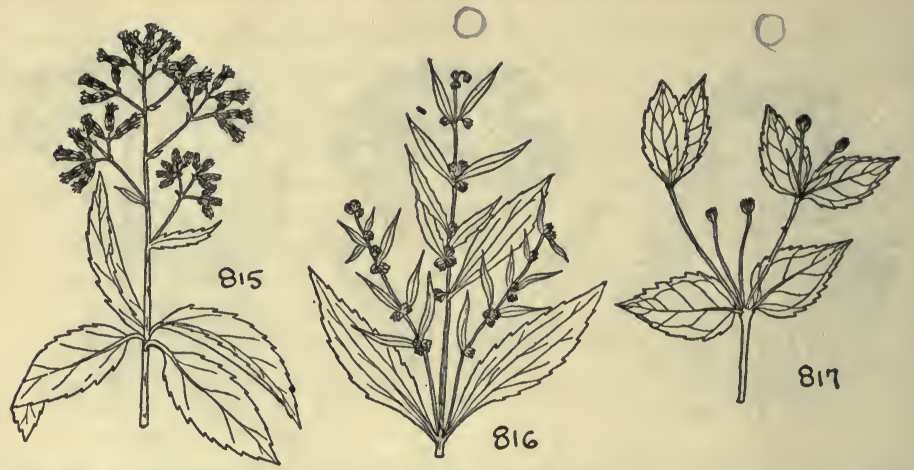

Fig. 8I 5. A closely related species, E. maculatum, has thicker leaves, and flat-topped clusters of flower heads, and is found in moist places from Newfoundland to New York and Kentucky, and westward.

8i6. Marsh Elder. Iva frutescens. (I. oraria.) A perennial, almost shrubby plant, 3-Io ft. high. Leaves thick and fleshy, oval or oval-oblong, mostly opposite, toothed, 4-6 in. long. Flowers tubular, green, in scattered, often inverted heads, mostly among the upper leaves. In salt marshes. Mass. to Florida and Texas. August. Fig. 816.

8I7. Galinsoga. Galinsoga parviflora. A tropical American annual weed, very common nearly throughout North America. Stem hairy, I-2 ft. high, branched. Leaves opposite, almost stalkless, oval, rounded at the base, pointed at the tip, toothed, I-3 in. long, rather prominently 3 -veined. Flowers tubular, greenish-yellow, the heads long stalked and solitary, or in a sparse cluster. In waste places and in gardens. JuneNovember. Fig. 817.

8I8. Ragweed. Ambrosia trifida. A rough, hairy, or sometimes smooth weed, $3^{-10} \mathrm{ft}$. high, and much branched. Leaves opposite, stalked, deeply $3^{-}$or rarely 5 -lobed, the lobes toothed, and sometimes there may be also unlobed leaves on the same plant. The lower leaves $7-$ Io in. wide. Flowers tubular, green, scattered in numerous heads arranged in long spike-like clusters. In waste places, and along river banks, nearly throughout North America. Very common. July-October. Fig. 818. A related species, A. clatior, with more finely 

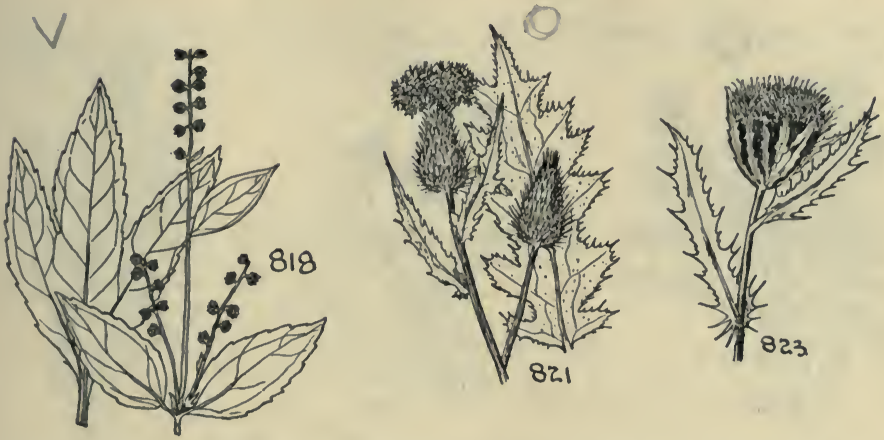

cut foliage, and rarely exceeding $5 \mathrm{ft}$. in height is also very common. Both shed immense clouds of pollen that are the cause of much hay fever.

8rg. Leaves alternate or basal.

Leaves or flower heads not prickly .............. no. 825

Leaves or flower heads, or both, prickly ...... Thistles no. 820

\section{THISTLES. CIRSIUM.}

The thistles are mostly tall prickly herbs of open fields or waste places. Leaves alternate, prickly on the margins, ribs or leaf-stalks, or in all these places; more or less cut, toothed, or wavy-margined. Flower heads large, the bracts beneath each head prickly in some species, merely bristly and not prickly in others. Of several species, those below may be separated thus:

Leaves densely white or brown-hairy on the under side

Leaves brown-hairy beneath; flower heads prickly ...........

......................... Common Thistle no. 82I

Leaves white-hairy beneath; flower heads merely bristly ......

Field Thistle no. 822

Leaves mostly green both sides, if paler beneath, not densely hairy

Flower heads $\mathrm{I}-4$ in. wide, few, yellow .. Yellow thistle no. 823

Flower heads less than $I$ in. wide, numerous, purplish-white .. Canada Thistle no. 824 

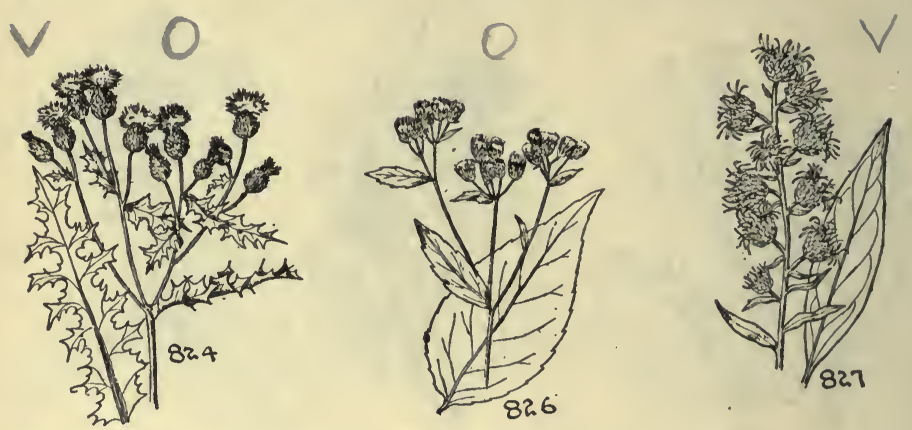

821. Common Thistle. Cirsium lanceolatum. A stout branched, more or less white-hairy European biennial, 3-5 $\mathrm{ft}$. high. Leaves lance-shaped, 3-6 in. long, very prickly, more or less deeply cut, the segments bristle-toothed, brown-hairy on the under surface. Flower heads prickly, dark purple, in a sparse, leafy cluster, or solitary, and with a few small prickly leaves below each head. In waste places, Newfoundland to Georgia and westward, July-November. Fig. 82I. 822. Field Thistle. Cirsium discolor. A rather close native relative of No. 821 , but the leaves white-hairy on the under side, and the flower heads merely bristly. In fields and roadsides. New Brunswick and Ontario to Georgia, and westward. July-November. A related plant, C. altissimum, has prickly, but undivided leaves, and is found from Mass. to Florida and Texas.

823. Yellow Thistle. Cirsium horridulum. (C. spinosissimum.) A coarse, very prickly weed, somewhat woolly when young, but green in maturity. Leaves green both sides, lanceoblong, cut or deeply lobed, prickle-tipped, 2-6 in. long. Flower heads solitary, or few, I-4 in. long, pale yellow. In dry places, Maine to Florida, and westward. July. Fig. 823. 824. Canada Thistle. Cirsium arvense. One of the commonest European weeds in northeastern America, usually branched, I-3 ft. high. Leaves green both sides, stalkless, prickly, much cut into prickle-tipped lobes, $5^{-8}$ in. long, lance-oblong. Flower heads numerous, in branched clusters, the heads less than I in. wide, and purplish-white. In fields 
and waste places, Newfoundland to Virginia, and westward. June-September. Fig. 824 .

825. Leaves or flower heads not prickly. (Daisy Family continued.) Nos. 826-846.

Flowers white, or dirty white $\ldots \ldots \ldots \ldots \ldots \ldots \ldots \ldots$ no. 839

Flowers green, yellow, or greenish-yellow ......... no. 833 Flowers pink, or purplish-pink

Salt marsh plant ........... Salt Marsh Fleabane no. 826 Not salt marsh plants

Flower heads in spike-like clusters

Flower heads distinctly stalked Button Snakeroot no. 827

Flower heads stalkless or very short stalked

Flower heads about $1 / 2$ in. thick, few .............

Blazing Star no. 828

Flower heads about $1 / 4$ in. thick, numerous .........

Flower heads in other sorts of clusters

Plants $3-9 \mathrm{ft}$. high

Leaves narrow, minutely toothed .... Ironweed no. 830

Leaves broadly oval, toothless ........ Burdock no. 83I

Plants I-2 ft. high ............... Knapweed no. 832

826. Salt Marsh Fleabane. Pluchea camphorata. A finely hairy, sticky annual, $I-21 / 2 \mathrm{ft}$. high. Leaves alternate, oval or oblong-oval, narrowed at the base, toothed, the lower ones stalked, the upper stalkless. Flowers all tubular, the heads purplish-pink, in rather sparse leafy clusters. In salt marshes, Mass. to Florida, and Texas. September. Fig. 826.

827. Button Snakeroot. Lacinaria scariosa. (Liatris scariosa.) An erect, usually unbranched and mostly hairy plant, I-4 ft. high. Leaves oblong or lance-oblong, slightly broader towards the tip, 3-8 in. long, toothless, profusely spotted, the uppermost smaller and narrower. Flower heads decidedly stalked, arranged in a long spike-like cluster, bluish-purple. In dry places, Maine and Ontario to Florida, and westward. August. Fig. 827.

828. Blazing Star. Lacinaria squarrosa. (Liatris squarrosa.) A somewhat similar plant, but lower, the leaves narrower, and the purple flower heads, which are about $1 / 2 \mathrm{in}$. wide, 

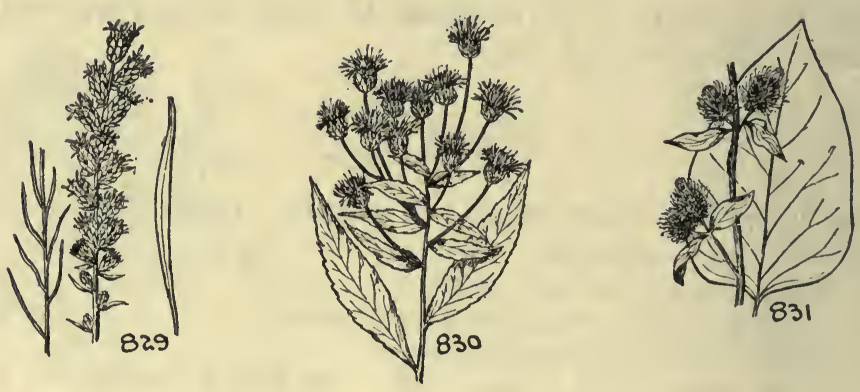

essentially stalkless, and comparatively few. In dry places, Ontario to Florida, and westward. June-September.

829. Gay Feather. Lacinaria spicata. (Liatris spicata.) Resembling both No. 827 and No. 828, but the flower heads smaller, stalkless, and very numerous, in a slender spike 6I 5 in. long. Leaves narrow, grass-like. In moist places, Ontario and Mass. to Florida, and westward. September. Fig. 829 .

830. IRONWEED. Vernonia noveboraccnsis. A coarse, very tough-stemmed weed, 3-7 ft. high. Leaves alternate, hairy or smooth, stalked, lance-linear, tapering both ends, 4-9 in. long, minutely toothed. Flowers all tubular, deep purple, with heads in a large terminal, much branched cluster. In moist open places, Mass. to No. Carolina, and westward. August. Fig. 830 .

831. Burdock. Arctium Lappa. A much branched, common weed, 4-9 ft. high. Leaves broadly oval, toothless, mostly rounded or slightly heart-shaped at the base, white-hairy on the under side, the largest often I ft. long. Heads clustered, not numerous, purple, persisting after flowering, and the bristly bracts of the head making the burs difficult to remove from clothing, or the fur of animals. In waste places, nearly throughout North America, especially the related species, A. minus. July-October. Fig. 83I. A. minus differs in having smaller heads than $A$. Lappa in which they are about $\mathrm{I}$ in. in diameter. 

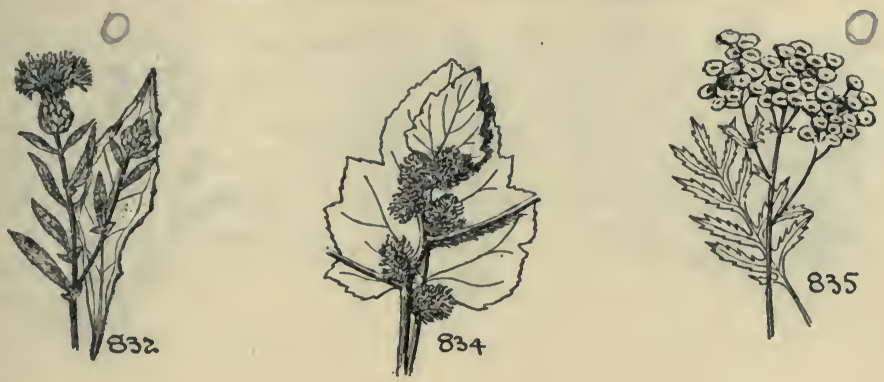

832. Knapween. Centaurca nigra. A stiff, hairy or rough European perennial, I-2 ft. high. Leaves alternate, more or less wavy margined or remotely toothed, lance-shaped or lance-oblong, essentially stalkless, 3-6 in. long. Flower heads, I in. in diameter, solitary at the ends of leafy branches, the flowers tubular, slightly fringed, rose-purple. In waste places, Newfoundland and Ontario to New Jersey and Penna. August. Fig. 832. A related plant, the Corn Flower, C. Cyanus; has blue and more fringed flowers. It is a European plant and frequently escapes from cultivation. Called also Ragged Sailor and Bachelor's-button.

833. Flowers green, yellow, or greenish-yellow.

Leaves lobed or toothed, broad; not dissected or divided ........ Leaves divided or dissected

Clot-bur no. 834

Flower heads erect, in a flat-topped cluster ... Tansy no. 835

Flower heads often drooping, in long clusters, not flat-topped Foliage densely white-hairy .... Beach Wormwood no. 836 Foliage green, or only slightly hairy

Leaves green, the divisions nearly thread-like ......... ..................... Wild Wormwood no. 837 Leaves pale, the divisions not thread-like ............. Common Wormwood no. 838

834. Clot-Bur. Xanthium commune. One of a group of species all of very similar aspect, and growing in moist open places. They are erect, or sprawling annual weeds, I-5 ft. 

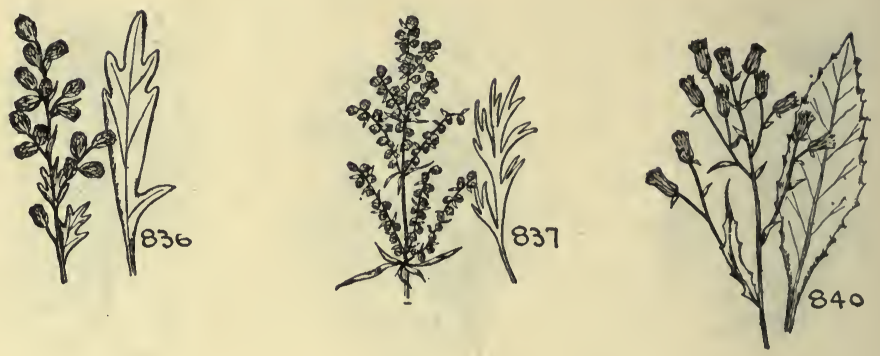

high. Leaves usually broad, roughened on the upper surface, more or less angled, often 6-9 in. wide. Flowers greenish, inconspicuous, in small heads, followed by an oblong or oval bur, which is covered with hooked prickles. Quebec and Ontario to Florida, and westward. September. Fig. 834.

835. Tansy. Tanacetum vulgare. A coarse, aromatic, mostly unbranched European herb, I-3 ft. high. Leaves divided into many sharp-pointed triangular segments, the whole leaf, especially the lower ones, often 8 in. long. Flowers tubular, yellow, in tight heads, the latter arranged in a large, branched, usually flat-topped cluster. Common in fields and waste places. Nova Scotia to No. Carolina, and westward. August. Fig. 835 .

836. Beach Wormwood, Artemisia Stcllcriana. A densely white-woolly herb, usually growing in clumps, I-2 ft. high, and strongly suggesting the garden Dusty Miller. Leaves cut into wedge-shaped segments, which are more or less roundlobed, especially towards the tip. Flowers tubular, greenishyellow, the heads grouped in small clusters which are arranged in long spike-like clusters. Sands of the sea beaches. Quebec to New Jersey. Fig. 836 .

837. Wild Wormwood. Artemisia caudata. A very leafy aromatic herb, 2-4 ft. high. Leaves green, much divided, the segments thread-like. Flowers greenish-yellow, the heads small, drooping, and very numerous, arranged in spike-like, much branched and profuse clusters. In sand and sometimes on sea beaches. Quebec to Florida, and westward. August. Fig. 837 . 
838. Сommon Wormwood. Artemisia Absinthium. Somewhat woody at the base, and 2-4 ft. high. Leaves pale, much divided, but the segments not thread-like. Flowers greenishyellow, much as in No. 837, but the clusters of heads more open, not so profuse. In waste places. Newfoundland to No. Carolina and westward, mostly as an escape from gardens. July-October.

839. Flowers white, or dirty white.

Juice milky ...................... Pilewort no. 840 Juice not milky

Foliage not covered with white felty hairs Prideweed no. 84I

Foliage covered above or below, or on both surfaces with white felty hairs

Leaves mostly basal, a few on the stem

Basal leaves $2-5$ in. long ........... Pussy-toes no. $8+2$

Basal leaves less than 2 in. long .... Cat's-foot no. 843 Leaves all on the stem, none basal

Plant prostrate, or nearly so ...... Mouse-ear no. 844

Plants erect, I-2 ft. high

Flower cluster usually flat-topped; plant not aromatic ............... Pearly Everlasting no. 845 Flower cluster usually not flat-topped; foliage with an odor suggesting Slippery-elm ............... ...................... Sweet Balsam no. 846

840. Pilewort. Erechtites hieracifolia. A coarse, milky juiced herb, I- $6 \mathrm{ft}$. high, frequently following forest or brush fires. Leaves lance-oval, essentially stalkless, 2-8 in. long, usually regularly toothed, but occasionally deeply cut also. Flowers tubular, whitish, in erect heads, which are in open, rather sparse clusters. In open places. Newfoundland and Ontario to Florida, and westward. August. Fig. 840.

841. Prideweed. Leptilon canadense. (Erigeron canadensis.) A very common weed, 6 in. $-8 \mathrm{ft}$. in height, depending upon the richness of the soil, much branched in big plants. Leaves alternate, I-4 in. long, mostly linear and toothless, hairy on the margins. Flowers a dirty white, in small heads, of which there are, in large plants, great numbers in much branched clusters. In waste places, almost throughout North America, 


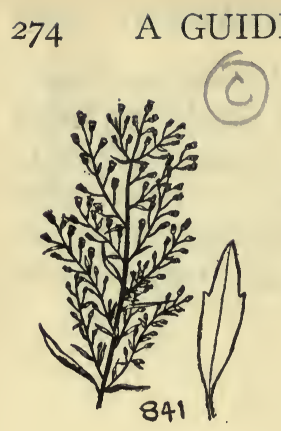

THE WILD FLOWERS

and in Europe and tropical America. June-November. Fig. 84I.

842. Pussy-toes. Antennaria plantaginifolia. A white woolly herb growing in patches and with mostly basal leaves, and a few smaller ones of the stem. Basal leaves, 2-5 in. long, oval, tipped with a soft prickle, rather prominently 3-ribbed, pale green above, white-woolly beneath. Flowers tubular, dirty white, the heads crowded in small clusters at the ends of the stem. In dry places. Quebec to Florida, and westward. May. Fig. 842. A related plant, A. Parlinii, with leaves bright green on the upper surface is found from Maine and Ontario to Virginia, and westward.

843. Cat's-foot. Antennaria neodioica. A smaller plant than No. 842 , with smaller, narrower leaves that are broadest toward the tip and narrowed into a stalk-like base. In dry places. New foundland and Quebec to Virginia and westward. May. There are several other species somewhat difficult to identify.

844. Mouse-EAr. Gnaphalium uliginosum. A nearly prostrate, white-woolly weedy plant, seldom over 6 in. high. Leaves alternate, nearly linear, pointed, $\mathrm{I}-\mathrm{I} \mathrm{I} / 2 \mathrm{in}$. long, narrowed towards the stalk-like base. Flower heads few, stalkless, clustered among the leaves at the summit of the stems, dirty white. In moist open places. Newfoundland to Virginia, and westward. August. Fig. 844 .

845. Pearly Everlasting. Anaphalis margaritacea. One of the commonest and certainly the most showy of the Everlastings. Stems I-3 ft. high, the plant pearly white-hairy. 

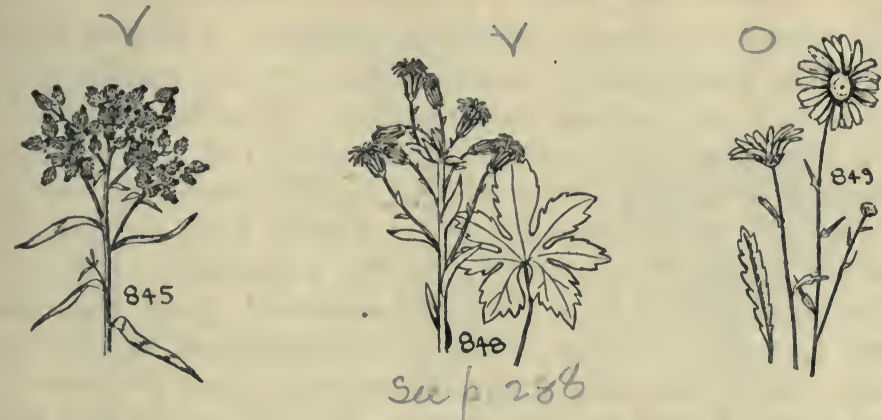

Leaves alternate, linear, 3-5 in. long, more hairy beneath than above. Flowers white, the heads in a flat-topped cluster that is often 4 in. wide. In dry places, Newfoundland to No. Carolina, and westward. August. Fig. 845 .

846. Sweet Balsam. Gnaphalium obtusifolium. (G. polycephalum.) With the general aspect of No. 845, but the bruised foliage with the odor of Slippery-elm. The flowers also are dirty-white, and the heads are in clusters that are not flat-topped. In dry places, Nova Scotia to Florida, and westward. August.

847. Flower heads with both tubular and ray flowers, except in Beggar-ticks, No. 900. (Daisy Family continued. Nos. 848-907.)

Flowers yellow (except in the Silver Rod, no. 876, and the Rose Tickseed, no. 895) ...................... no. 872

Flowers never yellow

Leaves not divided or dissected, sometimes slightly lobed, and of ten toothed $\ldots \ldots \ldots \ldots \ldots \ldots \ldots \ldots \ldots \ldots \ldots \ldots$ no. 852

Leaves divided or dissected, often much so

Flower heads on a scaly stalk; the leaves absent at flowering time .................... Sweet Coltsfoot no. 848

Flowers blooming when the leaves are present

Leaves merely divided; heads few or solitary, I-2 in. wide ............... Common White Daisy no. 849 Leaves finely dissected; heads smaller

Flower heads numerous, about $1 / 4$ in. wide $\ldots \ldots \ldots \ldots$ ......................... Yarrow no. 850 Flower heads fewer, about $3 / 4$ in. wide ............. Dillweed no. $85 \mathrm{I}$ 
848. Sweet Coltsfoot. Pctasites palmatus. A curious plant with the white-woolly under surface of the broad-angled leaves in strong contrast to the perfectly green upper surface. The leaves are never present at flowering time, but develop some weeks later. Flowers white, fragrant, clustered towards the end of a scaly stalk that arises directly from the ground. In wet places, Newfoundland to the mountainous parts of New England and New York and westward. April. Fig. 848. 849. Common White Daisy. Chrysanthemum Leucanthemum. One of the most common European plants in America, and prized for its brilliant flowers. Usually unbranched and smooth, I-I I/2 ft. high. Leaves merely deeply toothed or incised, oblong, the basal ones stalked, the stem leaves stalkless. Flower heads mostly solitary, $I-2$ in. wide, the rays white. June-October. Mostly in fields or along roadsides. Fig. 849.

850. Yarrow. Achillea Millefolium. A perennial, aromatic, Eurasian herb, I-2 ft. high. Leaves finely dissected, mostly stalked, more or less oblong in outline, the uppermost smaller, short stalked, or stalkless. Flower heads in a nearly flattopped cluster that may be 3 in. wide. Heads about $1 / 4$ in. wide, the rays mostly white, rarely pinkish. In fields and waste places, throughout North America. June-October. Fig. 850 .

851. Dillweed. Anthemis Cotula. An evil-smelling sticky European weed with finely dissected leaves. Flower heads much like No. 849, but not so large, and often more than one or two, as in No. 849. In fields and waste places, nearly throughout North America. June-October. A relative, with yellow flowers and hairy foliage, $A$. tinctoria, is found throughout North America in similar situations.

852. Leaves not divided or dissected, sometives slightly lobed, and often toothed.

This group of the Daisy Family includes mostly the Asters, and their close relatives. Of the many species found 

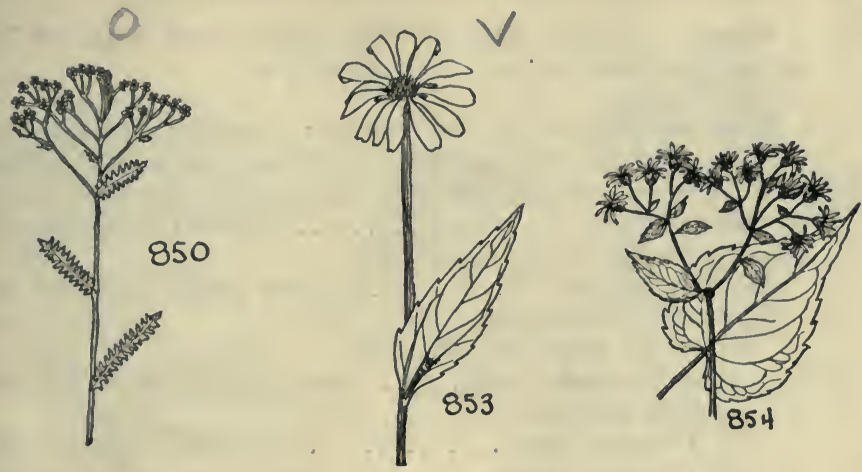

in our area, only a few can be included here, for they intergrade a good deal, many hybridize with one another, and all are difficult to identify. Those below are to be considered typical of several well-marked groups, rather than an attempt to differentiate all the technical species recognized in the Manuals. The species here included may be separated thus :

Heads, not the cluster of them, at least 3 in. wide ............

Heads not so wide

Leaves toothed, at least some of them

Flowers white

Basal leaves large and heart-shaped

Basal leaves, if any, not heart-shaped

Purple Cone-flower no. 853

Stem zig-zag; leaves tapering to the tip ..............

Stems not zig-zag

Bracts beneath the heads herbaceous and slightly recurved ............. White-topped Astor no. 856 Bracts not herbaceous; erect

Plant hairy ............. Daisy Fleabane no. 857

Plant without hairs ..... Tall White Aster no. 858

Flowers lavender, violet, or rose-purple

Flowers rose-purple; plant mostly hairy.... Skevish no. 859

Flowers violet or bluish-violet

Basal leaves large and heart-shaped

. Blue Wood Aster no. 860

Basal leaves, if any, not large and heart-shaped ....... Small Fleabane no. 86I 
Flowers lavender; stem reddish..Large-leaved Aster no. 862 Leaves not toothed, or only very slightly so

Flowers white

Stem leaves narrow, the margins parallel or nearly so; flower heads very numerous .. White Heath Aster no. 863 Stem leaves oval-pointed, the margins not parallel; flower heads fewer ................ Flat-top Aster no. 864 Flowers violet, blue, or purple

Salt marsh plant ............. Salt Marsh Aster no. 865 Not salt marsh plants

Plants of moist or wet places

Stems rough-hairy ...... New England Aster no. 866 Stems smooth

Flowers blue ............ Smooth Aster no. 867

Flowers violet ......... New York Aster no. 868

Plants of dry places

Flower heads violet, terminating the branchlets; plants mostly under I ft. high .......... Stiff Aster no. 869

Flower heads in clusters, not terminating the branchlets Flower heads in a raceme; leaves silky ........... .................... Silvery Aster no. 870 Flower heads not in racemes; leaves not silky ...... .................... Showy Aster no: 87 I

853. Purple Cone-Flower. Echinacea purpurea. (Branneria purpurea.) A stout, stiff perennial 2-5 ft. high. Leaves toothed, the lower short-stalked, the upper nearly stalkless, mostly with 3 or 5 principal veins, 3-6 in. long, about half as wide, pointed at the tip. Flower heads long stalked, about 3 in. wide, the rays purple, sometimes drooping. In moist places, Virginia to Alabama, and westward, but sometimes as a weed further north. August. The center of the flower head is cone-shaped. Fig. 853 .

854. White Wood Aster. Aster divaricatus. A very variable and common Aster in dry woods. Basal leaves oval and heart-shaped, 3-6 in. long, toothed, stalked, and rather thin. Stem leaves much smaller and with fewer teeth. Flowers white, the cluster of flower heads broad, flattish, and much branched. Flower heads about $3 / 4$ in. wide. Ontario to Georgia, and westward. September. Fig. 854 .

855. Mountain Aster. Aster acuminatus. A slender Aster, I-4 ft. high, with a noticeably zig-zag stem. Leaves oblong, gradually tapering to a narrow point, wedge-shaped and stalkless at the base, hairy on the veins beneath, $3 \frac{1}{2-5}$ in. 

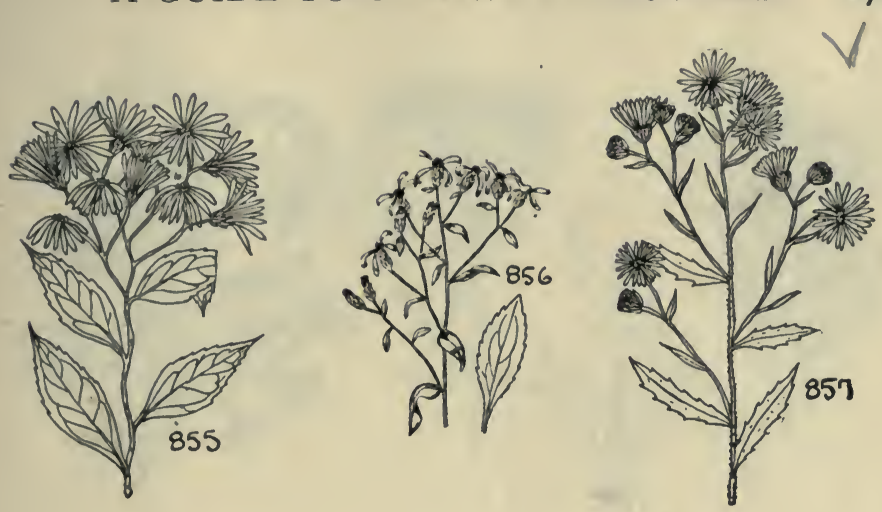

long, coarsely toothed, sometimes clustered towards the summit of the stem. Flowers white, the heads few, about I in. wide. In rich woods, Labrador and Ontario, south, mostly in the uplands, to Georgia. August. Fig. 855 .

856. White-topped Aster. Sericocarpus asteroides. A stiff perennial I-2 ft. high. Leaves oval, or slightly wider towards the tip, hairy on the margin, rather finely toothed, $2 \frac{1}{2}-4$ in. long, narrowed into a stalk-like base, the upper leaves smaller, and sometimes toothless. Flowers white, the heads few, in a flat topped cluster. The bracts beneath the flower head are green, and the tips of them slightly recurved. In dry places, Maine to Florida, and westward. August. Fig. 856. A related species, $S$. linifolius, has narrowly linear leaves, without marginal hairs, and is found in similar places.

857. Daisy Fleabane. Erigeron annuus. An erect, hairy, weedy plant, I-4 ft. high. Leaves thin, lance-oval, toothed, $21 / 2-5$ in. long, stalked, the upper stalkless, smaller and narrower. Flowers white, the heads numerous, about $3 / 4$ in. wide, the rays very numerous. In dry places. Nova Scotia to Virginia, and westward. Very common as a weed. JuneOctober. Fig. 857. A related plant, E. ramosus, has narrower stem, leaves which have no teeth. It is found from Nova Scotia to Florida, and westward, and is also very common. 858. Tall White Aster. Aster paniculatus. A smoothstemmed much branched Aster, 2-6 ft. high. Leaves oblong, 

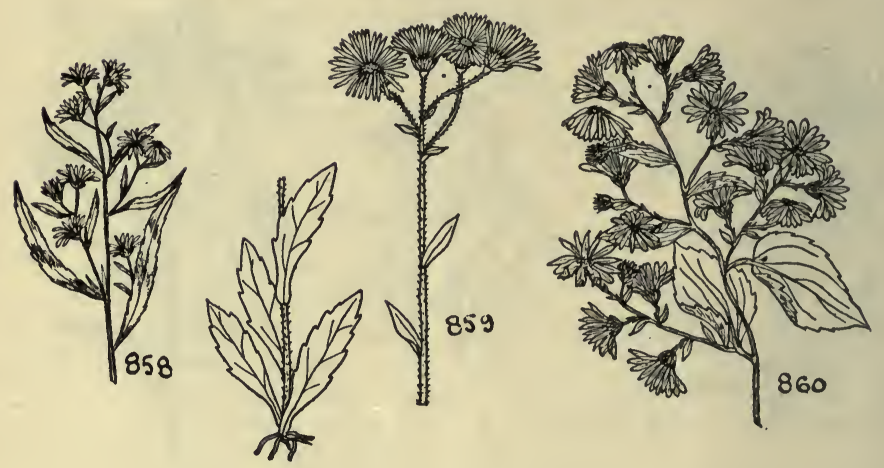

or lance-oblong, pointed at the tip, narrowed to a stalkless almost stem-clasping base, $3^{1} / 2-7$ in. long, less than $I$ in. wide, toothed, or rough-margined. Flowers white, the heads numerous, about $3 / 4$ in. wide. In moist places, New Brunswick and Ontario to Kentucky and westward. September. Fig. 858. There are several closely related species.

859. Skevish. Erigeron philadelphicus. A softly hairy, usually branched perennial, IO-20 in. high. Leaves blunt, lanceoval, or broadest towards the tip, narrowed and stalked at the base, I-3 in. long, toothed, the uppermost smaller and stem-clasping. Flowers rose-purple, the heads $I-I \frac{1}{2}$ in. wide, not very numerous. In dry places, often appearing weedy, nearly throughout North America. June. Fig. 859. A related species, E. pulchellus, with an unbranched stem and flower heads twice as large, is found from Nova Scotia to Florida, and westward.

86o. Blue Wood Aster. Aster cordifolins. A coarse, usually much branched smooth stemmed perennial, I $1 / 2-4 \mathrm{ft}$. high. Basal leaves broadly oval, deeply heart shaped at the base, long stalked, $2 \frac{1}{2}-6$ in. long, the upper stem leaves smaller and not heart shaped, toothed. Flowers blue or violet blue, rarely a little paler, in numerous heads that are scarcely $1 / 2$ in. wide. In woods and in partial shade, New Brunswick to Georgia, and westward. September. Fig. 860. 


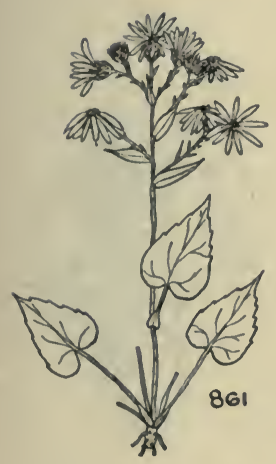

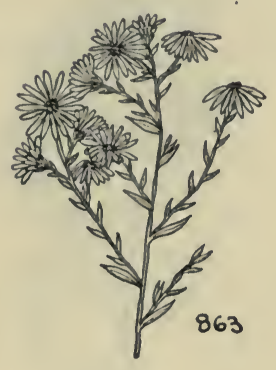

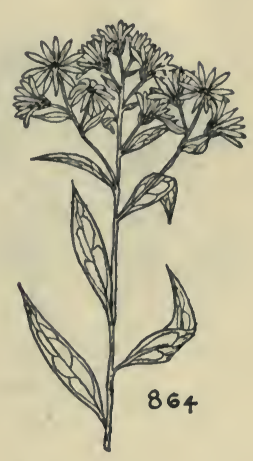

861. Small Fleabane. Aster undulatus. A rough, hairystemmed perennial, I-3. ft. high. Leaves rough both sides, toothed, hairy also on the under side, those of the stem lanceoblong, with narrowed winged bases, or some of them stemclasping, $2 \mathrm{x} / 2-5$ in. long. Basal leaves heart-shaped but usually wanting at flowering time. Flowers pale bluish-violet, about $3 / 4$ in. wide, arranged in long spreading, often I-sided clusters. In dry places, New Brunswick and Ontario to Florida and westward. September. Fig. 861. A related species, A. patens, is shorter and has oval leaves through which the stem passes. It is found in dry places from Mass. and northern New York to Florida, and westward.

862. Large-leaved Aster. Aster macrophyllus. One of the largest and coarsest of the Asters, with a rough, often reddish stem 2-3 ft. high. Basal leaves broad-oval, harsh, 3-6 in. long, stalked and toothed, the upper ones not heart-shaped and with a winged base. Flowers lavender, the heads about $3 / 4$ in. wide, in broad dome-shaped clusters. Not unlike No. 854 , but with lavender flowers. In dry woods, New Brunswick to No. Carolina, and westward. August. There are many closely related forms.

863. White Henti Aster. Aster ericoides. A much branched stout perennial, I-3 ft. high. Leaves lance-linear, or linear, essentially toothless and stalkless, 2-3 in. long. the upper much smaller. Flowers white, the heads scarcely 

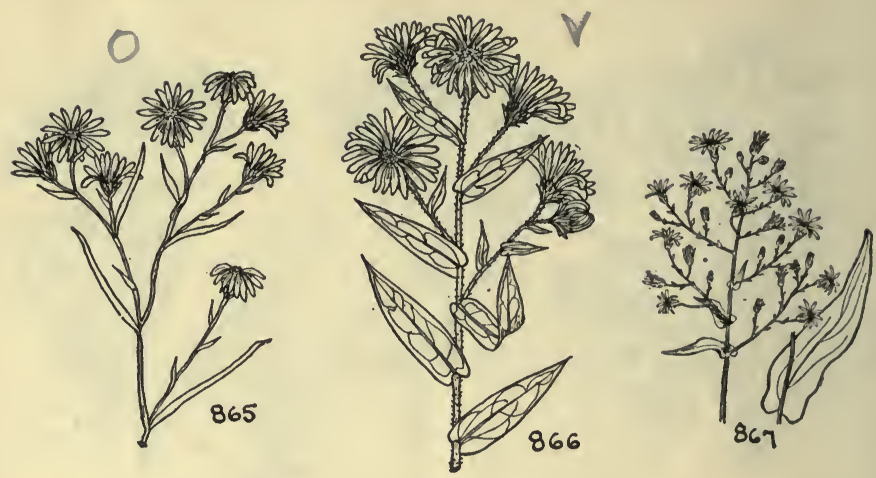

$1 / 2$ in. wide, but very numerous in much branched clusters. In dry places, nearly throughout the area, in some of its many forms. September. Fig. 863 .

864. Flat-top Aster. Doellingeria umbellata. (Aster umbellatus.) A usually smooth-stemmed, leafy perennial, 2-6 ft. high. Leaves lance-oblong, narrowed both ends, hairy on the margins, $I \frac{1}{2}-21 / 2$ in. long. Flowers white, the heads about $\mathrm{I}$ in. wide, and in small flat-topped clusters. In moist places. Newfoundland to Georgia and westward. August. Fig. 864. A related species, D. humilis, is lower and has more oval leaves. It is found from southern New Jersey to Florida and Texas.

865. Salt Marsh Aster. Aster temuifolius. A fleshy stemmed perennial Aster, not much branched, and I-2 ft. high. Leaves sharp-pointed, linear, $3 / 4-2$ in. long, toothless, stem-clasping or merely stalkless. Flowers pale lavender, or pale purple, or white, the heads few, terminating small branches. In salt meadows. Mass. to Florida. September. Fig. 865. A related species, A. subulatus, is more branched, has purplish flowers, and is found in similar situations. 866. New England Aster. Aster novae-angliae. A stout, rough-hairy perennial, mostly branched, and $2-6 \mathrm{ft}$. tall. Leaves coarse, rough, lance-oblong, toothless, $2 \frac{1}{2}-4$ in. long, stem-clasping at the base. Flowers violet-purple, the heads very showy, about $I \frac{T}{2}$ in. wide, clustered at the ends of 

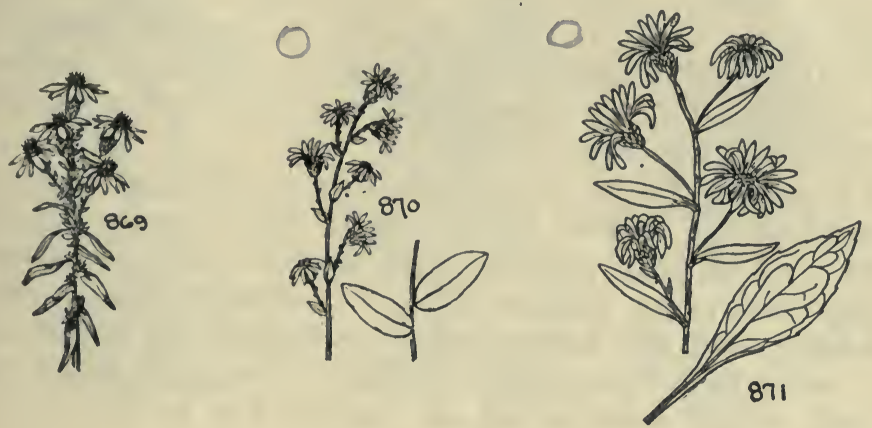

the numerous branchlets. In moist places, Quebec to No. Carolina, and westward. September. Fig. 866.

867. Sмоотн Aster. Aster laevis. A perfectly smooth branching perennial, often bluish-green, 3-6 ft. high. Leaves toothless, rarely with a few distant teeth, the upper ones stem clasping, the lower merely stalked, lance-oblong, 2-5 in. long. Flowers blue, showy, the heads about $\mathrm{I} 1 / 4$ in. wide, numerous in branched clusters. In moist or dry open places, Maine and Ontario to Louisiana, and westward. September. Fig. 867. A related species, A. concinnus, has linear leaves, and violet flowers. It is comparatively rare from Conn. to Virginia and westward.

868. New York Aster. Aster novi-belgii. Much like No. 867 , but lower and with violet flowers in heads somewhat smaller. It grows in wet places from Newfoundland to Georgia, mostly near the coast, and may be a trifle hairy towards the summit. September.

869. Stiff Aster. Ionactis linariifolius. (Aster linariifolius.) A stiff wiry plant not over 12 in. high, and usually growing in clumps. Leaves linear, standing out from the stem, hairy, sharp pointed, $1 / 2-1$ in. long, toothless. Flowers violet, the heads few, terminating the branches, and about $\mathrm{I}$ in. across. In dry places. Newfoundland to Florida, and westward. August. Fig. 86.

870. Silvery Aster. Aster concolor. Unlike any other Aster in the area in having silvery foliage, and a simple, very 
rarely branched wand-like stem, I-2 ft. high. Leaves oblong, silky-hairy, stalkless, toothless, about $3 / 4$ in. long. Flowers lilac, the heads about $3 / 4$ in. wide, in a long terminal raceme. In dry, mostly sandy places, Mass. to Florida, near the coast. September. Fig. 870.

87r. Showy Aster. Aster spectabilis. An erect, usually unbranched and stiffish Aster, I-2 ft. high. Leaves coarse, oval, 3-5 in. long, pointed, mostly without teeth, but sometimes with a few shallow ones, short-stalked. Flowers very showy, violet, the heads not very numerous, but about $\mathrm{I} 3 / 4$ in. wide. In dry sandy places, Mass. to Delaware, along the coast, rare or unknown inland. August. Fig. 87i.

872. Flowers yellow, except in the Silver Rod, No. 876 and the Rose Tickseed, No. 895 (Daisy Family continued. Nos. 873-907.)

Individual flower heads at least $\mathrm{I}$ in. wide, of ten much more .. $\ldots \ldots \ldots \ldots \ldots \ldots \ldots \ldots \ldots \ldots \ldots \ldots \ldots \ldots \ldots \ldots \ldots \ldots . \ldots \ldots$ no. 885 them may be several in. long, or wide.... Golden Rods no. 873

\section{GOLDEN RODS. SOLIDAGO AND EUTHAMIA.}

There are many species of Golden Rods and their identification is not easy, for their separation is based mostly on technical characters. As in the Asters, those below must be considered as species representative of certain groups, rather than an attempt to describe all the kinds known to grow in the area. They are all perennials with erect stems, and alternate leaves. They have yellow flowers (except in one species) in small heads, consisting of both tubular and ray flowers, and the individual head is often oblong or bell shaped. The heads are arranged in flat topped clusters in one species, in one-sided racemes in others, and in large much branched clusters in a number of species. Those below may be separated thus: 


\section{A GUIDE TO THE WILD FLOWERS}
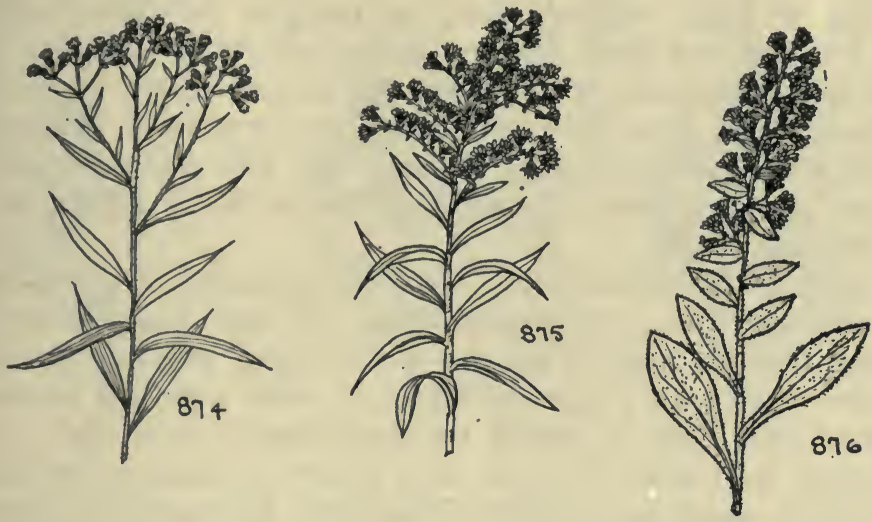

Heads in a flat topped cluster ....... Bushy Golden Rod no. 874 Heads not in a flat topped cluster

Salt marsh or sand dune plant .... Seaside Golden Rod no. 875

Not sand dune or salt marsh plants

Flowers white .................. Silver Rod no. 876 Flowers yellow

Flower heads in more or less leafy clusters

Stems hairy ............ Hairy Golden Rod no. 877

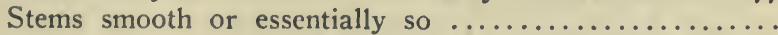

............... Large-leaved Golden Rud no. 878

Flower heads in clusters that are not leafy, or if there are any leaves among them, small and bract-like

Flower heads in conspicuously I-sided clusters

Leaves not prominently 3 -veined

Leaves toothless, anise-scented

Sweet-scented Golden Rod no. 879

Leaves not anise-scented, mostly with teeth

Stems smooth ........ Early Golden Kod no. 880 Stems hairy ............. Bitter Weed no. 88I

Leaves prominently 3 -veined

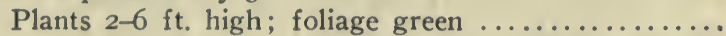
. Canada Golden Rod no. 882

Plants 8-18 in. high; foliage grayish ............. ................. Gray Golden Rod no. 883 Flower heads not in conspicuously I-sided clusters ...... Ragged Golden Rod no. 884 874. Bushy Golden Ron. Euthamia graminifolia. (Solidago graminifolia.) A stout wiry, usually much branched herb, 2$4 \mathrm{ft}$. high. Leaves lance-linear, 3-5 veined, pointed both ends, 
$1 / 2-4$ in. long, roughish along the margins and dotted with a few resinous spots. Flowers yellow, the heads scarcely $1 / 4$ in. wide, numerous in a terminal, flat topped cluster. In moist places, New Brunswick to Florida, and westward. August. Fig. 874. A related species, $A$. tenuifolia, with narrow threadlike leaves, is found in drier places from Mass. to Florida, along the coast.

875. Seaside Golden Rod. Solidago sempervirens. A stout somewhat fleshy, leafy perennial, 2-6 ft. high. Leaves lanceoval, pointed towards the tip, 3-6 in. long, stalkless or the lower ones with a short stalk, all of them with $3-5$ prominent veins. Flowers yellow, the heads nearly $1 / 2$ in. high, arranged in I-sided more or less recurved clusters. In and near salt marshes or coastal dunes, New Brunswick to Florida. August. Fig. 875 .

876. Silver Rod. Solidago bicolor. An erect usually unbranched perennial, 6-30 in. high. Leaves oblong, mostly blunt, $2^{1 / 2}-5$ in. long, the lower ones narrowed into margined stalks, the upper smaller and stalkless, all of them blunttoothed. Flowers white, the heads in a terminal, somewhat leafy, cluster. In dry places, very common from New Brunswick to Georgia, and westward. August. Fig. 876. A related species, S. caesia, with yellow flowers and a more leafy flower cluster is found from Maine and Ontario to Florida, and westward.

877. Hairy Golden Rod. Solidago hispida. Much like No. 876 , but the leaves oval, the stem hairy, and the flowers yellow. The leaves are also hairy both sides and distinctly stalked. In dry places. Nova Scotia to Penn., and westward. September.

878. LaRge-leaved Golden Rod. Solidago macrophylla. A slender stemmed perennial I-3 ft. high, with thin, smooth, sharply toothed, oval, leaves, $3^{\mathrm{T}} / 2-6$ in. long, and stalked. The upper ones narrower and stalkless. Flowers yellow, the heads in more or less leafy clusters. In rich woods, Labrador to New York, and westward, mostly in the uplands. August. Fig. 878 .

879. SweEt-Scented Golden Rod. Solidago odora. A slender 

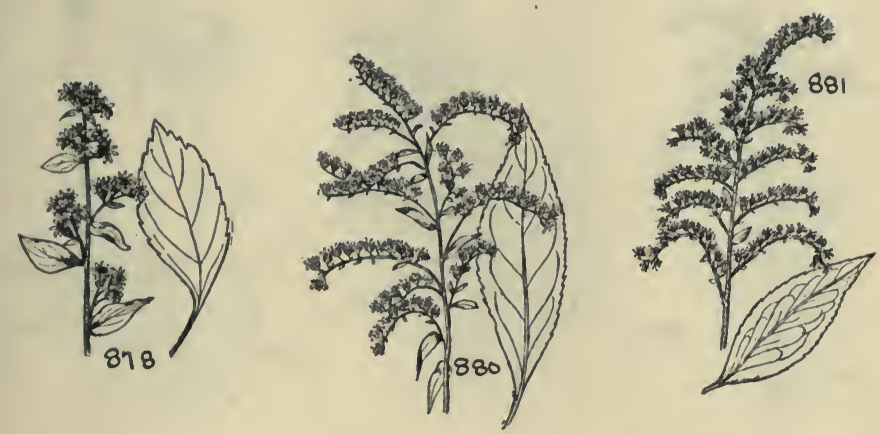

Golden Rod, unlike any of the others in having strongly anise-scented foliage, noticeable when rubbed or bruised. Leaves without teeth, lance-shaped, pointed, about 3 in. long. Flowers yellow, the heads in I-sided clusters. In dry places, especially woods, Mass. to Florida, and westward. August. 880. Early Golden Rod. Solidago juncea. A perfectly smooth, rather stout and stiff perennial, I-3 ft. high. Leaves lance-linear, toothed or not, narrowed both ends, about 5 in. long, the upper smaller and stalkless, the lower long-stalked. Flowers yellow, the heads small, arranged in conspicuously I-sided clusters. In dry places, New Brunswick to Georgia, and westward. July. Fig. 880. A related species, S. arguta, has sharply-toothed, oval leaves, an unbranched stem, and grows in rich woods from Maine to Virginia, and westward. 88r. Bitter Weed. Solidago rugosa. Perhaps the commonest Golden Rod in the area. Stem stiff, densely hairy, 2-6 ft. high. Leaves coarse, rough, hairy, sharply-toothed. lanceoblong, pointed both ends, 2-5 in. long. Flowers yellow, the heads numerous in arching I-sided clusters. In dry places, Newfoundland to Florida, and westward. August. Fig. 88I. A related species, $S$. ulmifolia, with a smooth stem, but the branches of the flower cluster hairy, is found from Maine to Georgia, and westward.

882. Canada Golden Rod. Solidago altissima. The tallest of our Golden Rods, frequently 5-6 ft. high. Leaves nar- 

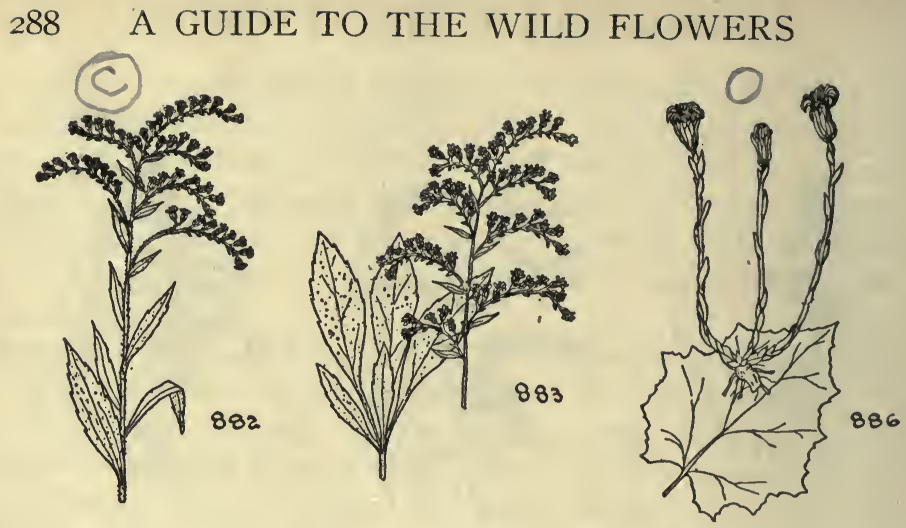

rowed both ends, the lower stalked and toothed, the upper stalkless and toothless, all of them distinctly 3-veined. Flowers yellow, the heads small, but in immense, branched clusters. In dry places, New Brunswick to Florida, and westward. September. Fig. 882.

883. Gray Golden Rod. Solidago nemoralis. A slender, usually unbranched, ashy gray, arching perennial, 8-18 in. high. Leaves finely hairy, lance-oblong, faintly 3 -veined, the lower stalked, the upper stalkless and smaller. Flowers yellow, the heads bunched in a short I-sided cluster. In dry open places, Quebec to Florida, and westward. August. Fig. 883 . 884. RagGed Golden Rod. Solidago squarrosa. An erect, almost always unbranched stout perennial, 2-5 ft. high. Leaves oblong, pointed, sharply toothed, narrowed towards a stalk-like base, but without a true leaf stalk. Flowers yellow, the heads very numerous in clusters that are not I-sided, and differing from all other Golden Rods in having green bracts below each head and with their tips all spreading and recurved. In rocky woods. New Brunswick to Virginia, and westward, mostly in the uplands. August.

885. Individual flower heads at least $\mathrm{I}$ in. in width, often much more.

Plants with leaves present at flowering time $\ldots \ldots \ldots \ldots$ no. 887

Flowers on a scaly stalk, the leaves not appearing until after the flowers $\ldots \ldots \ldots \ldots \ldots \ldots \ldots \ldots \ldots \ldots$. Coltsfoot no. 886 

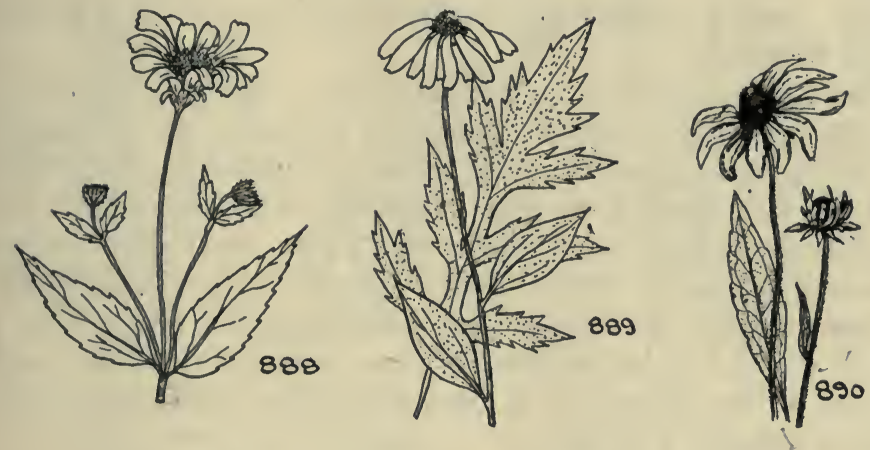

886. Coltsfoot. Tussilago Farfara. One of the earliest flowering of the Daisy Family with bright yellow solitary heads at the end of a scaly stalk. Leaves unfolding later, nearly round, angular margined, $3 \frac{\mathrm{T}}{2-7} \mathrm{in}$. broad, green above, white woolly beneath. In waste places, Nova Scotia to New York, and westward. Native of Europe. Early May. Fig. 886. See

887. Plants with the leaves present at flowering time.

Center of the flower head essentially flat or slightly convex ..

Center of the flower head conspicuously cone-like, brownish

Leaves opposite ................ False Sunflower no. 888

Leaves alternate

Leaves deeply cut or divided ... Tall Cone-flower no. 889

Leaves not cut or divided

Plants I-3 ft. tall, rough-hairy

.................... Black-eyed Susan no. 890

Plants 2-6 ft. tall, scarcely hairy .... Sneezeweed no. 89r 888. False Sunflower. Heliopsis helianthoides. A smoothstemmed branching perennial, $3-5 \mathrm{ft}$. high. Leaves in rather conspicuously opposite pairs, rarely in 3 's, oval or lanceoval, toothed, narrowed towards the base, prominently 3veined. Flowers yellow, the heads about 2 in. wide, the center cone-like. In dry open places, Ontario to Florida, and westward. 'August. Fig. 888. A related species, H. scabra, 
with rough harsh leaves, is found from Maine to New Jersey, and westward.

889. Tall Cone-Flower. Rudbeckia laciniata. A smooth, coarse, much branched herb, 3-8 ft. high. Leaves much divided, the segments both toothed and lobed, the upper leaves less divided or even toothless. Flowers yellow, the heads about 2 in. wide, the center of the head cone-shaped. Flower heads in large open branched clusters. In moist places, Quebec to Florida, and westward. Not common as a wild plant, but its cultivated form, the Golden Glow, with more numerous rays is a common garden plant and sometimes escapes. Fig. 889.

89o. Black-eyed Susan. Rudbeckia hirta. A mostly unbranched, rough-hairy biennial or annual weed, I-3 ft. high. Leaves basal and alternate, slightly toothed, mostly blunt, and with 3-5 prominent veins. Flowers yellow, the heads few or solitary, with a conspicuously dark, cone-like center. In fields, Quebec to Florida, and westward. Not native in the east, but common as a weed. July. Fig. 890 .

89r. SNeezeweed. Helcnium autumnale. A stout, mostly smooth perennial, 2-6 ft. high, conspicuous because its branches are winged from prolongation of the leaf bases. Flowers yellow, the heads very numerous, in branched clusters, the center of the head cone-like. In wet places, Quebec to Florida, and westward. Also often cultivated and sometimes escaping. August. Fig. 89r.

892. Center of flower head essentially flat or slightly convex. Plants $2 \mathrm{t} / 2$-1o ft. high ..................... no. 899 Plants $6-20$ in. high

Plants with mostly basal leaves

Leaves heart-shaped at the base.... Golden Ragwort no. 893

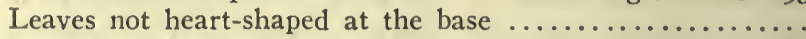

Balsam Groundsel no. 894

Plants with leaves mostly on the stem, few or none basal Ray flowers notched

Leaves linear; flowers pink ...... Rose Tickseed no. 895 Leaves broadest towards the tip; flowers yellow ......... 

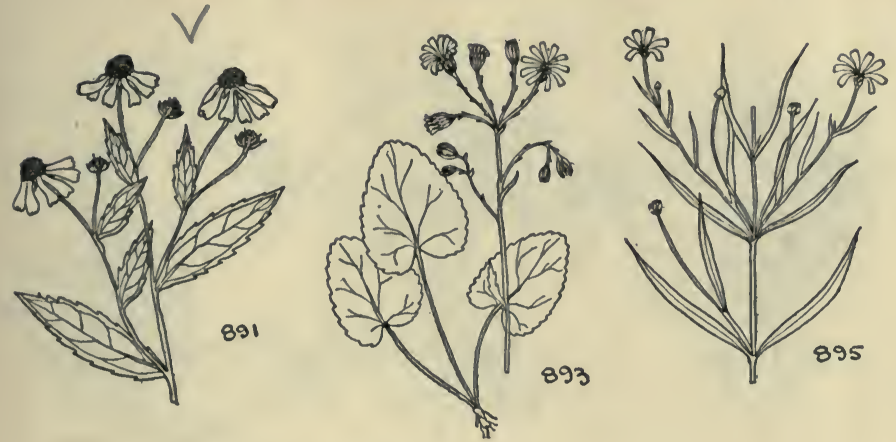

Ray flowers not notched

Leaves linear, white-woolly ...... Golden Aster no. 897 Leaves lance-oblong, hairy but not woolly ............ Golden Aster no. 898

893. Golden Ragwort. Senccio aureus. A smooth slenderstemned plant, mostly about ${ }_{5}$ in. high. Leaves nearly all basal and roundish with a heart shaped base, blunt toothed, the few stem leaves lance-oblong or linear, sharply toothed or even divided. Flowers yellow, the few heads in a long stalked terminal cluster. Center of the flower head flat. In wet places, Newfoundland to Florida, and westward. June. Fig. 893 .

894. Balsam Groundsel. Senecio pauperculus. (S. Balsamitae.) Lower than No. 893, and differing in the basal leaves not being heart shaped at the base, and often they are purplish. In dry or rocky places, Nova Scotia to No. Carolina, and westward, mostly in the uplands. June.

895. Rose Tickseed. Corcopsis rosca. A low rather weak plant of wet open places. Leaves linear, opposite, I-3 in. long, stalkless, or sometimes slightly stalked. Flowers pink, the heads often about $I^{I} / 2$ in. wide, the rays notched. Coastal Mass. to Georgia. July. Fig. 895.

896. Tickseed. Corcopsis lanceolata. A coarse, dry land relative of No. 895, but with larger yellow flowers and broader leaves. Rays of the flower head also notched. Western Ontario to Florida, and westward, but rare as a wild plant along the coast. Commonly cultivated and sometimes escaping. June. 

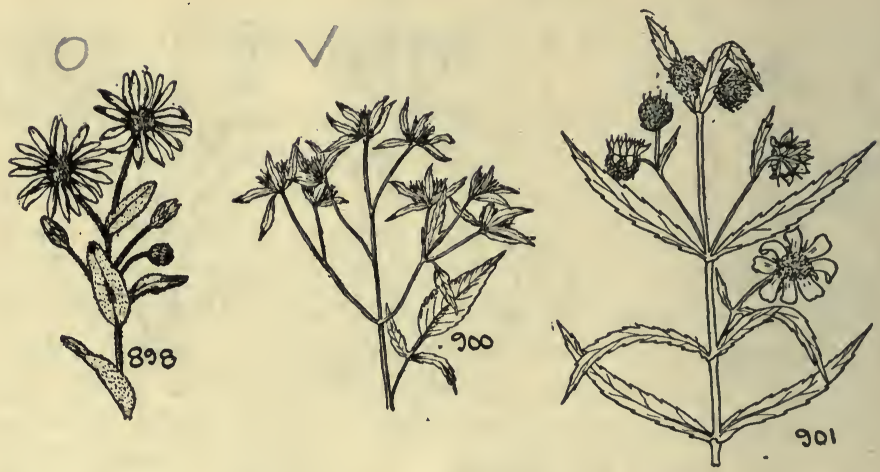

897. Golden Aster. Chrysopsis falcata. A white-woolly perennial 4-12 in. high, usually growing in clumps. Leaves linear, a little sickle-shaped, about 3 in. long. Flowers as in No. 898. In dry sandy places, Coastal Mass. to New Jersey. July.

898. Golden Aster. Chrysopsis mariana. An erect, rather stiff perennial, 6-18 in. high, usually growing in clumps. Leaves lance-oblong, softly hairy when young, often losing the hairs in age. Flowers yellow, the heads about $I \frac{1}{2}$ in. wide, the rays not notched, the flower heads not numerous, in small terminal clusters. In dry sandy soil. Long Island, N. Y. to Florida and Louisiana. August. Fig 898.

899. Plants $2 \mathrm{I} / 2-\mathrm{IO} \mathrm{ft}$. high.

Flower heads $1-I^{1 / 2}$ in. wide

Flower heads without rays, some of the leaves divided ....

......................... Beggar-ticks no. 900 Rays conspicuous; none of the leaves divided

Flower heads 2 in. wide, or more

Flower heads solitary or few

Some or all the leaves alternate

Flower heads about $2^{\mathrm{T}} / 2$ in. wide .... Elecampane no. 902

Flower heads $4-6$ in. wide .. Common Sunflower no. 903

All the leaves opposite ...... Woodland Sunflower no. 904 Flower heads in decided clusters 

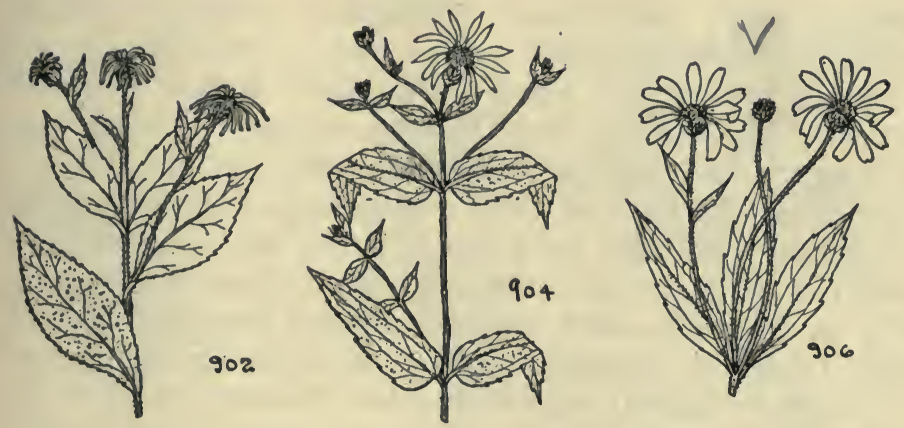

Leaves of an oval type

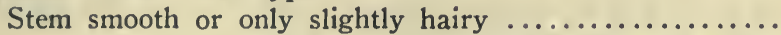

Wild Sunflower no. 905

Stem rough and hairy ...... Jerusalem Artichoke no. 906

Leaves lance-shaped or lance-oblong Giant Sunflower no. 907 900. BegGar-Ticks. Bidens frondosa. A slender stemmed annual, almost weedy, $21 / 2-3 \mathrm{ft}$. high. Leaves stalked, divided into 3-5 sharply-toothed segments, or the uppermost undivided. Flowers yellow, the heads numerous, slender stalked, and composed only of tubular flowers, followed by a small 2-pronged fruit, the prongs downwardly barbed and difficult to detach from clothing. In wet places or in fields. New Brunswick to Florida, and westward. July-October. Fig. 900. There are several close relatives. See No. $95^{2}$.

901. Bur Marigold. Bidens cermua. Not unlike No. 900, but taller, with none of the leaves divided, and with obvious yellow rays to the nodding flower head. In wet places, Nova Scotia to No. Carolina, and westward. July-October. Fig. 90I. Several closely related species are known but are difficult to identify. See No. 952 .

902. Elecampane. Inula Helcnium. A coarse European weedy plant with several, mostly unbranched stems from each root, of ten $4 \mathrm{ft}$. or more high. Leaves oblong-oval, rough above, very hairy beneath, finely toothed, 10-I 5 in. long, and stalked, the upper smaller and stalkless. Flowers yellow, the heads mostly solitary, about 3 in. wide. In fields and roadsides, Nova Scotia to So. Carolina, and westward. August Fig. 902 . 
903. Сомmon Sunflower. Helianthus annums. A rough, coarse, stiff-haired annual $3-6$, or even io $\mathrm{ft}$. high. Leaves generally alternate, the lower ones opposite, stalked, 3-veined, broadly-oval, 8-20 in. long. Flowers yellow, the heads solitary or rarely a few, at least 4 in. wide, and in cultivated, specimens, often a foot wide. As an escape from cultivation in the east, but wild on prairies in the west. August.

904. Woodland Sunflower. Helianthus divaricatus. A slender, mostly unbranched, smooth-stemmed perennial, 2-6 ft. high. Leaves all opposite, standing out rather straight, lanceoval or lance-shaped, toothed, 3-veined, distinctly rough above and hairy beneath. Flowers yellow, the heads often solitary or a very few, long stalked. In dry woods, Maine to Florida and westward. Very common. August. Fig. 904.

905. Wild Sunflower. Helianthus decapetalus. Suggesting No. 904, but the yellow flower heads in decided clusters, the leaves alternate and opposite, and the leaf base merging into a winged stalk. In moist places, Quebec to Georgia, west to Michigan and Kentucky. August.

9o6. Jerusalem Artichoke. Helianthus tuberosus. A stout perennial with considerably thickened edible rootstocks. Stem rough and hairy, 6-1o ft. high. Leaves opposite and alternate, oval or oval-oblong, long-stalked, toothed, $2 \frac{1}{2}-5$ in. long. Flowers yellow, the heads in long stalked clusters, and about $3 \frac{1}{2}$ in. wide. In waste places, New Brunswick to Georgia, and westward, mostly as an escape from cultivation. September. Fig. 906. Neither an artichoke nor from Jerusalem.

907. Giant Sunflower. Helianthus giganteus. The tallest of our wild Sunflowers, often Io $\mathrm{ft}$. high or more, and the stem rough. Leaves alternate or opposite, prevailingly lanceshaped, essentially stalkless, $2 \frac{1}{2}-5$ in. long. Flowers as in No. 906, but slightly smaller. In wet places, Maine and Ontario to Florida, and westward. September.

908. Heads exclusively of ray flowers; plants with a milky juice. (Daisy Family concluded.) Nos. 909-925. 

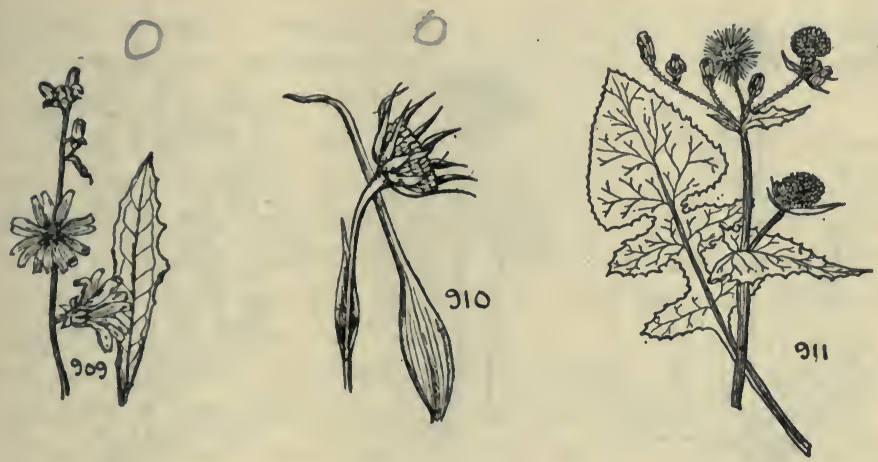

This section of the Daisy Family, because it has only ray flowers and almost universally a milky juice is often separated as the Chicory Family or Cichoriaceae. There are many species in the group, the Chickory, Lettuce, Endive, and Dandelion, being familiar examples. Those included here may be separated thus:

Flower heads mostly $3 / 4$ in. wide or less, often much less ........

Flower heads commonly $\mathrm{I}$ in. wide or more, often much more

Flowers blue or purple

Flowers blue, the heads mostly solitary or a few in stalkless clusters along the stem ............. Chickory no. 909

Flowers purple, the heads long stalked.... Oyster Plant no. 910

Flowers yellow or orange

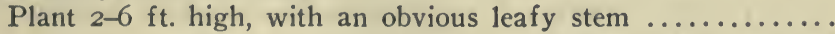

Plants lower; leaves nearly all basal

Flowers orange, the heads about 2 in. wide..Cynthia no. 912 Flowers yellow

Plant annual; flower heads about $\mathrm{I}$ in. wide ...........

Krigia no. 913

Plant perennial; flower heads about $1 \mathrm{I} / 2-2$ in. wide $\ldots .$.

909. Cincory. Cichorium Intybus. $\ddot{A}$ stiff, slightly zig-zag perennial, I-3 ft. high, the stem slightly hairy and much branched. Basal leaves mostly on the ground, much divided, long stalked, and the upper stem leaves very much smaller, stalkless and stem-clasping. Flowers usually blue, rarely purple or white, the heads few in stalkless clusters along the 

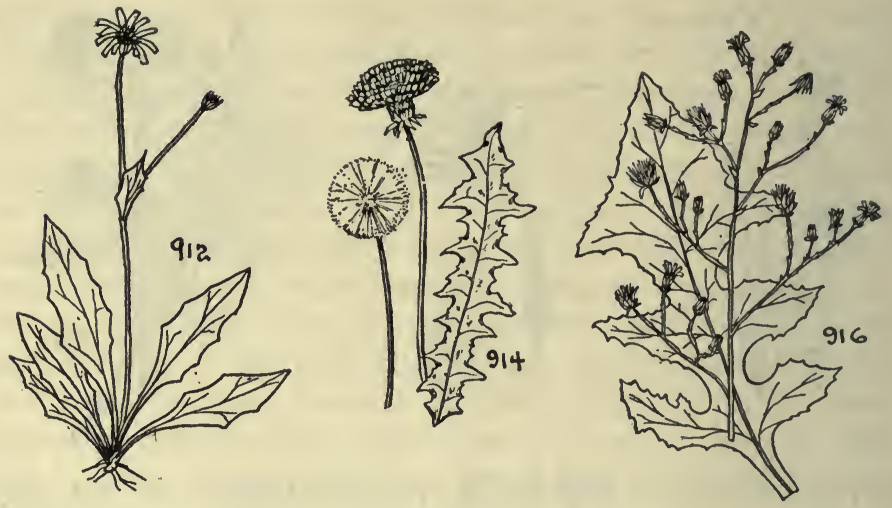

stem, or solitary and essentially stalkless, about $\mathrm{I} / 2$ in. wide. Common as a weed nearly throughout the area. Native of Europe. August. Fig. 909.

9io. Oyster Plant. Tragopogon porrifolius. A curious stiff European plant, I-4 ft. high, with lance-linear, toothless leaves. Flowers purple, the heads on hollow, thickened stalks. The bracts beneath each flower head much exceed the rays and are long, slender and pointed. In fields and waste places, mostly as an escape from cultivation, Ontario to No. Carolina and westward. June-October. Fig. 9I0. A related species with yellow flowers, $T$. pratensis, is found in similar situations.

9i r. Sow-tinistle. Sonchus oleraceus. A mostly unbranched erect stiff, annual weed, 2-6 ft. high. Lower leaves much cut or incised, the segments toothed with almost spiny teeth, and the terminal leaf-segment almost triangular. Upper stem leaves deeply divided, stem-clasping at the base. Flowers yellow, the heads about 2 in. wide, and usually numerous. Common nearly throughout North America. Native of Europe. June-October. Fig. 9I I.

912. Cynthis. Cynthia virginica. (Krigia amplexicaulis.) A perfectly smooth, bluish-green perennial, I-2 ft. high. Leaves all basal except one on the stem, shallowly and remotely 
toothed. Flowers orange or orange-red, the heads usually 2-6. In moist places, Southern Ontario and Mass. to Georgia, and westward. June-October. Fig. 912.

913. Krigia. Krigia virginica. Not unlike No. 912, but annual, about half the height, with a single head of yellow flowers, and the leaves all basal and deeply cut, the lobes turned backward, narrowed into winged stalks. In dry sandy soil, Maine and Ontario to Florida, and westward. MayAugust.

914. Dandelion. Leontodon Taraxacum. (Taraxacum officinale.) A bitter-leaved perennial with basal leaves and a solitary yellow flower head at the end of a hollow stalk. Leaves divided, the segments sharp pointed. A weed nearly throughout the world. March-November. Fig. 9I4.

915. Flower heads mostly $3 / 4$ in. wide or less, often much less. (Daisy family concluded.)

Tall, mostly branching herbs, $2^{1 / 2} \mathrm{ft}$. high or more

Flower heads erect

Flowers bluish-white ............. Blue Lettuce no. 916

Flowers yellow or orange

Plants smooth throughout ........ Wild Lettuce no. 917

Leaves hairy on the mid-rib ...... Wood Lettuce no. 918 Flower heads nodding

Flower heads very numerous ...... White Lettuce no. 919

Flower heads not numerous, commonly few in each cluster .. Rattlesnake-root no. 920

Lower, and often unbranched plants, 6-24 in. high; leaves mostly basal, rarely a few on the stem

Leaves wholly basal

Flowers yellow

Leaves green, not purple-veined .. Fall Dandelion no. $92 \mathrm{I}$

Leaves purple-veined .......... Rattlesnake Weed no. 922 Flowers orange-red ........... Orange Hawkweed no. 923 Some or all the leaves on the stem

Leaves basal and on the stem; stem usually hairy ......... ..................... Hairy Hawkweed no. 924

Leaves essentially all on the stem; stem smooth or with few hairs ................. Canada Hawkweed no. 925 
916. Blue Lettuce. Lactuca spicata. A smooth stout plant, 3-IO ft. high. Leaves deeply lobed, stalkless, or the lower ones with a winged stalk, the segments sharply toothed, the teeth almost prickle-tipped. Flowers bluish-white, the heads small, erect, and in large, branched clusters. In moist places, Newfoundland to No. Carolina, and westward. August. Fig. 9 I6.

9I7. Wild Letruce. Lactuca canadcnsis. Not unlike No. 9i6, but the leaves not divided, and stem-clasping at the base. Flowers yellow, the cluster of heads not so wide as in No. 9i6. In moist open places, Nova Scotia to Georgia, and westward. August.

918. Wood Lettuce. Lactuca hirsuta. Also resembling No. 9I6, but usually not so high. Leaves not divided, hairy on the midrib, the lower ones stalked, the upper stalkless and often stem-clasping. Flowers orange, the small erect heads in much branched clusters. In dry places, Maine and Ontario to Alabama, and westward. August.

9I9. White Lettuce. Nabalus altissimus. (Prenanthes altissima.) A slender erect perennial, 3-7 ft. high, the stem sometimes purplish. Leaves thin, more or less halberd-shaped in some leaves, in others on the same, plant without lobes, or sometimes deeply divided. Flowers greenish-white, or greenish-yellow, the heads nodding, numerous, in a branched cluster. In woods and thickets, Newfoundland to Georgia and westward. August. There are several closely related species. 920. Rattlesnake-Root. Nabalus trifoliolatus. (Prenanthes trifoliolata.) Not unlike No. 9I9, but the leaves usually 3divided and the segments stalked, or rarely stalkless. Upper leaves smaller and undivided. Flowers cream-white, the heads nodding in small but very profuse clusters. In dry places, Maine to Tenn., and westward. September. Fig. 920. There are several closely related species, and two stunted alpine ones that grow above timber line on the highest mountains.

921. Fall Dandelion. Apargia autumnalis. (Leontodon autumnalis.) A low smooth perennial not unlike No. 9I3 in aspect, but with smaller flower heads. Leaves narrow, cut into small lobes, or sometimes merely deeply toothed. Flowers 

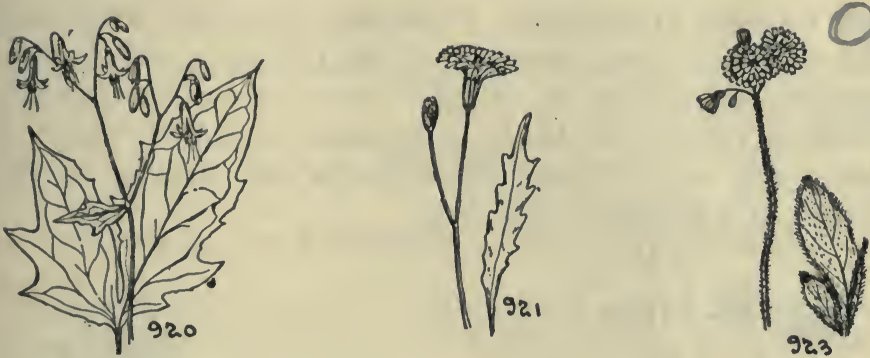

yellow, the head about $3 / 4$ in. wide, and clustered rather sparsely at the end of a naked or scaly stalk, not over 12 in. high, often less. In fields and waste places, Newfoundland and Ontario to New Jersey, Penn. and Ohio. Native of Europe and Asia. June-October. Fig. $92 \mathrm{I}$.

922. Rattlesna ke-weed. Hieraciuin venosum. A low, mostly smooth perennial with basal leaves and rarely I or 2 on the stem. Leaves usually in a rosette on the ground, of an oblong type, and purple-veined. Flowers yellow, the heads about $1 / 2-3 / 4$ in. wide, a few of them clustered at the end of the stalk. In dry woods and thickets, Maine and Ontario to Georgia, and westward. June-October.

923. Orange Hawkineed. Hieracium aurantiacum. One of the commonest and most beautiful European weeds introduced into America, not unlike No. 922 in habit, but the plant densely hairy and the gorgeous flower heads reddish-orange. In fields, often to the exclusion of anything else, especially in the uplands. New Brunswick and Ontario to New York, New Jersey and Penn. August. Fig. 923. A related European weed, $H$. pracaltum, is also very common, but has yellow flowers. It grows in similar places.

924. Hairy Haw Kweed. Hieracium Gronovii. A stiff, hairystemmed plant with basal and stem leaves that are covered with hairs. Leaves broadest towards the tip, $2 \frac{1}{2} 2-4$ in. long, stalked, the upper ones smaller and stalkless. Flowers yellow, the heads about $3 / 4$ in. wide, in an open loose cluster. In dry places, Mass. and Ontario to Florida, and westward. August. 
300 A GUIDE TO THE WILD FLOWERS

925. Canada Hawnweed. Hieracium canadense. Resembling No. 924, but leaves essentially all on the stem, and the latter smooth, or nearly so. Upper stem leaves stem-clasping. Flowers yellow, the heads in an open branched cluster. In dry woods and thickets, Nova Scotia and Ontario to New Jersey, and westward. Fig. 925.
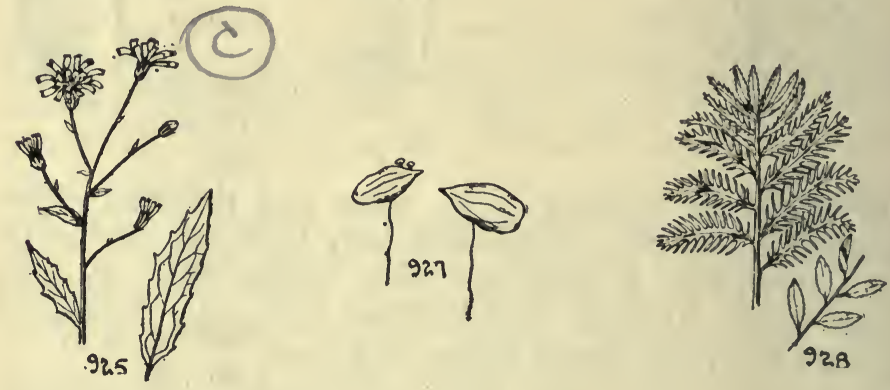
No. 926

\section{Floating or Submerged Aquatic Plants}

Aquatic plants, as here understood, differ from those treated elsewhere in the book, in having floating or submerged leaves, or both. They are not the same as those plants that grow in the water, but the structure of whose stems permits them to be erect, like the Cat-tail, and many others, scattered through various families. True aquatics are flaccid, weak, and most of them float on the surface like the IVater Lily, or live wholly submerged, like many of the Pond-weeds. All those described below are flowering plants, although some of them bear only inconspicuous or tiny flowers that escape attention unless looked for carefully. Others, like the Water Lily and Bladderworts bear conspicuous and often very beautiful flowers. Some plants that grow in or near the water have been treated in other parts of the book, largely for structural reasons. As they may be sought here the list of them follows :

No. Io. Water Plantain 258. Water Carpet 329. Marsh Marigold 382. False Mermaid 397. Yellow Water-cress
412. Swamp Loosestrife 47I. Tufted Loosestrife 520. Grass-of-Parnassus 799. Buckbean 803-804 Bladderworts

None of these are true aquatics

A few are included here in spite of the fact that their flower stalks, like the Water Lobelia, rise erect above the surface, because their leaves are wholly submerged and adapted only to underwater growth.

Perhaps the most interesting of all aquatic plants is the Eel-grass. It produces two sorts of flowers, the male which live in the depths except for one brief flight to the surface and destruction, and the female on long coiling stalks, which remain well below the surface until ready for fertilization. 


\section{A GUIDE TO THE WILD FLOWERS}

Then the spiral stalk uncoils, the tiny flower comes to the surface ready for the perfectly timed flight of the male flowers from the depths. These, by an ingenious buoyancy are suddenly released, and after reaching the female flower and fertilizing it, are carried off down stream to die. The female flower, already a mother, slowly coils up its long stem, and down near the bottom ripens the seed resulting from this marvellously timed operation.

The aquatic plants below are in many families. A great many more are known in the area than can be admitted here. Those treated may be divided into two main groups thus:

Flowers on or above the surface, relatively showy, always obvious and colored $\ldots \ldots \ldots \ldots \ldots \ldots \ldots \ldots \ldots \ldots$ no. 944

Flowers either submerged, or if above the surface, small, inconspicuous, and not brightly colored

Plants of salt water, or in brackish bays or inlets near the sea

Plants of fresh water

Leaves wholly submerged...$\ldots \ldots \ldots \ldots \ldots \ldots$......... no. 933

Some or all the leaves floating

Plant without a true stem, merely floating free on the water, often in masses ............ Duckweed no. 927 Plants with a true, often mostly submerged stem

Leaves above or on the surface, scarcely $1 / 10$ in. wide

Floating leaves sharply toothed or cut $\ldots \ldots \ldots \ldots \ldots$.

Floating leaves not toothed

Carolina Water-shield no. 929

Leaves above or on the surface; oval or lance-oval, at least $I$ in. wide

Submerged leaves narrow, scarcely $1 / 4 \mathrm{in}$. wide

Submerged leaves thread-like

Common Pondweed no. 930

Submerged leaves about $1 / 4$ in. wide Pondweed no. 93I

Submerged leaves, broad, sickle-shaped

Large-leaved Pondweed no. 932

927 Duckweed. Lemna trisculca. (Lemnaceae.) A free floating aquatic with no apparent stem, and with two tiny joined leaf-like structures from which is suspended a single tiny root, not over $1 / 4$ in. long. The leaf-like floating structures are generally oval, about $1 / 8$ in. long. Flowers almost microscopic. 

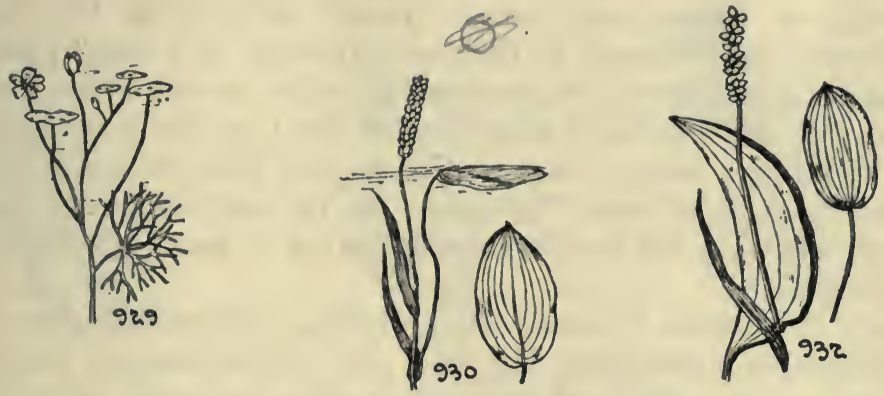

Often growing in large floating mats. Nova Scotia to New Jersey, and westward. Fig. 927. There are several other species, and some forms in another closely related genus have several instead of one thread-like root.

928. Mermaid-Weed. Proserpinaca palustris. (Haloragidaccac.) An aquatic with obvious stem rooted in mud or sand, and two sorts of leaves. The submerged ones are much divided into thread-like segments which have minute teeth and nearly always a black prickle at the stem-joint. Above surface leaves either floating or free in the air, $1-2 \frac{1}{2}$ in. long, oblong, and with sharp, rather numerous teeth. Flowers minute, without petals, and borne at the joints of the abovesurface leaves. In water or along water sides, New Brunswick to Florida, and westward. Fig. 928.

929. Carolina Water-Shield. Cabomba caroliniana. (Cabombaceac.) A slender gelatine-coated aquatic with most of its leaves submerged, and much divided into thread-like segments, but with a few floating leaves. These are oblong or oval-oblong, $1 / 2-I$ in. long, toothless, and long stalked. Flowers on long stalks, floating on the surface, whitishyellow, scarcely $1 / 2$ in. wide. In ponds or in sluggish streams. Missouri and Illinois, southward and eastward to No. Carolina and Texas. Fig. 929.

930. Сомmon Pondweed. Potamogeton natans. (Zannichelliaccae.) A rather common aquatic with two sorts of leaves, the submerged ones long and thread-like, the floating, 
oval, or oblong-oval, pointed rather abruptly at the tip, slightly heart-shaped at the base. Flowers in a small close spike, greenish and inconspicuous, which stands above the surface about an inch when the nut-like tiny fruits are ripe. Throughout North America, Europe and Asia, in ponds and slow moving streams. Fig. 930. This, the next two, and Nos. 936 and 940 , are merely representatives of many species of Pondweeds.

93I. Pondweed. Potamogeton cpihydrus. (Zannichelliaceac.) Somewhat resembling No. 930, but the submerged leaves about $1 / 4$ in. wide and obviously with a net-work arrangement of veins along the main vein, while the floating leaves are more oblong and blunt. In ponds and slow streams. Nova Scotia to Penn. and So. Carolina.

932. Large-leaved Pondweed. Potamogeton amplifolius. (Zannichelliaceae.) The coarsest and largest of all our Pondweeds. Submerged leaves, large, oval, or oblong-oval, stalked, often bent sickle-fashion, $3^{1 / 2}-7$ in. long. Floating leaves, many veined, oval, abruptly pointed, rounded at the base. In ponds and lakes. Ontario to Conn., Kentucky and westward. Fig. 932.

933. Leaves wholly submerged.

Submerged leaves slender- tape-like or thread-like

Flowers wholly submerged

Leaves tape-like, often 2-4 ft. long ...... Eel-grass no. 934

Leaves not tape-like, either long and thread-like or short and narrow

Leaves opposite or alternate

Leaves $1 / 2-1$ in. long; flowers and fruits solitary at the leaf joints ............... Water-fennel no. 935

Leaves I-2 in. long; flowers and fruits in small, stalked clusters ............. Leafy Pondweed no. 935 Leaves in clusters of 3 or more

Leaves $1 / 4-1 / 2$ in. long, undivided .. Water-weed no. 937

Leaves $1 / 2-I^{1} / 2$ in. long, forked ...... Hornwort no. 938 Flowers, or some of them, on stalks above the surface ...... Water Milfoil no. 939 Submerged leaves cup-like, the stem passing through them ...... ............................. Pondweed no. 940 

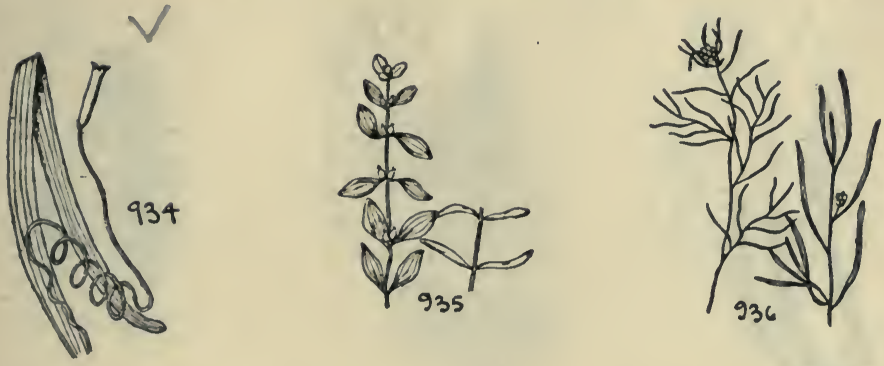

934. EeL-GRass. Vallisneria spiralis. (Vallisneriaceae.) A slender, submerged aquatic with tape-like leaves, often many feet long, and about $1 / 2$ in. wide. The length varies with the rapidity of the stream flow. For a description of the extraordinary flowers see next to the last paragraph under No. 926. In streams almost throughout North America. Occasionally in brackish water. Fig. 934. Called also wild celery and a common food of wild ducks.

935. Water-FenNel. Callitriche palustris. (Callitrichaceae.) A submerged aquatic, very rarely with floating leaves. Leaves $1 / 2-I$ in. long, slightly notched at the tip, narrow, opposite. Flowers minute, without petals, solitary at the leaf joints, the tiny fruit lobed. Usually in running water, nearly throughout the world. Fig. 935. There are several other species. 936. Leafy Pondween. Potamogeton foliosus. (Zannichelliaceae.) A submerged aquatic, the stem often $3 \mathrm{ft}$. long or more, much branched. Leaves $\mathrm{I}-2$ in. long, about $1 / 12$ in. wide, distinctly 3 -veined. Flowers greenish, inconspicuous, in small stalked clusters, followed by tiny nut-like fruits. In ponds and streams. Nova Scotia to Florida, and westward. Fig. 936. There are many closely related submerged Pondweeds. 937. Water-Weed. Philotria canadensis. (Elodea canadensis.) (Vallisneriaceae.) A submerged aquatic frequently in great masses, and in England known as Babington's Curse because of its habit of choking streams and ponds. Leaves mostly 3 or 4 at each joint, linear or oblong, $1 / 4-1 / 2$ in. long undivided, either smooth margined or with minute teeth. Flowers minute, whitish, some of them reaching the surface at matu- 

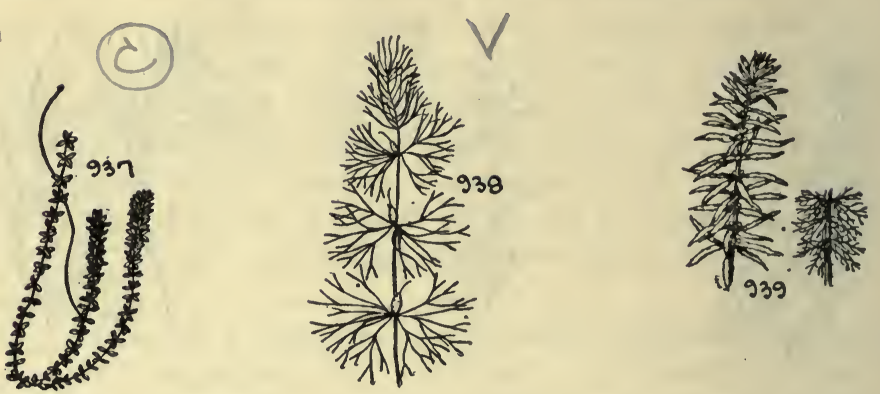

rity to float away after fertilizing the female flower. Throughout North America, and introduced into England and the Continent. Fig. 937.

938. Hornwort. Ceratophyllum demersum. (Ceratophyllaceae.) A very slender submerged water plant with threadlike leaves, $1 / 2-1 \mathrm{I} / 2$ in. long, forked, the margins minutely toothed or barbed. Flowers minute, solitary, stalkless at the leaf-insertions, followed by a nut-like fruit about $1 / 8$ in. wide. In slow streams or ponds, nearly throughout North America. Fig. 938.

939. Water Milfoll. Myriophyllum pinnatum. (M. scabratum.) (Haloragidaceae.) A submerged aquatic, except for the short spikes of flowers and a few leaves near them. Submerged leaves in 3's or 5's, or even more crowded at each joint, greatly divided into slender thread-like segments. Flowers minute, in small often interrupted spikes that appear above the surface. In ponds, Rhode Island to Florida, and westward. Fig. 939. Several closely related species occur in the area.

940. Pondweed. Potamogeton perfoliatus. (Zaninchelliaceae.) A submerged aquatic except for the spikes of flowers and fruit which appear above the surface. Leaves oval or almost cup-shaped, about $3 / 4$ in. long and wide, the stem passing through the base. Flowers greenish, inconspicuous, in small spikes, followed by tiny nut-like fruits. In ponds and streams, almost throughout North America, Europe and Asia. Fig. 940. One form of this is found also in brackish waters along the coast. 

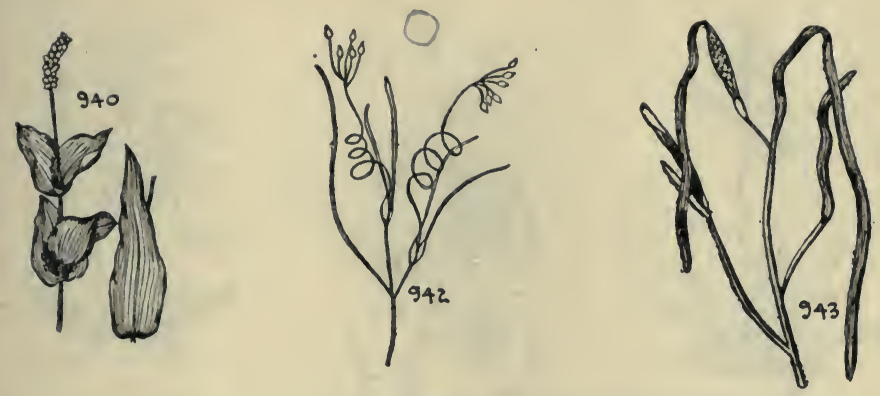

94I. Plants of salt water, or in brackish bays or inlets near the sea. (Look out also for Nos. 934 and 940.)

Leaves thread-like ..................... Ruppia no. 942 Leaves tape-like .................... Sea Wrack no. 943 942. Ruppia. Ruppia maritima. (Zannichelliaceae.) A slender often whitish-stemmed, branched, submerged aquatic. Leaves $\mathrm{I}-4$ in. long, about $1 / 12$ in. wide, sharp-pointed. Flowers minute, in stalked clusters of $4-6$, followed by small, beaked, somewhat oblique nut-like fruits about $1 / 8$ in. long, or slightly less. In the sea or in brackish water along the coast and in locally salt water in the interior. Fig. 942.

943. Sea Wrack. Zostera marina. (Zosteraceae.) A coarse much branched submerged aquatic with flattened stems. Leaves tape-like, often $3 \mathrm{ft}$. or more long, about $1 / 2 \mathrm{in}$. wide, sheathing at the base. Flowers inconspicuous, followed by tiny flask-shaped fruits. In the 'sea, almost throughout the world, in brackish waters along the coast, in locally salt water in the interior, and often washed ashore by the surf in long windrows. Fig. 943.

944. Flowers on or above the surface, relatively showy, always obvious and colored.

Flowers yellow, or purple, or rose-pink ........... no. 95 I

Flowers blue or white

Flowers blue, on an erect, hollow, scaly stalk 

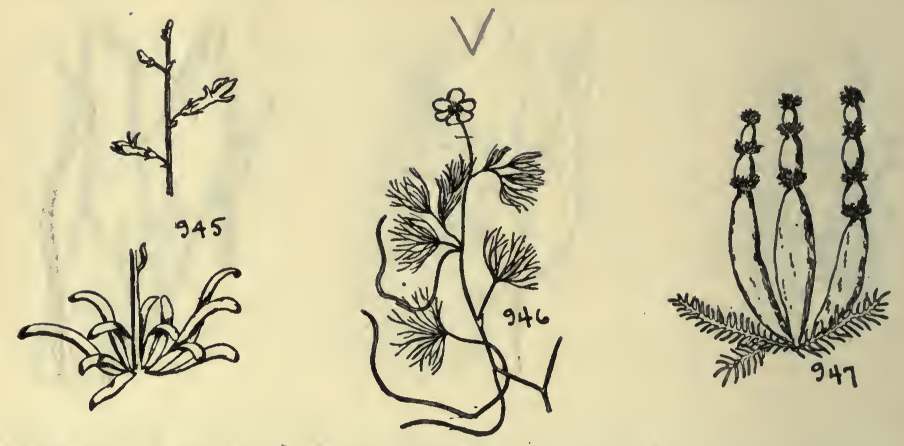

Flowers white

Leaves wholly submerged

Flowers solitary, blooming on the surface ............

Water Crow foot no. $946^{\circ}$

Flowers in a cluster, on a hollow erect stalk, blooming

above the surface ............. Featherfoil no. 947

Leaves floating

Leaves divided or cleft ......... Water-cress no. 948 Leaves undivided

Flowers 2-4 in. wide ........... Water Lily no. 949

Flowers $1 / 2-3 / 4$ in. wide ...... Floating Heart no. 950

945. Water Lobelia. Lobelia Dortmanna. (Lobeliaceae.) A perfectly smooth aquatic growing in fairly shallow water. Leaves in a submerged rosette, spongy, divided by a partition, $\mathrm{I}-4$ in. long, and about $\mathrm{I} / 4$ in. thick. From this rosette arises a scaly stalk which comes out above water and is crowned by a small cluster of irregular blue flowers, the tubes of which are about $3 / 8$ in. long. Along pond edges. New Brunswick and Nova Scotia to New Jersey, and westward. August. Fig. 945. See No. 628 for the species growing on land.

946. Water Crowfoot. Batrachium tricophyllum. (Ranunculus aquatilis var. capillaccus.) (Ranunculaceac.) A wholly submerged aquatic except for the flower which floats on the surface at blooming. Leaves finely dissected. Flowers white, about $3 / 4$ in. wide, with 5 petals and followed by a short, pointed dry fruit. In quiet water. Nova Scotia to No. Carolina, and westward. August. Fig. 946. See No. 340.

947. Featherfoll. Hottonia inflata. (Primulaceae.) A 

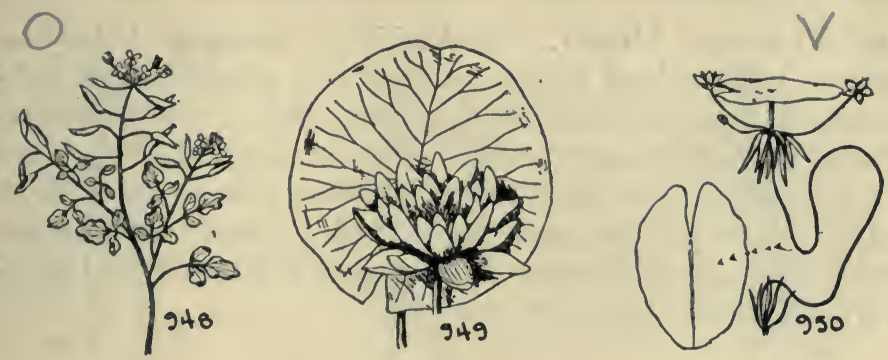

smooth aquatic, the stem spongy, submerged and about $\mathrm{I} I / 2$ ft. long. Leaves all submerged, divided nearly to the middle into narrow linear segments $1 / 2-2$ in. long. Flowers white, about $1 / 4$ in. long, arranged in small interrupted clusters of 2-8 flowers on stalks that are jointed and slightly constricted at the joints. In still, shallow water. New Hampshire and Mass. to central New York, south to Florida. July. Fig. 947. See No. 466.

948. Water-Cress. Sisymbrium Nasturtium-aquaticum. (Radicula Nasturtium-aquaticum.) (Crucifcrac.) A rampant aquatic producing a tangled mass of foliage at or just beneath the surface. Leaves of $3-9$ segments, the terminal one larger than those at the side, all more or less oval, or the end one nearly round. Flowers above the surface, white, about $1 / 4$ in. wide, in a small cluster. Petals 4 . Pod slender, $1 / 2-1 \frac{1}{2}$ in. long. In brooks or streams. Nova Scotia to Virginia and westward. Native of Europe. May-October. Fig. 948. See also Nos. 383 and 397.

949. Water Lily. Castalia odorata. (Nymphacaceae.) The most fragrant of all our aquatic plants. Leaves floating, very long stalked, the blades more or less oval or roundish, deeply cleft at the base, smooth above, more or less hairy and veiny beneath. Flowers white, rarely pinkish, solitary and floating at the end of long stalks. Petals numerous, merging insensibly towards the central organs of the flower, which may be $\dot{i}$ in. or even more across. Fruit ripening under water. In still water, Newfoundland to Florida, and westward. July. Fig. 949. 
950. Floating Heart. Nymphoides lacunosum. (Menyanthaceae.) A curious aquatic with a few membraneous submerged leaves and a single floating one that is oval or roundish and purplish beneath. Attached to the same stalk that bears the floating leaf is a small cluster of white flowers all on short stalks arising at the same point, and a cluster of narrow, small tubes. In quiet water. Nova Scotia to Florida, and westward. July. Fig. 950. See No. 799.

951. Flowers yellow, or purple, or rose-pink.

Flowers purple or rose-pink .................. no. 958 Flowers yellow

Plant of the Daisy Family with yellow ray flowers, and threadlike submerged leaves ........... Water Marigold no. 952 Plants without ray flowers, not of the Daisy Family

Submerged leaves not finely dissected or thread-like

Flowers small, crowded in a club-like cluster ...........

Flowers large, solitary at the ends of long stalks

Leaves deeply cleft at the base .... Spatter-dock no. 954

Leaves nearly round, not cleft, the stalk attached to the middle of the leaf .... American Lotus no. 955

Submerged leaves finely divided; plant with minute bladders; flowers irregular, spurred

Flowers I-5, about $3 / 4$ in. long ...... Bladderwort no. 956

Flowers I or 2, about $3 / 8$ in. long .... Bladderwort no. 957

952. Water Marigold. Megalodonta Beckii. (Bidens Beckii.) (Compositae.) A showy aquatic with both submerged and emersed leaves. Submerged leaves finely dissected into threadlike'segments. Emersed leaves few, opposite or in 3's, oblong or lance-oblong, toothed or even deeply divided. Flowers yellow, in solitary or few heads, $\mathrm{I}-2$ in. wide, with usually 6-10 rays. In quiet waters. Quebec to New Jersey, and westward. August. Fig. 952. For close relatives see Nos. 900 and 901. 953. Golden Club. Orontium aquaticum. (Araceae.) A rather fleshy aquatic with thick toothless, more or less, oblong leaves that are $2 \frac{1}{2}-6$ in. long, and $3 / 4-2$ in. wide. Flowers small, yellow, without petals, but crowded on a densely flowered club-like stalk that comes above the surface. In 

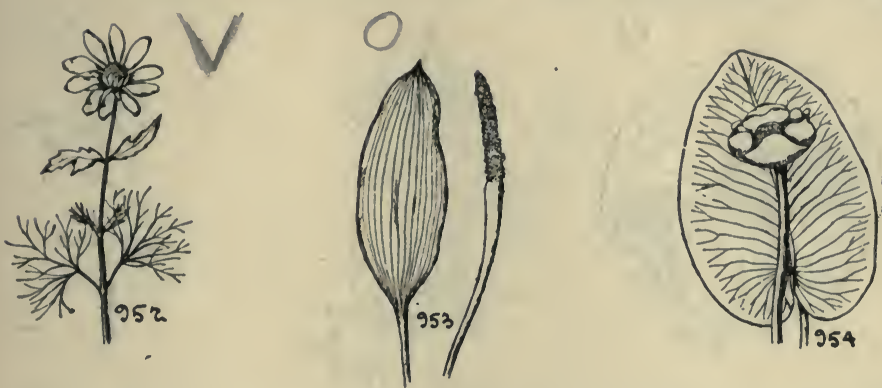

ponds, sometimes also in swamps, Mass. to Florida, mostly along the coast. April. Fig. 953. See No. 26.

954. SpatTER-DOck. Nymphaea advena. (Nymphaeaccae.) A coarse yellow water lily with submerged, floating and emersed leaves. Floating and emersed leaves long and stout-stalked, nearly round or round oval, 4-6 in. or even more long, deeply cleft at the base. Flowers yellow, almost always above the surface, sometimes on it, about $I \frac{1}{2}$ in. wide, the sepals petallike and incurved. Petals none. In quiet waters, nearly throughout North America. May-August. Fig. 954. There are several closely related species.

955. American Lotus. Nelumbo lutea. (Nelumbonaceae.) A stout aquatic with large, nearly round leaves that stand well above the water on stout. stalks attached to the middle of the leaf blade. Leaves prominently veined, $12-15$ in. in diameter. Flowers large, 3-5 in. across, pale yellow, the petals insensibly merging into the central organs of the flower. Fruits round, but more or less flat-topped, deeply pitted, the pits containing the nearly round seeds. In ponds and lakes. Ontario to Florida, and westward, but local in distribution and while common where found, only known from comparatively isolated'stations. July. Fig. 955.

956. BladDERWORT. Utricularia intermedia. (Lentibulariaccae.) A slender aquatic with finely dissected submerged leaves, the segments about $1 / 2$ in. long and thread-like. Among the leaves, or on the stem are minute but obvious bladders. Stems and leaves usually make an inextricable mass just beneath the surface, and from this rise above the surface slen- 

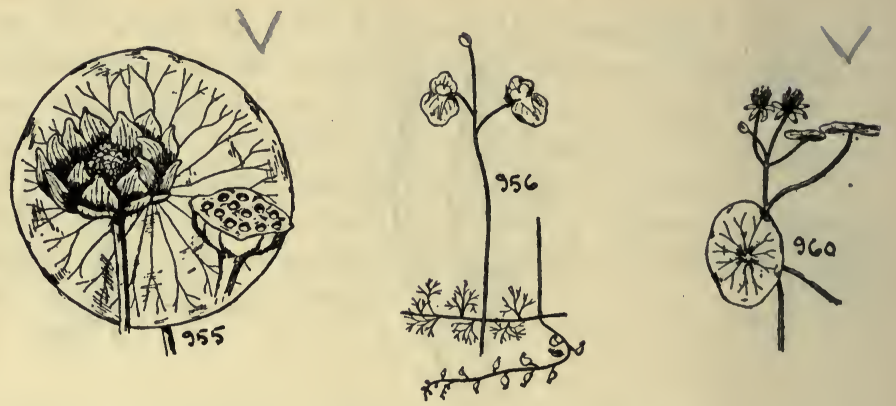

der scaly stalks crowned by $\mathrm{I}-5$ yellow, irregular and spurred flowers, that are about $3 / 4$ in. long. In shallow still water. New Brunswick to New Jersey. July. Fig. 956. Besides Nos. 957 and 959 there are several closely related species. See also No. 803 and 804.

957. Bladderwort. Utricularia gibba. (Lentibulariaceae.) Resembling No. 956 in general aspect and habit, but the flowers usually only I or 2 , and not over $1 / 2$ in. long. In shallow still water. Ontario and Maine to Alabama and westward. August. See also No. 803, 804, 956 and 959.

958. Flowers purple or rose-pink.

Flowers irregular and spurred; submerged leaves finely dissected ................... Purple Bladderwort no. 959

Flowers not irregular or spurred

Flower solitary; leaf stalk attached to center of leaf blade Water-shield no. 960 Flowers small, crowded in a finger-shaped cluster ........... ............................. Water Persicaria no. 961 959. Purple Bladderwort. Vesiculina purpurea. (Utricularia purpurea.) (Lentibulariaceae.) Resembling No. 956, but the submerged leaves in clusters of 4's or 5's, the segments thread like, and the flowers violet or reddish-purple. In ponds, Maine to Florida, and in Indiana. July. See No. 956. 960. Water-Shield. Brasenia Schreberi. (Cabombaceae.) A slender aquatic covered with a gelatinous film. Leaves floating, oval, toothless, $2 \frac{1}{2}-4$ in. long, the long stalk attached to 


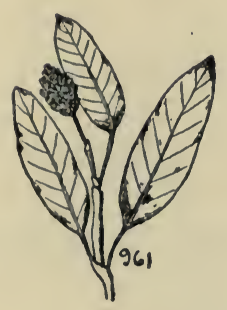

the middle of the blade. Flowers purplish, floating, long stalked, about $3 / 4$ in. wide. In still waters almost throughout North America. August. Fig. 960.

96r. Water Persicaria. Persicaria amphibia. (Polygonum amphibium.) (Polygonaccae.) A usually floating, rarely submerged aquatic with stalked, toothless, sometimes hairymargined, oblong, slightly inequilateral leaves, $2-5$ in. long. Near the base of the leaf-stalk the stem has a bristly sheath. Flowers small, pink, or rose-pink, crowded in a finger-shaped cluster. In ponds or lakes. Quebec to Kentucky, and westward. July. Fig. 96r. See No. 294. 



\section{INDEX}

The numbers refer to species numbers, not to pages.

Abama americana

Abutilon Abutilon Theophrasti

Achillea Millefolium

Acrida cannabina

Acorus Calamus

Actaea alba rubra

Adam-and-Eve Adam's Needle Adder's-mouth Adder's-tongue Adlumia fungosa

Agalinis maritima parvifolia paupercula purpurea tenuifolia

Agastache nepetoides

Agrimonia striata

Agrimony

Agrostemma Githago

Ajuga reptans

Aletris farinosa

Alfalfa

Alisma

Plantago-aquatica subcordatum

Alliaria

122

330

330

850

254

29

338

338

138

126

172

74,75

236

685

687

685

684

680

742

369

369

424

747

II 8

599

IO Alliaria officinalis

Allium canadense cernuum stellatum tricoccum vineale

Alpine Bistort Cinquefoil Alsike Clover

Alsine graminea longifolia media

Althaea

officinalis

Alum-root

Amaranth

Green

Amaranthus

$$
\text { graecizans }
$$

hybridus retroflexus

Ambrosia elatior trifida

American Brooklime Lotus Orpine Pennyroyal Senna Wild Mint

Amianthium muscaetoxicum Amphicarpa monoica

Anagallis arvensis

Anaphalis

Io margaritacea 
Anemone quinquefolia

Rue

Tall

virginiana

Anemonella

thalictroides

Angelica

atropurpurea

Great

Antennaria neodioica

Parlinii

plantaginifolia

Anthemis

Cotula

tinctoria

Anticlea

elegans

Anychia canadensis polygonoides

Apargia autumnalis

Apios

tuberosa

Aplectrum

hyemale

Apocynum androsaemifolium cannabinum

Apple

Mock

Aquilegia

canadensis

vulgaris

Arabidopsis

Thaliana

Arabis

hirsuta

laevigata

lyrata

Aralia

hispida

nudicaulis

racemosa

Arbutus, Trailing

Arctium

Lappa

minus

Arenaria

caroliniana
INDEX

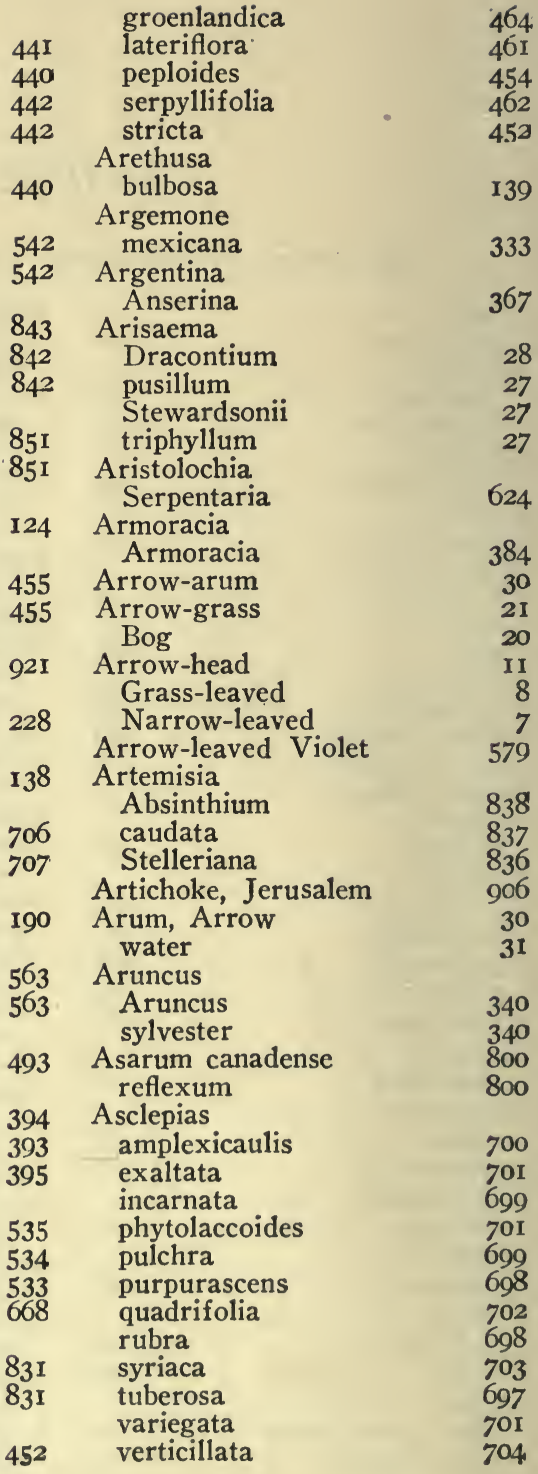


Asparagus officinalis

Asphodel

$$
\text { Bog }
$$

False

\section{Aster}

acuminatus

Blue Wood

concinnus

concolor

cordifolius

divaricatus

ericoides

Flat-top

Golden

laevis

Large-leaved

linariifolius

macrophyllus

Mountain

New England

New York

novae-Angliae

novi-Belgii

paniculatus

patens

Salt Marsh

Showy

Silvery

Smooth

spectabilis

Stiff

subulatus

Tall White

tenuifolius

umbellatus

undulatus

White Heath

White-topped

White Wood

Atamosco

Atamasco

Lily

Atragene

americana

Atriplex

arenaria

hastata

rosea

Sea-beach

Avens

Purple

Yellow
99 Yellow Mountain

360

122

121

Bachelor's-button

Balm

855 . Horse

860 Balsam

867

870

860

854

863

864

897,898

867

862

862

855

866

868

866

868

858

861

865

871

870

867

871

869

865

858

865

864

861

863

856

854

III

II I

24I

251

256

256

$25 \mathrm{I}$

342

347

368

\section{Groundsel}

Sweet

Baneberry

Baptisia

tinctoria

Barbarea

Barbarea 403

stricta

vulgaris

Barren Strawberry

Bartonia paniculata virginica

Basil

Field

Wild

Bastard Toad-flax

Batrachium

tricophyllum

Beach

Pea

Wormwood

Bean Vine

Beard-tongue

Bedstraw

Lady's

Bee Balm

Beech-drops

Beggar-ticks

Belamcanda

chinensis

Bellflower

European

Marsh

Tall

Bellwort

Bergamot, Wild

Bicuculla

832

774

741

894

846

338

597

403

403

365

805

805

746

757

648

946

220

8.36

230

795, 796, 797

735,737

733

774

808

615,900

II 4

662

660

663

$87,88,89$

775

558

558

558

Bidens

Beckii

952

901

900 
Bindweed

Corn

: Hedge

Low

Small

Trailing

Rird's-foot Violet

Bishop's-cap

Bishop's-weed Mock

Bistort

Alpine

Bistorta vivipara

Bitter-bloom

Bitter-cress

Meadow

Bitter Milkwort

Bitter-sweet

Bitter Weed

Blackberry Lily

Black-eyed Susan

Black Mustard

Nightshade

Snakeroot

Bladderwort • 803, 804, 956, 957 Purple

Blazing Star

Blephariglottis

Blephariglottis

ciliaris

cristata

grandiflora

lacera

leucophaea

peramoena

psycodes

Blephilia

ciliata

Blitum

capitatum

Bloodroot

Blooming Spurge

Blue-bell

Blue Cohosh

Curls

Lettuce

Plantain

Toad-flax

Vervain

Violet, common

Violet, early

Violet, marsh

167

I $7 \mathrm{I}$

I7 1

286

344

916

723
Violet, wooly

Wood Aster

576

860

2 IO

212

213

2 I I

$57 \mathrm{I}$

510

543

Blue-eyed Grass 46, 47, 48, 49,

Blue-flag

Blue-weed

$40,4 \mathrm{I}$

Bluets

Boehmeria cylindrica

Bog Arrow-grass

Asphodel

Orchis

247 Boneset

247 Bouncing Bet

4I6 Bracted Plantain

39I Bradburyå

390 virginiana

586 Brasenia

203 Schreberi

$88 \mathrm{I}$

II 4

890

$40 \mathrm{r}$

654

544

959

I I9, 828

I 68

166

170

169

170

Brassica

alba

nigra

Brauneria purpurea

Brooklime

American

Brook Lobelia

Buckbean

Buckwheat

False

Bugle

Weed

Bugloss

Viper's

Bulbous Buttercup

Cress

Bunch-berry

Bunch-flower

Burdock

754 Bur-head

Bur Marigold

625

694

266

20

122

147

812

460

276

233

960

398

401

853

790

633

799

301

205

747

718

625

355

392

448

128

831

9

500 Bur-reed

447 Bursa

666

762

35

569

577

$58 \mathrm{a}$

578
Burnet

Bursa-pastoris

Burseed

Bush-clover

Trailing

Bushy Golden Rod

901

307

$16,17,18$

Butter-and-Eggs

Buttercup

Bulbous

Creeping

Hairy
495

$64 \mathrm{I}$

619, 620

618

874

568

355

353

358 
Marsh

Meadow

Rough

Butterfly Pea

Butterfly-weed

Button Snakeroot

Cabbage Skunk

Cabomba caroliniana

Cakile edentula

Calamus Root

Calla palustris

Callitriche palustris

Calopogon pulchellus

Caltha palustris

Camassia esculenta

Camelina sativa

Campanula americana aparinoides rapunculoides rotundifolia

Campion White

Canada Golden Rod Hawkweed Thistle Violet

Canadian St. John's-wort Cancer-root

Candles Swamp

Cane-fly Orchis

Cannabis sativa

Capnoides auretum sempervirens

Capsella Bursa-pastoris

Cardamine bulbosa pennsylvanica pratensis
356

354

357

232

697

827

32

929

378

29

31

9.35

146

146

329

37

406

663

660

662

661

450

456

882

प25

824

582

479

807

469

I37

305

559

560

495

392

391

390
Cardinal-flower

Carolina Crane's-bill Vetch Water-shield

Carpet-weed

Carrion-flower

Carrot, Wild

Cassia

Chamaecrista marilandica

Castalia odorata

Castilleja coccinea

Catbrier

Catchfly Sleepy

Cathartolinum virginianum

Catnip

Cat's-foot

Cat-tail

Caulophyllum thalictroides

Celandine

Centaurea Cyanus nigra

Centrosema virginianum

Cerastium arvense vulgatum

Ceratophyllum demersum

Chamaecrista fasciculata nictitans

Chamaelirium luteum

Chamaenerion angustifolium

Chamaesyce maculata polygonifolia Preslii Charlock Cheeses

Chelidonium majus

Chelone glabra Chenopodium album ambrosioides Botrys 
$3^{20}$

capitatum

glaucum

hybridum

murale

Cherry

Ground

Chickweed

Forked

Chicory

Chimaphila

maculata

umbellata

Chiogenes

hispidula

Chrosperma muscaetoxicum

Chrysanthemum Leucanthemum

Chrysopsis falcata mariana

Chrysosplenium americanum

Cicely Sweet

Cichorium Intybus

Cicuta maculata

Cimicifuga racemosa

Cinquefoil

Alpine

Purple

Silvery

Tall

Three-toothed

Circaea

alpina

lutetiana

Cirsium

altissimum

arvense

discolor

horridulum

lanceolatum spinosissimum

Claytonia

caroliniana

virginica

Clearweed
INDEX

286 Cleavers

284 Cross

283 Clematis

283 crispa

Curl-flowered

734

652

457,459

455

909

444

444

669

123

849

897

898

258

545

909

$54 \mathrm{I}$

339

364,366

362

345

361

$34 \mathrm{I}$

504

445

445

822

824

823

823

821

823

315

315

265
Mountain

ochroleuca

verticillaris

viorna

virginiana

Climbing Fumitory

Hempweed

Nightshade

Clinopodium

vulgare

Clintonia

borealis

umbellulata

White

Clitoria

mariana

Closed Gentian

Clot-bur

Clover

Alsike

Bush

Old-field

Red

White

Yellow

Coast Joint-weed

Coeloglossum bracteatum

Cohosh

Blue

Colic Root

Collinsonia

canadensis

Coltsfoot

Sweet

Columbine

Comandra

livida

pallida

umbellata

Comarum

palustre

Comfrey

Wild

Commelina

communis

nudiflora
240

240

241

430

$24 \mathrm{I}$

239

238

236

109

203

746

77,78

78

79

79

232

673

834

607

619, 620

605

606

604

603

295

I 78

344

I 18

$74 \mathrm{I}$

886

848

563

648

648

648

345

637

639

52

52 
virginica

Common Blue Violet

Dock

Hoarhound

Milkweed

Mint

Plantain

Pondweed

St. John's-wort

Speedwell

Sunflower

Thistle

White Daisy

Wormwood

Cone-flower

Purple

Tall

Conium maculatum

Conopholis americana

Convallaria majalis

Convolvulus arvensis

repens

sepium

spithamaeus

Coptis

trifolia

Corallorrhiza maculata

Coral-root

Coreopsis

lanceolata

rosea

Corn Bindweed

Cockle

Flower

Gromwell

Cornus canadensis

Corydalis

aurea

Golden

Pink

sempervirens

Cow-parsnip

Cowslip

Virginia

Cow Vetch

Cow-wheat
53 Cracca

577 virginiana

302 Crane's-bill

766 Carolina

703 Wild

714 Creeping Buttercup

274 St. John's-wort

93a Snowberry

475 Cress

79I Bitter

903 Bulbous

821 Field

840 Hairy Rock

Meadow Bitter

Mouse-ear

853 Rock

889

548

806

76

213

2 I I

210

212

499

Smooth Rock

Water

Yellow Water

Crocanthemum

canadense

Cross Cleavers

Crosswort

Crotalaria

sagittalis

Crow foot

Kidney-leaved

Water

Crow-poison

Cryptotaenia canadensis

I36 Cuckoo Flower

I36 Cucumber-root

Cucumber

896 star

895 Culver's-root

205 Cunila

424

832

644

448

559

559

560

560

540

$$
\text { origanoides }
$$

Cuphea petiolata

Curl-flowered Clematis

Cuscuta

Gronovii

Cynanchum nigrum

Cynoglossum

officinale

virginianum

595

427

426

353

474

669

391

392

385

390

493

395

393

948

397

334

734

467

593

352

946

123

546

422

92

I9I

731

745

4 I I

240

242

200

638

639

912

912

636

224

783

Cynthia virginica

530

Cypress Spurge

Cypripedium

acaule 
arietinum

candidum

hirsutum

parviflorum

reginae

Daffodil

Daisy

Common White

Fleabane

Dalibarda repens

Dandelion

Fall

Dasystephana

Andrewsii

linearis

Porphyrio

Saponaria

Dasystoma

flava

pedicularia

virginica

Datura

Stramonium

Daucus

Carota

Day-flower

Day Lily

Decodon verticillatus

Delphinium

Ajacis

exaltatum

Dentaria diphylla

laciniata

Deptford Pink

Deringa canadensis

Desmodium

Dewdrop

Dianthus

Armeria deltoides

Diapensia lapponica

Dicentra canadensis Cucullaria eximia

Dichrophyllum marginatum

52,53

35 , II 5

412

564

564

389

389

421

546

6 Io

519

421

423

728

728

558 Early Blue Violet

558 Golden Rod

5.58

528

Dracocephalum virginianum

Dragon-head

Dragon's-mouth

Drooping Ladies'tresses

Drosera

filiformis

rotundifolia

Drymocallis agrimonioides

Duchesnea indica

Duckweed

Dusty-clover

Dwarf Ginseng

Iris

St. John's-wort
Dillweed

Dioscorea villosa

Disporum

Dock

Common

Great Water

Spatter

Swamp

Dodder

Dodecatheon Meadia

Doellingeria humilis

umbellata

Dogbane

Dog Plum

Dog's-tooth Violet White

Dondia

linearis

maritima

Downy Skullcap

Draba

caroliniana

verna

Dutchman's Breeches

132

90

302

262

954

263

242

527

864

864

706

79

73,74

75

255

255

780

494

494

750

750

I39

I 49

$49 I$

490

34I

363

927

621

558

536

43

478

580

880

310

512 
purpurea

Echinocystis lobata

Echinodorus cordifolius radicans

Echium vulgare

Eel-grass

Elder

Marsh

Wild

Elecampane

Elodea canadensis

Enchanter's Nightshade

Epifagus virginiana

Epigaea repens

Epilobium adenocaulon angustifolium coloratum hirsutum lineare palustre strictum

Epipactis

Erechtites hieracifolia

Erigeron annuus canadensis philadelphicus pulchellus ramosus

Eriocaulon decangulare septangulare

Erysimum officinale

Erythronium albidum americanum

Eupatorium album

hyssopifolium maculatum perfoliatum purpureum
853 sessilifolium

814

$8 \mathrm{II}$

$8 \mathrm{I} 4$

190 verbenaefolium

Euphorbia

9 corollata

9 Cyparissias

625 Ipecacuanhae

934

$8 \mathrm{I} 6$

535

902

937

445

808

668

436

379

436

435

438

437

438

I 52

840

857

$84 \mathrm{I}$

859

859

857

14

I3

400

75

74

813

8 10

815

812

815 maculata marginata polygonifolia Dreslii

European Bellflower

Euthamia graminifolia tenuifolia

Evening Primrose

Everlasting Pea Pearly

Fagopyrum esculentum Fagopyrum

Falcata comosa Pitcheri

Fall Dandelion Meadow Rue

False Asphodel Buckwheat Foxglove Gromwell Heather

Lily-of-theValley Loosestrife Mermaid Nettle Onion

447

530

529

419

268

528

252

278

662

874

874

408

216

845

$30 I$

301

234

234

921

3I I

I2 I

205

710, 7II

646

48r, 482

85

380

382

266

106

763

785

83

888

256

947

829

935

746 
Thistle

Figwort

Filipendula

rubra

Ulmaria

Fireweed

Flag, Sweet

Flat-top Aster

Flax

Yellow

Fleabane

Daisy

Salt Marsh

Small

Floating Heart

Floerkea proserpinacoides

Flowering Rush

Yellow

Fly-poison

Foam-flower

Forget-me-not

Forked Chickweed

Foxglove, False

Fragaria

americana

virginiana

Fringed Gentian Loosestrife

Fringed Orchis

Purple

white

Yellow

Frostweed

Fumaria officinalis

Fumitory, Climbing Hedge

Galactia

regularis

volubilis

Galeopsis Tetrahit

Galeorchis spectabilis

Galinsoga parviflora

Galium

Aparine asprellum boreale
822 circaezans

788 Claytoni

346

346

379

29

864

319

335

857

857

826

861

950

382

22

23

123

497

642

455

710,711

503

503

672

470

170

168

167

334

$56 \mathrm{I}$

236

561

231
231
769
157
817
736
737
735

lanceolatum verum

Garden Phlox Valerian

Garlic, Hedge Meadow Wild

Gaultheria procumbens

Gay Feather Wings

Gemmingia chinensis

Gentian Fringed Horse One-flowered Stiff

Gentiana

Andrewsii crinita linearis

Porphyrio procera quinquefolia

Geranium carolinianum maculatum Robertianum

Gerardia flava pedicularia Purple Salt Marsh virginica

German Iris

Geum

$23 \mathrm{I}$

231

769

157

817

736

Gillenia trifoliata

Ginger, Wild

Ginseng

Dwarf

Glasswort
734

737

734

733

680

721

388

109

108

726

829

59I

II 4

675

672

678

674

676

673

672

675

674

672

676

\section{7}

426

428

686, 687

7 II

710

684

685

7 II

42

342

360

347

368

742

473

907

337

800

537

536 


\section{INDEX}

Glechoma hederacea

Globe-flower

Glycine Apios

Gnaphalium obtusifolium polycephalum uliginosum

Goat's-beard

Golden Aster Club

Corydalis

Ragwort

Goldenpert

Golden Rod Bushy

Canada

Early

Gray

Hairy

Large-leaved

Ragged

Seaside

Silver

Sweet-scented

Golden Seal

Gold of Pleasure

Gold-thread

Gonolobus

laevis

Goosefoot

Goose-grass

Gourds

Grape Hyacinth

Grass

Blue-eyed

Yellow-eyed

Grass-leaved Ladies'tresses

Grass-of-Parnassus

Grass-pink

Gratiola

aurea

virginiana

Gray Golden Rod

Great Angelica

Lobelia

Mullein
Spurred Violet

Water Dock

350 Willow-herb

Green Amaranth

228 Dragon

Orchis

846 Gromwell

846 Corn

844 False

340

897,898 ,

953

559

893

784

874

882

880

883

877

878

884

875

876

879

306

406

499

Ground-cherry

Ground Ivy

Nut

Pink

Groundsel, Balsam

Gymnadeniopsis clavellata

integra

nivea

Gyrotheca

tinctoria

575

262

435

289

28

I79

644

646

652

767

228

727

894

182

182

I8I

102

Habenaria

bracteata

flava

obtusata

orbiculata

Hairy Buttercup

Golden Rod

Hawkweed

Harebell

200 Hasheesh

283,284 , Hawkweed

Canada

Hairy

Orange

I65, 180,183

178

179

147

158

358

877

924

661

305

925

924

923

773

481,482

Heather, False

Hedeoma pulegioides

Bindweed

744

210

$56 \mathrm{I}$

388

400

752

$75 \mathrm{I}$

753

784 Helenium

784 autumnale

883 Helianthemum

542

630

656 canadense

Helianthus annuus

891 
decapetalus

divaricatus

giganteus

tuberosus

Heliopsis

helianthoides

scabra

Hellebore

Helonias

bullata

Hemerocallis fulva

Hemlock

Poison

Water

Hemp

Water-parsnip

Indian

Hemp-nettle, Red

Hempweed

Climbing

Henbit

Hepatica

Hepatica

triloba

Heracleum

lanatum

Herb Robert

Heuchera americana

Hibiscus

militaris

Moscheutos

Trionum

Hieracium

aurantiacum

canadense

Gronovii

praealtum

venosum

High Mallow

Hipposelinum Levisticum

Hoarhound

Common

Water

Hoary Puccoon

Honewort

Honeysuckle

Italian

Japanese

Trumpet
INDEX

905 Honkenya

904 peploides

907 Hop

906 Hornwort

Horse Balm

Gentian

Mint

Mint, Ohio

Nettle

II7 Horseradish

II5 Hottonia inflata

548 Hound's-tongue

54I Houstonia

550 ciliolata

305 coerulea

707 longifolia

769 Hudsonia

199

770

498

498

498

540

428

509

323

323

324

923

925

924

923

922

327

553

766

719, 720

$6+5$

546

ericoides

tomentosa

Humulus

Lupulus

Hyacinth, Grape

Wild

Hydrastis

canadensis

Hydrocotyle

americana

umbellata

Hydrophyllum

canadense

virginianum

Hypericum

adpressum

454

198

938

741

678

715

754

653

384

947

638

694

693

694

$48 \mathrm{r}$

482

198

34

37

306

539

539

665

665

474

473

479

479

477

483

478

475

476

$4 \mathrm{I} 3$

virginicum

Hypopitys

americana

lanuginosa

486

Hypoxis

hirsuta

486

IOI

193 Hyssop 759

196 Giant 742

196 Hedge Nettle 751 
Skullcap

Hyssopus

cfficinalis

Ibidium

cernuum

gracile

praecox

Illysanthes

dubia

Ill-scented Wake-robin

Impatiens

biflora

pallida

Indian Hemp

Indian Mallow

Physic

Pipe

Poke

Tobacco

Indigo, Wild

Inula

Helenium

Ionactis

linariifolius

Ionoxalis violacea

Ipecac, Wild

Ipomoea

hederacea

pandurata

Iris purpurea

cristata

Dwarf

German

germanica

prismatica

pseudacorus

Spring

verna

versicolor

Ironweed

Isanthus

brachiatus

Isotria

verticillata

Italian Honeysuckle

Iva

frutescens

oraria
779 Ivy, Ground

767

759

149

I5I

150

785

69

566

567

707

330

337

487

$8 \mathrm{I}$

632

597

902

869

505

419

208

207

208

43

43

42

42

$4 \mathrm{I}$

39

44

44

40

830

763

164

193

$8 \mathrm{I} 6$

816

Jack-in-the-Pulpit

Japanese Knotweed Honeysuckle

Jeffersonia diphylla

Jerusalem Artichoke

Jimson-weed

Joe-Pye Weed

Joint-weed

Coast

27

299

I96

501

906

651

815

295

Kidney-leaved Crow-

$$
\text { foot }
$$

Knapweed

Kneiffia

fruticosa

Knot-grass

Knotweed

Japanese

Virginia

Koellia

flexuosa

incana

mutica

virginiana

Krigia

amplexicaulis

352

832

409

270

296

299

303

$75^{8}$

757

757

758

913

912

913

Lachnanthes tinctoria

Lacinaria

scariosa

spicata

squarrosa

Lactuca

canadensis

hirsuta

spicata

Ladies'-slipper

Pink

Ram's Head

102

827

829

828

917

918

916

I4I

144

I 43

I 45

142

White

Yellow

Ladies'-tresses

Drooping

149

Grass-leaved

150

I 5 I 


\section{8}

Lady's Bedstraw Thumb

Lamium

album

amplexicaule

Laportea canadensis

Lappula echinata Lappula virginiana

Large-leaved Aster Golden Rod Pondweed

Larkspur Rocket

Lathyrus latifolius maritimus myrtifolius ochroleucus palustris pratensis venosus

Lavender Sea

Leafy Pondweed

Leather Flower

Lechea intermedia maritima minor tenuifolia

Lemna trisulca

Leek, Wild

Lenntodon autumnalis Taraxacum

Leonurus cardiaca

Lepidium campestre virginicum

Leptamnium virginianum

Leptandra virginica

Leptilon canadense

\section{INDEX}

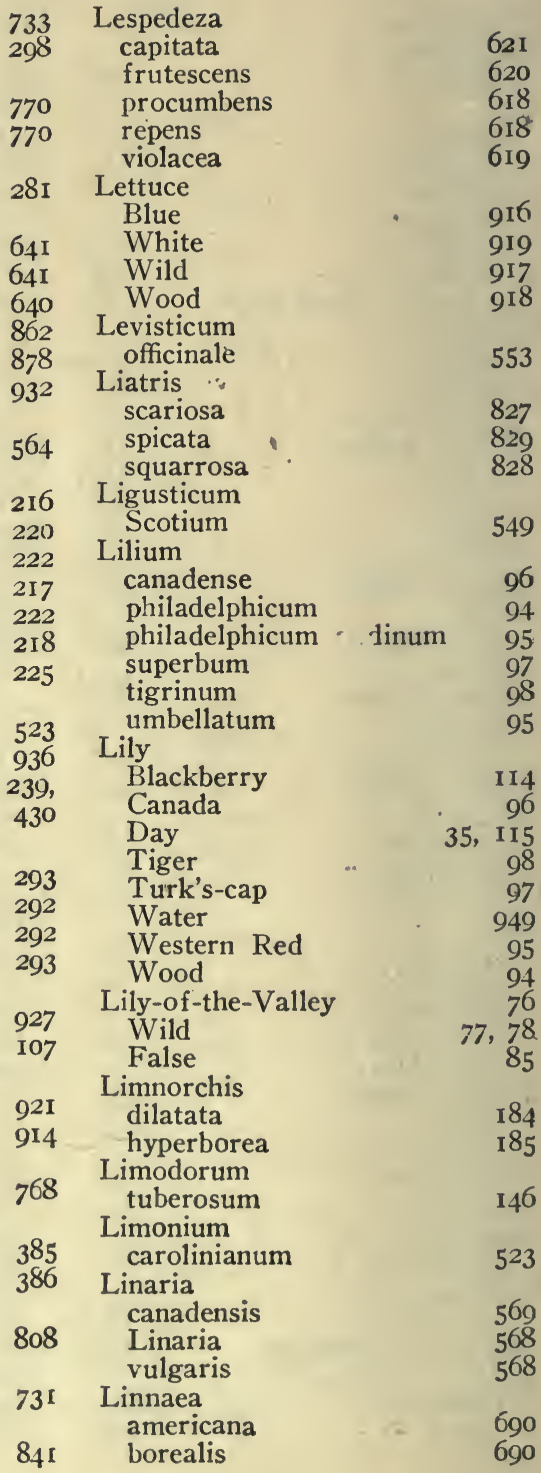


Linum

usitatissimum

virginianum

Liparis

liliifolia

Loeselii

Listera

Lithospermum

arvense

canescens

officinale

Lizard's-tail

Lobelia

Brook

cardinalis

Dortmanna

Great

Kalmii

inflata

Pale

puberula

spicata

syphiliticam

Water

Lonicera

caprifolium

dioica

glaucescens

hirsuta

japonica

sempervirens

Sullivantii

Loosestrife

False

Fringed

Purple

Swamp

Tufted

Lophiola

americana

aurea

Lopseed

Lotus

American

Lousewort

Lovage

Sea

Low Bindweed

Sea-blite

Ludwigia

alternifol:

sphaerocarpa
319

335

160

I6I

173

644

645

644

259

633

629

945

$63 a$

633

632

631

630

631

630

945

193

195

I94

194

196

I96

195

380

470

414

412

$47 \mathrm{I}$

103

103

739

955

627

553

549

212

255

407

380
Lupine

Lupinus

perennis

Lychnis alba

Flos-cuculi

Lycopus americana

europaeus

virginicus

Lysias

Hookeriana orbiculata

Lysiella obtusata

Lysimachia Nummularia quadrifolia terrestris

Lythrum

Salicaria

Mad-dog Skullcap

Maianthemum canadense

Malaxis

monophylla

unifolia

Mallow

High

Indian

Marsh

Musk

Rose

Malva

moschata

rotundifolia

sylvestris

Marigold

Bur

Marsh

Water

Marjoram, Wild

Marrubium

vulgare

Marsh Bellflower

Blue Violet

Buttercup

Elder

Mallow

594

594

456

422

719

720

718

I 58

158

147

468

467

469

414

777

85

172

172

327

330

322

326

323

326

325

327

90I

329

952

764

766

660

578

356

816

322

329

587 
Pink

St. John's-wort

Skullcap

Willow-herb

May Apple

Mayflower

Moneywort

Monkey-flower

Meadow Beauty

Bitter-cress

Buttercup

Garlic

Parsnip

Pea

Pink

Meadow Rue

Early

Fall

Medeola virginiana

Medic

Medicago

lupulina

sativa

Megalodonta

Beckii

Meibomia

canadensis

Dillenii

grandiflora

Michauxii

nudiflora

paniculata

Melampyrum

lineare

Melanthium

latifolium

virginicum

Melilot

Melilotus

alba

officinalis

Mentha

aquatica

arvensis

canadensis

longifolia

piperita

spicata

Menyanthes

trifoliata

Mermaid, False

\section{INDEX}

418

413

778

437

508

668

468

782

432, 433

390

354

I09

555

218

423

309

310

3I I

92

600

600

599

952

6 II

613

615

616

614

612

783

128

128

601

601

6oI

715

716

716

715

7 I 4

714

799
Mermaid-weed

Mertensia

virginica

Mexican Tea

Micrampelis

lobata

Micranthes

pennsylvanica virginiensis

Microstylis unifolia

Mikania

scandens

Mild Water-pepper

Milfoil

Water

Milk Pea

Purslane

Milkweed

Common

Poke

Purple

Running

Swamp

Whorled

Milkwort

Bitter

Marsh

Orange

Purple

Whorled

Mimulus

ringens

Mint

\section{American Wild}

Common

Horse

Mountain

Ohio Horse

Stone

Mitchella

repens

Mitella

diphylla

nuda

Moccasin Flower

Mock Apple

Bishop-weed

Strawberry

Modesty

Moehringia lateriflora
928

636

285

190

522

512

I72

I99

260

939

231

268

700, 702

703

701

698

201

699

704

586

587

585

589

588

782

716

714

715

758

754

745

689

510

510

I4I

190

543

363

324

$46 \mathrm{I}$ 
Mollugo verticillata

Monarda didyma fistulosa mollis

Moneses uniflora

Moneywort

Monkey-flower

Monotropa Hypopitys uniflora

Morning-glory

Motherwort

Moth Mullein

Mountain Aster Avens, Yellow Clematis

Mint Sorrel

Mouse-ear Cress

Mullein

Great

Moth

Muscari botryoides racemosum

Musk Mallow

Mustard

Black

Hedge

White

Myosotis

laxa

scorpioides virginica

Myriophyllum pinnatum scabratum

Nabalus altissimus trifoliolatus

Narcissus Pseudo-Narcissus

Narthecium americanum

Naumburgia thyrsiflora
Nelumbo lutea

Nepeta

Cataria hederacea

Nettle

False

518

468

782

485

487

208

768

657

855

360

241

758

246

844

493

656

657

34

34

326

401

400

398

642

642

643

939

939

Hedge

Horse

Hyssop Hedge Rough Hedge

Stinging

Wood

New England Aster

New York Aster

Nightshade

Black

Climbing

Enchanter's

Niobe coerulea

Nodding Pogonia

Wake-robin

Norta

altissima

Nothoscordum bivalve

Nymphaea advena

Nymphoides

lacunosum

955

776

767

266

752

653

$75 \mathrm{I}$

753

279

28I

866

868

654

203

445

35

177

70

402

106

954

950

89

sessilifolia

Oceanorus

leimanthoides

127

Oenothera

biennis fruticosa

Ohio Horse Mint

Old-field Clover

One-flowered Gentian Wintergreen

Onion

False

Prairie

Wild

408

409

754

605

674

518

107

106

IIO

110

II3 Onosmodium virginianum

646

122

Ophrys australis

175

471

cordata 
convallarioides

Opuntia

Opuntia vulgaris

Orange-grass

Orange Hawkweed Milkwort

Orchis

Bog

Bracted Green

Cane-fly

Green

Large

Northern Green

Northern White

Purple

Purple-fringed

Ragged

rotundifolia

Showy

Small

Small Green Wood spectabilis

White-fringed

Yellow crested

Yellow-fringed

Origanum

vulgare

Ornithogalum umbellatum

Orobanche uniflora

Orontium aquaticum

Osmorhiza Claytoni

Oswego Tea

Oxalis Acetosella violacea

Oxyria digyna

Oyster Plant

Painted-cup

Painted wake-robin

Pale Lobelia

St. John's-wort

Touch-me-not

Vetchling

Panax

quinquefolium
I76 trifolium

Parnassia

484 caroliniana

484 Parsley-piert

483 Parsnip

923 Meadow

585 Parsonsia petiolata

147 Partridge-berry

I78 Passiflora

I37 incarnata

I79' lutea

158

185

184

169

170

I7I

156

157

156

182

157

I68

166

- 168

764

Passion-flower

Passion-vine

Pastinaca

Pea

sativa

Beach

Butterfly

Everlasting

Meadow

Milk

Sensitive

Spurred Butterfly

Veiny

Wild

Peanut, Wild

Pear, Prickly

Pearlwort

I04 Pearly Everlasting

Pedicularis

807

953

545

774

$37 \mathrm{I}$

506

505

246

910

626

71

631

477

567

217 canadensis lanceolata

Peltandra virginica

Pencil-flower

Penny-cress

Field

Pennyroyal

American

False

536

520

269

554

555

4 I I

689

I 88

I 88

I 88

I88

554

220

232

216

218

231

376

233

225

222

234

484

463

845

627

627

30

609

387

744

763

539

264

Penthorum sedoides

Pentstemon

Digitalis

797

795

797

795

796

386

389 
Pepper, Wall

Peramium ophioidies pubescens tesselatum

Persicaria amphibia hydropiperoides orientalis Persicaria Water

Perularia flava

Petasites palmatus

Phaseolus polystachyus

Philotria canadensis

Phlox divaricata Garden maculata paniculata pilosa Prairie subulata Wild Blue

Phryma Leptostachya

Physalis heterophylla peruviana virginiana

Physic Indian

Physostegia virginiana

Phytolacca americana decandra

Pickerel-weed

Pigweed

Pilea pumila

Pilewort

Pimpernel False Scarlet Water Yellow Pine-sap
332 Pink

Corydalis 560

421

146

I55 Grass

154 Ground

Marsh

727

418

423

417

Sea

260

297

298

961

Swamp

Wild

Pinweed

Pipewort

179 Pipsissewa

Pitcher Plant

848 Plantago

aristata

230

halophila lanceolata

937

682

680

680

680

$68 \mathrm{I}$

$68 \mathrm{I}$

727

682

739

652 major

Plantain Bracted Common Rattlesnake Water

I 53, I 54, I 55

Pleuropterus Zuccarinii

Pluchea camphorata

Plum, Dog

Podophyllum peltatum

Pogonia

652 divaricata

652 Nodding ophioglossoides

284

265

840

Rose trianthophora verticillata Whorled

Poison Hemlock

Poke Milkweed

Pokeweed

Polemonium

reptans

Van Bruntiae

299

826

Polygala cruciata

$785^{\circ} \quad$ lutea paucifolia polygama 


\section{INDEX}

viridescens

Polygonella

articulata

Polygonatum

biflorum commutatum

Polygonum amphibium aviculare convolvulus cuspidatum hydropiperoides maritimum orientale Periscaria sagittatum tenue virginianum viviparum

Pondweed Common Large-leaved Leafy

Pontederia cordata

Poppy, Prickly

Porteranthus trifoliatus

Portulaca oleracea

Potamogeton amplifolius epihydrus foliosus natans perfoliatus

Potato Vine, Wild

Potentilla Anserina argentea arguta canadensis monspeliensis palustris recta Robbinsiana tridentata

Poverty Grass

Prairie Onion Phlox

Prenanthes altissima

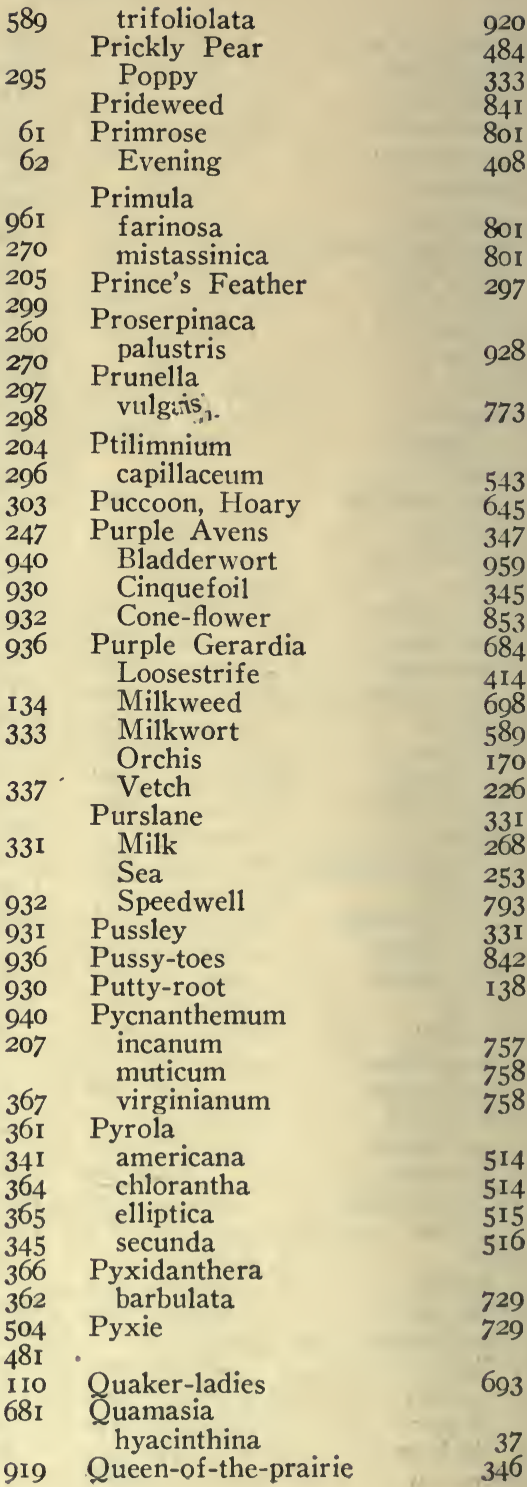


Radicula Armoracia hispida

Nasturitium-aquaticum palustris

Radish, Wild

Ragged Golden Rod Orchis Sailor

Ragweed

Ragwort, Golden

Ranunctulus abortivus acris aquatilis var. capillaceus bulbosus capillaceus hispidus laxicaulis obtusiusculus recurvatus repens septentrionalis

Raphanus Raphanistrum

Rattle Box

Rattlesnake Plantain 153, I54, I55 Root Weed

Red Clover Hemp-nettle Root

Rhexia aristosa mariana virginica

Rhinanthus Crista-galli

Ribwort

Robertiella Robertiana

Rock-cress Hairy Smooth

Rocket Larkspur Sea Yellow

Rose-mallow

Rose Pogonia Tickseed Rough Buttercup
Hedge Nettle

Woodbine

Rudbeckia

397

948

397

399

884

I 71

832

8 I8

893

352

354

946

355

946

358

$35 \mathrm{I}$

$35 \mathrm{I}$

357

353

356

399

787 407,593

920

922

606

769

I02

433

432

433

787

275

428

395

394

393

564

378

403

323

I63

895

357 hirta

laciniata

Rue

Anemone

Early Meadow

Fall Meadow

Meadow

Rumex

Acetosella

Britannica

crispus

verticillatus

Running Milkweed

Ruppia maritima

Sabbatia

angularis dodecandra

lanceolata

stellaris

Sage, Wild

Wood

Sagina

decumbens

procumbens

Sagittaria

graminea

latifolia

pubescens

subulata

St. John's-wort

Canadian

Common

Creeping

Dwarf

Giant

Marsh

Pale

Spotted

Salicornia europaea

Salsola

Kali

pestifer

Salt Marsh Aster

Fleabane

Gerardia

Water-hemp

Saltwort
753

194

890

889

440

310

3 I I

309

300

262

302

263

201

942

942

416

418

416

417

749

772

463

463

8 
Salvia

lyrata

Samolus

floribundus

Samphire

Sand Vine

Sandwort

Mountain

Seabeach

Sanguinaria canadensis

Sanguisorba canadensis

Sanicula marylandica

Saponaria officinalis

Sarothra gentianoides

Sarracenia purpurea

Sarsaparilla, Wild

Satureia hortensis vulgaris

Saururus cernuus

Savory

Saxifraga pennsylvanica virginiensis

Saxifrage, Early Swamp

Scarlet Pimpernel

Scheuchzeria palustris

Scleranthus annuus

Scorpion-grass Spring

Screw-stem

Scrophularia leporella marilandica

Scutellaria canescens galericulata incana integrifolia lateriflora

Seabeach Atriplex Sandwort

INDEX

Sea-blite

749

649

312

200

$452,461,462$

464

454

500

307

544

460

483

489

534

760

746

259

760

522

512

512

522

691

20

269

643

805

788

788

780

778

780

779

777

$25 \mathrm{I}$

454
Low

Sea Lavender

255

Lovage

Pink

Purslane

Rocket

Wrack

Seaside Golden Rod

Spurge

Sedum

acre

purpureum

telephioides

ternatum

triphyllum

Seneca Snakeroot

Senecio

aureus

Balsamitae

pauperculus

Senna, American

Sensitive Pea

Sericocarpus

asteroides

linifolius

Sesuvium

maritimum

Setiscapella subulata

Shepherd's-purse

Shin-leaf

Shooting Star

Showy Aster Tick-trefoil

Sibbaldiopsis

tridentata

Sicyos

angulatus

Sieversia

Peckii

Silene

alba

antirrhina

Armeria

caroliniana

stellata

Silver Rod

Weed

Silvery Aster

Cincuefoil
523

549

4 I7

253

378

943

875

252

332

318

$3 \mathrm{I} 8$

317

318

590

893

894

894

375

376

856

856

253

803

495

$514,515,516$

527

871

6 II

504

I9I

360

450

525

525

524

450

876

367

870

$36 \mathrm{I}$ 
Sinapis

alba

arvensis

Sisymbrium

altissimum

Nasturtium-aquaticum

officinale

Tall

Thalianum

Sisyrinchium

albidum

angustifolium

arenicola

atlanticum

gramineum

Sium

graminoides

cicutaefolium

Skevish

Skullcap

Downy

Hyssop

Mad-dog

Marsh

Skunk Cabbage

Sleepy Catchfly

Slender Ladies'-tresses Vetch

Small Bindweed

Fleabane

Woodbine

Smilacina

racemosa

stellata

Smilax

herbacea

Smooth Aster

Snake-mouth

Snakeroot

Black

Button

Seneca

Virginia

White

Sneezeweed

Snowberry, Creeping

Snow-on-the-mountain

Soapwort Gentian

Solanum

carolinense

Dulcamara

nigrum

Solidago

altissima $\quad 882$

arguta $\quad 880$

bicolor $\quad 876$

caesia $\quad 876$

948 graminifolia $\quad 874$

400 hispida 877

402 juncea 880

493 macrophylla 878

nemoralis 883

47 odora 879

48 rugosa 88I

49 sempervirens 875

50 squarrosa 884

50 ulmifolia 88I

50 Solomon's Seal

Star-flowered

550 Sonchus

859

780

779

777

778

32

525

I 5 I

22 I

213

86 I

I95

83

84

I3I

oleraceus

Sorrel, Field

9I I

Mountain

300

246

Tall

372

Wood

37 I

Yellow

373

Sow-thistle

9II

Sparganium

americanum var. androcladum androcladum

angustifolium

eurycarpum

I7

Spathyema

foetida

Spatter-dock

Spearwort, Water

Specularia

867 perfoliata

$89 \mathrm{r}$

669

528

673

Speedwell

\section{Common}

Purslane

Spergula

arvensis

793

Spiderwort

Spikenard

False

54,55

533

Spiranthes

Spotted St. John's-wort 476 Spurge

Touch-me-not

Wintergreen

653

203

654

Spring Beauty

Iris 
Scorpion-grass

Spurge, Blooming

Cypress

Seaside

Spotted

Sun

Spurry

Squaw-root

Squirrel-ear

Stachys

aspera

hyssopifolia

palustris

tenuifolia var. aspera

Stagger-grass

Star Cucumber

Blazing

Flower

Grass

Star-of-Bethlehem

Steironema

ciliatum

lanceolatum

Stellaria

graminea

longifolia

media

Stenanthium

robustum

Stick-tight

Stiff Aster

Gentian

Stinging Nettle

Stitchwort

Stomoisia cornuta

Stonecrop

Virginia

Wild

Stone Mint

Strawberry

Barren

Blite

Mock

Tomato

Wild

Streptopus

amplexifolius roseus

Strophostyles

helvola

umbellata
643 Stylosanthes

447 biflora

530 Suaeda

252 maritima

278 Sundew

529 Sundrops

45 I Sunflower

806 Common

I53 False

Giant

753

$75 \mathrm{I}$

752

753

I I I

I9I

828

449

I0I, II 8

I04

470

470

458

458

459

129

640

869

676

279

458

804

264

317

745

365

286

363

652

503

58

59

229

229

Wild

Woodland

Sun Spurge

Dock

Milkweed

Pink

Saxifrage

Cicely

Coltsfoot

Flag

Symphytum

officinale

foetidus

Syndesmon

Taenidia

Cinquefoil

Tanacetum

vulgare

Tansy

Taraxacum

officinale

Tar Weed

Oswego

Tear-thumb

Tephrosia

virginiana

Teucrium
Swamp Candles

Loosestrife

Sweet Balsam

Sweet-pea, Wild

Sweet-scented Golden Rod 879

Symplocarpus

thalictroides

integerrima

Tall Anemone

552

442

663

341

Cone-flower

889

402

858

Tea, Mexican
835

835

914

4 II

285

774

204

595 


canadense
littorale
Thalesia
uniflora
Thalictrum
dioicum
polygamum
revolutum
Thaspium
barbinode
Thistle
Canada
Common
Field
Sow
Yellow
Thlaspi

arvense

Thoroughwort Vervain White

Three-toothed

Thyme, Wild

Thymus Serpyllum

Tiarella cordifolia

Tickseed Rose

Tick-trefoil Showy Trailing

Tiger Lily

Tiniaria

Convolvulus

Tipularia discolor unifolia

Tithymalopsis corollata Cyparissias Helioscopia Ipecacuanhae

Toad-flax bastard Blue

Tobacco Indian

Tofieldia racemosa

Tomato Strawberry
772 Touch-me-not

772 Pale 807 Tovara

3 IO virginiana

Tracaulon

3 I arifolium

309 sagittatum

Tradescantia

555 reflexa virginiana

824 Tragopogon

821 porrifolius

822 pratensis

9 I I

823

Trailing Arbutus

567

566

303

204

204

55

54

910

910

668

2 I I

$6 \mathrm{I} 8$

616

387 Tick-trefoil

229

814

8 I 3

504

756

756

497

895,896

$612,613,6 I_{4}$

6 I I

616

98

205

137

I37

447

530

529

419

568

648

569

632

I2I

I2I

652
Wild Bean

$$
\text { virginicum }
$$

Triantha

racemosa

Trichostema

dichotomum

lineare

Trientalis

americana

Trifolium

agrarium

arvense

hybridum

pratense procumbens repens

Triglochin

maritima

palustris

Trillium

cernuum

erectum

grandiflorum

nivale

recurvatum

sessile

undulatum

Triosteum

aurantiacum

perfoliatum

Triphora

trianthophora

Trollius 
340

laxus

Tufted Loosestrife

Tumble Mustard Weed

Turkey-beard

Turk's-cap Lily

Turtle-head

Tussilago

Farfara

Twayblade

Twi-foil

Twin-flower

Twin-leaf

Twisted Stalk

Typha

angustifolia

latifolia

Unifolium canadense

Urtica dioica gracilis

Urticastrum divaricatum

Utricularia cornuta

gibba intermedia purpurea subulata

Uvularia grandiflora perfoliata sessilifolia

Vagnera racemosa stellata trifolia

Valeriana officinalis

Vallisneria spiralis

Veiny Pea

Venus' Looking-glass

Veratrum viride

Woodii

Verbascum Blattaria

INDEX

350
47
402
290
120
97
794

886

I60, I6I, I75, I76

I74

690

501

58,59

5
4

85

279

279

$28 \mathrm{I}$

804

957

956

959

803

88

87
89

83
84
84

721

934

225

659

$8 \mathrm{I}$

$8 \mathrm{I}$

657
Lychnites

Thapsus

Verbena

angustifolia

hastata

urticifolia

Vernonia

noveboracensis

Veronica

americana

officinalis

peregrina

serpyllifolia

verginica

Vervain, Blue

Thoroughwort

White

Vesiculina purpurea

Vetch

Carolina

Cow

Purple

Slender

Vetching

Pale

Vicia

americana

angustifolia

caroliniana

cracca

hirsuta

tetrasperma

Vincetoxicum

hirsutum

Viola

blanda

canadensis

conspersa

cucullata

eriocarpa

lanceolata

pallens

palmata

papilionacea

pedata

primulifolia

pubescens

rotundifolia

723

723

724

830

790

791

793

792

$73 \mathrm{I}$

723

814

724

959

223

219

224

226

22I

217

226

223

219

224

22 I

22 I

201

574

582

582

578

$58 \mathrm{I}$

573

574

580

577

$57 \mathrm{I}$

573

$58 \mathrm{I}$

572

579

575 


\section{INDEX}

sororia

Violet

576

Arrow-leaved

Bird's-foot

Canada

Common Blue

Dog's-tooth

Early Blue

Great Spurred

Marsh Blue

Water

White

Wood-sorrel

Wooly Blue

Yellow

Viorna

crispa

ochroleuca

Viorna

Viper's Bugloss

Virginia Cowslip

Knotweed

Snakeroot

Stonecrop

Virgin's Bower

Wake-robin

Dwarf White

Ill-scented

Nodding

Painted

Prairie

Wall Pepper

Washingtonia

Claytoni

Water Arum

Carpet

Cress

Crowfoot

Dock, Great

Fennel

Hemlock

Hemp, Salt-marsh

Hoarhound

Leaf

Lily

Lobelia

Marigold

Milfoil

Parsnip, Hemlock

Pepper, Mild

$64,65,68$

579

571

582

577

$73,74,75$

580

575

578

573

574

505

576

572,581

240

430

239

625

636

303

624

264

238

67

69

70

71

66

332

545

3 I

258

397, 948

946

262

935

$54 \mathrm{I}$

254

719,720

665

949

945

952

939

550

260

Persicaria

96 I

649

Plantain

I0

929, 960

Shield

Spearwort

$35 \mathrm{I}$

573

Weed

White Aster

Tall

White Campion

937

858

456

Clintonia

Clover

Daisy, Common

Fringed Orchis

Heath Aster

Lettuce

Mustard

Snakeroot

79
604

849

I68

863

919

398

8 II

813

Violet

Wood Aster

Wood-sorrel

White-topped Aster

Whitlow-grass

Whorled Milkweed Milkwort

Wild Basil

Bean, Trailing

Bergamot

Blue Phlox

574

854

506

856

494

704

588

757

229

775

682

Carrot

Comfrey

547

Crane's-bill

639

Elder

426

535

108

800

Ginger

Hyacinth

37

Indigo

597

Ipecac

Lettuce

917

Marjoram

764

716

Mint, American

Onion

I 10

Pea

222

Peanut

Pepper-grass

234

386

Pink

Potato Vine

Radish

Sage 
Sarsaparilla

Stonecrop

Strawberry

Sunflower

Sweet-pea

Thyme

Wormwood

Yam-root

Willow-herb

Great

Marsh

Wind-flower

Wintergreen

One-flowered

Spotted

Woodland Sunflower

Wood Aster, white

Lettuce

Lily

Nettle

Sage

Woodbine

Rough

Small

Wood-sorrel

Tall

Violet

White

Yellow

Woolly Blue Violet

Wormwood

Beach

Common

Wild

Wrack, Sea

Xanthium commune

$\mathrm{X}$ anthoxalis

cymosa
534 stricta

317 Xerophyllum

503 asphodeloides $\quad 120$

905 Xyris

595 arenicola

756 caroliniana

24

837

I32

$379,434,436,438$

435

437

$44 \mathrm{I}$

726

518

444

904

854

918

94

$28 \mathrm{I}$

772

194

195

372

505

506

373

576

836

838

8.37

943

flexuosa

25

23

Yam-root

Wild

Yarrow

Yellow Avens

Clover

Crested Orchis

Flag

Flax

Fringed Orchis

Mountain Avens

132

850

368

603

I 66

39

335

167

360

Pimpernel

Rocket

Star-grass

Thistle

Violet

Water-cress

Wood sorrel

552

403

IOI

823

572,581

397

373

Yellow-eyed Grass $\quad 22,24,25$

Yucca

filamentosa

126

Zephyranthes

Atamasco

Zizia

aurea

cordata

Zostera

marina

834 Zygadenus

372 leimanthoides
555

555

943

124

127 


\section{FINDING LIST \\ AND \\ PICTURE GLOSSARY}





\section{FINDING LIST}

\section{By Color and Flowering Season}

All the plants in the book, except the Aquatics (Nos. 92696 I) are in this list which is arranged by color and flowering season. For those who wish a quick and easy way of finding the plant in hand, the list should prove helpful.

Under each color is given the approximate flowering time, that of the central part of the area being considered standard. For points north or south of this it will be necessary to add or subtract a few days or weeks.

Under each month, the plants are separated into three habitat-preference groups-woods, moist or wet places, and fields or dry places or escapes from gardens. Many cultivated plants tend to run away from gardens into open fields or roadsides-hence the term "escapes."

The numbers under each category refer to species numbers, not to pages.

\section{White Flowers}

IN APRIL

Woods Moist or Wet Places Fields and Dry Places, or

$67 \quad$ II I

$75 \quad 315$

$512 \quad 848$

668

IN MAY

$\begin{array}{rll}71 & 501 & 317 \\ 92 & 508 & 382 \\ 338 & 510 & 390\end{array}$




\section{White Flowers}

Woods Moist or Wet Places Fields and Dry Places, or In May

$\begin{array}{lll}389 & 536 & : 391 \\ 440 & 558 & 392 \\ 441 & 589 & 573 \\ 442 & & 574 \\ 497 & & 693 \\ 500 & & \end{array}$

Escapes from Gardens

IN JUNE

\begin{tabular}{|c|c|c|c|}
\hline 514 & & $45^{8}$ & IO4 \\
\hline $5^{16}$ & II9 & $46 I$ & I 26 \\
\hline 545 & 120 & 499 & $2 \mathrm{II}$ \\
\hline 546 & 123 & 540 & 219 \\
\hline 590 & I 45 & 542 & $34 \mathrm{I}$ \\
\hline 669 & 309 & 799 & 447 \\
\hline 702 & 3II & & $45^{2}$ \\
\hline
\end{tabular}

(There is one alpine plant of mountain summits, No. 728 )

IN July

$\begin{array}{rrrrrr}339 & 487 & 490 & 660 & \text { II } 8 & 454 \\ 342 & 515 & 520 & 731 & \text { I9I } & 456 \\ 444 & 518 & 541 & 737 & 200 & 504 \\ 450 & 519 & 549 & & 451 & \end{array}$

In August

$\begin{array}{rrrlllll}143 & 7 & 21 & 718 & 917 & \text { I90 } & 384 & 810 \\ 855 & 8 & \text { I50 } & 794 & & \text { I99 } & 423 & 813 \\ 919 & \text { IO } & \text { I68 } & 812 & & 207 & 460 & 840 \\ 920 & \text { II } & \text { I8I } & 814 & & 212 & 720 & 845 \\ & \text { I3 } & \text { I } 84 & 844 & & 238 & 758 & 846\end{array}$




\section{White Flowers}

Woods Moist or Wet Places Fields and Dry Places, or In August

$$
\begin{array}{lll}
\text { I4 } & 307 & 864 \\
20 & 491 & 876
\end{array}
$$

Escapes from Gardens

301 $766 \quad 856$

In September

808

$$
\begin{aligned}
& \text { I } 49 \\
& \text { I } 5 \text { I } \\
& 858
\end{aligned}
$$

Flowering Through Several Months, Most of Them Nearly Throughout the Season

$\begin{array}{llllllll}395 & 726 & 463 & 649 & 271 & 462 & 644 & 841 \\ 455 & 81 \mathrm{II} & 539 & 7 \mathrm{I} 6 & 320 & 495 & 65 \mathrm{I} & 849 \\ 640 & & 543 & 718 & 385 & 528 & 654 & 850 \\ & & 550 & & 386 & 547 & 736 & 85 \mathrm{I} \\ & & & & 387 & 601 & 776 & 857 \\ & & & & 457 & 604 & 793 & \\ & & & & 459 & 605 & 824 & \end{array}$

IN APRIL

\section{Yellow Flowers}

\section{4 \\ $35^{8}$ \\ 559}

IN MAY

$\begin{array}{rr}88 & 329 \\ 357 & 352 \\ 572 & 356 \\ 581 & 555\end{array}$

IN JUNE

$\begin{array}{rr}96 & 353 \\ \mathbf{1 4 2} & 471 \\ & 893 \\ & 896\end{array}$

886

II 3

355

403

627

886 $\begin{array}{lll}39 & 48 \mathrm{I} & 896\end{array}$

$334 \quad 482$

$406 \quad 552$ 409894 


\section{Yellow Flowers}

Woods Moist or Wet Places Fields and Dry Places, or IN July Escapes from Gardens

$\begin{array}{rrr}486 & 24 & 375 \\ 25 & 468 \\ \text { IO3 } & 470 \\ 335 & 473 \\ 35 \text { I } & 474 \\ 368 & 477\end{array}$

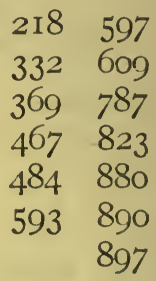

In August

710

7 I I

878

$\begin{array}{rrr}23 & 585 & 875 \\ 97 & 652 & 889 \\ 102 & 803 & 891 \\ 469 & 804 & 905 \\ 478 & 805 & 917 \\ 479 & 874 & \end{array}$

$\begin{array}{lll}23 & 585 & 875\end{array}$

$\begin{array}{lll}97 & 652 & 889\end{array}$

102803891

$478 \quad 805$ 9I7

$479 \quad 874$
IOI 399888

I96 $402 \quad 898$

$\begin{array}{lll}242 & 835 & 902\end{array}$

$\begin{array}{lll}331 & 879 & 903\end{array}$

333 88I 904

$\begin{array}{lll}376 & 883 & 924\end{array}$

$398 \quad 884 \quad 925$

(There are two alpine plants found only above timber line, Nos. 360 and $36 \mathrm{I}$ )

In September

907

330

877

882

906

Flowering Through Several Months, Most of Them Nearly Throughout the Season

$\begin{array}{lllllll}372 & 354 & 567 & 362 & 401 & 568 & 91 \mathrm{I} \\ 373 & 367 & 784 & 363 & 404 & 600 & 913 \\ 74 \mathrm{I} & 397 & 900 & 364 & 408 & 603 & 914 \\ 806 & 407 & 901 & 365 & 475 & 653 & 921 \\ & 476 & & 366 & 483 & 656 & 922 \\ & & & 400 & 554 & 733 & \end{array}$




\section{A GUIDE TO THE WILD FLOWERS}

Flowers Green, or Greenish, or Inconspicuous and Uncolored

Woods Moist or Wet Places Fields and Dry Places, or Escapes from Gardens

IN APRIL

$$
258
$$

IN MaY

$\begin{array}{rr}61 & 27 \\ 66 & 28 \\ 90 & 31 \\ 310 & 522 \\ 534 & \end{array}$

IN JUNE

62

$$
\begin{array}{r}
29 \\
30 \\
263 \\
735
\end{array}
$$

IN JULY

281

533

254

256

537

262

In August

I37

178
734

99

302

836

$$
\begin{array}{ll}
198 & 279 \\
205 & 292 \\
250 & 293 \\
251 & 305 \\
253 &
\end{array}
$$

(One alpine species, growing above timber line, No. 246) In September

$$
3^{12}
$$

285

289

834 
Flowers Green, or Greenish, or Inconspicuous and Uncolored

Woods Moist or Wet Places Fields and Dry Places, or Escapes from Gardens

Flowering Through Several Months, Most of. Them

Nearly Throughout the Season

$$
\begin{array}{ll}
269 & 283 \\
270 & 284 \\
274 & 290 \\
275 & 300 \\
276 & 818
\end{array}
$$

Flowers Greenish-yellow, Greenish-white, or Yellowish-white

IN APRIL 306

In May

87

393

$89 \quad 842$

I95 843

IN JUNE

$\begin{array}{rr}78 & 81 \\ 160 & 132 \\ 164 & 350 \\ 509 & \\ 544 & \end{array}$

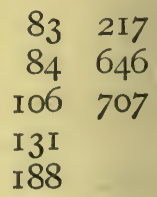

IN JULY

$\begin{array}{ll}\text { I24 } & \text { I } 28 \\ \text { I } 53 & \text { I7I } \\ \text { I55 } & \text { I79 } \\ \text { I } 72 & .185 \\ \text { I } 76 & 259\end{array}$

252

286

In August

$\begin{array}{ll}\text { I54 } & \text { I2I } \\ \text { I58 } & \text { I22 } \\ 742 & \text { I } 29\end{array}$

201

296

621 
Flowers Greenish-Yellow, Greenish-White, or Yellowish-White

Woods Moist or Wet Places Fields and Dry Places, or Escapes from Gardens

In August

$$
\begin{array}{ll}
147 & 704 \\
195 & 837
\end{array}
$$

Flowering Through Several Months, Most of Them

Nearly Throughout the Year

$$
\begin{array}{ll}
268 & 530 \\
278 & 533 \\
299 & 657 \\
394 & 817 \\
529 & 838
\end{array}
$$

Flowers Orange or Orange-Yellow

IN MAY

645

IN JUNE

I 14

194

IN JULY

94

95

98

I 5

I 82

890
In August

I66

167

697

918

923

IN JULY-OCTOBER

566

912

Flowers Brown, Greenish-brown, Greenish-purple, or Brown-purple

IN March

32

IN MAY

$\begin{array}{rr}65 & 430 \\ 344 & 800\end{array}$

$$
\text { IN JuLY }
$$

$$
\begin{array}{r}
4 \\
5 \\
700 \\
701 \\
703
\end{array}
$$


352 A GUIDE TO THE WILD FLOWERS

Woods Moist or Wet Places Fields and Dry Places, or Escapes from Gardens

In June

$$
\begin{array}{r}
58 \\
59 \\
108 \\
138 \\
624 \\
678
\end{array}
$$

In September

$$
303
$$

\section{Flowers Blue, Violet, Bluish-Violet, or Bluish-Purple} Woods Moist or Wet Places Fields and Dry Places, or

IN APRIL

$$
636
$$
Escapes from Gardens

$$
\begin{aligned}
& 136 \\
& 204 \\
& 228 \\
& 229 \\
& 236 \\
& 588 \\
& 788
\end{aligned}
$$


A GUIDE TO THE WILD FLOWERS

Flowers Blue, Violet, Bluish-Violet, or Bluishpurple

Woods Moist or Wet Places Fields and Dry Places, or Escapes from Gardens

IN August

862

$\begin{array}{rr}53 & 630 \\ \text { I } 34 & 633 \\ \text { I69 } & 663 \\ \text { I70 } & 763 \\ 436 & 777\end{array}$

$\begin{array}{lll}52 & 599 & 827\end{array}$

$\begin{array}{lll}203 & 662 & 869\end{array}$

22I $744 \quad 87$ I

$\begin{array}{lll}233 & 757 \quad 909\end{array}$

319759

In September

$\begin{array}{lllll}808 & 672 & 675 & 867 & 861 \\ 860 & 673 & 676 & 868 & 862 \\ & 674 & 829 & & 867\end{array}$

Flowering Through Several Months, Most of Them

Nearly Throughout the Season

779

$$
\begin{aligned}
& 661 \\
& 778 \\
& 782 \\
& 790
\end{aligned}
$$

(There is one alpine plant, No. 792)

$\begin{array}{llll}325 & 659 & 762\end{array}$

$\begin{array}{lll}569 & 694 & 791\end{array}$

$632 \quad 723$

64I 724

Flowers, Red, Pink, or Purple, or Variations of These Colors

IN ApriL

498

II 7

IN MAY

$\begin{array}{rrrll}69 & 505 & 527 & 223 & 68 \mathrm{I} \\ 70 & 563 & & 524 & 727 \\ \mathrm{I} 4 \mathrm{I} & 59 \mathrm{I} & & 57 \mathrm{I} & \\ 426 & & & & \end{array}$

IN JUNE

144
796

$\begin{array}{ll}\text { I } 39 & 347 \\ \text { I } 46 & 489\end{array}$

I09 595

225706 
Flowers Red, Pink, or Purple, or Variations of these Colors

Woods Moist or Wet Places Fields and Dry Places, or Escapes from Gardens

IN JUNE

In July

$$
163 \quad 626
$$

$$
\begin{array}{ll}
239 & 859 \\
241 &
\end{array}
$$

\section{56}

6 I 5

690

739

754
$260 \quad 416$

$345 \quad 432$

$346 \quad 772$

$414 \quad 895$
210

222

586

637

698

(There is one alpine species, growing above timber line, No. 247)

IN August

IIO $\quad \begin{array}{llllllll}322 & 433 & 629 & 785^{\circ} & 208 & 295 & 421 & 620\end{array}$

$\begin{array}{lllllllll}177 & 323 & 437 & 685 & 801 & 213 & 297 & 525 & 680\end{array}$

$\begin{array}{lllllllll}6 \mathrm{I} 3 & 4 \mathrm{I} 2 & 438 & 699 & 8 \mathrm{I} 5 & 2 \mathrm{I} 6 & 3 \mathrm{I} 8 & 56 \mathrm{I} & 72 \mathrm{I}\end{array}$

$\begin{array}{lllllllll}6 \mathrm{I} 4 & 4 \mathrm{I} 3 & 523 & 7 \mathrm{I} 4 & 830 & 22 \mathrm{O} & 324 & 589 & 75 \mathrm{I}\end{array}$

$\begin{array}{llllllll}616 & 417 & 587 & 750 & 230 & 326 & 612 & 760\end{array}$

$\begin{array}{llllllll}745 & 4 \mathrm{I} 8 & 6 \text { II } & 774 & 231 & 327 & 618 & 764\end{array}$

$\begin{array}{llll}234 & 378 & 619 & 832\end{array}$

In September
$684 \quad 865$
686
$826 \quad 866$
687

Flowering Through Several Months, Most of Them Nearly Throughout the Season
428
752
$\begin{array}{lllll}298 & 422 & 606 & 756 & 821\end{array}$
560
746
753
$\begin{array}{lllll}379 & 424 & 638 & 768 & 822\end{array}$
$\begin{array}{lllll}4 \text { II } & 427 & 69 I & 769 & 828\end{array}$
$\begin{array}{lllll}419 & 435 & 697 & 770 & 831\end{array}$
$\begin{array}{lll}715 & 773 & 910 \\ 775 & \end{array}$ 


\section{PICTURE GLOSSARY}

LEAVES :

Simple

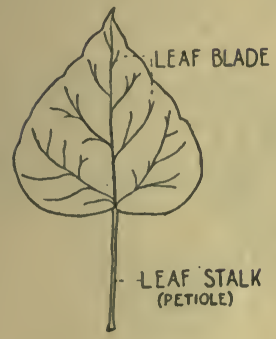

Compound.

(with several leaflets)

Compound

Feather-fashion (Pinnate)

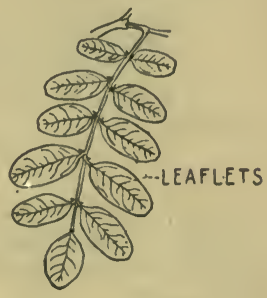

Clustered (whorled)

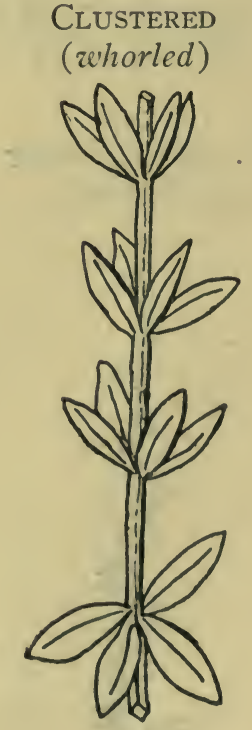

LEAF-ARRANGEMENT :

Opposite

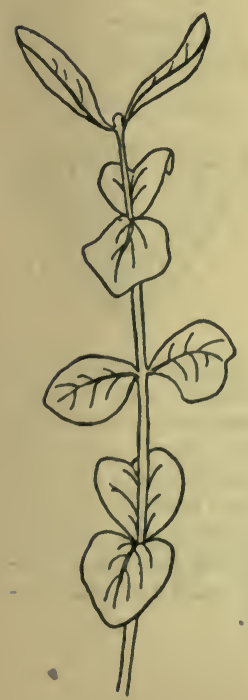

Alternate

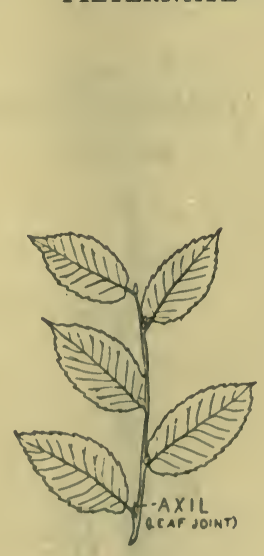

Compound

(Palmate)

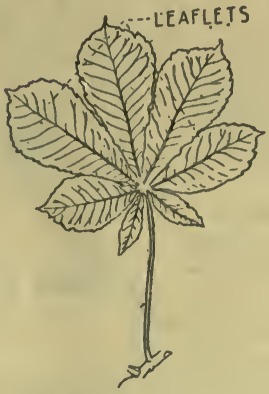




\section{FLOWERS :}

\section{A Perfect And} Complete Flower

Note: Sometimes petals are wanting. When this is true they are often replaced by colored sepals.

FLOWER CLUSTERS:

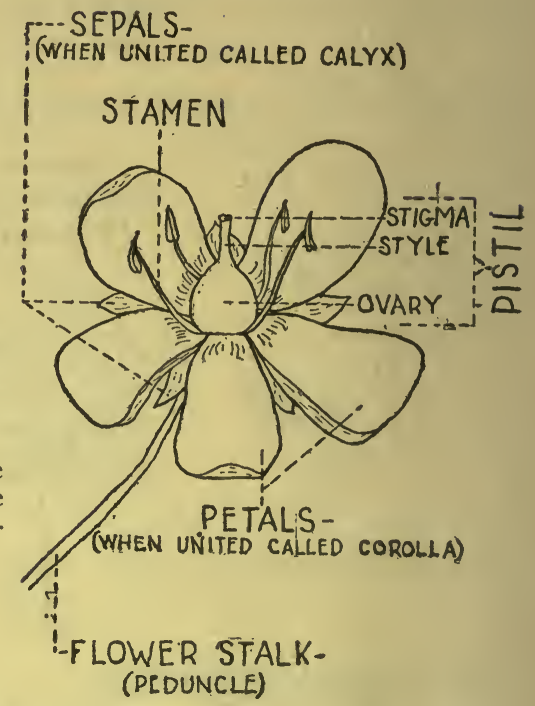

(Inflorescence)

SPIKE

(Individual flowers not stalked)

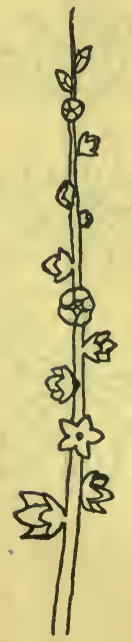

RACEME

(Individual flowers stalked)

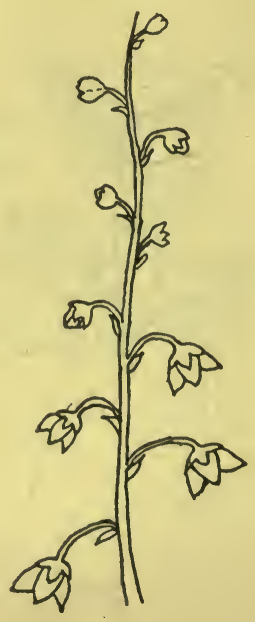

UMBEL

(See Nos. 532 and 538)

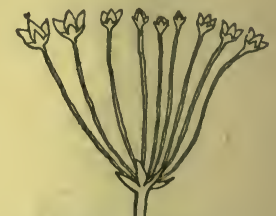

Spikes, racemes and umbels are often branched, sometimes very much so. Such ramifications of these three simple types of flower clusters have special names, omitted here for simplicity. 


\section{A GUIDE TO THE WILD FLOWERS}

JaCK-IN-The-Pulpit Family

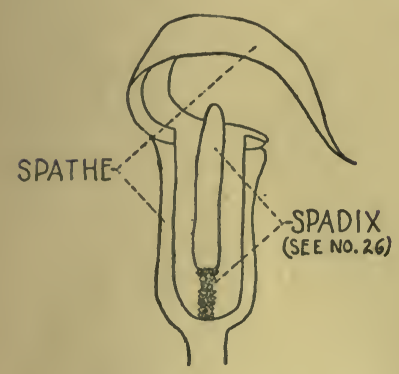

\section{SECTIONAL VIEW OF JACK-IN-THE-DULPIT}

Note: In some the spadix is not hooded by the spathe, as in this illustration, see, particularly Figs. 29 and 3 I.

\section{Daisy Family \\ (See no. 809)}

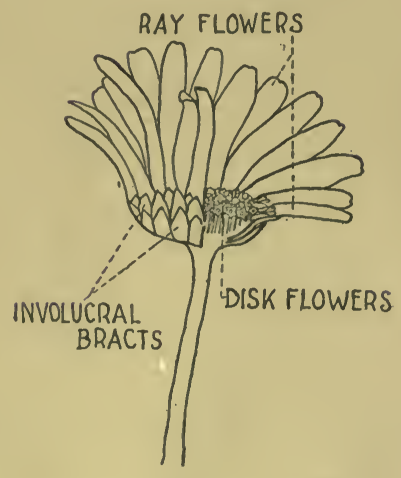

Cross section of the head of a typical plant of the Daisy Family. Some have only ray flowers, like the dandelion, others only disk flowers, like the boneset, but most have both, like the illustration. 


NEW BOOK

$$
\begin{aligned}
& \text { DOES NOT CIR- } \\
& \text { CULATE }
\end{aligned}
$$

QK TAYLOR, NORMAN

112

T2 A GUIDE TO WILD

FLOWERS

ONTARIO COLLEEE OF ART 100 MCCAUL ST.

TORONTO 2B, ONTARIO 


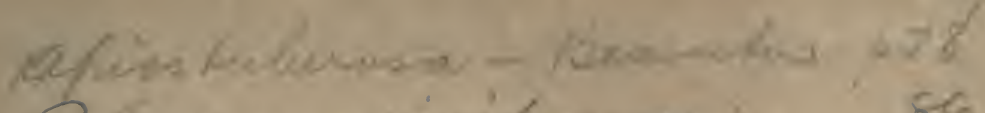

- Fyaranano cones.

105

- Sangapionba can 106 106

Urivolain courer

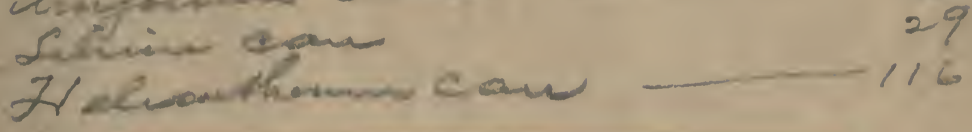

737

Taglor, Gomman

737

T. Imers 8

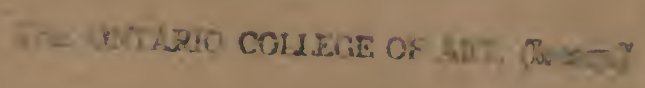


